CLAUDIANA PAULA DE SOUZA SALES

DIVERSIDADE DE BACTÉRIAS QUITINOLÍTICAS

ISOLADAS EM AMOSTRAS DE ÁGUA DO MAR E PLÂNCTON

COLETADAS NA REGIÃO COSTEIRA

DO ESTADO DE SÃO PAULO

Tese (Doutorado) apresentada ao Programa de Pós-Graduação Interunidades em Biotecnologia USP/Instituto Butantan/IPT, para obtenção do Título de Doutor em Biotecnologia.

São Paulo 


\section{DIVERSIDADE DE BACTÉRIAS QUITINOLÍTICAS ISOLADAS EM AMOSTRAS DE ÁGUA DO MAR E PLÂNCTON COLETADAS NA REGIÃO COSTEIRA DO ESTADO DE SÃO PAULO}

CLAUDIANA PAULA DE SOUZA SALES

Tese (Doutorado) apresentada ao Programa de Pós-Graduação Interunidades em Biotecnologia USP/Instituto Butantan/IPT, para obtenção do Título de Doutor em Biotecnologia.

Área de Concentração: Biotecnologia

Orientadora: Prof ${ }^{\mathrm{a}}$. Dr ${ }^{\mathrm{a}}$. Irma N. G. Rivera

São Paulo 
DADOS DE CATALOGAÇÃO NA PUBLICAÇÃO (CIP)

Serviço de Biblioteca e Informação Biomédica do

Instituto de Ciências Biomédicas da Universidade de São Paulo

(C) reprodução total

Souza-Sales, Claudiana Paula de.

Diversidade de bactérias quitinolíticas isoladas de amostras de água do mar e plâncton coletadas na região costeira do estado de São Paulo, Brasil / Claudiana Paula de Souza-Sales. -- São Paulo, 2009.

Orientador: Irma Nelly Gutierrez Rivera.

Tese (Doutorado) - Universidade de São Paulo. Instituto de Ciências Biomédicas. Programa de Pós-Graduação Interunidades em Biotecnologia USP/IPT/Instituto Butantan. Área de concentração: Biotecnologia. Linha de pesquisa: Microbiologia ambiental.

Versão do título para o inglês: Diversity of Chitinolytic Bacteria isolated from seawater and plankton samples collected at São Paulo Coast, Brazil

Descritores: 1. Bactérias quitinolíticas 2. Água do mar 3. Plâncton 4. Quitinase 5. Ecossistema marinho I. Gutierrez-Rivera, Irma Nelly II. Universidade de São Paulo. Instituto de Ciências Biomédicas.

Programa de Pós-Graduação em Biotecnologia III. Título. 


\section{UNIVERSIDADE DE SÃO PAULO \\ Programa de Pós-Graduação Interunidades em Biotecnologia}

Universidade de São Paulo, Instituto Butantan, Instituto de Pesquisas Tecnológicas

Candidato(a): $\quad$ Claudiana Paula de Souza-Sales.

Título da Tese: $\quad$ Diversidade de bactérias quitinolíticas isoladas de amostras de água do mar e plâncton coletadas na região costeira do estado de São Paulo, Brasil.

Orientador(a): Irma Nelly Gutierrez Rivera.

A Comissão Julgadora dos trabalhos de Defesa da Tese de Doutorado, em sessão pública realizada a .................., considerou

\section{$\begin{array}{ll}\text { ( ) Aprovado(a) ( ) Reprovado(a) } & \text { (a) }\end{array}$}

Examinador(a): Assinatura:

Nome:

Instituição:

Examinador(a): Assinatura:

Nome:

Instituição:

Examinador(a): Assinatura:

Nome:

Instituição:

Examinador(a): Assinatura:

Nome:

Instituição:

Presidente: Assinatura:

Nome:

Instituição: 

Aos meus pais,

José Francisco de Souza \&

Maria Maijena de Souza

Por todo o carinho, incentivo e pelo apoio constante em todos os momentos.

Com muito amor e gratidão,

DEDICO.

Ao meu esposo,

Alexandre B. de Sales

Por todo o amor, dedicação, compreensão

e por me incentivar a realizar todos os meus sonhos,

OFEREÇO. 


\section{AGRADECIMENTOS}

\section{Meus sinceros agradecimentos...}

A Deus por estar sempre do meu lado, dando me forças e esperanças para superar todos os obstáculos em minha caminhada e a Nossa Senhora por sempre interceder por mim.

À prof ${ }^{a}$ Irma N. G. Rivera pela orientação, amizade, pelos ensinamentos e paciência nestes anos de convivência. Muito obrigada por ter acreditado em mim e no meu trabalho e por me dar a oportunidade de fazer parte da sua equipe.

À Coordenação do Programa de Pós Graduação Interunidades em Biotecnologia (ICB-USP) pelos ensinamentos e oportunidades durante o curso, em especial pelos auxílios concedidos para participação de Congressos.

Aos membros da Banca de Qualificação, prof ${ }^{a}$. Dra. Luiziana Ferreira, Dra. Cristine Barreto e Cristina Nakayama pelas valiosas sugestões, críticas e elogios.

Às amigas e amigos do Laboratório de Ecologia Microbiana Molecular, Keili, Solange, Oyama, Mário, Caroline, Franklin, Renata, Bruna, Neilza, Milena, Mariana, Roberta, Helena e Lívia pela amizade e pela colaboração nesses anos de trabalho. E em especial às amigas Bianca, Mariela, Gislaine e Lílian pela amizade sincera, carinho e trocas de conhecimentos. Bianca e Mariela, muito obrigada por todos os ensinamentos, pela compreensão e por todas as horas de convívio. Saibam que, sem vocês, essa caminhada teria sido muito mais difícil.

À Dra. Cristine C. Barreto pelos ensinamentos, paciência e valiosas sugestões durante os ensaios de degradação enzimática e análises de sequências genômicas.

À prof ${ }^{a}$. Dra. Vívian H. Pellizari, prof ${ }^{a}$. Dra. Claudete R. Paula e prof ${ }^{\circ}$. Dr. René P. Schneider e aos seus alunos pela colaboração direta ou indireta na realização desse trabalho. Agradeço em especial à Emanuele Kuhn pelos ensinamentos nos últimos anos de pesquisa.

À Coordenação e funcionários do Centro de Biologia Marinha da Universidade de São Paulo, Base Clarimundo de Jesus do Instituto Oceanográfico da Universidade de São Paulo e Corpo de Bombeiros de Santos, S.P. pelo suporte para realização das coletas de amostras de água do mar e plâncton no litoral do Estado de São Paulo. 
Aos funcionários da Secretaria de Pós-Graduação Interunidades em Biotecnologia (ICB-USP), Eliane, Fábia e Marcos pelo auxílio durante todo o período desse curso.

Aos funcionários Alice, Aninha, Naíde, Irís e Sr. Luís pelo auxílio na realização desse trabalho. Especialmente à Rosa pela cooperação e apoio em todos os momentos. À Zelma um agradecimento especial pela compreensão, incentivo e apoio nesses anos de convívio.

Aos funcionários da biblioteca do Instituto de Ciências Biomédicas pela colaboração na obtenção de artigos científicos e correção das referências bibliográficas.

À Profa Sandra M. Rodrigues pelas valiosas sugestões ortográficas durante a redação desse trabalho. Ao CNPq pela bolsa de doutorado concedida e à FAPESP pelo apoio financeiro.

A todos aqueles que colaboraram e que, de alguma forma, fizeram parte desta fase da minha vida profissional e pessoal,

Muito obrigada!!!

Agradecimentos especiais...

Aos meus pais, José Francisco e Maijena pelo amor, pelo incentivo e por sempre acreditar nos meus sonhos. Obrigada por estarem sempre me apoiando e lutando para que eu alcançasse meus objetivos. Saibam que vocês são um exemplo de dedicação à família, de esforço e determinação. Papai e mamãe essa conquista não é apenas minha, é nossa !!!

Ao meu esposo Alexandre pela colaboração, pela atenção, pelo incentivo e por todo o esforço e sacrifício feito para que eu atingisse os meus objetivos!

Às minhas irmãs Regina e Michelle pelo carinho e por sempre acreditarem que essa conquista seria possível...

À Tia Lili (in memorian) por todo o incentivo, pelas lições de vida e por sempre ter torcido pelo meu sucesso!!!

Aos meus afilhados Katiane e Lucas pelo carinho e também pela compreensão por esses anos de ausência..

Ao Alcindo e a Fia pelo incentivo e por sempre estarem por perto quando precisei de ajuda! À madrinha Rita de Cássia pelo apoio, incentivo e também pelas aulas de química!!! E a todos os familiares e amigos cujos nomes não se encontram aqui, mas que, de alguma forma, contribuíram para o sucesso desse trabalho, o meu muito obrigado !!!!

E mais uma vez, obrigada meu Deus, por mais essa realização!!! 
"Cada pessoa que passa na nossa vida passa sozinha, porque cada pessoa é única e nenhuma substitui a outra. Cada pessoa que passa pela nossa vida passa sozinha, mas não nos deixa só, porque deixa um pouco de si e leva um pouquinho de nós. Essa é a mais bela responsabilidade da vida e a prova de que as pessoas não se encontram por acaso" 


\section{RESUMO}

SOUZA-SALES, C.P. Diversidade de bactérias quitinolíticas isoladas em amostras de água do mar e plâncton coletadas na região costeira do estado de São Paulo, Brasil. 2009. 204 f. Dissertação (Doutorado em Biotecnologia) - Instituto de Ciências Biomédicas, Universidade de São Paulo, São Paulo, 2009.

Bactérias quitinolíticas são autóctones em ecossistemas marinhos e tem um importante papel no processo de degradação de quitina. Essas bactérias podem ser encontradas livres ou em associação com exoesqueletos quitinosos e/ou materiais particulado presentes na coluna d'água de ambientes marinhos. Quitinases são enzimas que degradam quitina a oligossacarídeos solúveis e foram descritas em organismos dos três domínios da vida (Archaea, Bacteria e Eucarya). Bactérias quitinolíticas marinhas usam quitinases principalmente para digerir quitina como uma fonte de nutrientes e possibilitam assim a reciclagem desse polissacarídeo nos oceanos. Quitinases bacterianas têm recebido maior atenção devido às suas potenciais aplicações na agricultura, medicina e processos biotecnológicos. Relativamente pouco é conhecido sobre a diversidade e o potencial enzimático de bactérias quitinolíticas isoladas de ambientes tropicais costeiros. Amostras de água do mar e plâncton foram coletadas em três locais do litoral brasileiro: Canal de São Sebastião (Agosto/2005 a Março/2007), Baixada Santista (Fevereiro a Maio 2006 e Janeiro a Março/2007) e Ubatuba (Fevereiro a Maio 2006 e Janeiro a Março/2007), os quais apresentavam diferenças nos níveis de impacto antropogênico. As bactérias quitinolíticas foram enumeradas e isoladas em meio mínimo contendo quitina coloidal e as bactérias obtidas foram caracterizadas por métodos fenotípicos e genotípicos. Adicionalmente, em amostras de água do mar foram determinados parâmetros físico-químicos (temperatura, $\mathrm{pH}$, salinidade e condutividade) e microbiológicos (coliformes termotolerantes e enterococos intestinais). A produção de quitinases foi avaliada pela formação de zonas claras (halos) em meio mínimo contendo quitina coloidal, pela liberação de GlcNAc a partir da degradação de quitina coloidal e pela produção das enzimas $\beta$ - $N$-acetil-glicosaminidase, quitobiosidase e endoquitinase. Isolados selecionados foram caracterizados por BOX-PCR e ERIC-PCR e foram identificados em nível de gênero pelo sequenciamento do gene $16 \mathrm{~S}$ rDNA. As maiores contagens de bactérias quitinolíticas foram observadas em amostras de água do mar e plâncton coletadas na Baixada Santista. Correlações positivas foram encontradas entre as contagens de bactérias quitinolíticas e coliformes termotolerantes em amostras de água do mar coletadas no Canal de São Sebastião e Baixada Santista. Foram isolados um total de 492 bactérias quitinolíticas e os maiores valores de quitinases foram detectados em bactérias de água do mar da Baixada Santista, ambiente com alto impacto antropogênico. BOX-PCR e ERIC-PCR mostraram uma alta diversidade genética de bactérias quitinolíticas, especialmente na Baixada Santista. No entanto, houve menor diversidade de gêneros, com presença predominante de Aeromonas sp. (>78\%). Amostras de água do mar e plâncton coletadas no

Canal de São Sebastião e amostras de plâncton coletadas em Ubatuba mostraram uma ampla diversidade, abrangendo 19 gêneros pertencendo a três filos: Proteobacteria, Actinobacteria e Firmicutes. O presente trabalho mostrou que a diversidade de bactérias quitinolíticas e o potencial de produção de quitinases foi influenciado pelo nível de contaminação fecal presente no ambiente, visto que a maior diversidade foi encontrada em ambiente com médio e baixo impacto antropogênico, mas bactérias quitinolíticas isoladas de ambiente com alta atividade antropogênica mostraram os maiores valores de produção de quitinases.

Palavras-chaves: Bactérias quitinolíticas. Água do Mar. Plâncton. Quitinase. Ecossistema marinho. 


\begin{abstract}
SOUZA-SALES, C.P. Diversity of Chitinolytic Bacteria isolated from seawater and plankton samples collected São Paulo Coast, Brazil. 2009. 204 p. Ph.D. Thesis (Biotechnology) - Instituto de Ciências Biomédicas, Universidade de São Paulo, São Paulo, 2009.
\end{abstract}

Chitinolytic bacteria are autochthonous in marine ecosystems and have an important role in chitin degradation process. These bacteria can be found free-living or in association with chitinous exoskeletons and particulate detritus in the water column of marine environment. Chitinases are enzymes that degrade chitin to soluble oligosaccharides and were described in organisms belonging to three domains of life (Archaea, Bacteria and Eucarya). Marine chitinolytic bacteria use chitinases mainly to digest chitin as a nutrient source, and therefore allow the recycling of chitin in the oceans. Chitinases from bacteria have received increased attention due to their potential applications in agriculture, medicine and in biotechnology process. Relatively little is known about the diversity and enzymatic potential of chitinolytic bacteria isolated from coastal tropical environments. Seawater and plankton samples were collected from three sites at the Brazilian Coast: "Canal de São Sebastião" (August/2005 to March/2007), "Baixada Santista" (February to May/2006 and January to March/2007) and "Ubatuba" (February, March and May/2006 and January to March/2007), which showed different levels of anthropogenic impact. Chitinolytic bacteria were counted and isolated in minimal media containing colloidal chitin and characterized using phenotypic and genotypic methods. In addition, the seawater samples were evaluated for physical-chemical (temperature, $\mathrm{pH}$, salinity and conductivity) and microbiological (thermotolerant coliforms and intestinal enterococci) parameters. The chitinases production was evaluated by the formation of clearing zones (halos) on minimal media with colloidal chitin, by the release of GlcNAc from chitin and by the enzymatic production of $\beta$ - $N$-acetylglucosaminidase, chitobiosidase and endochitinase. Isolates selected were characterized by BOX-PCR and ERIC-PCR and were identified by 16S rRNA gene sequencing. The highest counts of chitinolytic bacteria were observed in seawater and plankton samples collected at "Baixada Santista". Positive correlation was found between the count of chitinolytic bacteria and thermotolerant coliforms in seawater samples collected at "Canal de São Sebastião" and "Baixada Santista". Four hundred and ninety two chitinolytic bacteria were isolated and the highest values of chitinases were found in isolates from seawater samples collected at "Baixada Santista", an environment with high anthropogenic impact. BOX-PCR and ERICPCR techniques showed high genetic diversity of chitinolytic bacteria, especially in isolates from samples collected at "Baixada Santista". However, the lower diversity of genera of chitinolytic bacteria were found in seawater and plankton samples obtained at "Baixada Santista" with high incidence of Aeromonas sp. (> 78\%). Seawater and plankton samples collected at "Canal de São Sebastião" and plankton samples collected at "Ubatuba" showed a wide diversity covering 19 genera belonging to three phylum: Proteobacteria, Actinobacteria and Firmicutes. The present work showed that the diversity of chitinolytic bacteria and the chitinases production were influenced by the level of fecal contamination present in the environment. Higher diversity was found in environment with medium and low anthropogenic impact, but the chitinolytic bacteria isolated from environment with high anthropogenic activity showed the highest values of chitinases production.

Key words: Chitinolytic Bacteria. Seawater. Plankton. Chitinase. Marine Ecossystems. 


\section{LISTA DE ILUSTRAÇÕES}

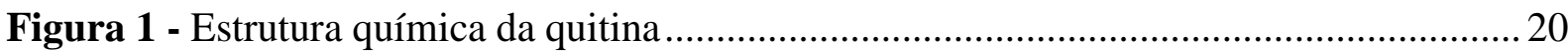

Figura 2 - Representação esquemática das três formas de quitina ........................................ 21

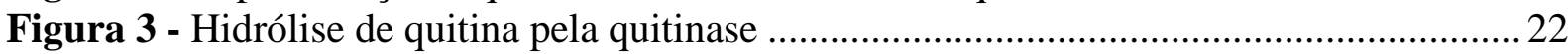

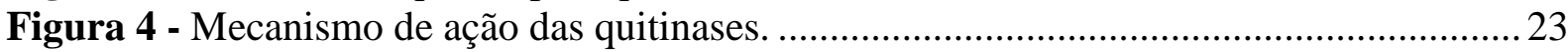

Figura 5 - Degradação de quitina por Vibrios no ambiente marinho .................................. 26

Figura 6 - Visão geral da degradação de quitina realizada por bactéria marinha..................... 28

Figura 7 - Localização dos pontos de coleta de amostras em Ubatuba, Canal de São Sebastião

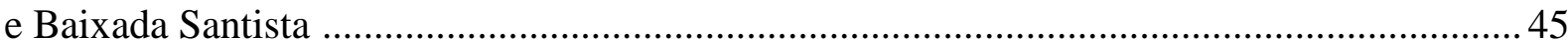

Figura 8 - Medida do halo de hidrólise de quitina produzido pelos isolados quitinolíticos em

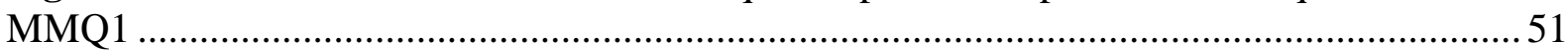

Figura 9 - Isolados quitinolíticos em MMQ1 após 96 horas de incubação a $27 \pm 2{ }^{\circ} \mathrm{C}$.......... 59

Figura 10 - Comparação das contagens de bactérias quitinolíticas em 18 amostras de água do mar e em14 amostras de plâncton utilizando os meios de culturas MMQ1 e MMQ2 ............. 60

Figura 11 - Valor da mediana, percentil 25 e 75 das contagens dos indicadores de contaminação fecal nas amostras de água do mar coletadas no Canal de São Sebastião, Baixada Santista e Ubatuba

Figura 12 - Valor da mediana, percentil 25 e 75 das contagens de bactérias quitinolíticas e CSH nas amostras de água do mar e plâncton nos dois pontos de coleta do Canal de São Sebastião

Figura 13 - Média aritmética das contagens de bactérias quitinolíticas e CSH em amostras de água e plâncton do Canal de São Sebastião

Figura 14 - Valor da mediana, percentil 25 e 75 das contagens de bactérias quitinolíticas e CSH nas amostras de água do mar e plâncton nos dois pontos de coleta de Ubatuba

Figura 15 - Média aritmética das contagens de bactérias quitinolíticas e CSH em amostras de água e plâncton de Ubatuba 68

Figura 16 - Valor da mediana, percentil 25 e 75 das contagens de bactérias quitinolíticas e CSH nas amostras de água do mar e plâncton nos três pontos de coleta da Baixada Santista 70

Figura 17 - Contagens de bactérias quitinolíticas e CSH em amostras de água do mar coletadas na Baixada Santista

Figura 18 - Média aritmética das contagens de bactérias quitinolíticas e CSH em amostras de

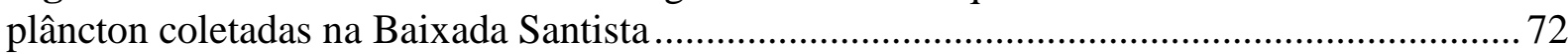

Figura 19 - Coloração de Gram de bactérias quitinolíticas .................................................... 74

Figura 20 - Frequiência de bactérias quitinolíticas gram-negativas, gram-positivas (bacilos e

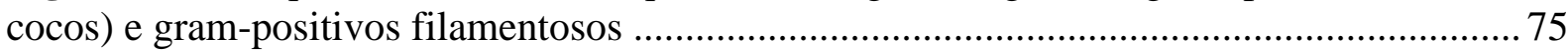

Figura 21 - Distribuição de bactérias quitinolíticas isoladas de amostras de água do mar e plâncton do Canal de São Sebastião (A), Ubatuba (B) e Baixada Santista (C), de acordo com o diâmetro do halo de hidrólise de quitina e tipo de bactéria.

Figura 22 - Valor da mediana, percentil 25 e 75 do diâmetro do halo de hidrólise de quitina produzido pelas bactérias quitinolíticas gram-negativas e gram-positivas (bacilos e cocos) após 96 horas de incubação (A e B) e pelas bactérias quitinolíticas filamentosas após 168 horas de incubação (C e D) isoladas em amostras do Canal de São Sebastião, Ubatuba e Baixada Santista......

Figura 23 - Distribuição de bactérias quitinolíticas isoladas de amostras de água do mar e plâncton, por local de coleta, de acordo com a atividade enzimática necessária para a liberação de $N$-acetil-glicosamina, a partir da degradação de quitina coloidal. 
Figura 24 - Valor da mediana, percentil 25 e 75 do diâmetro do halo de hidrólise de quitina produzido pelas bactérias quitinolíticas gram-negativas e gram-positivas (bacilos e cocos) após 96 horas de incubação (A e B) e pelas bactérias quitinolíticas filamentosas após 168 horas de incubação (C e D) isoladas em amostras do Canal de São Sebastião, Ubatuba e Baixada Santista..

Figura 25 - Distribuição de bactérias quitinolíticas isoladas de amostras de água do mar e plâncton, por local de coleta, de acordo com a produção da enzima $\beta$ - $N$-acetilglicosaminidase.

Figura 26 - Valor da mediana, percentil 25 e 75 do diâmetro do halo de hidrólise de quitina produzido pelas bactérias quitinolíticas gram-negativas e gram-positivas (bacilos e cocos) após 96 horas de incubação (A e B) e pelas bactérias quitinolíticas filamentosas após 168 horas de incubação (C e D) isoladas em amostras do Canal de São Sebastião, Ubatuba e Baixada Santista...

Figura 27 - Produção das enzimas endoquitinase, quitobiosidase e $\beta$ - $N$-acetil-glicosaminidase pelas bactérias quitinolíticas selecionadas provenientes de amostras de água do mar. .93

Figura 28 - Produção das enzimas endoquitinase, quitobiosidase e $\beta-N$-acetil-glicosaminidase pelas bactérias quitinolíticas selecionadas, provenientes de amostras de plâncton.

Figura 29 - Comparação do diâmetro de hidrólise de quitina (A e B); produção de enzimas necessárias para formar 1,0 $\mu$ mol de GlcNAc (C e D); $\beta$ - $N$-acetil-glicosaminidase $(\mathrm{E}$ e F); quitobiosidase $(\mathrm{G}$ e $\mathrm{H}$ ) e produção de endoquitinases (I e J) produzidas pelas bactérias quitinolíticas isoladas de amostras da Baixada Santista, por ponto de coleta...........................96 Figura 30 - Dendrograma construído com a técnica de BOX-PCR com bactérias quitinolíticas isoladas de amostras de água do mar do Canal de São Sebastião

Figura 31 - Dendrograma construído com a técnica de ERIC-PCR com bactérias quitinolíticas isoladas de amostras de água do mar do Canal de São Sebastião ................... 102 Figura 32 - Dendrograma construído com a técnica de BOX-PCR com bactérias quitinolíticas isoladas de amostras de plâncton do Canal de São Sebastião 105

Figura 33 - Dendrograma construído com a técnica de ERIC-PCR com bactérias quitinolíticas isoladas de amostras de plâncton do Canal de São Sebastião 106

Figura 34 - Dendrograma construído com a técnica de BOX-PCR com bactérias quitinolíticas isoladas de amostras de plâncton de Ubatuba 108

Figura 35 - Dendrograma construído com a técnica de ERIC-PCR com bactérias quitinolíticas isoladas de amostras de plâncton de Ubatuba 109

Figura 36 - Dendrograma construído com a técnica de BOX-PCR com bactérias quitinolíticas isoladas de amostras de água da Baixada Santista.

Figura 37 - Dendrograma construído com a técnica de ERIC-PCR com bactérias quitinolíticas isoladas de amostras de água da Baixada Santista....................................... 114

Figura 38 - Dendrograma construído com a técnica de BOX-PCR com bactérias quitinolíticas isoladas de amostras de Plâncton da Baixada Santista.

Figura 39 - Dendrograma construído com a técnica de ERIC-PCR com bactérias quitinolíticas isoladas de amostras de Plâncton da Baixada Santista.

Figura 40 - Diversidade de bactérias quitinolíticas em amostras de água do mar e plâncton coletadas no Canal de São Sebastião, Ubatuba e Baixada Santista.

Figura 41 - Diversidade de bactérias quitinolíticas no Canal de São Sebastião, Ubatuba e Baixada Santista

Figura 42- Diversidade de bactérias quitinolíticas no Canal de São Sebastião, Ubatuba e Baixada Santista

Figura 43 - Árvore filogenética baseada na comparação das sequiências do gene 16S rDNA das bactérias quitinolíticas pertencentes ao filo Proteobacteria com as sequiências disponíveis no RDP 
Figura 44 - Árvore filogenética baseada na comparação das sequiências do gene 16S rDNA das bactérias quitinolíticas pertencentes ao filo Firmicutes com as sequiências disponíveis no RDP 127

Figura 45 - Árvore filogenética baseada na comparação das seqüências do gene 16S rDNA das bactérias quitinolíticas pertencentes ao filo Actinobacteria com as seqüências disponíveis no RDP

Figura 46 - Dendrograma construído com a técnica de BOX-PCR com bactérias quitinolíticas identificadas pelo sequenciamento da região $16 \mathrm{~S}$ rRNA.

Figura 47 - Dendrograma construído com a técnica de ERIC-PCR com bactérias quitinolíticas identificadas pelo sequenciamento da região $16 \mathrm{~S}$ rRNA. 134 Figura 48 - Dendrograma construído com a técnica de BOX-PCR com bactérias quitinolíticas identificadas como Aeromonas sp. pelo sequenciamento da região $16 \mathrm{~S}$ rRNA 135

Figura 49 - Dendrograma construído com a técnica de ERIC-PCR com bactérias quitinolíticas identificadas como Aeromonas sp. pelo sequenciamento da região

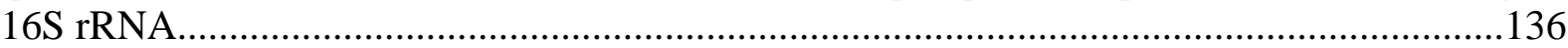




\section{LISTA DE TABELAS}

Tabela 1 - Cepas utilizadas para verificar a atividade de quitinase extracelular em meio mineral contendo quitina coloidal preparada de acordo com as metodologias 1 e 2

Tabela 2 - Iniciadores e condições de amplificação utilizada nas reações de BOX e ERIC-PCR

Tabela 3 - Comparação das três metodologias utilizadas para preparação de quitina coloidal

Tabela 4 - Valores mínimos, máximos, médias aritméticas e desvio padrão dos parâmetros físico-químicos obtidos em amostras de água do mar do litoral do estado de São Paulo ....... 61 Tabela 5 - Valores mínimos e máximos de bactérias quitinolíticas e CSH em amostras de água do mar e plâncton coletadas no Canal de São Sebastião

Tabela 6 - Valores mínimos e máximos de bactérias quitinolíticas e CSH em amostras de água do mar e plâncton coletadas em Ubatuba

Tabela 7 - Valores mínimos e máximos de bactérias quitinolíticas e CSH em amostras de água do mar e plâncton da Baixada Santista

Tabela 8 - Valores mínimos e máximos do halo de hidrólise de quitina das bactérias quitinolíticas isoladas na Baixada Santista, Canal de São Sebastião e Ubatuba

Tabela 9 - Diâmetro do halo de hidrólise de quitina produzidos por cepas padrão em MMQ1

Tabela 10 - Medida do diâmetro do halo de hidrólise de quitina e valores de produção de enzimas necessárias para formar GlcNAc e das enzimas $\beta-N$-acetil-glicosaminidase, quitobiosidase e endoquitinase produzidas pelas bactérias quitinolíticas selecionadas.......... 94 Tabela 11 - Valores de similaridades apresentadas nas técnicas de ERIC-PCR e BOX-PCR 110

Tabela 12 - Valores de similaridades apresentadas nas técnicas de ERIC-PCR e BOX-PCR 


\section{SUMÁRIO}

1 INTRODUÇÃO

2 REVISÃO DA LITERATURA ...................................................................................20

2.1 QUITINA: CARACTERÍSTICAS GERAIS ...................................................................20

2.2 QUITINASES: CARACTERÍSTICAS E FUNÇÕES NOS SERES VIVOS ..............21

2.3 A DEGRADAÇÃO BACTERIANA DE QUITINA NO AMBIENTE MARINHO....25

2.4 DIVERSIDADE DE BACTÉRIAS QUITINOLÍTICAS NO AMBIENTE

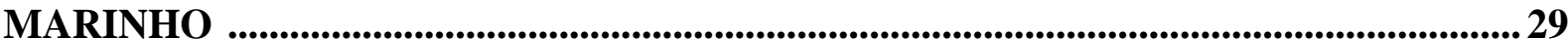

2.5 ASSOCIAÇÃO ENTRE BACTÉRIAS QUITINOLÍTICAS E ORGANISMOS

MARINHOS

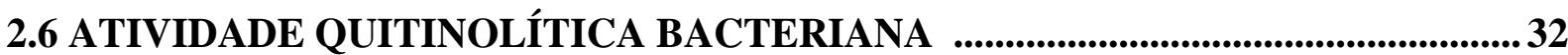

2.7 CARACTERIZAÇÃO MOLECULAR DE BACTÉRIAS QUITINOLÍTICAS .........34

2.8 APLICAÇÕES BIOTECNOLÓGICAS DAS QUITINASES ...........................................37

2.9 O AMBIENTE MARINHO BRASILEIRO ........................................................................38

2.9.1 Canal de São Sebastião .......................................................................................................39

2.9.2 Ubatuba - Saco da Ribeira .................................................................................................... 40

2.9.3 Baixada Santista ....................................................................................................................... 41

3 OBJETIVOS …………..............................................................................................43

3.1 OBJETIVO GERAL ...................................................................................................... 43

3.2 OBJETIVOS ESPECÍFICOS..........................................................................43

4 MATERIAL E MÉTODOS …......................................................................................4 4

4.2 COLETA DE AMOSTRAS .................................................................................................44

4.2.1 Período de amostragem e pontos de coleta de amostras ................................................... 44

4.2.2 Tipos de amostras coletadas .................................................................................................... 45

4.2.3 Parâmetros físico-químicos................................................................................................. 46

4.3 PADRONIZAÇÃO DO MEIO DE CULTURA PARA CRESCIMENTO DE

BACTÉRIAS QUITINOLÍTICAS..........................................................................................46

4.3.1 Seleção do método de obtenção de quitina coloidal.............................................................46

4.3.2 Preparação de Meio Mínimo (MM) ...................................................................................4 47

4.3.3 Avaliação do Meio Mínimo (MM) com quitina coloidal................................................. 47

4.3.3.1 Cepas Controle ...................................................................................................4 4

4.3.3.2 Amostras de Água do Mar e Plâncton .......................................................................48

4.4 ANÁLISES MICROBIOLÓGICAS ……............................................................49

4.4.1 Contagem em placas de bactérias quitinolíticas .............................................................49

4.4.2 Determinação da qualidade microbiológica das amostras de água do mar.............. 49

4.5 CARACTERIZAÇÃ̃O FENOTÍPICA DAS BACTÉRIAS QUITINOLÍTICAS........49

4.5.1 Reisolamento e determinação do tempo de incubação para formação de halo de

hidrólise de quitina .................................................................................................................49

4.5.2 Avaliação da degradação de quitina em meio sólido ...................................................50

4.5.3 Quantificação de atividade enzimática através da liberação de $N$-acetil-glicosamina

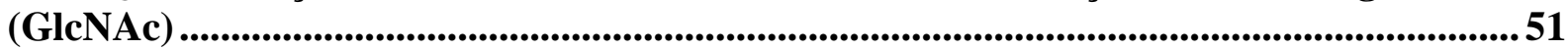

4.5.4 Quantificação de $\beta$ - $N$-acetil-glicosaminidase, Quitobiosidase e Endoquitinase .......52

4.6 CARACTERIZAÇÃO MOLECULAR DAS BACTÉRIAS QUITINOLÍTICAS ....53

4.6.1 Extração de DNA genômico …………………………........................................................53

4.6.2 Caracterização molecular pelas técnicas de ERIC-PCR e BOX-PCR ........................53

4.6.3.1 Sequenciamento parcial da região 16S rRNA................................................................54 
4.6.3.1 Amplificação parcial da região 16S rRNA das bactérias quitinolíticas ................. 54

4.6.3.2 Purificação e sequienciamento do fragmento do $16 \mathrm{~S}$ rRNA amplificado ..............55

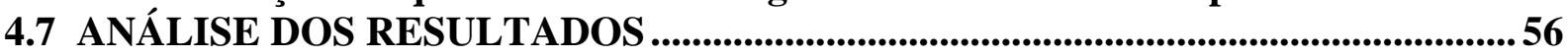

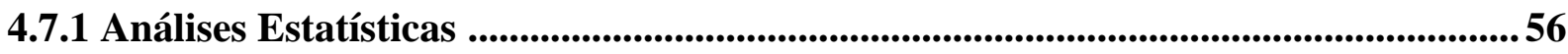

4.7.2 Análises dos agrupamentos obtidos pelas técnicas de ERIC-PCR e BOC-PCR..... 57

4.7.3 Análises das sequências obtidas pelo sequenciamento da região $16 \mathrm{~S}$ rRNA ..........57

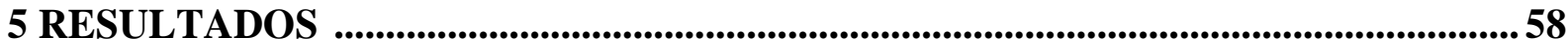

5.1 PADRONIZAÇÃO DO MEIO DE CULTURA PARA O CRESCIMENTO DE BACTÉRIAS QUITINOLÍTICAS....................................................................................58

5.1.1 Seleção do método de obtenção de quitina coloidal e preparação de Meio Mínimo (MM) ..................................................................................................................................................58 58

5.2 CARACTERIZAÇÃO FÍSICO-QUÍMICA E MICROBIOLÓGICA DOS TRÊS ECOSSISTEMAS MARINHOS ESTUDADOS .......................................................61

5.2.1 Parâmetros Físico-químicos e Indicadores de Contaminação Fecal em Amostras de Água do Mar ......................................................................................................................61 61

5.2.2 Contagem de bactérias quitinolíticas viáveis .....................................................................63 63

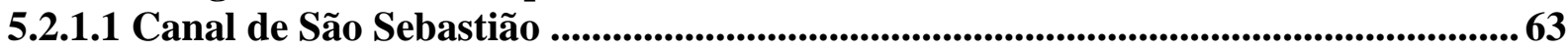

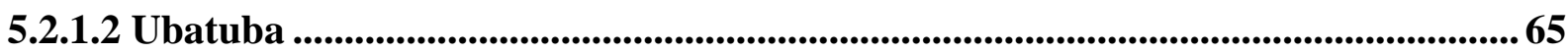

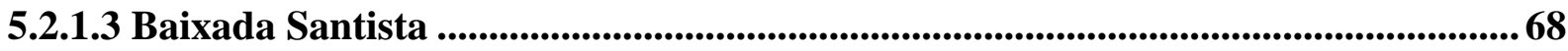

5.2.3 Comparação entre as contagens de bactérias quitinolíticas, parâmetros físicoquímicos e indicadores de contaminação fecal ........................................................................ 72

5.3 CARACTERIZAÇÃO FENOTÍPICA DAS BACTÉRIAS QUITINOLÍTICAS...... 73

5.3.1 Reisolamento e determinação do tempo de incubação para formação de halo de

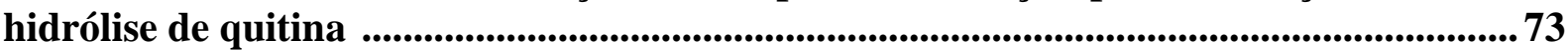

5.3.2 Avaliação da degradação de quitina em meio sólido..............................................76

5.3.3 Quantificação de atividade enzimática através da liberação de $N$-acetil-glicosamina (GlcNAc). 81

5.3.4 Quantificação da enzima $\beta$ - $N$-acetil-glicosaminidase produzida pelas bactérias

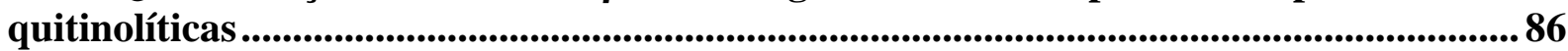

5.3.5 Quantificação das enzimas quitobiosidase e endoquitinase produzidas pelas bactérias quitinolíticas ...................................................................................................................91 91

5.4 CARACTERIZAÇÃO MOLECULAR DAS BACTÉRIAS QUITINOLÍTICAS .... 97

5.4.1 Extração de DNA genômico ................................................................................99

5.4.2 Caracterização molecular pelas técnicas de BOX-PCR e ERIC-PCR ....................98

5.4.2.1 Canal de São Sebastião ....................................................................................99

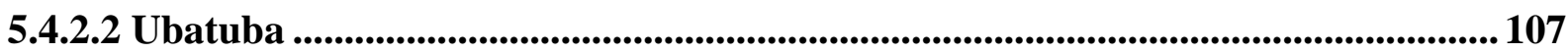

5.4.2.3 Baixada Santista .............................................................................................. 109

5.4.3 Sequenciamento parcial da região 16S rRNA ................................................ 120

5.4.4 Comparação entre as técnicas de rep-PCR, seqüienciamento parcial da região $16 \mathrm{~S}$ rRNA das bactérias quitinolíticas e atividade enzimática ..............................................129

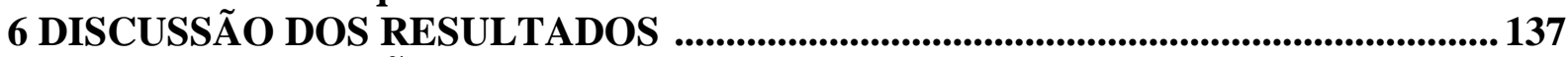

6.1 PADRONIZAÇÃO DO MEIO DE CULTURA PARA O CRESCIMENTO DE BACTÉRIAS QUITINOLÍTICAS............................................................................137

5.1.1 Seleção do método de obtenção de quitina coloidal e preparação de Meio Mínimo

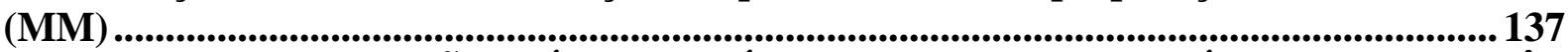
6.2 CARACTERIZAÇÃO FÍSICO-QUÍMICA E MICROBIOLÓGICA DOS TRÊS ECOSSISTEMAS MARINHOS ESTUDADOS ..............................................................138

6.2.1 Parâmetros Físico-químicos ...............................................................................138

6.2.2 Parâmetros microbiológicos - Indicadores de Contaminação Fecal ........................140

6.2.3 Contagem de bactérias quitinolíticas viáveis ....................................................142 
6.3 CARACTERIZAÇÃO FENOTÍPICA DAS BACTÉRIAS QUITINOLÍTICAS ....147 6.3.1 Reisolamento e determinação do tempo de incubação para formação de halo de hidrólise de quitina ....................................................................................................................................147

6.3.2 Avaliação da degradação de quitina em meio sólido..............................................149

6.3.3 Quantificação de atividade enzimática através da liberação de $N$-acetil-glicosamina (GlcNAc). 152 6.3.4 Quantificação da enzima $\beta$ - $N$-acetil-glicosaminidase produzida pelas bactérias quitinolíticas ..........................................................................................................................154 6.3.5 Quantificação das enzimas quitobiosidase e endoquitinase produzidas pelas bactérias quitinolíticas ................................................................................................................... 156 6.4 CARACTERIZAÇÃO MOLECULAR DAS BACTÉRIAS QUITINOLÍTICAS .. 159 6.4.1 Caracterização molecular pelas técnicas de ERIC-PCR e BOX-PCR ................... 159 6.4.2 Seqüenciamento parcial da região 16S rRNA das bactérias quitinolíticas ...........161

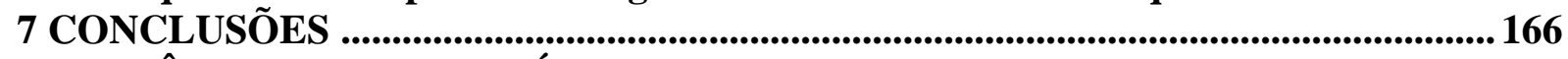

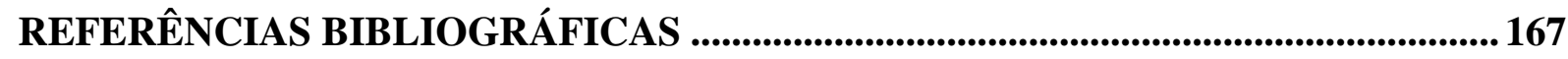

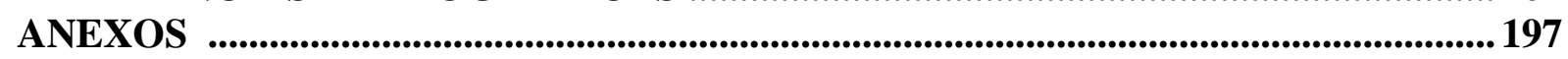




\section{INTRODUÇÃO}

Os microrganismos presentes no ecossistema marinho desempenham funções essenciais para a sobrevivência de todos os organismos vivos existentes no nosso planeta. Dentre esses microrganismos, as bactérias quitinolíticas são de fundamental importância nos processos de ciclagem de nutrientes liberando carbono e nitrogênio para toda a cadeia trófica, a partir da degradação da quitina, que é o mais abundante polímero biodegradável encontrado nos oceanos (GOODAY, 1990).

A degradação da quitina é realizada por uma enzima denominada quitinase, a qual já foi descrita em membros dos três Domínios da árvore da vida (Bacteria, Archaea e Eukarya). Em cada organismo a quitinase é utilizada em uma função distinta. As bactérias, por exemplo, entre outras funções, empregam a quitinase no processo de degradação de quitina para utilizála como fonte de carbono e energia e, consequentemente, possibilitam a reciclagem de quitina na natureza (SVITIL et al., 1997; WANG et al., 1997; ZOBELL e RITTENBERG, 1938).

Nos últimos anos, as quitinases se tornaram objeto de inúmeras pesquisas devido à ampla possibilidade de aplicação dessas enzimas como agentes de biocontrole contra fungos e insetos, produção de quito - oligossacarídeos, produção de medicamentos e conversão da quitina proveniente das indústrias de alimentos marinhos em produtos de alto valor agregado (KUMAR, 2000; RINAUDO, 2006; SHAHIDI et al., 1999).

Algumas espécies de bactérias quitinolíticas têm sido encontradas com maior frequência no ecossistema marinho, dentre as quais podemos citar: Vibrio furnissi (BASSLER et al., 1991; KEYANI e ROSEMAN, 1999), Vibrio harveyi (SVITIL et al., 1997), Vibrio anguillarum e Vibrio parahaemolyticus (HIRONO et al., 1998), Salinivibrio costicola (AUNPAD e PANBANGRED, 2003), Microbulbifer degradans (HOWARD et al., 2003b), Vibrio cholerae (LI e ROSEMAN, 2004), Vibrio proteolyticus (ITOI et al., 2007), Vibrio alginolyticus (SUGINTA, 2007), Streptomyces sp. (HAN et al., 2009) e Moritella marina (STEFANIDI e VORGIAS, 2008).

Estudos sobre diversidade de bactérias quitinolíticas em amostras ambientais vêm sendo realizados com sucesso no decorrer dos anos em alguns países, como Estados Unidos, Japão, China e Índia (BOYER, 1994; FUKASAWA et al., 1992; HAN et al., 2009; HERWIG et al., 1988; HIRANO et al., 1991; HOOD e MEYERS, 1977; RAMAIAH et al., 2000). No entanto, no Brasil os estudos sobre biodiversidade microbiana marinha têm enfocado somente a diversidade de bactérias heterotróficas em geral (ABREU et al., 1992; FONTES e ABREU, 
2009; GONZALEZ et al., 2006; KOLM e ANDRETTA, 2003; PARANHOS et al., 2001; REIS et al., 2009; VIEIRA et al., 2008) e assim, estudos sobre diversidade de bactérias quitinolíticas em diferentes áreas costeiras não têm sido encontrados.

Diante disso, considerando-se a importância das bactérias quitinolíticas para a sobrevivência de toda a cadeia trófica marinha, a ausência de trabalhos científicos sobre diversidade dessas bactérias no ecossistema aquático brasileiro, a ampla utilização de enzimas quitinolíticas bacterianas em processos biotecnológicos e sabendo que é no ambiente marinho que existe a maior reserva de quitina, a qual é rapidamente degradada pela ação microbiana, o nosso trabalho visa conhecer a diversidade de bactérias quitinolíticas em três ecossistemas marinhos com diferentes níveis de impactos antropogênicos e em dois tipos de amostras: água e plâncton e ainda avaliar o potencial enzimático dessas bactérias. 


\section{REVISÃO DA LITERATURA}

\subsection{QUITINA: CARACTERÍSTICAS GERAIS}

A quitina é um polissacarídeo formado por resíduos de $\beta$-1,4 - $N$-acetil-D-glicosamina (GlcNAc) e apresenta uma estrutura cristalina altamente ordenada (Figura 1), podendo ser encontrada na natureza em três formas distintas denominadas alfa-quitina ( $\alpha$-quitina), betaquitina ( $\beta$-quitina) e gama-quitina ( $\gamma$-quitina) (HACKMAN e GOLDBERG, 1965).

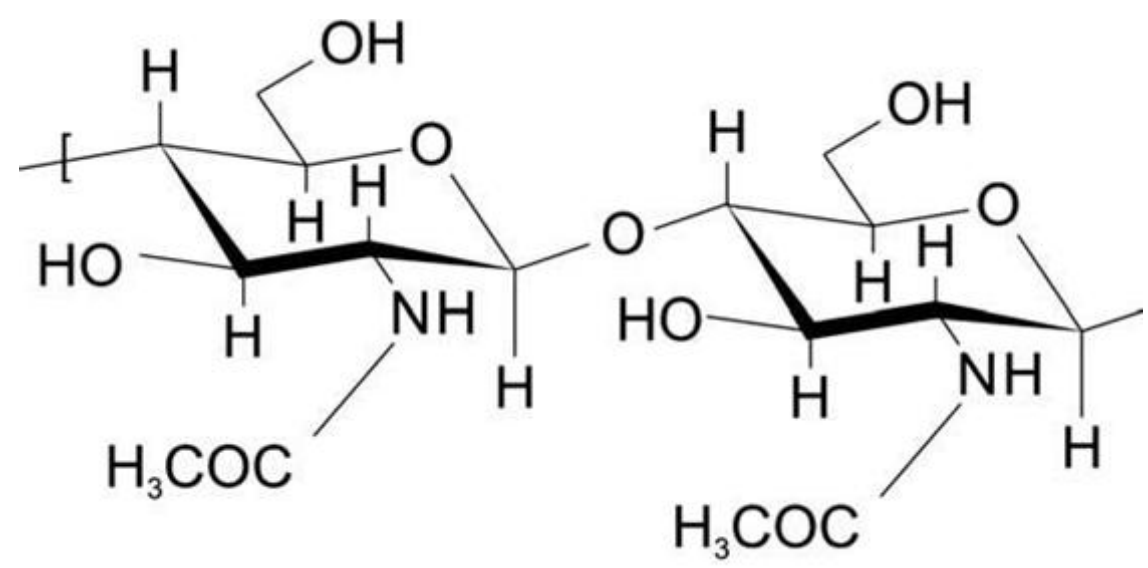

Figura 1 - Estrutura química da quitina.

FONTE: MORGANTI, P. e MORGANTI, G. 2008.

A $\alpha$-quitina é a forma mais comum existente na natureza. Ela é constituída por cadeias arranjadas de forma antiparalela (Figura 2) (CARLSTROM, 1957). Ocorre fortemente associada a proteínas, materiais inorgânicos ou ambos e está presente em estruturas rígidas e resistentes como a cutícula de artrópodes (RUDALL e KENCHING, 1973).

A $\beta$-quitina ocorre em espinhos e cerdas de alguns anelídeos, em tubos de poliquetos, na concha interna de lulas e na carapaça de algumas diatomáceas (BLACKWELL et al., 1967; BLACKWELL e WEIH, 1984; HERTH et al., 1986). Esse tipo de quitina é organizada em cadeias paralelas (Figura 2) possibilitando a formação de ligações intermoleculares mais fracas, o que propicia uma menor estabilidade dessa molécula em comparação com a $\alpha$ quitina (KURITA, 2001).

A forma mais rara presente na natureza é a $\gamma$-quitina, a qual apresenta uma mistura de $\alpha$ e $\beta$-quitina, isto é: duas de três cadeias são organizadas de forma paralela e a terceira aparece na direção oposta (Figura 2) (RUDALL e KENCHING, 1973). A $\gamma$-quitina é 
encontrada em casulos de dois gêneros de besouros e no revestimento do estômago de lulas (MUZZARELLI, 1977).

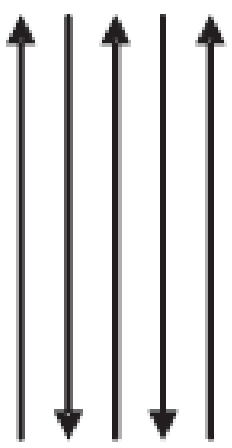

$\alpha$-quitina

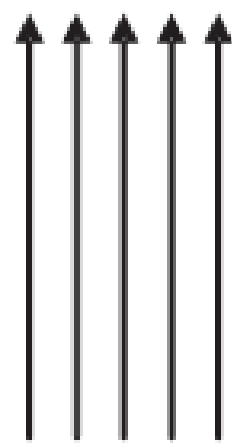

$\beta$-quitina

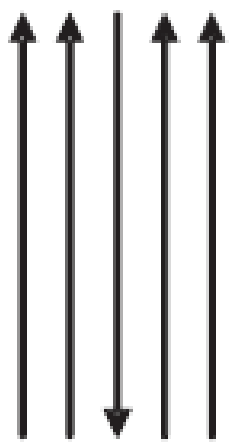

$\gamma$-quitina

Figura 2 - Representação esquemática das três formas de quitina.

FONTE: EINBU, 2007.

A distribuição dos três tipos de quitina nos organismos vivos não está relacionada à taxonomia, visto que diferentes formas podem ocorrer em um único organismo, fornecendo assim propriedades funcionais diferentes (RUDALL e KENCHING, 1973). Um exemplo pode ser observado nas lulas do gênero Loligo, onde a $\alpha$-quitina constitui uma fina capa que reveste as paredes do esôfago e do estômago, a $\beta$-quitina ocorre como o principal componente dos gládios e a $\gamma$-quitina integra uma espessa cutícula que recobre outras zonas do estômago (ROBERTS, 1992).

\subsection{QUITINASES: CARACTERÍSTICAS E FUNÇÕES NOS SERES VIVOS}

Os organismos que apresentam quitina em sua constituição estrutural também produzem quitinase, uma enzima que cliva a ligação entre o $\mathrm{C} 1$ e o $\mathrm{C} 4$ de duas $N$-acetil-Dglicosaminas (GlcNAc) consecutivas (Figura 3). No entanto, outros organismos e microrganismos com ausência de quitina também são capazes de produzir quitinase (CLARKE e TRACEY, 1956). 

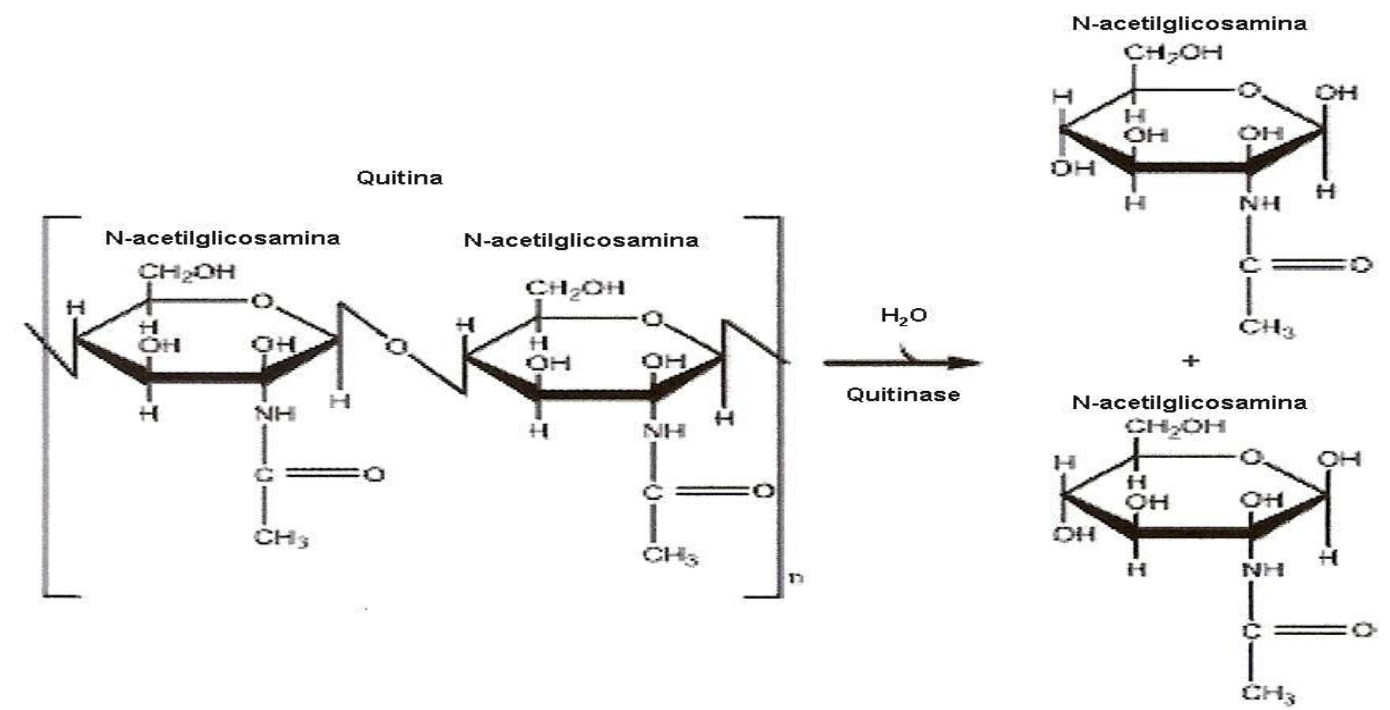

Figura 3 - Hidrólise de quitina pela quitinase.

FONTE: FLEURI e SATO, 2005.

As quitinases estão agrupadas dentro das famílias 18 e 19 do sistema de classificação das glicosil hidrolases. Quitinases da família 18 são subdivididas nos grupos A, B e C e são encontradas em bactérias, fungos, leveduras, vírus, plantas e animais. A família 19 incluía, inicialmente, apenas quitinases presentes em plantas. Porém, atualmente, sabe-se que elas também estão presentes em espécies de bactérias do gênero Streptomyces (HENRISSAT, 1991; HENRISSAT e BAIROCH, 1993; OHNO et al., 1996; SUZUKI et al., 1999).

Baseando-se nos produtos de hidrólise de quitina, as quitinases podem ser classificadas em duas grandes categorias: Endoquitinases (EC 3.2.1.14) e Exoquitinases. As exoquitinases podem ser divididas em duas subcategorias, (i) quitobiosidases e (ii) 1-4- $\beta-N$ acetil-glicosaminidases (EC 3.2.1.52) (COHEN-KUPIEC e CHET, 1998; DEANE et al., 1998; NOMENCLATURE COMMITTEE OF INTERNATIONAL UNION OF BIOCHEMSTRY AND MOLECULAR BIOLOGY, 1992).

As endoquitinases clivam aleatoriamente a molécula de quitina liberando oligossacarídeos como quitotetrose, quitotriose e quitobiose. As quitobiosidases liberam somente diacetilquitobioses (dímeros de $N$-acetil-glicosamina) de uma forma progressiva a partir da extremidade não redutora do polímero de quitina, enquanto que, as 1-4- $\beta-N$-acetilglicosaminidases clivam os oligossacarídeos produzidos pelas endoquitinases e quitobiosidades, gerando monômeros de $N$-acetil-glicosamina (GlcNAc) (COHEN-KUPIEC e CHET, 1998; HARMAN et al., 1993; SAHAI e MANOCHA, 1993) (Figura 4). 

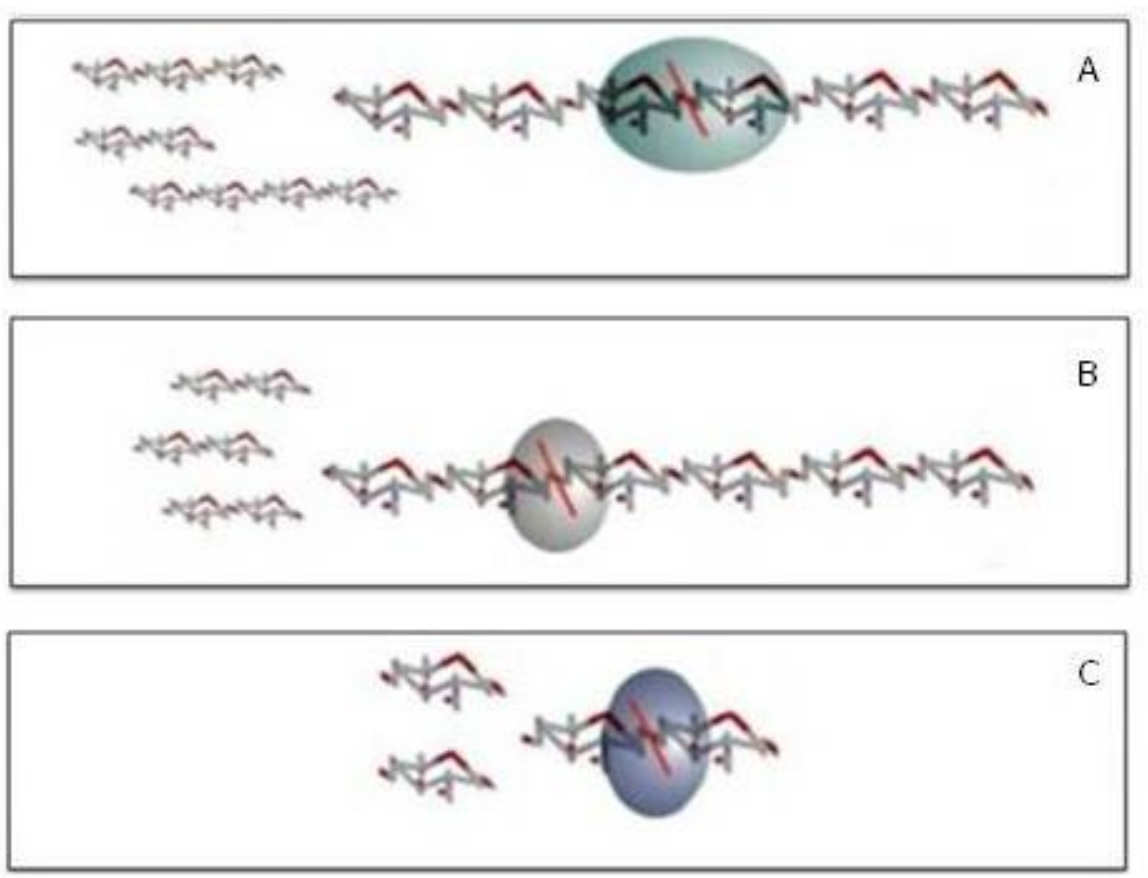

Figura 4 - Mecanismo de ação das quitinases. A: Endoquitinases; B: Quitobiosidases; C: 1-4- $\beta$ - $N$-acetilglicosaminidases.

FONTE: SILVA, 2007.

A quitinase foi descrita pela primeira vez em 1911 por Bernard em bulbos de orquídeas (BERNARD, 1911). Em 1929, Karrer e Hofmann descobriram essa enzima em caracóis (KARRER e HOFMANN, 1929) e após essa data, o número de trabalhos descrevendo a presença de quitinase em seres vivos cresceu consideravelmente, sendo que atualmente as quitinases já foram identificadas nos Domínios Bacteria, Archaea e Eukarya (BENTON, 1935; BHATTACHARYA et al., 2007; BOOT et al., 2001; TANAKA et al., 2001; ZOBELL e RITTENBERG, 1938).

As bactérias empregam a quitinase no processo de degradação de quitina para utilizála como fonte de carbono e energia e, consequentemente, possibilitam a reciclagem de quitina na natureza (SVITIL et al., 1997; WANG et al., 1997; ZOBELL e RITTENBERG, 1938). Alguns estudos têm demonstrado a ligação entre enzimas quitinolíticas e patogenicidade em uma ampla variedade de bactérias causadoras de doenças em insetos (FLYG e BOMAN, 1988; LYSENKO, 1976; SAMPSON e GOODAY, 1998). E, bactérias pertencentes aos gêneros Vibrio, Aeromonas, Pseudomonas, Alteromonas, Flavobacterium, Spirillum, Moraxella, Pasteurella e Photobacterium foram descritas como prováveis agentes causadores de doença em crustáceos marinhos (GETCHELL, 1989; VOGAN et al., 2008). 
Em fungos, as quitinases são utilizadas nos processos nutricionais, autolíticos e morfogenéticos (ADAMS, 2004). Nos artrópodes, essas enzimas estão associadas com o desenvolvimento pós-embrionário e degradação da carapaça velha de quitina (MERZENDORFER e ZIMOCH, 2003) e, em plantas, as quitinases estão envolvidas nos mecanismos de defesa, principalmente contra fungos patogênicos (GRAHAM e STICKLEN, 1994).

As quitinases produzidas por alguns tipos de vírus, como por exemplo, os baculovírus, que compreendem o maior grupo de vírus de insetos, ajudam na penetração da membrana peritrófica dos insetos e na liberação dos vírus após a morte do inseto hospedeiro (GOODAY, 1995).

A presença de quitinase já foi verificada em algumas espécies de protozoários do gênero Plasmodium (GIANSANTI et al., 2007), Leishmania (ROGERS et al., 2008; SHAKARIAN e DWYER, 1998), Trichomonas (LOISEAU et al., 2002) e Entamoeba (GHOSH et al., 1999; VEGA, et al., 1997). Plasmodium falciparum e algumas espécies do gênero Leishmania, agentes causadores da malária e da leishmaniose, respectivamente, utilizam a quitinase para digerir a membrana peritrófica de insetos durante o processo de migração do intestino médio para as glândulas salivares (ROGERS et al., 2008; SACKS e KAMHAWI, 2001; SHAHABUDDIN e KASLOW, 1994).

Os animais vertebrados não são capazes de produzir quitina. No entanto, a presença de quitinase tem sido verificada em muitas espécies, podendo ser encontrada em vários órgãos e tecidos como, por exemplo, no trato digestivo participando do metabolismo de carboidratos (HARTL et al., 2009; JEUNIAUX, 1993; OVERDIJK et al., 1996). As quitinases em mamíferos não haviam sido relatadas até 1994, quando Hollak et al. (1994) estudando pacientes com a Doença de Gaucher identificaram a quitotriosidase, a primeira quitinase humana. Em 2001, Boot et al. identificaram no trato gastrintestinal e nos pulmões de humanos outra quitinase denominada AMCase (acidic mammalian chitinase) e sugeriram que as quitinases presentes em mamíferos e humanos são responsáveis pela metabolização de carboidratos e por mecanismos de defesa contra agentes patogênicos. 


\subsection{A DEGRADAÇÃO BACTERIANA DE QUITINA NO AMBIENTE MARINHO}

A quitina é o segundo polissacarídeo encontrado em maior quantidade no planeta Terra. Porém no ambiente marinho é o biopolímero mais abundante. Esse polissacarídeo faz parte da parede celular de fungos e de certas algas verdes e é o maior constituinte do exoesqueleto de artrópodes e moluscos, fornecendo a esses organismos suporte estrutural e proteção (GOODAY, 1990).

No início do século XX foi reconhecida a importância ecológica da quitina no ambiente marinho, quando Johnstone (1908) afirmou que as águas oceânicas poderiam ter sua reserva de carbono e nitrogênio totalmente esgotada em um curto espaço de tempo se as formas insolúveis de quitina não retornassem ao ecossistema em formas biologicamente utilizáveis, visto que esses dois elementos químicos são geralmente limitados no ecossistema marinho.

A produção anual de quitina no oceano é estimada em $10^{9}$ (GOFFINET, 1996) até $10^{11}$ toneladas métricas (TRACEY, 1957) e a maior parte dessa produção é na forma de carapaças de zooplâncton (JEUNIAUX e GOODAY, 1986). Os copépodes, subclasse mais frequente do zooplâncton marinho, produzem bilhões de toneladas desse polissacarídeo anualmente, resultando em uma contínua "chuva de quitina" no oceano. Porém, mesmo com a constante liberação de quitina na coluna d'água, são encontrados somente vestígios desse polissacarídeo nos sedimentos oceânicos (ALLDREDGE e GOTSCHALK, 1990; POULICEK, e JEAUNIAUX, 1988).

Em 1937, descobriu-se que as bactérias quitinolíticas são autóctones no ambiente marinho e são responsáveis pela rápida degradação de quitina na coluna d’água, explicando assim a baixa concentração desse polissacarídeo no sedimento oceânico (KIRCHNER, 1995; ZOBELL e RITTENBERG, 1938). Essas bactérias convertem a quitina em compostos orgânicos que podem ser usados como fontes de carbono e nitrogênio por toda a cadeia trófica marinha (KEYHANI e ROSEMAN, 1999).

Keyhani e Roseman (1999) analisaram o processo de degradação de quitina realizado por Vibrio furnissi, a partir do momento em que a carapaça do zooplâncton é liberada através do processo de ecdise (muda) até a captação dos produtos da hidrólise da quitina. Os autores verificaram que esse processo envolve no mínimo quatro etapas: (1) percepção da presença de quitina por colisão ao acaso ou quimiotaxia; (2) ligação à quitina; (3) expressão de enzimas 
necessárias para degradação do polímero; e finalmente (4) captação e utilização dos produtos da hidrólise de quitina (Figura 5).

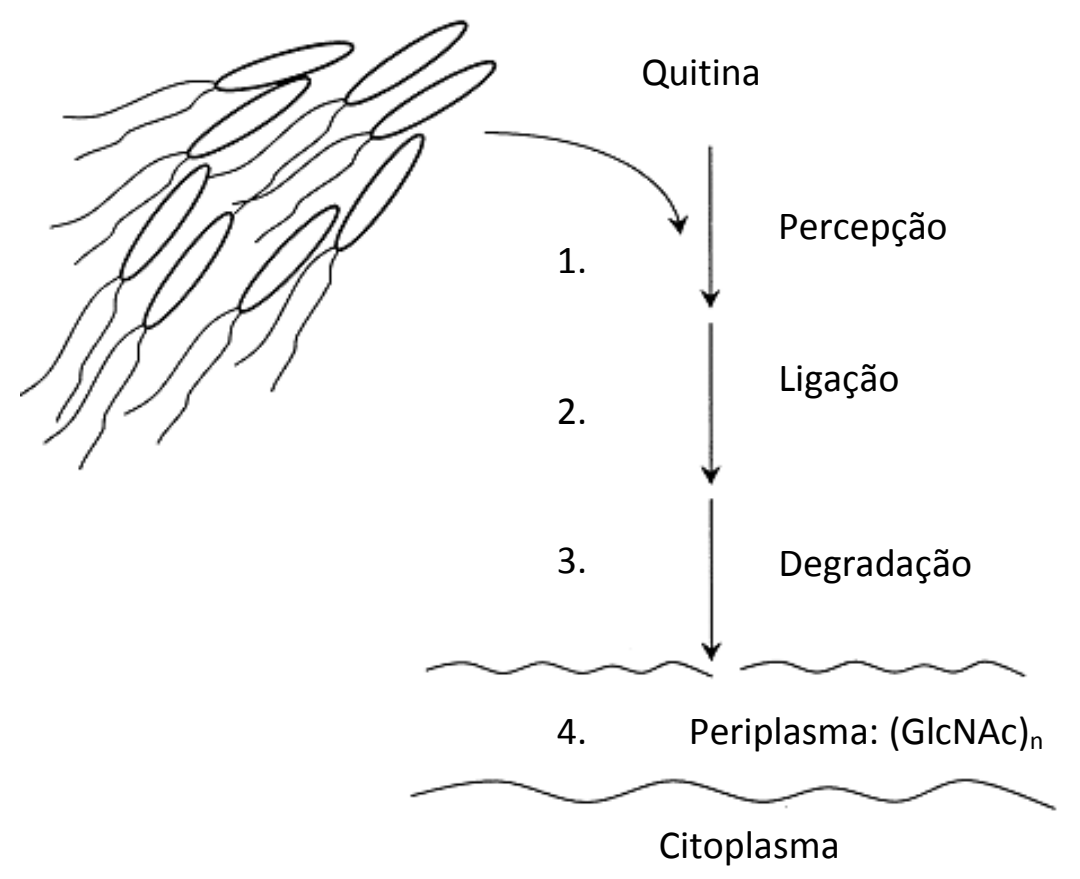

Figura 5 - Degradação de quitina por Vibrios no ambiente marinho.

FONTE: Adaptado de KEYHANI e ROSEMAN, 1999.

A primeira possibilidade para uma bactéria encontrar a fonte de alimento, no caso a quitina, seria por um processo passivo, como por colisão ao acaso. No entanto, simulações realizadas com um grupo de bactérias marinhas móveis ao redor de células planctônicas em um nível de turbulência variando de moderado a alto, em um ecossistema aquático artificial, mostraram que bactérias quimiotáticas tiveram vantagem significante sobre as bactérias nãoquimiotáticas em relação ao acesso à fonte de nutriente, fato esse, que reduz a probabilidade de colisão ao acaso (BOWEN et al., 1993; JACKSON, 1989; KEYHANI e ROSEMAN, 1999). Keyhani e Roseman (1999) sugerem então, que a quimiotaxia em bactérias que degradam quitina possibilita uma busca mais eficiente desse polissacarídeo no ambiente aquático.

Li e Roseman (2004) forneceram uma visão detalhada dos mecanismos moleculares que permitem que bactérias como $V$. cholerae e $V$. furnissi se adaptem à presença ou ausência de quitina no ambiente. Segundo os autores, a presença de (GlcNAc) $)_{n}$ é o "sinal indutor" para que as bactérias expressem uma série de genes catabólicos (chitin catabolic cascade genes) 
que são essenciais no processo de degradação de quitina. E, a partir do momento em que toda a quitina presente no ambiente é completamente utilizada, esse sistema é desligado.

A ligação bacteriana a substratos contendo quitina pode ocorrer de forma específica ou não-específica. $\mathrm{Na}$ aderência específica, a bactéria produz proteínas receptoras com especificidade para um conjunto particular de ligantes, como os carboidratos. Esse tipo de ligação frequentemente envolve proteínas presentes nas fímbrias (fimbrial proteins) ou adesinas encontradas nas extremidades do pilus o qual reconhece e liga a bactéria à superfície contendo o carboidrato (MIRELMAN, 1986). A ligação não-específica resulta em uma adesão via interações hidrofóbicas e iônicas (HEILMANN et al., 1996). Esses tipos de interações levam à formação de biofilmes contendo uma mistura de populações microbianas (KEYHANI e ROSEMAN, 1999).

Após a associação bacteriana ao substrato quitinoso é iniciado o processo de degradação de quitina, o qual envolve uma série de passos enzimáticos envolvendo quitinases extracelulares que, de forma sequencial degradam o polímero de quitina em oligossacarídeos solúveis [(GlcNAC) $)_{n}$ (COHEN-KUPIEC e CHET, 1998; HARMAN et al., 1993; KEYANI e ROSEMAN, 1999; LI e ROSEMAN, 2004; SAHAI e MANOCHA, 1993).

A Figura 6 mostra, de forma simplificada, essas três primeiras etapas do processo de degradação de quitina realizado por $V$. furnissi. Na figura, duas cutículas de quitina são representadas no quadro A. A bactéria se liga a uma dessas cutículas, cresce, multiplica-se e a digere. As células ficam agora privadas do alimento e começam a "sentir fome" (begin to starve). A partir desse momento, as bactérias precisam localizar a próxima cutícula e, aparentemente, a produção de quitinases e sua ocorrência na coluna d'água a várias concentrações tem um importante papel na localização da próxima cutícula. Uma hipótese é que quitinases endógenas produzidas durante vários estágios da vida de organismos que possuem quitina (ex.: ecdise) resultaria na liberação de oligossacarídeos de quitina. Outra possibilidade seria a secreção de quitinases extracelulares pelas bactérias que estão "sentindo fome" (Ver letra C na figura 6). Essas enzimas solúveis se espalham para longe das células e poucas moléculas de enzimas (C) começam a digerir a quitina, formando um gradiente de $(\text { GlcNAc) })_{2}$. Esse gradiente atrai as células "famintas" através do mecanismo de quimiotaxia e finalmente as células encontram a segunda quitina e o processo de degradação se inicia novamente. Os autores propõem ainda, que a quitinase extracelular pode ter duas funções: uma é fornecer o nutriente (GlcNAc) $)_{2}$ e outra é criar um caminho quimiotático para a nova fonte de quitina (KEYHANI e ROSEMAN, 1999). 


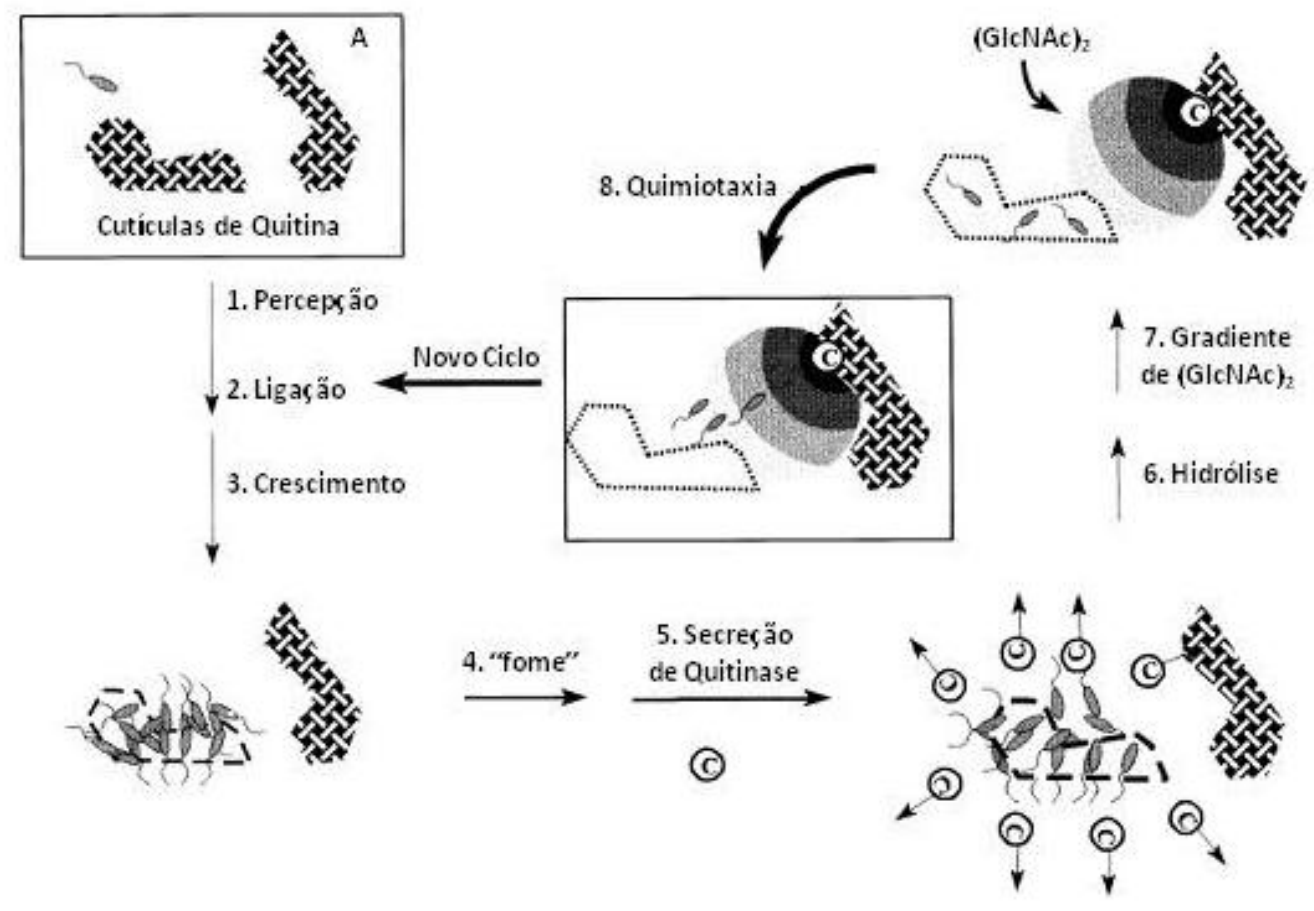

Figura 6 - Visão geral da degradação de quitina realizada por bactéria marinha (Vide texto acima) - (c: quitinase extracelular solúvel.

FONTE: Adaptado de KEYHANI e ROSEMAN, 1999.

O último passo do processo de hidrólise de quitina é o momento da captação e utilização dos compostos resultantes da degradação extracelular do polissacarídeo. Nesse estágio, os oligossacarídeos são transportados para o espaço periplasmático através de porinas localizadas na membrana externa (KEYHANI e ROSEMAN, 1999). Segundo Keyhani et al. (2000) existe uma porina específica denominada quitoporina que realiza o transporte de oligossacarídeos maiores (GlcNAc),$n=2-6$, e o transporte de GlcNAc e outros açúcares é feito por porinas comuns. Em seguida, pelo menos duas hidrolases específicas para oligossacarídeos de quitina presentes no espaço periplasmático degradam os oligossacarídeos em monossacarídeos (GlcNAc) e dissacarídeos $\left[(\mathrm{GlcNAc})_{2}\right]$ os quais atravessam a membrana interna da bactéria através de sistemas de transportes distintos e finalmente chegam ao citoplasma (BASSLER et al., 1991; BOUMA e ROSEMAN, 1996; KEYHANI et al., 1996; KEYHANI e ROSEMAN, 1996a,b; KEYHANI e ROSEMAN, 1997; LI e ROSEMAN, 2004). No citoplasma, os dissacarídeos $\left[(\mathrm{GlcNAc})_{2}\right]$ são primeiramente hidrolisados a 
monossacarídeos (GlcNAc) e em seguida as moléculas de GlcNAc são convertidos a acetato, amônia e frutose 6-fosfato (COMB e ROSEMAN, 1958).

\subsection{DIVERSIDADE DE BACTÉRIAS QUITINOLÍTICAS NO AMBIENTE MARINHO}

Os microrganismos estão presentes em todos os tipos de ambientes. Representam as formas de vida mais abundantes e diversificadas do planeta (AMANN et al., 1995; COLWELL, 1997) e ainda desempenham funções únicas e cruciais na manutenção dos ecossistemas (MYERS, 1996). Mesmo sabendo que existe uma enorme diversidade microbiana, apenas uma pequena porção dessa diversidade é conhecida atualmente, a qual corresponde a menos de $10 \%$ dos microrganismos existentes (AMANN et al., 1995; PROSSER et al., 2007).

Dentre os microrganismos, as bactérias representam a maior biomassa viva existente no planeta e apresentam uma longa história evolutiva, o que permitiu a elas ocupar os mais diferentes ecossistemas e desempenharem as mais variadas funções biológicas. Porém, assim como ocorre com outros microrganismos, o número de bactérias descritas é muito pequeno, correspondendo a 0,1 e 1,0\% do total de espécies bacterianas existentes (ROSELLÓ-MORA e AMANN, 2001).

O ecossistema marinho é um dos ambientes mais ricos em diversidade procariótica, cujo número de bactérias, somente na sub-superfície oceânica, é de aproximadamente $355 \mathrm{x}$ $10^{28}$ (WHITMAN et al., 1998). Os oceanos representam também um ambiente extremamente promissor e pouco explorado, tanto em diversidade genética como em diversidade metabólica, constituindo assim uma inestimável fonte para o descobrimento de novos microrganismos e compostos bioativos importantes para o avanço biotecnológico e para o desenvolvimento auto-sustentável (COLWELL, 1997; ROSSELLÓ-MORA e AMANN, 2001).

Os microrganismos presentes nos oceanos desempenham funções essenciais para a sobrevivência de todos os organismos vivos existentes no nosso planeta. Dentre esses microrganismos, as bactérias quitinolíticas são de fundamental importância nos processos de ciclagem de nutrientes, liberando carbono e nitrogênio para toda a cadeia trófica a partir da degradação da quitina (GOODAY, 1990).

A diversidade de bactérias quitinolíticas começou a ser conhecida em 1935, quando Benton (1935), isolou cepas quitinolíticas de várias fontes, incluindo solo, água, peixes, intestino de sapo e morcego, plâncton, lagosta, insetos, e sedimento de lago. Após essa data, 
inúmeros trabalhos mostraram o isolamento de bactérias quitinolíticas nos mais diversos ambientes, como por exemplo, o trabalho de Campbell e Williams (1951) que identificaram oito novas espécies de bactérias de origem marinha pertencentes aos gêneros Achromobacter, Flavobacterium, Micrococcus e Pseudomonas.

Outros estudos descreveram ainda, a presença de bactérias quitinolíticas em peixes marinhos (FUKASAWA et al., 1992; ITOI et al., 2007; LINDSAY e GOODAY, 1990), baleias (HERWIG e STALEY, 1986), em associação com esponjas marinhas (HAN et al., 2009), em carapaças de camarão (BRZEZINSKA et al., 2008) e caranguejo (JUAREZJIMENEZ et al., 2008) e livres na coluna d'água de ambiente marinho e de água doce (AUMEN, 1981; DONDERSKI, 1984; HERWIG et al., 1988; RAMAIAH et al., 2000; CHANG et al., 2007; FENICE et al., 2007).

A capacidade de degradar quitina tem sido verificada por inúmeras bactérias presentes no ecossistema marinho, dentre as quais podemos citar: Vibrio furnissi (BASSLER et al., 1991; KEYANI e ROSEMAN, 1999), Alteromonas sp. (TSUJIBO et al., 1993; ORIKOSHI et al., 2005), Vibrio harveyi (SVITIL et al., 1997), Vibrio anguillarum e Vibrio parahaemolyticus (HIRONO et al., 1998), Salinivibrio costicola (AUNPAD e PANBANGRED, 2003), Microbulbifer degradans (HOWARD et al., 2003b), Vibrio cholerae (LI e ROSEMAN, 2004; MEIBOM et al., 2004), Vibrio proteolyticus (ITOI et al., 2007), Vibrio alginolyticus (SUGINTA, 2007), Streptomyces sp. (HAN et al., 2009) e Moritella marina (STEFANIDI e VORGIAS, 2008).

Buscando conhecer a diversidade total de bactérias quitinolíticas, muitos trabalhos têm mostrado o isolamento de genes de quitinase de bactérias não cultiváveis, obtidos de ambientes como: solos arenosos (WILLIAMSON et al., 2000), campos de pastagem (KRSEK e WELLINGTON, 2001; METCALFE et al., 2002), lagos de água doce e salina, sedimentos e água estuarinas, Oceano Ártico (LeCLEIR et al., 2004; LeCLEIR et al., 2007), sedimentos da Antártica (XIAO et al., 2005) e fontes termais (HOBEL et al., 2005). Cottrell et al. (2000) sugerem que a exploração de proteobactérias não-cultiváveis degradadoras de quitina possibilitará um melhor entendimento do processo de degradação de quitina nos oceanos, visto que trabalhos de clonagem de genes de quitinases de microrganismos marinhos não cultiváveis mostram a presença de uma grande quantidade de bactérias com capacidade de degradar quitina em ecossistemas aquáticos. 


\subsection{ASSOCIAÇÃO ENTRE BACTÉRIAS QUITINOLÍTICAS E ORGANISMOS MARINHOS}

Em ambientes aquáticos, as bactérias apresentam uma forte afinidade por inúmeros tipos de substratos, podendo ser encontradas associadas com zooplâncton e fitoplâncton e em simbiose com corais, esponjas, lulas e matéria orgânica em suspensão, o que possibilita a sobrevivência dessas bactérias por mais tempo em condições ambientais adversas em comparação com bactérias que vivem livres na coluna d'água (CARMAN e DOBBS, 1997; DeLONG, 2001; PRUZZO et al., 2008; ROSZACK e COLWELL, 1987; RUBIN, 2000; SHERR e SHERR, 2000).

$\mathrm{O}$ exoesqueleto quitinoso e o trato digestivo de zooplâncton carregam uma microbiota comensal natural que é composta principalmente por Vibrios sp. A capacidade do V. cholerae de se ligar à quitina vem sendo estudada por inúmeros pesquisadores, visto que para a ecologia microbiana, é um dos melhores exemplos de interação bem sucedida entre bactéria e substrato (HUQ et al., 1983; TAMPLIN et al., 1990; COLWELL, 2002).

A associação entre $V$. cholerae e zooplâncton fornece à bactéria um ambiente rico em nutrientes (HEIDELBERG et al., 2002), porém tem significantes implicações no início e dispersão de epidemias de cólera (COLWELL, 1996; HUQ e COLWELL, 1996). Até o ano de 2005, acreditava-se que o genoma de $V$. cholerae teria evoluído somente através do mecanismo de transdução e conjugação. Porém, Meibom et al. (2005) demonstraram que $V$. cholerae pode adquirir novos genes por transferência horizontal de genes durante o crescimento sobre quitina. Vale ressaltar, que a quitina ainda é responsável pela regulação de proteínas envolvidas na patogenicidade do $V$. cholerae (REGUERA e KOLTER, 2005) e aumenta a sobrevivência dessa bactéria durante situações de stress ambiental, como variações bruscas de temperatura e pH (AMAKO et al., 1987; HUQ e COLWELL, 1996). Shukla et al. (1995) demonstraram que certas cepas não cultiváveis pertencentes aos gêneros Vibrios e Aeromonas podem ser recuperadas do exoesqueleto de artrópodes aquáticos, sugerindo assim que várias espécies de zooplâncton podem atuar como reservatórios de espécies bacterianas toxigênicas, como por exemplo o $V$. cholerae $\mathrm{O} 1$.

Sob condições normais e mesmo tendo uma população microbiana epibiótica, a carapaça dos crustáceos não é significativamente degradada até que ela seja liberada através do processo de muda ou morte do animal. Mas em alguns casos, a degradação do exoesqueleto ocorre com o crustáceo vivo, resultando assim em uma condição conhecida 
como síndrome da doença da carapaça (Shell Disease Syndrome) (VOGAN et al., 2008). Os agentes etiológicos causadores das lesões podem variar de acordo com a localização geográfica da população do crustáceo. Porém, vários casos da doença foram evidenciados em animais de ambientes poluídos (GOPALAN e YOUNG, 1975; WEINSTEIN et al., 1992) sugerindo que situações de deterioração ambiental podem desencadear o início da doença (VOGAN et al., 2008).

\subsection{ATIVIDADE QUITINOLÍTICA BACTERIANA}

Bactérias quitinolíticas são tipicamente detectadas pela formação de zonas claras (halos) ao redor das colônias que crescem em meio de cultura sólido contendo quitina como única fonte de carbono. Nesse caso, o diâmetro desse halo indica o potencial de produção de quitinases pelas bactérias quitinolíticas (AKUTSU et al., 1993; AVELIZAPA et al., 1999; CODY et al., 1990; HOWARD et al., 2003a). Keyhani e Roseman (1999) mostraram que a degradação da quitina por Vibrio furnisii pôde ser visualizada em placas através da formação de halo ao redor das colônias, em meio de cultura contendo quitina como única fonte de carbono. Porém, quando essa bactéria foi cultivada em meios de cultura contendo outras fontes de carbono e quitina, esse halo não foi visualizado, visto que a quitinase microbiana é uma enzima que se expressa quando a quitina é a única fonte de carbono presente no meio de cultura.

Devido à característica insolúvel da quitina em água (HACKMAN e GOLDBERG, 1965), na maioria dos experimentos envolvendo bactérias quitinolíticas é utilizada a quitina coloidal como única fonte de carbono. Esse tipo de quitina é produzido através do tratamento da carapaça de crustáceos com ácido clorídrico ou sulfúrico seguido por precipitação com etanol, tornando-a mais solúvel em meio de cultura (RAMÍREZ et al., 2004; ROBERTS e SELITRENNIKOFF, 1988; RODRIGUEZ-KABANA et al., 1983; SHIMAHARA e TAKIGUCHI, 1988; SKUJINS et al., 1965; WEN et al., 2002;).

O uso de substratos cromogênicos como, por exemplo, o nitrofenol ( $p$-nitrofenol ou $o$ nitrofenol) ligados à GlcNAc ou a oligossacarídeos de quitina, tem sido empregados para detecção de enzimas quitinolíticas específicas, como quitobiosidase, $\beta$ - $N$-acetilglicosaminidase e endoquitinase. Nesse tipo de ensaio, quando o p-nitrofenol (PNP) é liberado do oligossacarídeo de quitina ou da GlcNAc por enzimas quitinolíticas, ele pode ser detectado por espectrofotômetro a uma absorbância de 410 ou $405 \mathrm{~nm}$ e a quantidade de PNP 
pode ser quantificada usando uma curva padrão preparada com $p$-nitrofenol (BASSLER et al., 1991; FRÄNDBERG e SCHNÜRER, 1994a; SVITIL et al., 1997; KEYHANI e ROSEMAN, 1999; MATSUO et al., 1999; HOWARD et al. 2003a; ORIKOSHI et al., 2005; SUGINTA, 2007). Entretanto, um dos métodos mais utilizados para detecção de atividade quitinolítica é baseado na dosagem dos açúcares redutores formados a partir da degradação da quitina coloidal. Porém, esse tipo de método colorimétrico não especifica quais as enzimas quitinolíticas atuaram no processo de hidrólise da quitina coloidal (FRÄNDBERG e SCHNÜRER, 1994a; GARCIA, 1993; HOWARD et al., 2003a).

Os trabalhos enfocando a detecção de enzimas quitinolíticas produzidas por microrganismos têm mostrado que as bactérias produzem diferentes quitinases, provavelmente para hidrolisar diferentes formas de quitina, pois uma única quitinase não hidrolisa igualmente e com a mesma eficiência as formas $\alpha$ e $\beta$-quitina (SVITIL et al., 1997). Quitinase isolada de Bacillus sp. degrada $\beta$-quitina mais eficientemente do que $\alpha$-quitina, talvez por ser mais difícil para as quitinases terem acesso e hidrolisarem cadeias antiparalelas de $\alpha$-quitina. Isso pode explicar por que muitos organismos têm $\alpha$ ao invés de $\beta$-quitina no exoesqueleto ou parede celular (SHIGEMASA et al., 1994).

Watanabe e colaboradores (1990a) encontraram seis diferentes quitinases (A1, A2, B1, B2, C e D) produzidas por Bacillus circulans WL-12 em meio base nitrogênio-levedura ("yeast-nitrogen base" - YNB) contendo 0,2\% de quitina e 0,5\% de extrato de levedura. Eles afirmam que não é provável que a bactéria contenha seis genes diferentes para codificar essas quitinases, visto que algumas delas parecem ter sido derivadas das outras. A semelhança entre a sequência de aminoácidos da porção N-terminal da quitinase A1 e A2 e o tamanho das quitinases indicam que a quitinase A2 foi derivada da quitinase A1 provavelmente pela remoção proteolítica da porção C-terminal da quitinase A1. A quitinase A1 foi detectada no sobrenadante somente no $1^{\circ}$ e $2^{\circ}$ dia de cultivo, onde a diminuição e o desaparecimento da quitinase A1 foi acompanhada pelo aparecimento e aumento da quitinase A2. Então, a conversão de quitinase A1 para quitinase A2 parece ter ocorrido após a secreção da quitinase A1 no meio de cultura. Foi observada nas quitinases B1 e B2, produzidas no mesmo experimento, um processo similar ao ocorrido com as quitinases A1 e A2.

Entre as cinco quitinases (A1, A2, B1, B2 e C) detectadas no segundo dia, no sobrenadante da cultura de B. circulans WL-12, somente a quitinase A1 mostrou forte afinidade por quitina insolúvel. As quitinases A1 e A2 mostraram maiores atividades na degradação de quitina coloidal e somente a quitinase A1 degradou quitina coloidal 
diretamente à (GlcNAc) 2. Com isso, pôde-se concluir que a quitinase A1 é a quitinase mais importante para o processo de degradação de quitina realizado por B. circulans WL-12. Quanto às outras quitinases, não foi possível afirmar qual a função delas dentro desse processo de degradação de quitina, mas acredita-se que algumas delas estejam envolvidas na indução da quitinase A1 (WATANABE et al., 1990a,b).

Sabe-se que a degradação da quitina é realizada por um caminho complexo que incluem múltiplas enzimas (SVITIL et al., 1997). Porém, na maioria dos estudos de diversidade de quitinases em ambientes aquáticos, a quitinase $\mathrm{A}$ (ChiA), que é uma endoquitinase extracelular é o alvo das pesquisas, visto que o gene chiA é aparentemente conservado em membros dos filos Proteobacteria e Firmicutes (COTTRELL et al., 1999; COTTRELL et al., 2000; LECLEIR et al., 2004; RAMAIAH et al., 2000). Adicionalmente, em microrganismos que apresentam múltiplas quitinases, a ChiA é a enzima que apresenta maior expressão e atividade na presença de quitina de carapaça de caranguejo, sugerindo que essa enzima possa ser a mais ativa no ambiente (SVITIL et al., 1997; ORIKOSHI et al., 2005).

No entanto, a utilização do gene chiA para identificar degradadores de quitina é problemática, pois esse gene apresenta diferenças mesmo entre membros de uma mesma família bacteriana, o que dificulta o emprego de primers para amplificação dessa região (HUNT et al., 2008). Cottrell et al. (2000) sugerem que as diferenças existentes na sequência do gene chiA são resultantes da transferência lateral de genes entre grupos de bactérias e ainda afirmam que outros mecanismos como a duplicação do gene podem estar envolvidos nesse processo. Mas, mesmo que o gene chiA possa estar sujeito a transferência lateral e/ou duplicação, não existe outro gene que sirva como um bom indicador da atividade quitinolítica, visto que outros genes de quitinases não estão presentes no genoma de muitas bactérias quitinolíticas já estudadas (HUNT et al., 2008).

\subsection{CARACTERIZAÇÃO MOLECULAR DE BACTÉRIAS QUITINOLÍTICAS}

A identificação de microrganismos tem sido realizada, tradicionalmente, por metodologias baseadas em características fenotípicas. Porém, o emprego de métodos genotípicos, como AFLP (Amplified Fragment Lenght Polymorphism), MLEE (Multilocus Enzyme Electrophoresis), MLST (Multilocus Sequence Typing), MLSA (Multilocus Sequence Analysis), RAPD (Randomly amplified polymorphic DNA), rep-PCR (Repetitive Element 
Sequence-based Polymerase Chain Reaction), DGGE (Denaturing-gradient gel Electrophoresis), hibridação DNA-DNA e análises de seqüências do gene 16S rDNA, utilizados para caracterização e identificação microbiana aumentou consideravelmente nos últimos (GÜRTLER e MAYALL, 2001; RADEMAKER et al., 2004; RADEMAKER e SAVELKOUL, 2004; van BELKUM et al., 2001). Cada um desses métodos tem suas vantagens e desvantagens em termos de facilidade de aplicação, reprodutibilidade, necessidade de equipamentos sofisticados e nível de resolução filogenética e taxonômica (RADEMAKER e de BRUIJN, 1997; RADEMAKER e SAVELKOUL, 2004; VANDAMME et al., 1996).

Entretanto, as técnicas de rep-PCR e sequenciamento da região 16S rRNA têm sido empregadas com bastante frequência na caracterização e identificação molecular dos microrganismos, devido à eficiência, à confiabilidade, alto poder discriminatório e baixo custo (CHIMETTO et al., 2009; LUPSKI e WEINSTOCK, 1992; MUYZER et al., 1993; MUYZER e SMALLA, 1998; RADEMAKER et al., 2004; VANEECHOUTTE et al.,1993; VERSALOVIC et al., 1998; WILLIAMS et al., 1990).

As técnicas de rep-PCR possibilitam o conhecimento da diversidade genética existente entre cepas bacterianas através da análise de várias sequências repetitivas localizadas em posições intergênicas distintas distribuídas no genoma de procariotos, as quais ocupam mais de 5\% do genoma microbiano (LUPSKI e WEINSTOCK, 1992; USSERY et al., 2004). Dentre as sequências repetitivas conhecidas atualmente, três têm sido utilizadas com maior frequência para caracterização genotípica de isolados de origem clínica e ambiental: REP (Repetitive Extragenic Palindromic Sequence), ERIC (Enterobacterial Repetitive Intergenic Consensus) e BOX (Invertedly Repeated Elements) (BINDE et al., 2009; deBRUIJN, 1992; DOMBEK et al., 2000; ISHII e SADOWSKY, 2009; LUPSKI e WEINSTOCK, 1992; MENNA et al., 2009; RIVERA et al., 1995; SOUZA, 2007; ZO et al., 2002).

As seqüências REP, ERIC e BOX possuem respectivamente, 35-40 pares de bases (pb), 124-127 pb e 154 pb e, ainda permanece desconhecida a função desses elementos dentro do genoma dos microrganismos (de BRUIJN, 1992; KOEUTH et al., 1995; LUPSKI e WEINSTOCK, 1992). Para cada sequência são utilizados iniciadores específicos (primers) que, após o processo de amplificação pela técnica de PCR, resulta em produtos de amplificação de DNA de diferentes tamanhos. Esses produtos de PCR são visualizados em gel de agarose e mostram o perfil genômico (fingerprints) da cepa de interesse. O perfil obtido por essa técnica pode ser específico para cada cepa, podendo assim diferenciar um 
microrganismo de outro (LOUWS et al., 1996; KOEUTH et al., 1995; RADEMAKER e deBRUIJN, 1997; RADEMAKER et al., 2008; VERSALOVIC et al., 1998).

Uma das grandes vantagens da técnica de rep-PCR é a caracterização molecular de uma ampla variedade de microrganismos devido ao seu alto poder discriminatório e baixo custo, além de poder gerar perfis genômicos a partir de DNA purificado e também de células lisadas em meio líquido (LOUWS et al., 1996; OLIVE e BEAN, 1999; RADEMAKER e deBRUIJN, 1997; VERSALOVIC et al., 1994; VERSALOVIC et al., 1998; WOODS et al., 1993).

Em 1990, Carl Woese revolucionou o campo da microbiologia com as suas comparações filogenéticas baseadas nos genes que codificam para o rRNA, dando início assim à teoria dos três domínios da vida (WOESE et al., 1990). Hoje, as análises baseadas no 16S rRNA é uma das metodologias mais usadas no dia-a-dia para identificação bacteriana e também para explorar a diversidade microbiana em amostras ambientais (AMANN e LUDWIG, 2000; KONSTANTINIDIS e TIEDJE, 2007; ROSELLÓ-MORA e AMANN, 2001).

$\mathrm{O}$ gene $16 \mathrm{~S}$ rDNA possui características fundamentais que possibilitam a sua utilização na identificação de bactérias e em estudos de ecologia microbiana, como por exemplo, a presença de regiões com sequências de nucleotídeos hiper-variáveis entre regiões conservadas, a aparente ausência de transferência lateral de genes, ele está presente em todos os procariotos e possui aproximadamente 1500 nucleotídeos que é um tamanho satisfatório para estudos filogenéticos (AMANN e LUDWIG, 2000; AMANN et al., 1995; WOESE, 1987).

A disponibilidade de enormes bancos de dados tais como o GenBank (National Center for Biotechnology Information - httt://www.ncbi.nlm.nig.gov) e o Ribosomal Database Project (RDP - rdp.cme.msu.edu), no qual novas sequências de 16S rRNA obtidas podem ser comparadas com sequências existentes, também é uma das grandes vantagens da utilização do 16S rRNA em comparações filogenéticas (BENSON et al., 2004; MAIDACK et al., 1996; WHEELER et al., 2005). Todavia, o 16S rRNA tem a desvantagem de apresentar uma limitada resolução em nível de espécie, sendo necessário a utilização de outras metodologias como a hibridação DNA-DNA para confirmar a espécie de uma determinada bactéria (FOX et al., 1992; KONSTANTINIDIS e TIEDJE, 2005a,b; KONSTANTINIDIS et al., 2006; ROSELLÓ-MORA e AMANN, 2001). 


\subsection{APLICAÇÕES BIOTECNOLÓGICAS DAS QUITINASES}

O ambiente marinho é uma rica fonte, tanto em diversidade biológica como de compostos químicos. E essa diversidade possibilita a descoberta de importantes produtos que são usados, como por exemplo, na indústria farmacêutica e de cosméticos, na agricultura e na produção de suplementos nutricionais (COLWELL, 1997).

Nas últimas décadas, com o aparecimento de novas doenças e de microrganismos resistentes aos medicamentos já existentes, houve um grande interesse pela busca de novos produtos bioativos naturais e, com isso, viu-se no ambiente marinho um campo bastante atrativo e pouco explorado do ponto de vista biotecnológico e microbiológico (KELECOM, 1999).

As aplicações biotecnológicas de enzimas constituem um vasto campo de possibilidades em áreas como agricultura, medicina e setor industrial, pois elas permitem às indústrias usarem processos mais econômicos, diminuindo o consumo de energia e possibilitando o uso de recursos mais confiáveis e que poluem menos. É interessante ressaltar que as altas temperaturas, fortes ácidos ou álcalis e perigosos produtos químicos utilizados em muitos processos industriais significam perigo potencial ao local de trabalho e ao meio ambiente (OUTTRUP e JORGENSEN, 2002). Diante disso, as enzimas podem substituir muitos desses produtos químicos e permitir uma produção segura, contribuindo assim para a preservação do meio ambiente e do desenvolvimento sustentável.

As quitinases podem ser usadas na agricultura para controle de insetos e fungos ou para o desenvolvimento de plantas transgênicas resistentes ao ataque de microrganismos (AJIT et al., 2006; TANAKA et al., 1970; ZHANG et al., 2001). Quitinases produzidas por Enterobacter sp. NRG4 mostraram-se altamente ativas contra Fusarium moniliforme, Aspergillus niger, Mucor rouxi e Rhizopus nigricans (DAHIYA et al., 2005). Em outro experimento, a quitinase de Alcaligenes xylosoxydans inibiu o crescimento de Fusarium udum e Rhizoctonia bataticola (VAIDYA et al., 2001). Quitinase purificada de Trichoderma harzianum destruiu a parede celular de Crinipellis perniciosa, o agente causador da "vassoura de bruxa" em plantações de cacau (DeMARCO et al., 2000).

Outra aplicação das quitinases é a produção de quitosana a partir de quitina de crustáceos e ostras. A quitosana é uma forma desacetilada da quitina e apresenta propriedades biológicas tais como: baixa toxicidade, é biodegradável, anticoagulante, antifúngica, 
antimicrobiana e não alérgica (ILLUM, 1998). A quitosana pode ser utilizada em sistemas de tratamento de efluentes de indústrias alimentícias, na remoção de metais pesados, ácidos e corantes em sistemas de tratamento de efluentes de indústrias têxteis, na indústria alimentícia, na indústria de cosméticos, na agricultura, na indústria farmacêutica e na área biomédica (KUMAR, 2000; NO e MEYERS, 2000; PRABAHARAN, 2008).

O consumo de crustáceos, principalmente em países costeiros, é bastante elevado, mas somente a carne é consumida e o exoesqueleto é jogado fora, ocorrendo um grande acúmulo de produtos de quitina provenientes do processamento desses crustáceos. Há dados que em alguns países desenvolvidos são produzidos mais de 2,5 toneladas de carapaças de camarão por ano. A bioconversão de quitina, utilizando quitinases, em produtos de alto valor agregado como a quitosana, seria uma alternativa para diminuir os resíduos provenientes do processamento de produtos marinhos (HAKI e RAKSHIT, 2003; VYAS e DESHPANDE, 1991).

Há um crescente interesse no potencial de oligossacarídeos biologicamente ativos como o $N$-acetil-quitoheptaose (GlcNAc) 7 e o $N$-acetil-quitohexaose (GlcNAc) 6 , os quais apresentam atividade antitumoral. Esses quito - oligômeros são obtidos através da hidrólise ácida da quitina e quitosana. No entanto, essa metodologia resulta em baixo rendimento e produção de resíduos químicos. Com isso, a via enzimática parece ser um método rápido e simples para obtenção desses compostos (ALOISE et al., 1996; YAMANOI et al., 2004).

Zhu e colaboradores (2004) afirmam que a quitinase AMCase (acidic mammalian chitinase) apresenta potencial terapêutico e sugerem a sua utilização no tratamento da asma humana. Trabalhos mais antigos sugeriram o emprego de quitinases no tratamento de doenças causadas por fungos, utilizando essa enzima para potencializar a atividade de drogas antifúngicas (ORUNSI e TRINCI, 1985; POPE e DAVIS 1979).

\subsection{O AMBIENTE MARINHO BRASILEIRO}

Os oceanos cobrem aproximadamente $71 \%$ da superfície terrestre e desempenham um papel crucial na sustentabilidade da vida na Terra, além de serem importantes reguladores do clima terrestre. A média de profundidade dos oceanos é de 4.000 metros. Porém, próximo aos limites continentais, os habitats marinhos são geralmente menores, devido à presença expansiva da plataforma continental, onde apresentam no máximo uma profundidade de 200 metros. Os ambientes marinhos costeiros são influenciados pela entrada de materiais 
provenientes do continente, tais como sedimentos, água doce, carbono orgânico e nutrientes, os quais influenciam na variabilidade desse habitat e afetam a produtividade microbiana (ANGEL, 1993; KARL, 2007; UNITED NATIONS, 2008).

As águas costeiras constituem a interface entre os ambientes marinhos e de água doce e entre o continente e os oceanos (UNITED NATIONS, 2008). As zonas costeiras incluem a plataforma continental, os estuários, as lagoas, os deltas e as planícies e barreiras costeiras (RAY, 1991). A região costeira brasileira se estende desde o Cabo Orange $\left(4^{\circ} \mathrm{N}\right)$ até o Chuí $\left(34^{\circ} \mathrm{S}\right)$, correspondendo a aproximadamente $8.500 \mathrm{~km}$ de extensão. Essa região é composta por importantes ecossistemas, dentre os quais podemos citar: os recifes e corais, as praias, os manguezais, as dunas e falésias, baías, estuários, etc. Muitos desses ecossistemas são extremamente frágeis e estão em acentuado processo de degradação gerado pela crescente ocupação populacional (FERREIRA, 2001; STRAMMA e ENGLAND, 1999).

O litoral do estado de São Paulo tem uma extensão de aproximadamente $860 \mathrm{~km}$, considerando os costões e as praias continentais. As principais atividades econômicas do litoral paulista são: o turismo, as atividades industriais e portuárias, a maricultura e a pesca. Essas atividades concentram-se em diferentes municípios e são também potenciais fontes de poluição que podem interferir na qualidade dos recursos hídricos locais (COMPANHIA DE TECNOLOGIA DE SANEAMENTO AMBIENTAL - CETESB, 2008) e na biodiversidade do ambiente marinho.

O Canal de São Sebastião, o município de Ubatuba e a Baixada Santista localizados no litoral do estado de São Paulo, são importantes regiões, tanto do ponto de vista econômico quanto de diversidade biológica e apresentam características físicas, químicas e biológicas distintas entre si.

\subsubsection{Canal de São Sebastião}

O Canal de São Sebastião fica localizado no litoral norte do estado de São Paulo entre o município de São Sebastião e a Ilha de São Sebastião. Esse canal tem $25 \mathrm{~km}$ de extensão e as entradas possuem configuração afunilada com larguras aproximadas de 7,2 e 5,6 km, com uma parte mais estreita de aproximadamente $1,9 \mathrm{~km}$, localizada na Ponta do Araçá. A profundidade varia entre $20 \mathrm{~m}$ nas entradas norte e sul, até uma profundidade máxima de aproximadamente $50 \mathrm{~m}$ na parte central do canal, próximo ao Porto de São Sebastião (FURTADO, 1995; SILVA, 2001). 
As características termohalinas da água do mar na região do Canal de São Sebastião são determinadas pela mistura em proporções variáveis da Água Costeira (AC), que apresenta alta temperatura e baixa salinidade $\left(>20^{\circ} \mathrm{C}\right.$ e $32,2-35,4 \%$ ), Água Tropical (AT) com altos valores de temperatura e salinidade $\left(>20^{\circ} \mathrm{C}\right.$ e $>36,4 \%$ ), Água Central do Atlântico Sul (ACAS) que contém temperatura e salinidade relativamente baixas $\left(<20^{\circ} \mathrm{C}\right.$ e $<36,4 \%$ ), pelo padrão de correntes geradas principalmente pelo vento e pelas condições climatológicas prevalecentes na região (CASTRO FILHO et al., 1987; CASTRO FILHO, 1990).

As ondas de marés chegam à costa por leste e sudeste e alcançam as duas entradas do Canal simultaneamente, o que possibilita observar baixas amplitudes de marés no interior do Canal. As correntes não são fortemente afetadas pelas marés, mas são influenciadas pelas condições meteorológicas, pela topografia, e, principalmente, pelos ventos. Os ventos vindos do sul direcionam as correntes para o norte, enquanto que ventos do norte direcionam as correntes para sudoeste (CASTRO FILHO, 1990; KVINGE, 1967).

A região do Canal de São Sebastião é de grande importância econômica e social, não somente por seus recursos naturais, mas também pela localização de centros urbanos, área de lazer, atividades pesqueiras e por conter um dos mais importantes terminais petrolíferos do país, o Terminal Almirante Barroso (TEBAR). Além do terminal, o Canal de São Sebastião abriga o Porto de São Sebastião, o Centro de Biologia Marinha-CEBIMAR/USP e nele ainda desembocam três emissários submarinos que lançam esgotos municipais (MENDES, 2007).

\subsubsection{Ubatuba - Saco da Ribeira}

É uma pequena enseada localizada no trecho sul do município de Ubatuba, litoral norte do estado de São Paulo, onde apresenta grande concentração de estabelecimentos voltados para o turismo e atividade náutica. Graças à sua privilegiada posição geográfica de proteção do embate direto das ondas, é utilizada como marina estadual, concentrando veleiros de várias partes do mundo, além de embarcações pesqueiras. Nessa região encontra-se o único posto de abastecimento de combustíveis flutuante do Litoral Norte e uma base do Instituto Oceanográfico da Universidade de São Paulo (COMPANHIA DE TECNOLOGIA DE SANEAMENTO AMBIENTAL - CETESB, 2008).

A região é caracterizada por um regime oligo- a mesotrófico, sendo a produtividade primária marinha limitada pela escassez de nutrientes inorgânicos, devido à baixa contribuição terrestre (BRAGA e MULLER, 1998). A produtividade primária da região é 
dominada por espécies de nanoplâncton, mesmo nas épocas de maiores produtividades, quando blooms esporádicos de diatomáceas podem ocorrer (SASSI e KUTNER, 1982).

No verão, a influência dominante na produtividade primária é associada à predominância de ventos paralelos à costa e ao aumento no regime de chuvas e tempestades. A presença da Água Central do Atlântico Sul, uma massa d'água fria e rica em nutrientes sobre o domínio interno da plataforma continental (10 a $50 \mathrm{~m}$ de profundidade), promove incremento de nutrientes na zona eufótica, ocorrendo blooms esporádicos de organismos planctônicos. O aumento da ocorrência de chuvas e tempestades promove maior entrada de matéria suspensa, sedimento e matéria orgânica de origem continental que também contribuem para o aumento da produtividade da região durante os meses de primavera-verão (GAETA et al., 1999; MAHIQUES, 1995; PIRES-VANIN e MATSUURA, 1993).

No outono-inverno, o resfriamento das águas superficiais e uma maior interação da Água Tropical e da Água Costeira tornam as águas próximas à costa quase homogêneas. Nessa época do ano, com o aumento das frentes frias e a homogeneidade da coluna de água, a ressuspensão e regeneração de nutrientes tornam-se os principais fatores responsáveis pela produtividade primária na região (SASSI e KUTNER, 1982).

\subsubsection{Baixada Santista}

O complexo estuarino de Santos está localizado na porção central do litoral paulista e engloba as Baías de Santos e São Vicente, sendo formado por uma área que abrange $40 \mathrm{~km}$ de extensão por $15 \mathrm{~km}$ de largura em sua parte mais ampla (CETESB, 2000). É delimitada nas suas extremidades pela Serra de Mongaguá, ao sul e pela parte rochosa da Ilha de Santo Amaro ao norte. Na área central e nordeste, a planície é drenada por uma rede de lacunas e canais de maré que delimitam as ilhas de São Vicente e Santo Amaro (FUKUMOTO, 2003).

A área apresenta um clima litorâneo quente e úmido (ou super úmido), característico do tipo tropical úmido com altos índices de precipitação pluviométrica, sujeita a uma ampla oscilação térmica devido à ação dinâmica da Frente Polar Atlântica, sofrendo ação direta do sistema de brisas e não possuindo estação seca definida. A temperatura média anual é de $22{ }^{\circ} \mathrm{C}$ e os totais pluviométricos oscilam entre $2000 \mathrm{~mm}$ no litoral e $4500 \mathrm{~mm}$ nas encostas (FUNDAÇÃO DE ESTUDOS E PESQUISAS AQUÁTICAS, 1994). 
A circulação de água na baía de Santos e áreas adjacentes é bastante complexa, com contribuições de marés e ventos. As águas oriundas da plataforma continental entram na baía pela face oeste, enquanto que águas mais salobras, provenientes do estuário de Santos, entram pela face leste. Já a plataforma adjacente, denominada Plataforma Continental Sudeste do Brasil, abriga as massas de Água Costeira, Água Tropical e Água Central do Atlântico Sul (ACAS) (BRAGA e NIENCHESKI, 2006; HARARI et al., 1999).

A Água Costeira ocupa a região mais interna da plataforma e é resultante da mistura da descarga continental de água doce, o que resulta nos menores valores de salinidade da área e altos índices de nutrientes como silicatos, nitrato e fosfato. A Água Tropical, situada externamente à Água Costeira e nas camadas superficiais, apresenta valores altos de temperatura $\left(>20^{\circ} \mathrm{C}\right)$ e salinidade $(>36 \%$ ) e baixas concentrações de nutrientes ao longo do sudeste brasileiro. A Água Central do Atlântico Sul situa-se nas camadas inferiores e é mais expressiva no verão, apresentando baixos índices de temperatura e salinidade e alta concentração de nutrientes, ocasionando assim, aumentos sazonais da produtividade do ecossistema, quando ocorre a ressurgência dessa massa de água (BRAGA e NIENCHESKI, 2006; CASTRO et al., 2006).

A baía de Santos recebe grande aporte de nutrientes através dos canais de São Vicente e de Santos, sendo que o Canal de Santos também é responsável pela dispersão de metais pesados para o sedimento adjacente ao canal até a Ilha da Moela, devido ao transporte executado pelas embarcações que fazem a dragagem do canal (ARGENTINO-SANTOS, 2006).

Atualmente, as principais fontes de contaminação no Estuário de Santos e São Vicente são o Porto de Santos, o Pólo Industrial de Cubatão, os lixões, os despejos de esgoto que ocorrem de forma clandestina (MARTINS, 2005; MEDEIROS, 2000) e o emissário de Santos, que possui apenas 4 quilômetros de extensão e despeja, dentro da baía, o esgoto doméstico proveniente da cidade de Santos, o qual é responsável pela emissão de alta carga de nutrientes, surfactantes e metais pesados (ABESSA et al., 2005; MARTINS, 2005). 


\section{OBJETIVOS}

\subsection{OBJETIVO GERAL}

O presente trabalho visa estudar aspectos ecológicos e biotecnológicos do processo de degradação de quitina no ambiente marinho, procurando conhecer a diversidade de bactérias quitinolíticas em amostras de água do mar e plâncton coletadas em três ambientes marinhos que apresentam diferentes níveis de impactos antropogênicos. E ainda selecionar bactérias quitinolíticas que possam ser empregados em processos biotecnológicos.

\subsection{OBJETIVOS ESPECÍFICOS}

- Selecionar a metodologia de preparação de quitina coloidal.

- Padronizar o meio de cultura para isolamento de bactérias quitinolíticas contendo quitina coloidal como única fonte de carbono.

- Enumerar as bactérias quitinolíticas viáveis em amostras de água do mar e plâncton coletadas no Canal de São Sebastião, Ubatuba e Baixada Santista através da técnica de contagem em placas.

- Verificar o potencial de degradação de quitina das bactérias quitinolíticas obtidos de amostras de água do mar e plâncton, através do diâmetro do halo de hidrólise de quitina produzido em meio mínimo contendo quitina coloidal.

- Quantificar as quitinases, produzidas pelas bactérias quitinolíticas, através da liberação de $N$-acetil-glicosamina (GlcNAc).

- Quantificar as enzimas Quitobiosidase, $\beta$ - $N$-acetil-glicosaminidase e Endoquitinase produzidas pelas bactérias quitinolíticas.

- Caracterizar a diversidade de bactérias quitinolíticas dos três ambientes estudados através das técnicas de rep-PCR e sequenciamento da região 16S rRNA. 


\section{MATERIAL E MÉTODOS}

\subsection{COLETA DE AMOSTRAS}

\subsubsection{Período de amostragem e pontos de coleta}

As coletas de amostras de água do mar e plâncton foram realizadas no Canal de São Sebastião, Ubatuba e na Baixada Santista no litoral do estado de São Paulo. Esses locais foram selecionados após uma análise prévia dos dados de balneabilidade apresentados no relatório anual da Companhia de Tecnologia de Saneamento Ambiental (2004), procurando selecionar os ambientes com características distintas em relação ao nível de impacto antropogênico presente em cada região.

- Canal de São Sebastião: As amostras foram coletadas mensalmente, no período de agosto de 2005 a março de 2007, em dois pontos: (i) Ponto 1 - em frente à Praia do Segredo (Latitude $23^{\circ} 49^{\prime} 50^{\prime}$ ' S, Longitude $45^{\circ} 25^{\prime} 20^{\prime}$ ' W), (ii) Ponto 2 - na região norte da Praia de Baraqueçaba (Latitude 23 49' 56' S, Longitude $45^{\circ} 25^{\prime}$ 51', W) (Figura 7).

- Ubatuba: Foram selecionados dois pontos de coleta: (i) Ponto 1 -

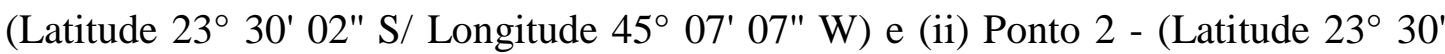
$41^{\prime \prime}$ S/ Longitude $45^{\circ} 06^{\prime} 04^{\prime \prime} \mathrm{W}$ ) e as amostras foram coletadas nos meses de fevereiro a maio de 2006 e janeiro a março de 2007 (Figura 7).

- Baixada Santista: As coletas de amostras foram realizadas nos meses de fevereiro a maio de 2006 e janeiro a março de 2007 em três pontos de coleta: (i) Ponto 1 - entrada da cidade de São Vicente (Latitude $23^{\circ} 59^{\prime} 56^{\prime}$ 'S/ Longitude $46^{\circ} 22^{\prime} 26^{\prime}$ ' W), (ii) Ponto 2 - Boca da Barra, depois da Ilha das Palmas (Latitude 2402' 25', S/Longitude $46^{\circ} 19^{\prime} 20^{\prime}$ 'W) e (iii) Ponto 3 - próximo à Marina Astúrias (Latitude 235' 50’' S/ Longitude $46^{\circ} 17^{\prime} 99^{\prime}$ ' W) (Figura 7). 

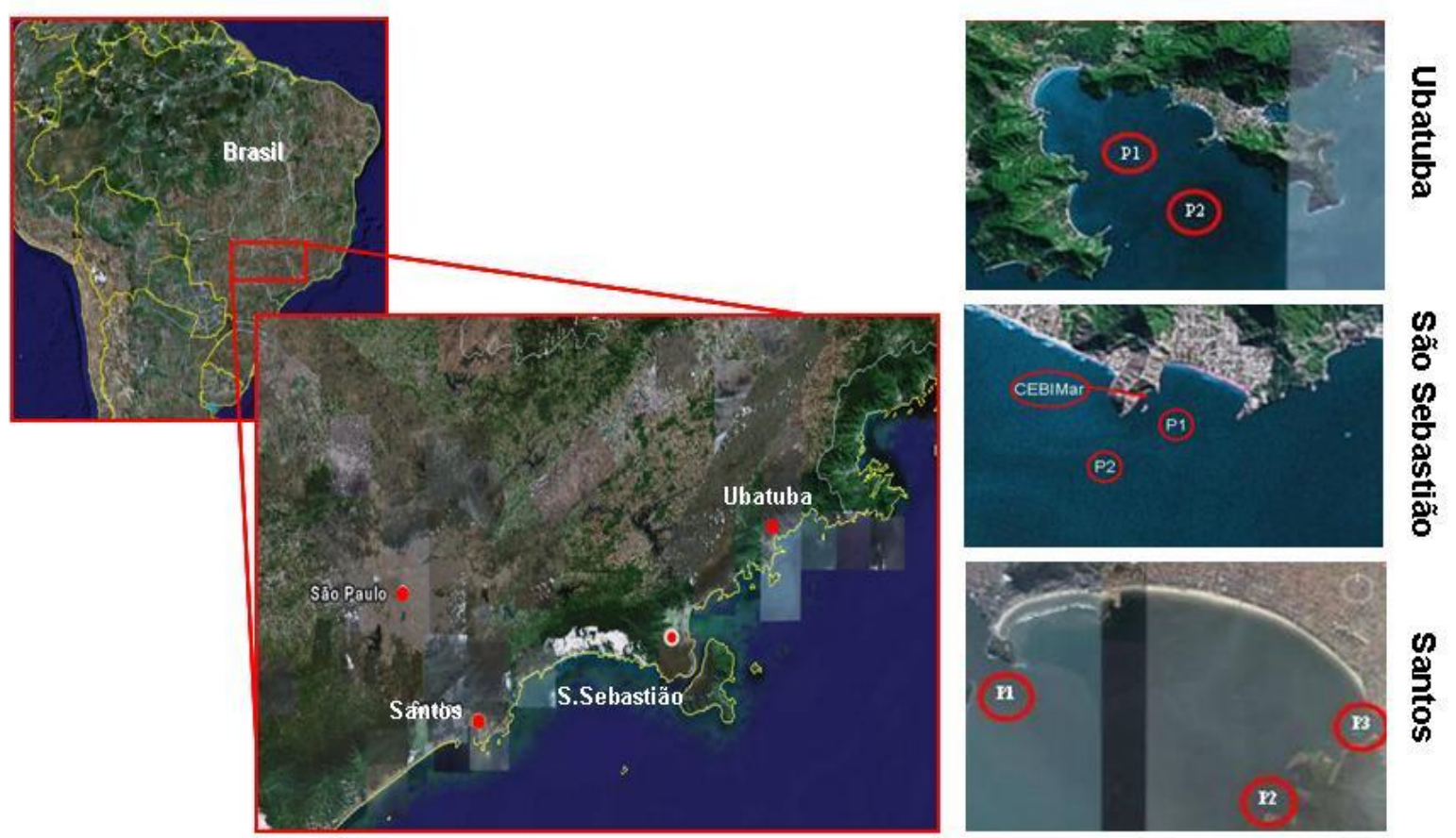

电

Figura 7 - Localização dos pontos de coleta de amostras em Ubatuba, Canal de São Sebastião e Baixada Santista FONTE: Google Earth.

\subsubsection{Tipos de amostras coletadas}

Água do mar: Em cada ponto, foram coletados 5 litros de água do mar, a dez centímetros abaixo da superfície, em frascos previamente esterilizados.

Plâncton: As amostras de plâncton foram coletadas utilizando rede de malha de $64 \mu \mathrm{m}$, por arraste, durante 5 minutos nos mesmos pontos de coleta das amostras de água e, em seguida, foram armazenadas em frascos de $250 \mathrm{~mL}$ previamente esterilizados.

As amostras foram transportadas sob refrigeração para o Laboratório de Microbiologia Ambiental/ICB II/USP e analisadas no prazo máximo de 24 horas. 


\subsubsection{Parâmetros físico-químicos}

No momento da coleta foram determinados os valores de salinidade, temperatura, condutividade e $\mathrm{pH}$ das amostras de água do mar, utilizando um equipamento de multiparâmetros HACH CO150 (Hach Company).

\subsection{PAdRonizaÇÃo do MEIO DE CULTURA PARA O CRESCIMENTO DE BACTÉRIAS QUITINOLÍTICAS}

\subsubsection{Seleção do método de obtenção de quitina coloidal}

Foram testadas três metodologias de preparação de quitina coloidal, conforme descrito abaixo:

a) Metodologia 1 (SKUJINS et al., 1965) - Foram adicionados 05 gramas de quitina de carapaças de caranguejo (Sigma-Aldrich) e $60 \mathrm{~mL}$ de $\mathrm{HCl}$ fumegante 37\% (Merck S.A.) em um frasco Erlenmeyer, o qual ficou sob agitação (250 rpm) por 01 hora a 24 ${ }^{\circ} \mathrm{C}$ e o produto obtido foi filtrado em lã de vidro. Posteriormente, foram adicionados $200 \mathrm{~mL}$ de solução aquosa de etanol absoluto a 50\% (Merck). A mistura foi homogeneizada vigorosamente e transferida para um funil de vidro contendo papel de filtro $(80 \mathrm{~g}-60 \times 60 \mathrm{~cm}$ ). O produto obtido foi lavado com cinco litros de água destilada estéril até chegar ao $\mathrm{pH}$ 7.0. A quitina coloidal formada foi transferida para um recipiente de vidro estéril e armazenada no escuro a $4{ }^{\circ} \mathrm{C}$.

b) Metodologia 2 (ROBERTS e SELITRENNIKOF, 1988 modificado por WEN et al., 2002) - Em um frasco Erlenmeyer foram adicionados 05 gramas de quitina de carapaças de caranguejo (Sigma-Aldrich) e $60 \mathrm{~mL}$ de $\mathrm{HCl}$ fumegante 37\% (Merck), e em seguida o frasco foi colocado sob agitação $(250 \mathrm{rpm})$ a $24{ }^{\circ} \mathrm{C}$ por 24 horas. Após esse período, foram adicionados $200 \mathrm{~mL}$ de etanol absoluto (Merck) e novamente colocado sob agitação $(250 \mathrm{rpm})$ a $24{ }^{\circ} \mathrm{C}$ por 24 horas. O produto obtido foi centrifugado a $5000 \mathrm{~g}$ por 20 minutos a $4{ }^{\circ} \mathrm{C}$ e o precipitado foi transferido para um funil de vidro contendo papel de filtro $(80 \mathrm{~g}-60$ x $60 \mathrm{~cm})$ onde foi necessário adicionar 8 litros de água destilada estéril para que o $\mathrm{pH}$ atingisse o valor de 7.0. A 
quitina coloidal formada foi transferida para um recipiente de vidro estéril e armazenada no escuro a $4{ }^{\circ} \mathrm{C}$.

c) Metodologia 3 (YABUKI et al., 1986) - Em um frasco Erlenmeyer foram adicionadas 05 gramas de quitina de carapaças de caranguejo (Sigma-Aldrich) e $40 \mathrm{~mL}$ de $\mathrm{NaOH}$ $1 \mathrm{~N}$ (gelado) e em seguida, foi colocado a $4{ }^{\circ} \mathrm{C}$ por 24 horas. Após esse período, a mistura de $\mathrm{NaOH}$ e quitina foi transferida para um funil de vidro contendo papel de filtro e foi lavada com 1 litro de água destilada estéril. Em seguida, em um novo frasco Erlenmeyer, foi adicionado à mistura $40 \mathrm{~mL}$ de $\mathrm{HCl} 1 \mathrm{~N}$ e esta foi colocada sob agitação $(250 \mathrm{rpm})$ por 24 horas a $24{ }^{\circ} \mathrm{C}$. A solução foi transferida para um funil de vidro com um papel de filtro $(80 \mathrm{~g}-60$ x $60 \mathrm{~cm}$ ) e foi lavada com 2 litros de água destilada estéril. Em seguida, acrescentou-se $10 \mathrm{~mL}$ de $\mathrm{HCl} 0,1 \mathrm{~N}$ ao produto formado e o pH foi ajustado em $7.0 \mathrm{com} \mathrm{NaOH} 1 \mathrm{~N}$. O produto final foi transferido para um recipiente de vidro estéril e armazenado no escuro a $4{ }^{\circ} \mathrm{C}$.

\subsubsection{Preparação de Meio Mínimo (MM)}

O meio mínimo foi preparado como descrito por Furukawa et al. (1978).

\subsubsection{Avaliação do Meio Mínimo (MM) com quitina coloidal}

Foi adicionado separadamente 1,2\% de quitina coloidal (PARK et al., 2000), preparada de acordo com a metodologia 1 e metodologia 2, ao meio mínimo descrito por Furukawa et al. (1978). Os dois meios de cultura foram aqui denominados MMQ1 (Meio Mínimo contendo Quitina coloidal preparada de acordo com a metodologia 1) e MMQ2 (Meio Mínimo contendo Quitina coloidal preparada de acordo com a metodologia 2).

\subsubsection{Cepas Controle}

Cepas da família Vibrionaceae (Tabela 1) foram inoculadas em MMQ1 e MMQ2 para verificar se esses meios de cultura possibilitavam o crescimento e a visualização do halo de hidrólise de quitina produzido por essas cepas. 
Tabela 1 - Cepas utilizadas para verificar a atividade de quitinase extracelular em meio mineral contendo quitina coloidal preparada de acordo com as metodologias 1 e 2 .

\begin{tabular}{|c|c|c|c|}
\hline Espécie & Cepa $n^{\circ}$ & $\begin{array}{c}\text { Outras designações e/ou } \\
\text { informações }\end{array}$ & Referência \\
\hline Vibrio mimicus & $\mathrm{RC} 55$ & $\begin{array}{c}\text { Isolado Ambiental; Louisiana - } \\
\text { EUA }\end{array}$ & Rivera et al., 2001 \\
\hline Vibrio mimicus & $\mathrm{RC} 57$ & $\begin{array}{l}\text { Isolado Ambiental; Louisiana, } \\
\text { West Bay - EUA }\end{array}$ & Rivera et al., 2001 \\
\hline Vibrio cholerae Não-O1 & RC60 & $\begin{array}{c}\text { Isolado Ambiental; Sedimento, } \\
\text { Brasil - } 1996\end{array}$ & Rivera et al., 2001 \\
\hline Vibrio cholerae Não-O1 & $\mathrm{RC70}$ & $\begin{array}{l}\text { Isolado Ambiental; Sedimento } \\
\text { Marinho, Brasil - } 1983\end{array}$ & Rivera et al., 2001 \\
\hline Vibrio fluvialis & ATCC 33809 & Cepa Padrão & ATCC \\
\hline Vibrio proteolyticus & ATCC 15338 & Cepa Padrão & ATCC \\
\hline Vibrio splendidus & ATCC 33125 & Cepa Padrão & ATCC \\
\hline
\end{tabular}

\subsubsection{Amostras de Água do Mar e Plâncton}

Nas primeiras 18 amostras de água do mar (08 do Canal de São Sebastião, 06 da Baixada Santista e 04 de Ubatuba) e 14 amostras de plâncton (06 do Canal de São Sebastião, 06 da Baixada Santista e 02 de Ubatuba) foram testados os meios MMQ1 e MMQ2 para verificar qual desses dois meios possibilitava o isolamento de maior número de bactérias quitinolíticas. Porém, posteriormente, apenas o MMQ1 foi utilizado para contagem de bactérias quitinolíticas. 


\subsection{ANÁLISES MICROBIOLÓGICAS}

\subsubsection{Contagem em placas de bactérias quitinolíticas}

Amostras de água: A quantificação de bactérias quitinolíticas foi feita pela técnica de contagem em placa por semeadura em profundidade (Pour Plate), utilizando MMQ1 ágar. Todas as análises foram feitas em duplicata.

Amostras de plâncton: Um grama de plâncton (peso úmido), de cada amostra, foi macerado em um triturador de tecidos e em seguida, foram feitas diluições em água de diluição na proporção de 1:10, 1:100 e 1:1000 (APHA, 1998). Foi transferido $01 \mathrm{~mL}$ de cada diluição para placas de petri estéreis e, a seguir, adicionou-se o MMQ1 ágar conforme a técnica de semeadura em profundidade (Pour Plate).

Todas as placas contendo foram incubadas a $27 \pm 2{ }^{\circ} \mathrm{C}$ por um período de até 07 dias. As colônias que apresentaram halo de hidrólise de quitina foram consideradas bactérias quitinolíticas e foram contadas. Adicionalmente, as colônias que cresceram nas mesmas placas, mas não apresentaram halo de hidrólise de quitina (CSH - Colônias sem halo) também foram contadas. Aproximadamente 05 colônias de cada tipo de amostra que apresentaram halo de hidrólise foram selecionadas e transferidas para tubos de ensaio contendo MMQ1 ágar inclinado.

\subsubsection{Determinação da qualidade microbiológica das amostras de água do mar}

Para avaliar a qualidade microbiológica das amostras de água foram realizadas as contagens de Coliformes Termotolerantes (CT), Escherichia coli e Enterococos intestinais (EI) utilizando a metodologia descrita pela APHA (1998).

\subsection{CARACTERIZAÇÃO FENOTÍPICA DAS BACTÉRIAS QUITINOLÍTICAS}

\subsubsection{Reisolamento e determinação do tempo de incubação para formação de halo de hidrólise de quitina}

Todas as bactérias quitinolíticas selecionadas foram semeadas por estriamento em MMQ1 ágar, incubados a $27 \pm 2{ }^{\circ} \mathrm{C}$ e observadas diariamente até o surgimento do halo de 
hidrólise de quitina. Posteriormente, elas foram submetidas à coloração de Gram e em seguida ao teste do KOH para confirmar o resultado obtido pela coloração de Gram (BUCK, 1982).

\subsubsection{Avaliação da degradação de quitina em meio sólido}

As bactérias quitinolíticas, novamente, foram semeadas por estriamento em MMQ1 ágar e incubadas a $27 \pm 2{ }^{\circ} \mathrm{C}$. O halo de hidrólise de quitina das bactérias gram-negativas e das gram-positivas (excluindo os gram-positivos filamentosos) foi medido com 96 horas de incubação e a medida do halo de hidrólise dos isolados gram-positivos filamentosos foi realizada com 168 horas de incubação, de acordo com o resultado obtido no experimento anterior (Item 4.5.1). As cepas padrão RC55 ( V. mimicus), RC57 (V. mimicus), RC60 ( $V$. cholerae), RC70 (V. cholerae), ATCC33809 (V. fluvialis), ATCC15338 (V. proteolyticus) e ATCC33125 (V. splendidus) (Tabela 1) também foram semeadas em MMQ1 ágar, incubadas a $27 \pm 2{ }^{\circ} \mathrm{C}$ e utilizadas como controles positivos nos experimentos de degradação de quitina coloidal em meio sólido.

A medida do halo foi obtida com o auxílio de um paquímetro digital e foi realizada uma medição no sentido vertical (Y1) e uma no sentido horizontal (Y2). A medida do halo correspondeu à média desses dois valores descontada a medida da colônia no sentido vertical (X1) e horizontal (X2), ou seja: $\mathrm{M}_{\text {halo }}:[(\mathrm{Y} 1-\mathrm{X} 1)+(\mathrm{Y} 2-\mathrm{X} 2)] / 2$. O mesmo procedimento foi realizado em três colônias/halos de cada isolado e o resultado final foi a média da medida do halo $\left(\mathrm{M}_{\text {halo }}\right)$ dos três valores encontrados (Figura 8). 


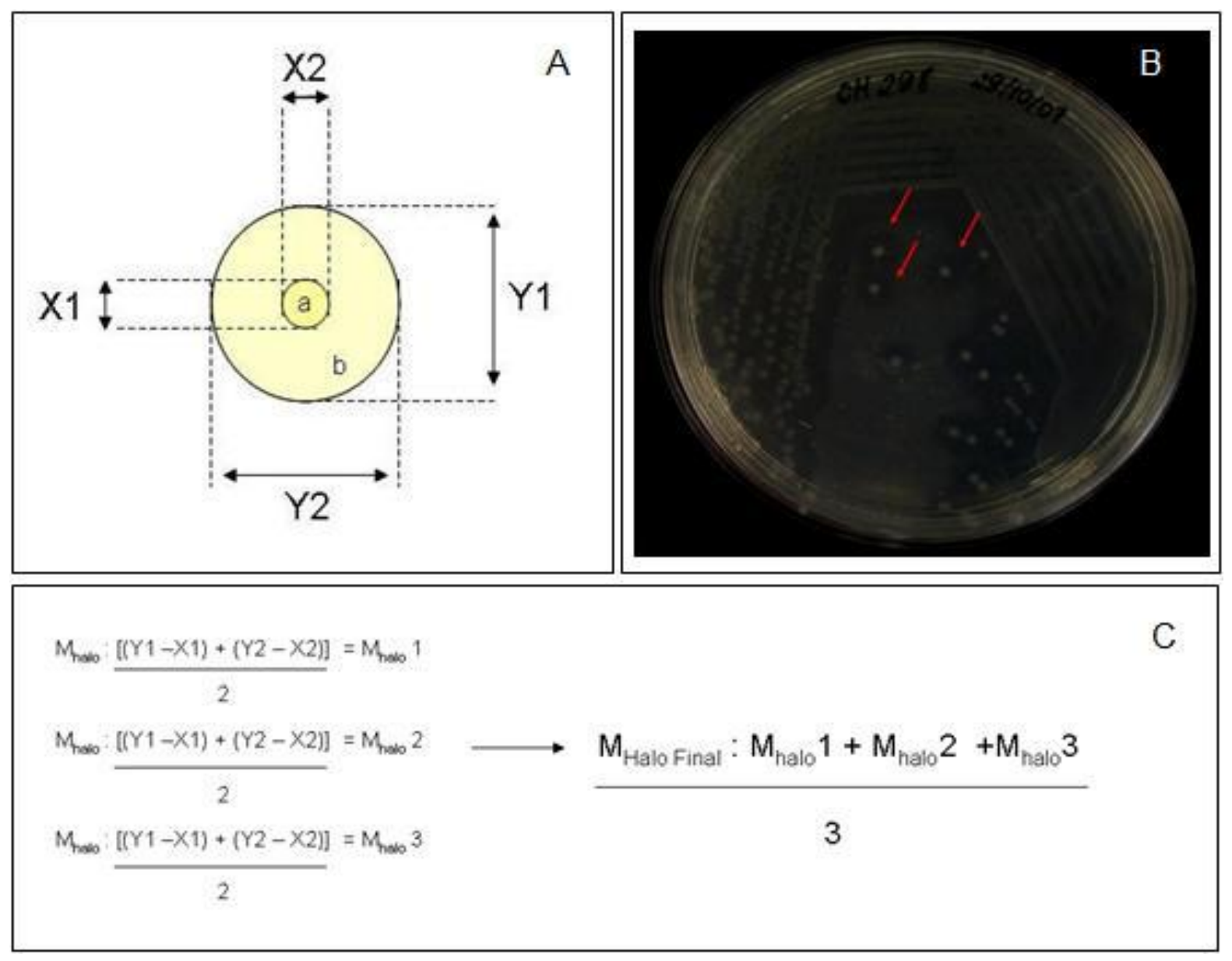

Figura 8 - Medida do halo de hidrólise de quitina produzido pelas bactérias quitinolíticas em MMQ1. A: Representação esquemática dos locais de medida do halo e da colônia (a: colônia; b: halo). B: Foto de uma placa com um isolado quitinolítico mostrando as três colônias/halo selecionadas para a realização da medida. C: Fórmula matemática utilizada para obter a medida final do halo de hidrólise de cada isolado.

\subsubsection{Quantificação de atividade enzimática através da liberação de $N$-acetil-glicosamina (GlcNAc)}

A atividade enzimática total foi determinada pela quantificação de $\mathrm{N}$-acetilglicosamina (GlcNAc) formada a partir da degradação de quitina coloidal conforme descrito por Ulhoa (1991) e modificado por Barreto (1995). A quitina coloidal (5 mg . $\mathrm{mL}^{-1}$ ) preparada de acordo com metodologia 1 (Item 4.3.1.) foi utilizada como substrato da reação.

As bactérias quitinolíticas foram inoculadas em $10 \mathrm{~mL}$ de caldo MMQ1 e incubadas a $27 \pm 2{ }^{\circ} \mathrm{C}$ sob agitação constante $(250 \mathrm{rpm})$ por 96 horas (gram-negativos e bacilos/cocos gram-positivos) e 168 horas (gram-positivos filamentosos). Após o período de incubação, as 
culturas foram centrifugadas a 3.000 g por 5 minutos a $27{ }^{\circ} \mathrm{C}$. Em um tubo de micro

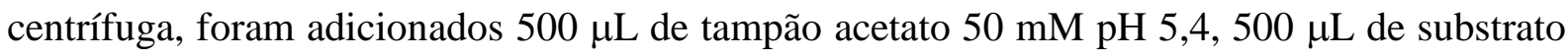
$\left(5 \mathrm{mg} \cdot \mathrm{mL}^{-1}\right)$ e $250 \mu \mathrm{L}$ do sobrenadante da cultura a ser analisada. A incubação foi realizada a $37^{\circ} \mathrm{C}$, por 5 horas em banho-maria com agitação branda.

Em seguida, a quantidade de $N$-acetil-glicosamina (GlcNAc) formada foi medida colorimetricamente de acordo com a metodologia descrita por Reissig et al. (1955) e modificado por Barreto (1995). Do volume final de 1,25 mL de reação foram retirados 170 $\mu \mathrm{L}$ e transferidos para outro tubo contendo $30 \mu \mathrm{L}$ de tetraborato de potássio $0,8 \mathrm{M} \mathrm{pH} \mathrm{9,1.} \mathrm{A}$ mistura foi fervida durante 3 minutos e após ser resfriada a temperatura ambiente, foi adicionado ao tubo 1,0 mL de solução de $p$-dimetilaminobenzaldeído (DMAB 1\% (p/v) / HCl $1,25 \%$ (v/v) dissolvidos em ácido acético). $\mathrm{O}$ tubo foi incubado a $37^{\circ} \mathrm{C}$ por 10 minutos e após isso foi feita a leitura da absorbância a $540 \mathrm{~nm}$. Todos os ensaios foram realizados em duplicata e, a cada experimento, foram adicionados os seguintes controles: branco da reação (excluindo somente o substrato), branco total (contendo tampão e água), branco do substrato (excluindo apenas a amostra) e como controle positivo foi utilizada uma solução de quitinase de Trichoderma viride à concentração de $0,2 \mathrm{mg} \cdot \mathrm{mL}^{-1}$.

Uma unidade (U) foi definida como a quantidade de enzima necessária para formar 1,0 $\mu$ mol de GlcNAc por minuto por $\mathrm{mL} \mathrm{a} 37^{\circ} \mathrm{C}$.

$$
\mathrm{U}=\mu \mathrm{mol} \text { GlcNAc } \cdot \mathrm{min}^{-1} \cdot \mathrm{mL}^{-1}
$$

A curva padrão foi construída utilizando concentrações de 0,05 a $1 \mathrm{mg}$ de $N$-acetilglicosamina (Sigma-Aldrich) dissolvida em tampão acetato $50 \mathrm{mM} \mathrm{pH} \mathrm{5,4} \mathrm{e} \mathrm{em} \mathrm{seguida} \mathrm{foi}$ realizado o protocolo descrito por Reissig et al. (1955) e modificado por Barreto (1995), conforme descrito acima.

\subsubsection{Quantificação de $\beta$ - $N$-acetil-glicosaminidase, Quitobiosidase e Endoquitinase}

As culturas de bactérias quitinolíticas foram obtidas como descrito no item 4.5.3 e após o período de incubação, as culturas foram centrifugadas a 3.000 g por 5 minutos a $27^{\circ} \mathrm{C}$ para recuperar as enzimas quitinolíticas presentes no sobrenadante da cultura.

A quantificação das enzimas quitinolíticas: Quitobiosidase, $\beta-N$-acetil-glicosaminidase e Endoquitinase foi realizada em duplicata utilizando o Chitinase Assay Kit (Sigma-Aldrich) 
seguindo as instruções do fabricante. Os ensaios foram realizados em duplicata e em cada experimento foi incluído um controle negativo (somente substrato para detecção da enzima) e um controle positivo (quitinase de Trichoderma viride à concentração de $0,01 \mathrm{mg} \cdot \mathrm{mL}^{-1}$ ). Uma unidade (U) foi definida como a quantidade necessária para liberar 1,0 $\mu$ mol de $p$ nitrofenol por minuto a um $\mathrm{pH} 4.8$ por $\mathrm{mL}$ a $37^{\circ} \mathrm{C}$.

$$
\mathrm{U}=\mu \mathrm{mol} p \text {-nitrofenol } \cdot \mathrm{min}^{-1} \cdot \mathrm{mL}^{-1}
$$

\subsection{CARACTERIZAÇÃO MOLECULAR DAS BACTÉRIAS QUITINOLÍTICAS}

\subsubsection{Extração de DNA genômico}

A extração de DNA genômico das bactérias quitinolíticas foi realizada com $o$ Kit Wizard $^{\circledR}$ Genomic DNA Purification (A1125, Promega Co., EUA), de acordo com as instruções do fabricante.

A concentração e a pureza do DNA de cada amostra foram determinadas através de eletroforese em gel de agarose a 0,8\% em tampão TAE 1X (Tris-acetato 0,04 mM; EDTA 0,001M, pH 8,0) e em espectrofotômetro (NanoDrop® ND 1000) (SAMBROOK, et al., 1989).

\subsubsection{Caracterização molecular pelas técnicas de ERIC-PCR e BOX-PCR}

O DNA de cada bactéria foi submetido às técnicas de BOX-PCR (Reação em cadeia pela Polimerase utilizando sequências Modulares Repetitivas) e ERIC-PCR (Reação em Cadeia pela Polimerase utilizando Sequências Intergênicas Repetitivas em Enterobactérias), ambas descritas por Versalovic et al. (1991), sendo que a técnica de ERIC-PCR foi realizada utilizando apenas o iniciador ERIC 2. As sequências dos iniciadores e os ciclos de amplificação estão descritos na tabela 2 : 
Tabela 2 - Iniciadores e condições de amplificação utilizada nas reações de BOX e ERIC-PCR.

\begin{tabular}{|c|c|c|}
\hline Iniciadores & Seqüîncia & Ciclos de amplificação \\
\hline BOX A1 & 5' CTA CGG CAA GGC GAC GCT GAC G 3' & $\begin{array}{c}94^{\circ} \mathrm{C}-5^{\prime} / 35 \text { ciclos }\left(94^{\circ} \mathrm{C}-1^{\prime} / 55^{\circ} \mathrm{C}-\right. \\
\left.1^{\prime} / 72^{\circ} \mathrm{C}-3^{\prime}\right) 72^{\circ} \mathrm{C}-15^{\prime}\end{array}$ \\
\hline ERIC 2 & 5`AAG TAA GTG ACT GGG GTG AGC G 3` & $\begin{array}{c}95^{\circ} \mathrm{C}-5^{\prime} / 30 \text { ciclos }\left(92^{\circ} \mathrm{C}-45^{\prime \prime} / 54^{\circ} \mathrm{C}-\right. \\
\left.1^{\prime} / 70^{\circ} \mathrm{C}-10^{\prime}\right) 70^{\circ} \mathrm{C}-20^{\prime}\end{array}$ \\
\hline
\end{tabular}

As reações de BOX e ERIC-PCR foram realizadas em um volume final de $25 \mu \mathrm{L}$, sendo 5,0 $\mu \mathrm{L}$ de solução tampão $1 \mathrm{X}\left(\mathrm{MgCl}_{2}\right.$ a $\left.1.5 \mathrm{mM}\right)$ (Colorless Go Taq ${ }^{T M}$ Reaction Buffer - Promega), 2,0 $\mu \mathrm{L}$ de solução mix de dNTPs a 2,5 mM (Promega), 2,0 $\mu \mathrm{L}$ do iniciador (BOX A1 ou ERIC2) a $20 \mu \mathrm{M}$ (IDT - Integrated DNA Technologies), $0,125 \mu \mathrm{L}$ da enzima GoTaq ${ }^{\circledR}$ DNA Polimerase (Promega), 14,88 $\mu \mathrm{L}$ de água ultra pura e $1 \mu \mathrm{L}$ de DNA (100 ng/uL).

Em todas as reações de PCR foram incluídas cepas padrão da coleção de cultura do Laboratório de Ecologia Microbiana Molecular do ICB/USP, sendo que as cepas RC11 ( $V$. cholerae O1), RC230 (V. cholerae O1 Inaba) e 569B (V. cholerae O1) foram utilizadas como controles positivos nas reações de ERIC-PCR e as cepas RC08 ( $V$. cholerae O1) e 569B ( $V$. cholerae $\mathrm{O} 1)$ nas reações de BOX-PCR. Em todas as reações foi utilizada água ultra pura como controle negativo, em substituição ao DNA.

Após a amplificação, $15 \mu \mathrm{L}$ da reação de PCR foram avaliados por eletroforese em gel de agarose (Invitrogen) 1,0\% (p/v), em tampão TAE $1 \mathrm{X}$ a $75 \mathrm{~V}$ por 90 minutos. Em cada gel, foi utilizado como marcador de peso molecular o Lambda DNA/Hind III (Promega). Os géis foram corados em solução de brometo de etídio $(0,5 \mu \mathrm{g} / \mathrm{mL})$ e fotografados no sistema de fotodocumentação Eagle Eye II (Stratagene).

\subsubsection{Sequenciamento parcial da região $16 \mathrm{~S}$ rRNA}

\subsubsection{Amplificação parcial da região 16S rRNA das bactérias quitinolíticas}

A amplificação da região $16 \mathrm{~S}$ rRNA dos isolados quitinolíticos foi realizada utilizando os iniciadores 27F (5' AGA GTT TGA TCM TGG CTC AG 3') e 1041R (5'CGG TGT GTA 
CAA GAC CC3 3'), descritos por Lane (1991) e Nubel et al. (1996), respectivamente. Na sequência nucleotídica dos iniciadores o $\mathrm{M}$ indica $\mathrm{A}$ ou $\mathrm{C}$.

As reações foram feitas em um volume final de $100 \mu \mathrm{L}$, sendo $10 \mu \mathrm{L}$ de solução tampão 10X (Invitrogen), 3,0 $\mu \mathrm{L}$ de $\mathrm{MgCl}_{2}$ a $50 \mathrm{mM}$ (Invitrogen), $0,4 \mu \mathrm{L}$ de solução mix de dNTPs a 2,0 mM (Invitrogen), 2,0 $\mu \mathrm{L}$ da solução de cada iniciador a $20 \mu \mathrm{M}$ (Invitrogen), 0,8 $\mu \mathrm{L}$ da enzima Taq polimerase (Invitrogen), 79,80 $\mu \mathrm{L}$ de água ultra pura e 2,0 $\mu \mathrm{L}$ de DNA (50 $\mathrm{ng} / \mu \mathrm{L}$ ). Em todas as reações foi utilizado o DNA de E. coli (ATCC 25922) como controle positivo e água ultra pura, em substituição ao DNA, como controle negativo.

A reação de amplificação foi realizada em termociclador (Mastercycler ep Gradient $S$ - Eppendorf) com as seguintes condições de amplificação: desnaturação inicial a $95{ }^{\circ} \mathrm{C}$ por 2 minutos, seguindo-se 30 ciclos de amplificação $\left(94{ }^{\circ} \mathrm{C}\right.$ por 2 minutos/ $55{ }^{\circ} \mathrm{C}$ por 1 minuto/ $72{ }^{\circ} \mathrm{C}$ por 3 minutos) e uma extensão final a $72{ }^{\circ} \mathrm{C}$ por 10 minutos.

O fragmento de DNA amplificado foi visualizado por eletroforese em gel de agarose $1,0 \%(\mathrm{p} / \mathrm{v})$, juntamente com os marcadores de peso molecular Lambda DNA/Hind III (Promega) e $1 \mathrm{~Kb}$ (Promega). Os géis foram corados em solução de brometo de etídio (0,5 $\mu \mathrm{g} / \mathrm{mL}$ ) e fotografados no sistema de fotodocumentação Eagle Eye II (Stratagene).

\subsubsection{Purificação e sequenciamento do fragmento do 16S rRNA amplificado}

Os produtos das reações de $16 \mathrm{~S}$ rRNA dos isolados quitinolíticos foram purificados com o Ilustra GFX ${ }^{\mathrm{TM}}$ PCR DNA and Gel Band Purification kit (28-9034-70, GE Healthcare) e eluídos em $30 \mu \mathrm{L}$ de água ultra pura.

Após a purificação, 1,0 $\mu \mathrm{L}$ da reação de PCR purificada, juntamente com os marcadores de peso molecular Lambda DNA/Hind III (Promega) e Ladder $1 \mathrm{~Kb}$ (Promega), foram submetidos à eletroforese horizontal em gel de agarose (Invitrogen) 1,0\% (p/v), em tampão TAE 1X a $75 \mathrm{~V}$ por 90 minutos. O gel foi corado em solução de Brometo de etídio $(0,5 \mu \mathrm{g} / \mathrm{mL})$ e fotografado no sistema de fotodocumentação Eagle Eye II (Stratagene).

Posteriormente, $3,0 \mu \mathrm{L}$ do produto de PCR (80 ng) foram utilizados na reação de amplificação com DYEnamic $^{\mathrm{TM}}$ ET Dye Terminator Cycle Sequencing Kit for MegaBAce DNA Analysis Systems (GE Healthcare) conforme instruções do fabricante e de acordo com o protocolo utilizado no Centro de Estudos do Genoma Humano/USP utilizando o iniciador 1041R (5' CGG TGT GTA CAA GAC CC 3') (NUBEL et al., 1996). Os produtos foram 
sequenciados no sequenciador automático MegaBace 1000 DNA Analysis System (Amersham Biosciences).

\subsection{ANÁLISE DOS RESULTADOS}

\subsubsection{Análises Estatísticas}

As variáveis analisadas foram inicialmente confrontadas com a curva de Gauss (Curva Normal) através do teste de Kolmogorov-Smirnov e teste de Shapiro-Wilk e classificadas em paramétricas e não paramétricas. Quando as variáveis foram consideradas paramétricas, estas foram descritas na forma de média e desvio padrão. As variáveis que foram consideradas não paramétricas foram descritas na forma de mediana e percentis 25 e 75 utilizando o método de Tukey's Hinges e os resultados foram apresentados na forma de gráficos box plot. As contagens de bactérias quitinolíticas e CSH em amostras de água do mar foram transformadas em UFC/100 mL para comparação estatística com as contagens de indicadores de contaminação fecal e são apresentadas dessa forma apenas nos gráficos box plot.

O teste de Mann-Whitney foi utilizado para comparar dois grupos entre si. Quando mais de duas variáveis não-paramétricas foram comparadas foi utilizado o teste de KruskalWallis, seguido pelo pós-teste de contraste de Müller-Dunn quando houve diferenças estatisticamente significantes entre as variáveis comparadas pelo teste de Kruskal-Wallis. As diferenças entre as contagens de bactérias quitinolíticas e CSH (Colônias sem halo de hidrólise de quitina) foram analisadas pelo teste de Postos Sinalizados de Wilcoxon. Foi admitida significância estatística para valores de $\mathrm{p} \leq 0,05$.

A Análise de Correlação de Spearman foi aplicada para verificar o grau de relacionamento entre as contagens de bactérias quitinolíticas e as contagens dos indicadores de contaminação fecal. Enquanto que a Análise de Correlação de Pearson foi utilizada para verificar o grau de relacionamento entre as variáveis físico-químicas e as contagens de bactérias quitinolíticas. Nessas análises, os resultados que apresentaram valores de $\mathrm{p} \leq 0,05 \mathrm{e}$ r entre 0 e 1 foram considerados estatisticamente significantes. 


\subsubsection{Análises dos agrupamentos obtidos pelas técnicas de ERIC-PCR e BOX-PCR}

Os perfis genéticos obtidos pelas técnicas de ERIC-PCR e BOX-PCR foram analisados pelo programa Bionumerics (Applied Maths), versão 5.00. A matriz de similaridade genética entre os isolados foi construída utilizando o Coeficiente de Dice e Jaccard separadamente e os agrupamentos foram realizados utilizando o algoritmo UPGMA (Unweighted Pair Group Method with Arithmetic mean). Foi utilizado o valor de 1\% de posição de tolerância de bandas (band position tolerance) para comparação dos fragmentos.

\subsubsection{Análises das sequências obtidas pelo sequenciamento parcial da região 16S rRNA}

As sequências nucleotídicas tiveram seus cromatogramas analisados e posteriormente foram editadas e alinhadas no programa BioEdit Sequence Alignment Editor (version 7.0.9.0) (HALL, 1999). Após a edição, as sequências obtidas (aproximadamente 500 pb) foram comparadas com sequências disponibilizadas no Ribosomal Database Project (RDP) do Center for Microbial Ecology - Michigan State University utilizando o algoritmo SeqMatch. Adicionalmente, as sequências obtidas também foram comparadas com as sequências presentes no banco de dados GenBank do Centro Nacional de Informação Biotecnológica NCBI (National Center for Biotechnology Information - NCBI), utilizando o algoritmo BlastN (ALTSCHUL et al., 1990).

As bactérias quitinolíticas que apresentaram o mesmo gênero ao serem comparadas com sequências disponibilizadas no RDP (Ribosomal Database Project) foram alinhadas utilizando o programa BioEdit e quando as bactérias apresentaram > 99\% de identidade (Sequence Identity Matrix) entre si, apenas uma bactéria foi selecionada como representante para a construção da árvore filogenética.

Após o alinhamento das sequências obtidas e das sequências referências selecionadas no RDP, as árvores filogenéticas foram construída com a utilização do programa MEGA 4 (TAMURA et al., 2007) utilizando o algoritmo Neighbor-Joining (SAITOU e NEI, 1987), o

algoritmo Junkes-Cantor (JUNKES e CANTOR, 1969), e um valor de “bootstrap” de 1000 repetições. A cepa Methanocaldococcus jannaschii DSM 2661; L77117 foi utilizada como grupo externo na construção das árvores filogenéticas. 


\section{RESULTADOS}

\subsection{PAdRonizaÇÃo do MEIO DE CULTURA PARA O CRESCIMENTO DE BACTÉRIAS QUITINOLÍTICAS}

\subsubsection{Seleção do método de obtenção de quitina coloidal e preparação de Meio Mínimo}

(MM)

Foram analisadas três metodologias de preparação de quitina coloidal, as quais apresentavam diferenças nos reagentes utilizados e no período necessário para a obtenção da quitina coloidal, conforme pode ser observado na tabela 3.

Tabela 3 - Comparação das três metodologias utilizadas para preparação de quitina coloidal.

\begin{tabular}{|c|c|c|c|}
\hline \multirow{2}{*}{ Reagentes/Materiais } & \multicolumn{3}{|c|}{ Metodologias } \\
\hline & $\mathbf{1}^{*}$ & $2 * *$ & $3 * * *$ \\
\hline Quitina de Carapaças de Caranguejo & $05 \mathrm{~g}$ & $05 \mathrm{~g}$ & $05 \mathrm{~g}$ \\
\hline $\mathrm{HCl}$ fumegante $37 \%$ & $60 \mathrm{~mL}$ & $60 \mathrm{~mL}$ & - \\
\hline Lã de Vidro & Sim & Não & Não \\
\hline Centrífuga Refrigerada & Não & Sim & Não \\
\hline $\mathrm{NaOH} 1 \mathrm{~N}$ & - & - & $40 \mathrm{~mL}$ \\
\hline $\mathrm{HCl} 1 \mathrm{~N}$ & - & - & $40 \mathrm{~mL}$ \\
\hline $\mathrm{HCl} 0,1 \mathrm{~N}$ & - & - & $10 \mathrm{~mL}$ \\
\hline Etanol $50 \%$ & $200 \mathrm{~mL}$ & - & - \\
\hline Etanol Absoluto & - & $200 \mathrm{~mL}$ & - \\
\hline Água destilada & 05 litros & 08 litros & 03 litros \\
\hline Tempo de preparação & 06 horas & 03 dias & 03 dias \\
\hline Formação - Quitina Coloidal & Sim & Sim & Não \\
\hline Rendimento - Quitina coloidal (peso úmido) & $90 \mathrm{~g}$ & $120 \mathrm{~g}$ & - \\
\hline
\end{tabular}

Nota:

*: SKUJINS et al., 1965.

**: WEN et al., 2002.

***: YABUKI et al., 1986.

A quitina coloidal obtida ao final do experimento, proposto por Wen et al. (2002) (Metodologia 2), apresentou partículas de quitina não dissolvidas, visto que nessa metodologia não foi realizada a filtração em lã de vidro e sim uma centrifugação a 5000 g a $4{ }^{\circ} \mathrm{C}$ para recuperar a quitina após a dissolução com $\mathrm{HCl}$. $\mathrm{O}$ tempo de preparação da quitina 
coloidal, de acordo com as metodologias 2 e 3, foi muito maior em comparação com a metodologia 1. A metodologia 03 (YABUKI et al., 1986) não formou quitina coloidal após os três dias de preparação da quitina. Diante disso, somente a quitina coloidal obtida pelas metodologias 1 e 2 foi utilizada para preparação do meio de cultura.

Os meios MMQ1 (Meio Mínimo contendo Quitina coloidal preparada de acordo com a metodologia 1) e MMQ2 (Meio Mínimo contendo Quitina coloidal preparada de acordo com a metodologia 2) apresentaram um aspecto semitransparente, porém o MMQ2 continha partículas sólidas de quitina de vários tamanhos. Apesar disso, os dois meios de cultura possibilitaram o crescimento e visualização do halo de hidrólise de quitina de todas as cepas da família Vibrionaceae utilizadas nesse estudo (Tabela 1). Entretanto, a presença de partículas de quitina presentes no meio MMQ2 dificultou a visualização das colônias e dos halos.

Após a confirmação de que os meios MMQ1 e MMQ2 possibilitavam o crescimento bacteriano, estes foram testados com amostras de água do mar e plâncton e verificou-se que isolados quitinolíticos cresceram nos dois meios de cultura. No entanto, o MMQ1 permitiu uma melhor visualização das colônias e dos halos formados pelos isolados quitinolíticos provenientes de amostras ambientais em comparação com o MMQ2, visto que as partículas de quitina presentes no MMQ2 dificultaram a contagem e a visualização das colônias bacterianas e dos halos de hidrólise de quitina (Figura 9).
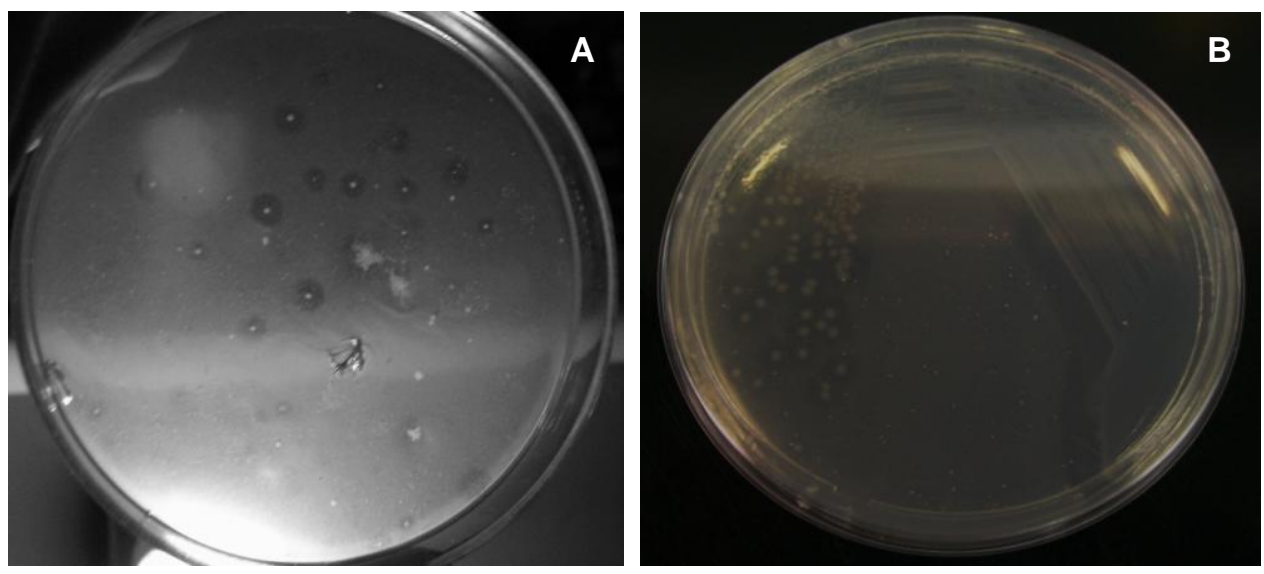

Figura 9 - Isolados quitinolíticos em placas contendo MMQ1 após incubação a $27 \pm 2{ }^{\circ} \mathrm{C}$ por 96 horas. A: Isolados quitinolíticos de uma amostra de água do mar. B: Vibrio proteolyticus (ATCC 15338). 
De acordo com as análises estatísticas realizadas (Wilcoxon signed rank test), o MMQ1 mostrou-se também mais eficiente para a obtenção de bactérias quitinolíticas em comparação com o MMQ2, tanto em amostras de água do mar $(\mathrm{p}=0,0002)$ quanto em amostras de plâncton $(\mathrm{p}=0,0001)$. O valor da mediana e do percentil 25 e 75 das contagens de bactérias quitinolíticas em 18 amostras de água do mar e 14 amostras de plâncton realizadas em placas de MMQ1 e MMQ2 pode ser observado na Figura 10.

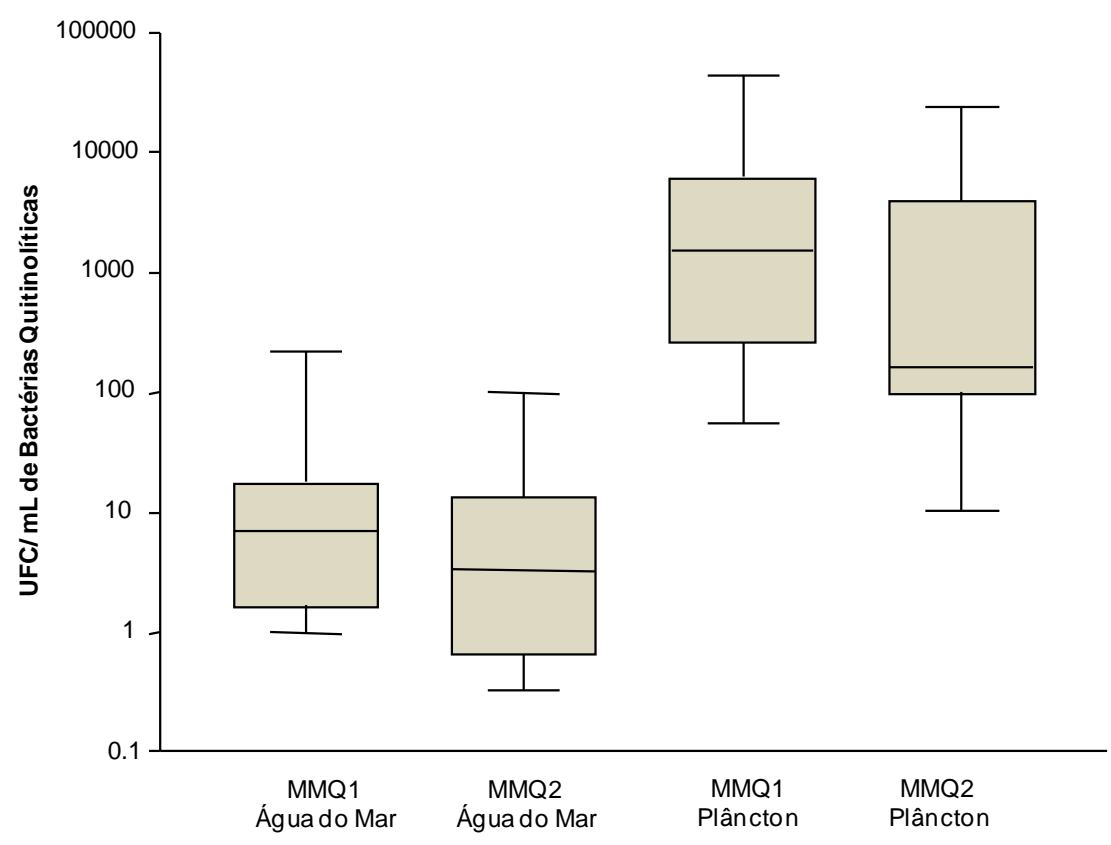

Figura 10 - Comparação das contagens de bactérias quitinolíticas em 18 amostras de água do mar e em 14 amostras de plâncton utilizando os meios de culturas MMQ1 e MMQ2.

Legenda:

\begin{tabular}{|l|l}
$\begin{array}{l}\text { Percentil75 } \\
\text { Mediana }\end{array}$ & Valor Máximo \\
Percentil25 & Valor mínimo
\end{tabular} 


\subsection{CARACTERIZAÇÃO FÍSICO-QUÍMICA E MICROBIOLÓGICA DOS TRÊS ECOSSISTEMAS MARINHOS ESTUDADOS}

\subsubsection{Parâmetros Físico-químicos e Indicadores de Contaminação Fecal em Amostras de Água do Mar}

$\mathrm{O}$ menor valor de temperatura, salinidade, $\mathrm{pH}$ e condutividade foi observado na Baixada Santista no mês de março de 2006. Em Ubatuba foi observado o maior valor de temperatura e condutividade em março de 2007 e março de 2006, respectivamente. O maior valor de salinidade foi observado no Canal de São Sebastião nos meses de setembro de 2005 e em fevereiro e março de 2007. Em janeiro de 2007, no Canal de São Sebastião foi observado o maior valor de $\mathrm{pH}$. Os valores mínimos, máximos, média aritmética e desvio padrão de temperatura, salinidade, $\mathrm{pH}$ e condutividade obtidos no Canal de São Sebastião, Ubatuba e Baixada Santista podem ser observados na tabela 4.

Tabela 4 - Valores mínimos, máximos, médias aritméticas e desvio padrão dos parâmetros físico-químicos obtidos em amostras de água do mar do litoral do estado de São Paulo.

\begin{tabular}{|c|c|c|c|c|c|c|c|c|c|c|c|c|c|c|c|c|c|}
\hline \multirow{2}{*}{ Local } & \multirow{2}{*}{$\mathrm{N}$} & \multicolumn{4}{|c|}{ Temperatura $\left({ }^{\circ} \mathbf{C}\right)$} & \multicolumn{4}{|c|}{ Salinidade (\%o) } & \multicolumn{4}{|c|}{$\mathrm{pH}$} & \multicolumn{4}{|c|}{ Condutividade (ms) } \\
\hline & & $\mathrm{m}$ & $\mathrm{M}$ & $\mathrm{MD}$ & $\mathrm{DP}$ & $\mathrm{m}$ & $\mathrm{M}$ & $\mathrm{MD}$ & $\mathrm{DP}$ & $\mathrm{m}$ & $\mathrm{M}$ & $\mathrm{MD}$ & $\mathrm{DP}$ & $\mathrm{m}$ & $\mathrm{M}$ & MD & $\mathrm{DP}$ \\
\hline $\begin{array}{l}\text { C. de São } \\
\text { Sebastião }\end{array}$ & 40 & 21,5 & 26,3 & 24,0 & 1,5 & 34,0 & 35,0 & 34,1 & 0,4 & 8,1 & 8,5 & 8,3 & 0,1 & 37,6 & 49,4 & 44,1 & 2,6 \\
\hline Ubatuba & 12 & 25,3 & 31,9 & 28,4 & 2,4 & 26,4 & 31,7 & 29,0 & 2,1 & 7,0 & 8,0 & 7,4 & 0,3 & 41 & 49,9 & 44,8 & 3,2 \\
\hline $\begin{array}{l}\text { Baixada } \\
\text { Santista }\end{array}$ & 21 & 19,6 & 28,5 & 24,0 & 2,6 & 19,7 & 31,8 & 26,0 & 4,4 & 6,5 & 8,0 & 7,2 & 0,4 & 31,8 & 48,8 & 40,4 & 6,2 \\
\hline
\end{tabular}

Legenda: N: número de amostras coletadas; m: valor mínimo; M: valor máximo; MD: média aritmética; DP: desvio padrão

As maiores e menores contagens de coliformes termotolerantes, Escherichia coli e Enterococos intestinais foram encontradas em amostras coletadas na Baixada Santista e em Ubatuba, respectivamente. As contagens desses três indicadores de contaminação fecal em cada ambiente marinho estudado foram expressas em mediana e percentil 25 e 75 (Figura 11). 

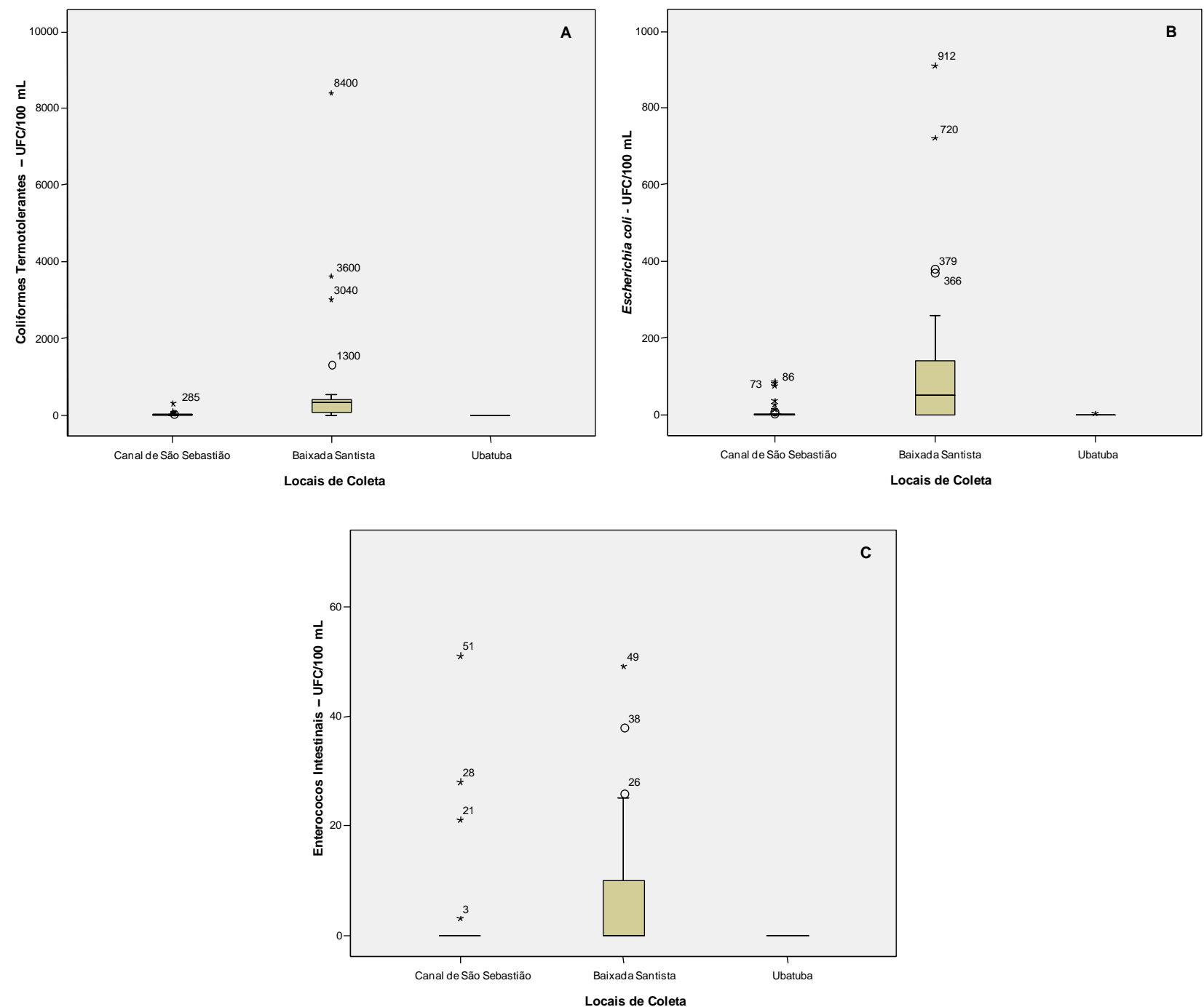

Figura 11 - Valor da mediana, percentil 25 e 75 das contagens dos indicadores de contaminação fecal nas amostras de água do mar coletadas no Canal de São Sebastião, Baixada Santista e Ubatuba. A: coliformes termotolerantes; B: Escherichia coli; C: enterococos intestinais Legenda:

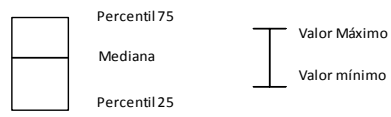

De acordo com o Teste de Mann-Whitney as diferenças nas contagens de coliformes termotolerantes $(\mathrm{p}=0,000)$, Escherichia coli $(\mathrm{p}=0,001)$ e enterococos intestinais $(\mathrm{p}=0,013)$ encontradas no Canal de São Sebastião e Baixada Santista foram estatisticamente significantes. Ao comparar as contagens dos indicadores de contaminação fecal obtidas no Canal de São Sebastião e Ubatuba, foram verificadas diferenças estatisticamente significantes apenas entre as contagens de coliforme termotolerantes $(p=0,002)$. E ainda, diferenças estatisticamente significantes também foram encontradas entre as contagens de coliformes 
termotolerantes $(p=0,000)$, Escherichia coli $(p=0,002)$ e enterococos intestinais $(p=0,006)$ obtidas de amostras de água do mar coletadas em Ubatuba e na Baixada Santista.

Nas amostras de água do Canal de São Sebastião foi observada correlação positiva entre as contagens de coliformes termotolerantes e enterococos intestinais $(p=0,002$ e $r=$ 0,465) e também entre Escherichia coli e enterococos intestinais ( $\mathrm{p}=0,01$ e $\mathrm{r}=0,499)$. Na Baixada Santista também foram encontradas correlações entre as contagens de coliformes termotolerantes e enterococos intestinais $(\mathrm{p}=0,036$ e $\mathrm{r}=0,460)$ e também entre Escherichia coli e enterococos intestinais $(\mathrm{p}=0,013$ e $\mathrm{r}=0,533)$. Nas amostras coletadas em Ubatuba não foi observada nenhuma correlação entre as contagens de indicadores de contaminação fecal.

Comparando os resultados de contagens dos indicadores de contaminação fecal com os valores físico-químicos encontrados em cada ambiente marinho estudado, verificou-se correlação $(p=0,02$ e r= - 0,365) apenas entre as contagens de Escherichia coli e os valores de pH encontrados no Canal de São Sebastião.

\subsubsection{Contagem de bactérias quitinolíticas viáveis}

As concentrações de bactérias quitinolíticas e colônias sem halo (CSH) em amostras de água do mar e plâncton foram determinadas diariamente. Porém, os resultados de contagens que serão apresentados no decorrer desse trabalho, correspondem ao número total de bactérias quitinolíticas e CSH presentes em MMQ1 no sétimo dia de incubação.

\subsubsection{Canal de São Sebastião}

As bactérias quitinolíticas estavam presentes em $75 \%$ das amostras de água do mar e em $100 \%$ das amostras de plâncton coletadas no Canal de São Sebastião. As contagens de $\mathrm{CSH}$ foram sempre maiores que as contagens de bactérias quitinolíticas tanto em amostras de água do mar como em plâncton (Tabela 5). O valor da mediana e do percentil 25 e 75 das contagens de bactérias quitinolíticas e CSH obtidas nos dois tipos de amostras, coletadas nos dois pontos de coleta do Canal de São Sebastião, são apresentados na Figura 12. 
Tabela 5 - Valores mínimos e máximos de bactérias quitinolíticas e CSH em amostras de água do mar e plâncton coletadas no Canal de São Sebastião.

\begin{tabular}{|c|c|c|c|c|c|c|c|}
\hline \multirow{3}{*}{ Amostras } & \multicolumn{7}{|c|}{ Canal de São Sebastião } \\
\hline & \multirow{2}{*}{ Parâmetro } & \multicolumn{3}{|c|}{ Ponto 01} & \multicolumn{3}{|c|}{ Ponto 02} \\
\hline & & $\mathrm{N}$ & $\mathrm{m}$ & M & $\mathrm{N}$ & $\mathrm{m}$ & M \\
\hline \multirow{2}{*}{ 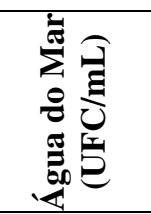 } & B. Quitinolíticas & \multirow[t]{2}{*}{20} & $<1$ & $1,9 \times 10^{1}$ & \multirow[t]{2}{*}{20} & $<1$ & $1,4 \times 10^{1}$ \\
\hline & Colônias s/ halo & & 4,0 & $1,8 \times 10^{2}$ & & 3,0 & $1,4 \times 10^{2}$ \\
\hline \multirow{3}{*}{ 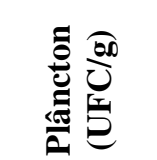 } & B. Quitinolíticas & \multirow{3}{*}{15} & $6,0 \times 10^{1}$ & $2,0 \times 10^{3}$ & \multirow{3}{*}{15} & $5,0 \times 10^{1}$ & $9,1 \times 10^{3}$ \\
\hline & & & & & & & \\
\hline & Colônias s/ halo & & $7,0 \times 10^{3}$ & $1,9 \times 10^{5}$ & & $2,0 \times 10^{3}$ & $2,6 \times 10^{5}$ \\
\hline
\end{tabular}

Legenda: m: valor mínimo M: valor máximo N: número de amostras coletadas
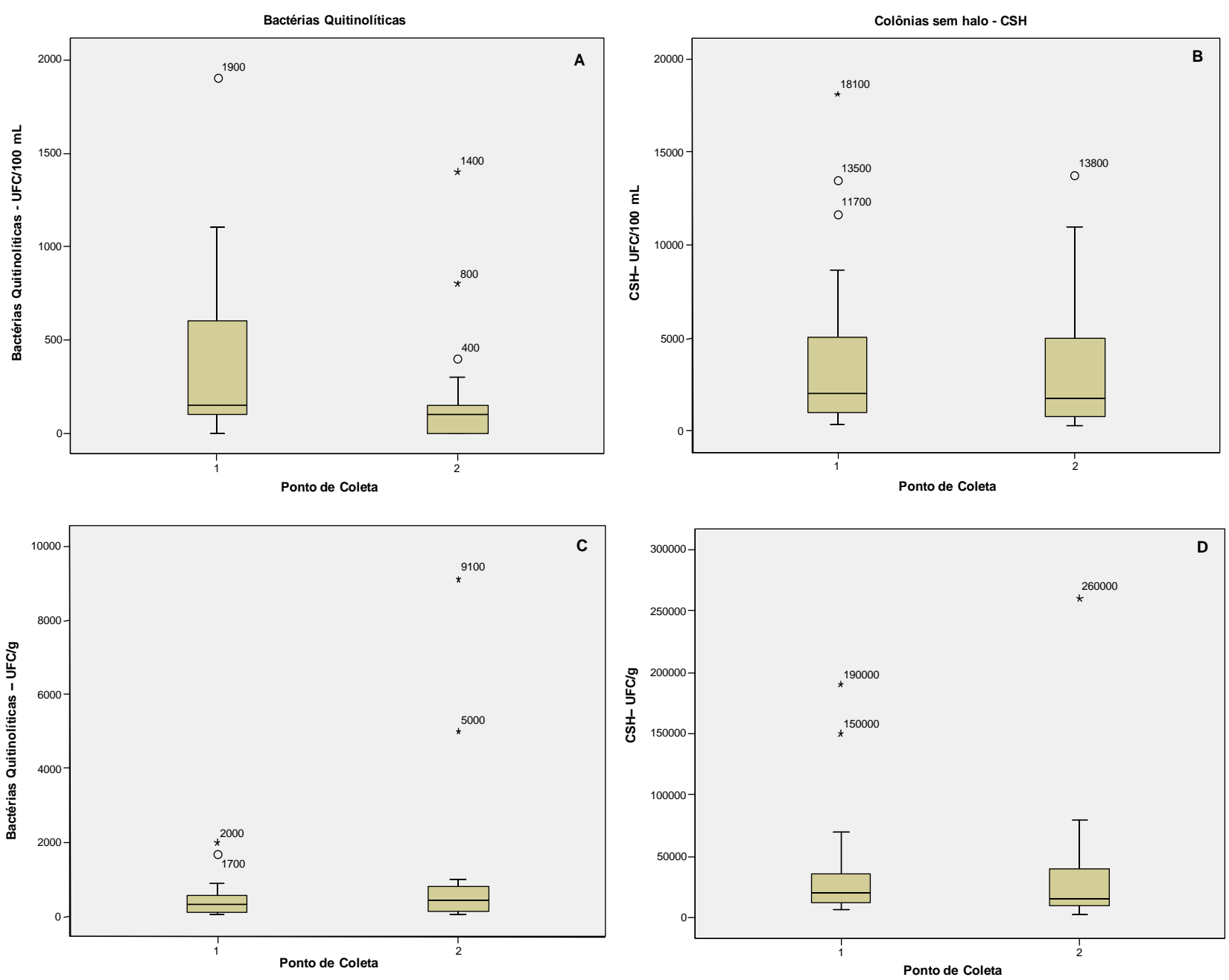

Figura 12 - Valor da mediana, percentil 25 e 75 das contagens de bactérias quitinolíticas e CSH nas amostras de água do mar (A e B) e plâncton (C e D) nos dois pontos de coleta do Canal de São Sebastião.

Nota: As contagens de bactérias em amostras de água estão em UFC/100 mL e nas amostras de plâncton estão em UFC/g.

Legenda:

\begin{tabular}{|l|l}
$\begin{array}{l}\text { Mediana } \\
\text { Percentil25 }\end{array}$ & valor Máximo \\
Valor mínimo
\end{tabular} 
Os dois pontos de coleta de amostras localizados no Canal de São Sebastião foram considerados estatisticamente semelhantes em relação às contagens de bactérias quitinolíticas, tanto para as amostras de água do mar $(\mathrm{p}=0,149)$, como para as amostras de plâncton $(\mathrm{p}=$ 0,663) de acordo com o Teste de Kruskal-Wallis. Também não foram encontradas diferenças significativas entre os dois pontos de coleta para as contagens de CSH em amostras de água do mar $(\mathrm{p}=0,598)$ e plâncton $(\mathrm{p}=0,520)$. Sendo assim, foi calculada a média aritmética das contagens de bactérias quitinolíticas e CSH nos dois pontos para mostrar a variação temporal dessas bactérias durante os vinte meses de coleta (Figura 13).

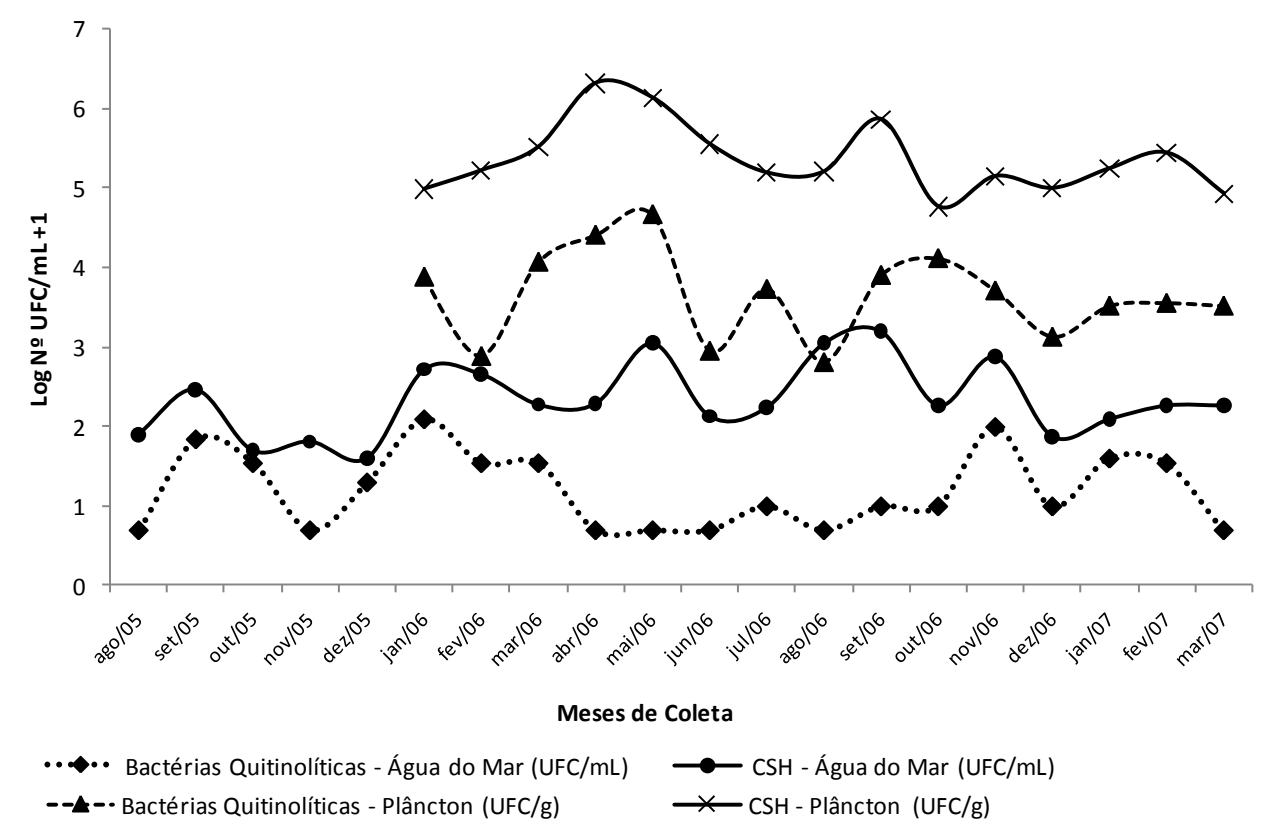

Figura 13 - Média aritmética das contagens de bactérias quitinolíticas e CSH em amostras de água do mar (UFC/mL) e plâncton (UFC/g) no Canal de São Sebastião.

\subsubsection{Ubatuba}

As bactérias quitinolíticas estiveram ausentes ( $<1$ UFC/mL ou g) em $33 \%$ e em $16 \%$ das amostras de água do mar e plâncton, respectivamente. No entanto, de forma geral, as contagens de bactérias quitinolíticas em amostras de água foram muito baixas, sendo que a maior contagem foi $2 \mathrm{UFC} / \mathrm{mL}$ no mês de março de 2006. Nas amostras de plâncton, as contagens de bactérias quitinolíticas apresentaram contagens mais elevadas, sendo que a maior contagem foi $2,8 \times 10^{3} \mathrm{UFC} / \mathrm{g}$, também no mês de março de 2006. 
Os valores mínimos e máximos das contagens de bactérias quitinolíticas e CSH nas amostras de água do mar e plâncton coletadas em Ubatuba podem ser visualizados na tabela 6. As contagens de bactérias quitinolíticas e CSH nos dois tipos de amostras também foram expressas em mediana e percentil 25 e 75 (Figura 14).

Tabela 6 - Valores mínimos e máximos de bactérias quitinolíticas e CSH em amostras de água do mar e plâncton coletadas em Ubatuba.

\begin{tabular}{|c|c|c|c|c|c|c|c|}
\hline \multirow{3}{*}{ Amostras } & \multicolumn{7}{|c|}{ Ubatuba } \\
\hline & \multirow{2}{*}{ Parâmetro } & \multicolumn{3}{|c|}{ Ponto 01 } & \multicolumn{3}{|c|}{ Ponto 02} \\
\hline & & $\mathrm{N}$ & $\mathrm{m}$ & M & $\mathrm{N}$ & $\mathrm{m}$ & M \\
\hline \multirow{2}{*}{ 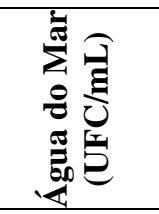 } & B. Quitinolíticas & \multirow[b]{2}{*}{06} & $<1$ & 1,0 & \multirow[b]{2}{*}{06} & $<1$ & 2,0 \\
\hline & Colônias s/ halo & & & $1,0 \times 10^{2}$ & & 5,0 & $6,0 \times 10^{1}$ \\
\hline \multirow{2}{*}{ 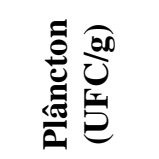 } & B. Quitinolíticas & \multirow{2}{*}{06} & $<1$ & $2,8 \times 10^{3}$ & \multirow{2}{*}{06} & $<1$ & $7,0 \times 10^{2}$ \\
\hline & & & $1,2 \times 10^{4}$ & $8,4 \times 10^{4}$ & & $2,9 \times 10^{3}$ & $6,4 \times 10^{4}$ \\
\hline
\end{tabular}

Legenda: m: valor mínimo M: valor máximo N: número de amostras coletadas. 

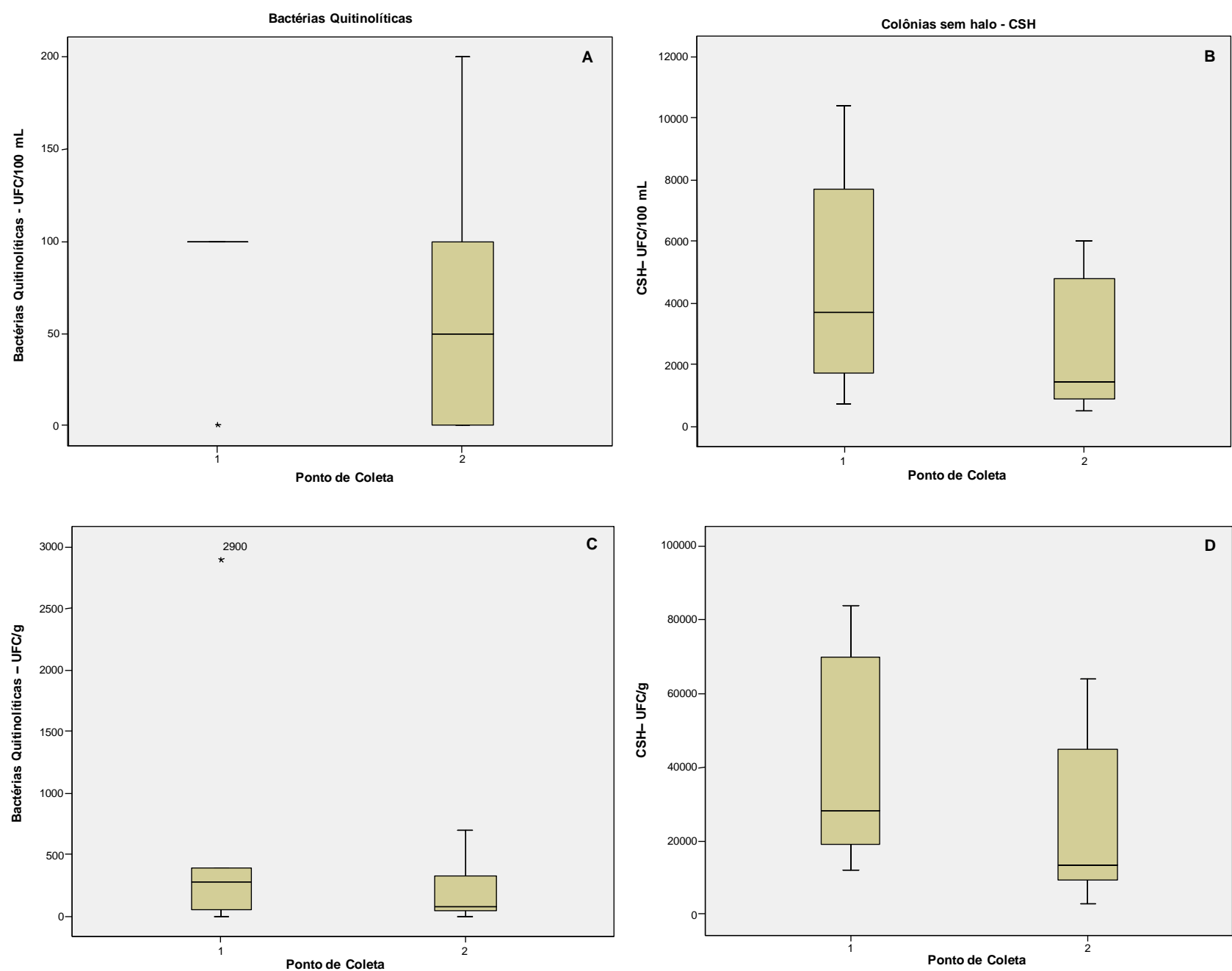

Figura 14 - Valor da mediana, percentil 25 e 75 das contagens de bactérias quitinolíticas e CSH nas amostras de água do mar (A e B) e plâncton (C e D) nos dois pontos de coleta de Ubatuba.

Nota: As contagens de bactérias em amostras de água estão em UFC/100 mL e nas amostras de plâncton estão em UFC/g

Legenda:

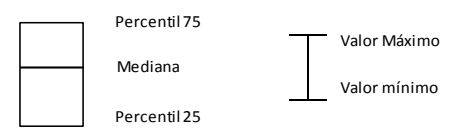

De acordo com o Teste de Kruskal-Wallis, os dois pontos de coleta de Ubatuba são estatisticamente semelhantes em relação às contagens de bactérias quitinolíticas em amostras de água do mar $(\mathrm{p}=0,523)$ e em amostras de plâncton $(\mathrm{p}=0,520)$. Pelas contagens de CSH também não foram encontradas diferenças estatisticamente significantes entre os dois pontos de coleta, tanto para as amostras de água do mar $(\mathrm{p}=0,262)$ como para as amostras de plâncton $(\mathrm{p}=0,173)$. Diante disso, foi calculada a média aritmética das contagens de bactérias quitinolíticas e CSH nos dois pontos para mostrar a variação temporal dessas bactérias durante os meses de coleta (Figura 15). 

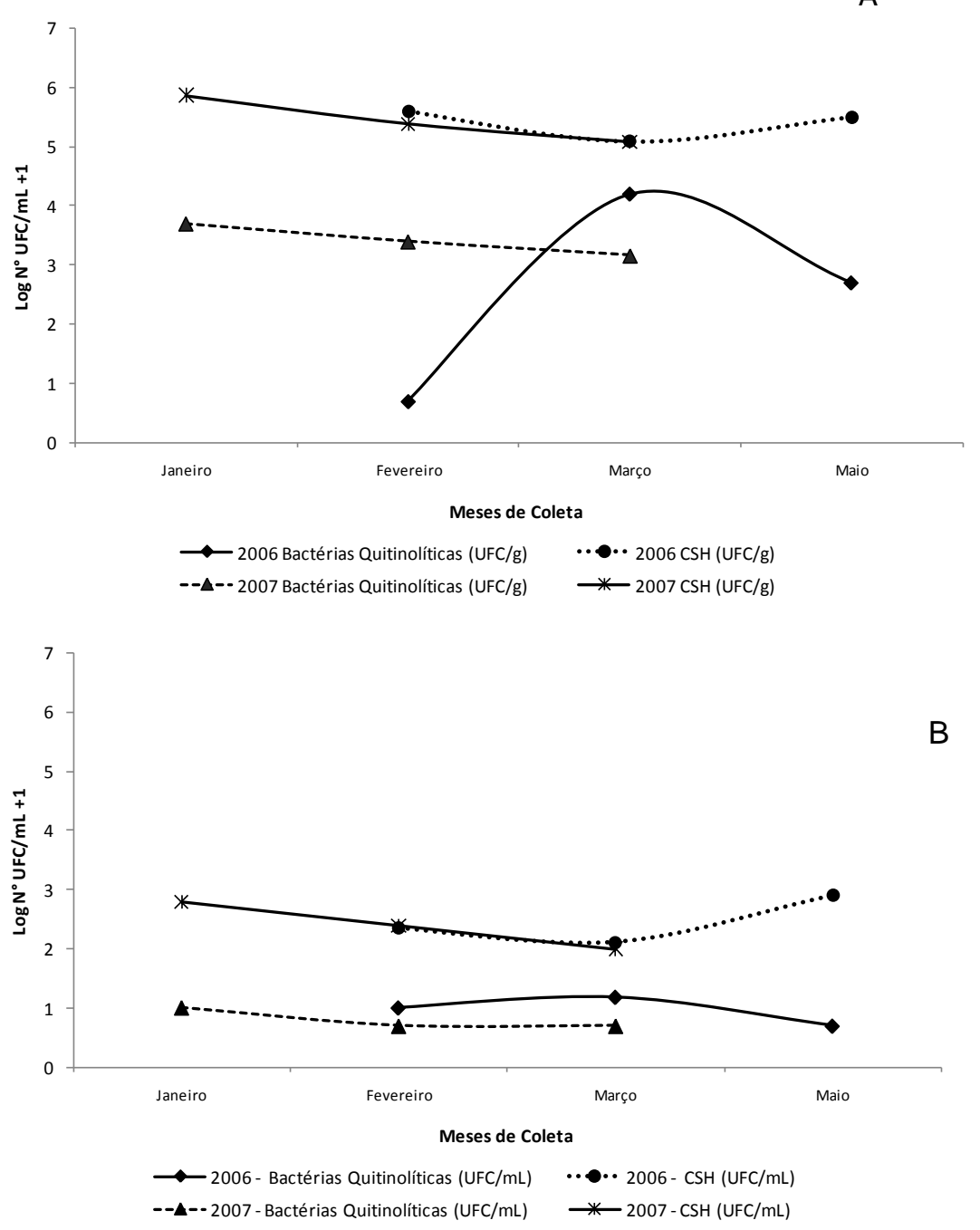

Figura 15 - Média aritmética das contagens de bactérias quitinolíticas e CSH em amostras de água do mar (A) e plâncton (B) de Ubatuba.

\subsubsection{Baixada Santista}

As bactérias quitinolíticas foram encontradas em 100\% das amostras de água do mar $(n=21)$ e plâncton $(n=20)$ coletadas na Baixada Santista, cujos valores mínimos e máximos das contagens de bactérias quitinolíticas e CSH podem ser observados na tabela 7. Os valores dessas contagens também estão expressos em mediana e percentil 25 e 75 (Figura 16). 
Tabela 7 - Valores mínimos e máximos de bactérias quitinolíticas e CSH em amostras de água do mar e plâncton da Baixada Santista.

\begin{tabular}{|c|c|c|c|c|c|c|c|c|c|c|}
\hline \multirow{3}{*}{ Amostras } & \multicolumn{10}{|c|}{ Baixada Santista } \\
\hline & \multirow{2}{*}{ Parâmetro } & \multicolumn{3}{|c|}{ Ponto 01} & \multicolumn{3}{|c|}{ Ponto 02} & \multicolumn{3}{|c|}{ Ponto 03} \\
\hline & & $\mathrm{N}$ & $\mathrm{m}$ & M & 1 & $\mathrm{~m}$ & M & $\mathrm{N}$ & $\mathrm{m}$ & M \\
\hline \multirow{2}{*}{ 恶离 } & BQ & \multirow{2}{*}{7} & $8,0 \times 10^{0}$ & $1,4 \times 10^{2}$ & \multirow{2}{*}{7} & $4,0 \times 10^{0}$ & $1,4 \times 10^{1}$ & \multirow{2}{*}{7} & $1,6 \times 10^{1}$ & $2,2 \times 10^{2}$ \\
\hline & $\mathrm{CSH}$ & & $3,7 \times 10^{1}$ & $6,9 \times 10^{2}$ & & $2,6 \times 10^{1}$ & $4,2 \times 10^{2}$ & & $2,9 \times 10^{1}$ & $5,2 \times 10^{2}$ \\
\hline \multirow{2}{*}{ 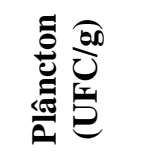 } & BQ & \multirow{2}{*}{7} & $4,9 \times 10^{2}$ & $3,6 \times 10^{4}$ & \multirow{2}{*}{7} & $2,0 \times 10^{2}$ & $7,0 \times 10^{2}$ & \multirow{2}{*}{6} & $1,9 \times 10^{3}$ & $4,4 \times 10^{4}$ \\
\hline & $\mathrm{CSH}$ & & $5,3 \times 10^{3}$ & $5,8 \times 10^{5}$ & & $1,3 \times 10^{3}$ & $6,5 \times 10^{5}$ & & $6,0 \times 10^{3}$ & $9,1 \times 10^{5}$ \\
\hline
\end{tabular}

Legenda: BQ: bactérias quitinolíticas; CSH: colônias sem halo; m: valor mínimo; M: valor máximo; N: número de amostra coletada

Os pontos de coleta de amostras 1 e 3 não apresentaram diferenças estatisticamente significantes (Teste de Kruskal-Wallis) entre as contagens de bactérias quitinolíticas em amostras de água do mar $(\mathrm{p}=0,442)$. No entanto, o Ponto 2 foi considerado estatisticamente diferente do Ponto $1(\mathrm{p}=0,025)$ e do Ponto $3(\mathrm{p}=0,002)$ também em relação às contagens de bactérias quitinolíticas. Em relação às contagens de CSH em amostras de água do mar, os três pontos foram considerados iguais $(\mathrm{p}=0,615)$. As contagens de bactérias quitinolíticas e CSH em amostras de água do mar em cada mês de coleta podem ser observadas na figura 17.

Nas amostras de plâncton, também não foram encontradas diferenças estatisticamente significantes entre os três pontos de coleta, de acordo com as contagens de bactérias quitinolíticas $(\mathrm{p}=0,122)$ e CSH $(\mathrm{p}=0,793)$. Sendo assim, foi calculada a média aritmética das contagens de bactérias quitinolíticas e CSH nos dois pontos de coleta para mostrar a variação temporal dessas bactérias durante os meses de amostragem (Figura 18). 

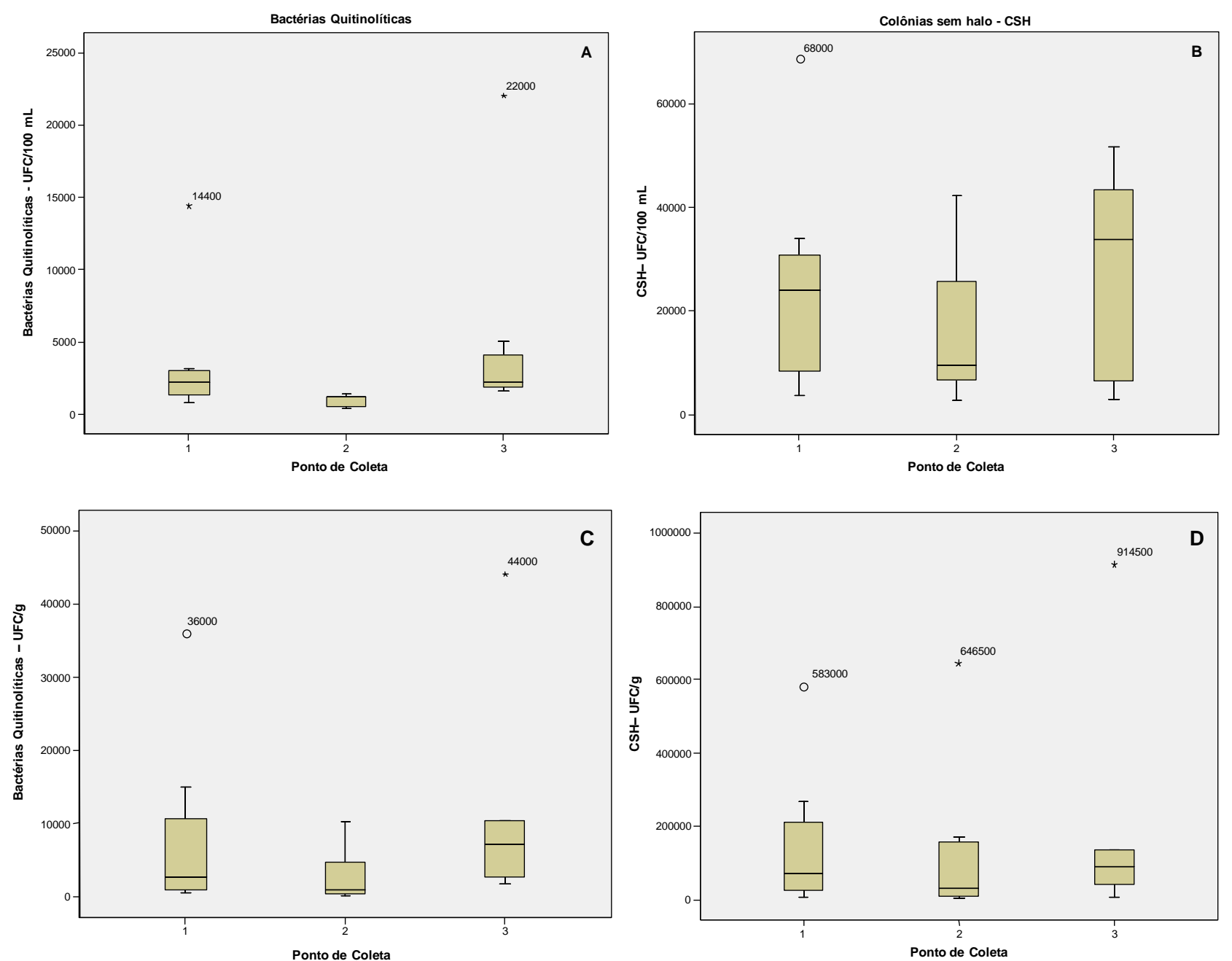

Figura 16 - Valor da mediana, percentil 25 e 75 das contagens de bactérias quitinolíticas e CSH nas amostras de água do mar (A e B) e plâncton (C e D) nos três pontos de coleta da Baixada Santista.

Nota: As contagens de bactérias em amostras de água estão em UFC/100 mL e nas amostras de plâncton estão em UFC/g.

Legenda:

$\square \begin{array}{ll}\begin{array}{l}\text { Mercentil75 } \\ \text { Mediana } \\ \text { Percentil25 }\end{array} & \text { Valor Máximo } \\ & \text { Valor mínimo }\end{array}$ 

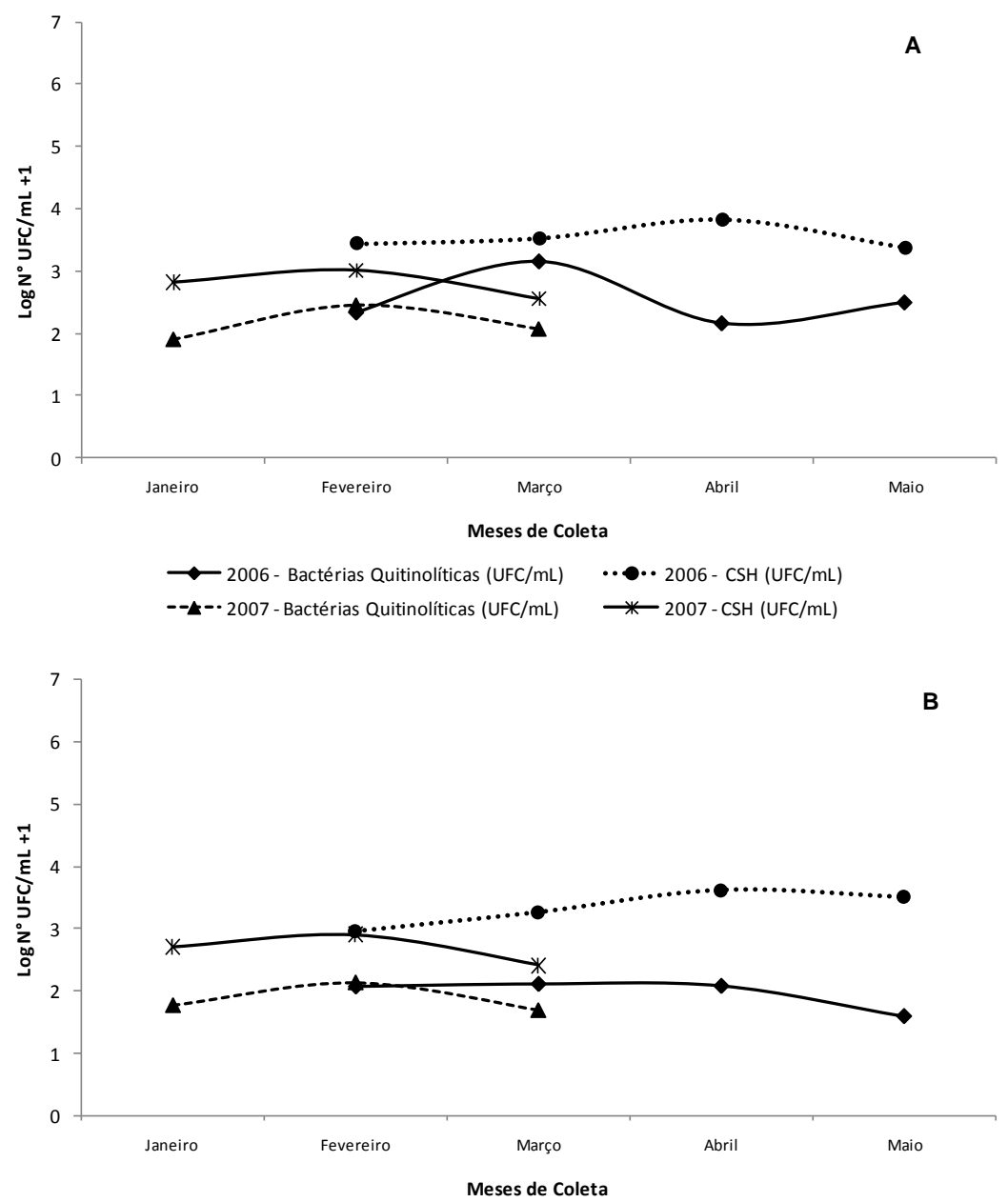

$\longrightarrow 2006$ - Bactérias Quitinolíticas (UFC/mL) $\quad \cdots \bullet \cdot 2006$ - CSH (UFC/mL)

--A-- 2007 - Bactérias Quitinolíticas (UFC/mL) $\rightarrow 2007$ - CSH (UFC/mL)

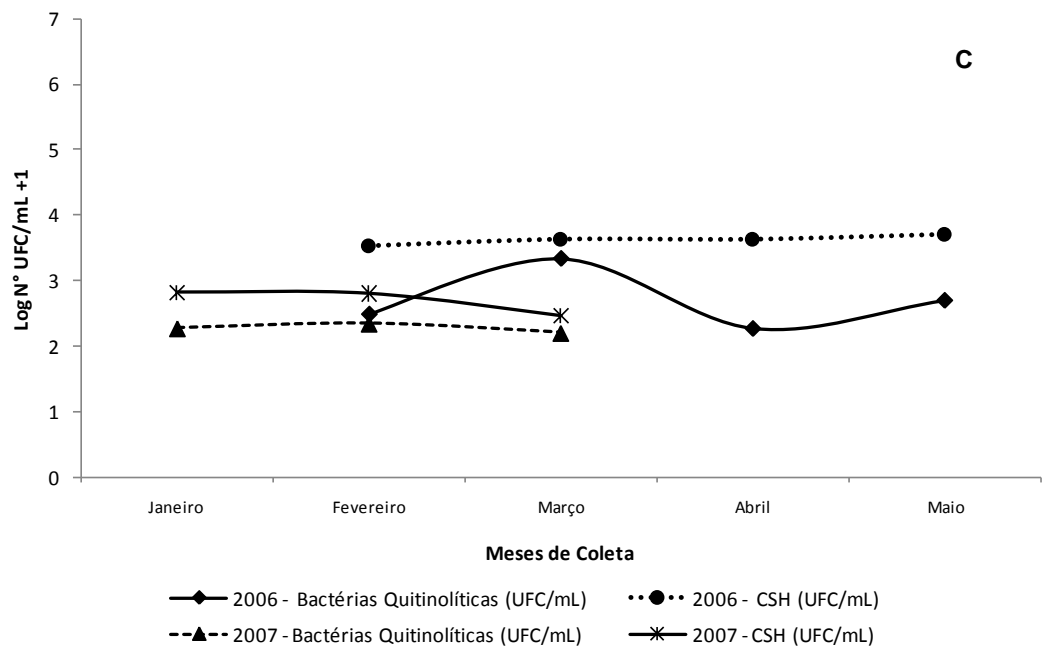

Figura 17 - Contagens de bactérias quitinolíticas e CSH em amostras de água do mar coletadas na Baixada Santista.

Legenda - A: Ponto 1; B: ponto 2; C: ponto 3; BQ: Bactérias quitinolíticas; CSH: Colônias sem halo 


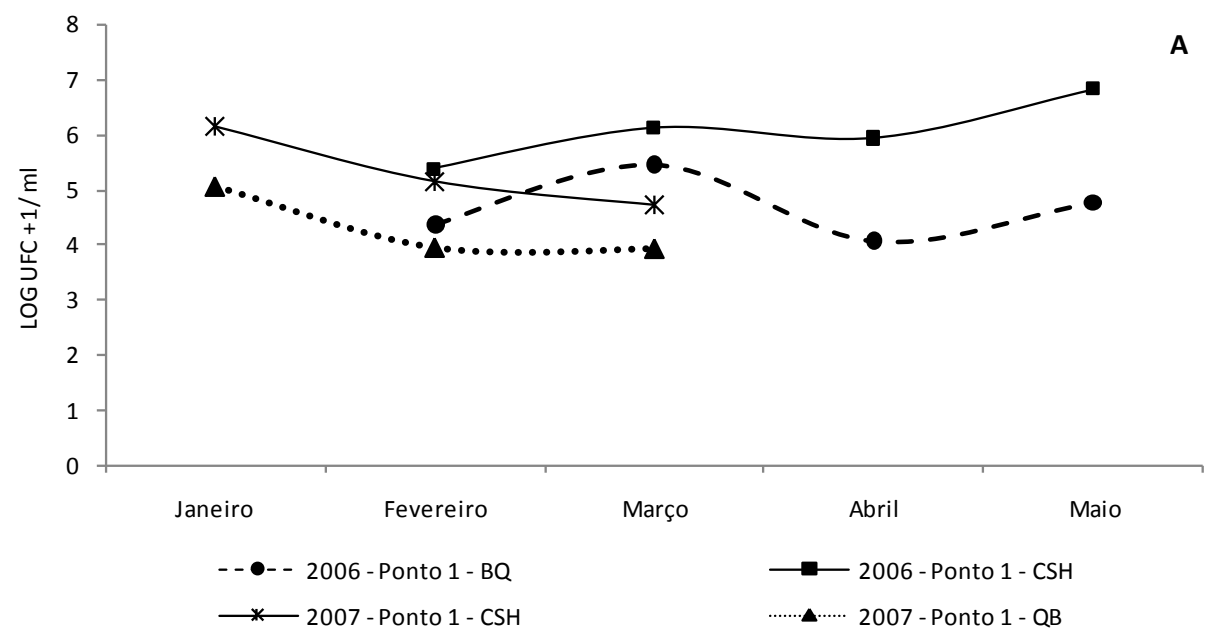

Figura 18 - Média aritmética das contagens de bactérias quitinolíticas e CSH em amostras de plâncton coletadas na Baixada Santista.

Legenda - BQ: Bactérias quitinolíticas; CSH: Colônias sem halo

\subsubsection{Comparação entre as contagens de bactérias quitinolíticas, parâmetros físico- químicos e indicadores de contaminação fecal}

As maiores contagens de bactérias quitinolíticas em amostras de água do mar foram encontradas na Baixada Santista, enquanto que as menores contagens foram observadas em Ubatuba. Diferenças estatisticamente significantes foram observadas entre as contagens de bactérias quitinolíticas presentes nas amostras do Canal de São Sebastião e Baixada Santista $(\mathrm{p}=0,000)$ e entre as contagens obtidas em amostras da Baixada Santista e Ubatuba $(\mathrm{p}=$ 0,000). Entre as contagens de bactérias quitinolíticas obtidas de amostras de água do mar do Canal de São Sebastião e Ubatuba não foram encontradas diferenças estatisticamente significantes $(\mathrm{p}=0,105)$. Em relação às contagens de CSH em amostras de água do mar, os três ambientes foram considerados estatisticamente diferentes.

Em amostras de plâncton, as maiores contagens de bactérias quitinolíticas também foram encontradas em amostras coletadas na Baixada Santista. De acordo com as análises estatísticas, os três ambientes estudados são estatisticamente diferentes em relação às contagens de bactérias quitinolíticas, visto que o índice de significância (p) encontrado entre as contagens bacterianas presentes nas amostras do Canal de São Sebastião e Baixada Santista, Canal de São Sebastião e Ubatuba e Ubatuba e Baixada Santista foi, 
respectivamente, 0,000, 0,050 e 0,000. Em contrapartida, de acordo com as contagens de CSH em amostras de plâncton, os três ambientes foram considerados estatisticamente semelhantes.

Foi verificada correlação positiva entre a contagem de bactérias quitinolíticas e coliformes termotolerantes em amostras de água do mar do Canal de Sebastião $(p=0,002$ e $r=0,468)$ e da Baixada Santista ( $p=0,000$ e $r=0,796$ ). E, somente na Baixada Santista foram encontradas correlações entre as contagens de bactérias quitinolíticas e Escherichia coli $(\mathrm{p}=0,007$ e $\mathrm{r}=0,567)$ e entre bactérias quitinolíticas e CSH ( $\mathrm{p}=0,028$ e $\mathrm{r}=0,479)$. Somente, em amostras de plâncton coletadas na Baixada Santista foi observada correlação entre as contagens de bactérias quitinolíticas e CSH (p=0,005 e r=0,598).

Foram realizadas análises de correlação (Pearson Correlation) entre as contagens de bactérias quitinolíticas e os quatro parâmetros físico-químicos analisados (temperatura, pH, salinidade e condutividade). No entanto, somente foi encontrada correlação entre as contagens de bactérias quitinolíticas e $\mathrm{pH}(\mathrm{p}=0,032$ e $\mathrm{r}=-0,470)$ e apenas nas amostras coletadas na Baixada Santista.

As contagens de bactérias quitinolíticas encontradas em amostras de água do mar do Canal de São Sebastião foram comparadas em relação à corrente marítima, direção do vento e condição do tempo (céu nublado ou ensolarado) presentes no dia da coleta de amostras no Canal de São Sebastião. De acordo com as análises estatísticas, foi verificado que o número de bactérias quitinolíticas aumentou na presença de corrente marítima sul $(p=0,009)$, vento em direção sul $(p=0,015)$ e em dias de céu nublado $(p=0,007)$. Essas análises não foram realizadas com os outros dois locais de coleta, visto que esses dados climáticos não foram obtidos.

\subsection{CARACTERIZAÇÃO FENÓTIPICA DAS BACTÉRIAS QUITINOLÍTICAS}

\subsubsection{Reisolamento e determinação do tempo de incubação para formação de halo de hidrólise de quitina}

Foram isoladas 492 bactérias quitinolíticas em amostras coletadas na Baixada Santista $(n=242)$, no Canal de São Sebastião $(n=199)$ e em Ubatuba $(n=51)$. Essas bactérias foram reisoladas em MMQ1, incubadas a $27 \pm 2{ }^{\circ} \mathrm{C}$ e observadas diariamente até o surgimento do halo de hidrólise de quitina. Todos os isolados foram submetidos à coloração de Gram e ainda 
foi realizado o teste com $\mathrm{KOH}$ para confirmar o número de gram-negativos e gram-positivos obtidos (Figura 19).

O maior número de bactérias quitinolíticas em amostras de água do mar foi obtido na Baixada Santista, correspondendo a 59\% do total de bactérias isoladas. Em amostras de plâncton, o maior número de bactérias quitinolíticas foi obtido no Canal de Sebastião (44\%), mas é importante lembrar que o número de coleta de amostras nesse local também foi maior.
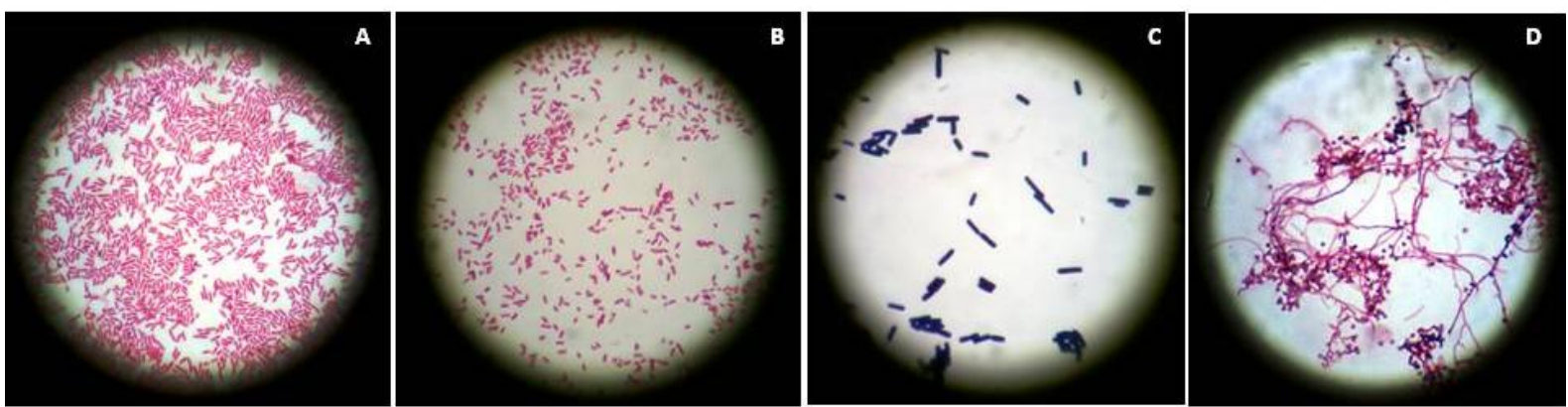

Figura 19 - Coloração de Gram de bactérias quitinolíticas - A e B: gram-negativos; C: grampositivo; D: gram-positivo filamentoso.

A figura 20 apresenta a frequência de bactérias quitinolíticas gram-negativas, grampositivos (bacilos/cocos) e gram-positivos filamentosos em cada local estudado e por tipo de amostra (água e plâncton). Para facilitar a visualização, o percentual de gram-positivos filamentosos foi apresentado separadamente dos demais gram-positivos. A maior frequência de bactérias quitinolíticas gram-negativas foi encontrada na Baixada Santista, tanto em amostras de água do mar (73\%) como de plâncton (83\%). Em amostras de água do mar de Ubatuba foi encontrada a maior frequência de bactérias quitinolíticas gram-positivas filamentosas $(90 \%)$. Porém, o número total de bactérias quitinolíticas obtidas em amostras de água de Ubatuba foi o menor $(n=10)$ em comparação com o Canal de São Sebastião $(n=84)$ e a Baixada Santista $(n=135)$. 


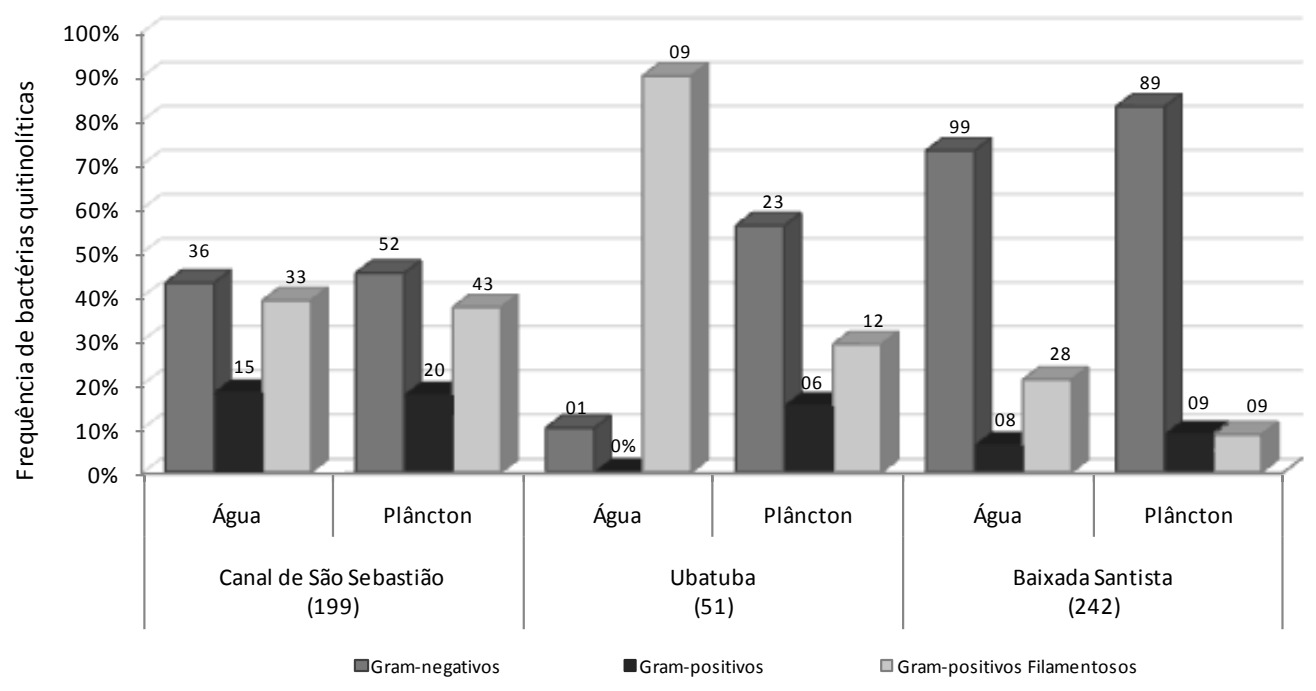

Figura 20 - Freqüência de bactérias quitinolíticas gram-negativas, gram-positivas (bacilos e cocos) e grampositivos filamentosos.

Nota: Os valores acima das barras correspondem ao número de bactérias quitinolíticas isoladas.

Ao analisarmos os resultados por tipo de amostra, sem diferenciar o local de coleta, verificamos que em 56 amostras de água e em 58 amostras de plâncton, onde foram obtidas bactérias quitinolíticas viáveis, $68 \%$ e $59 \%$ dessas amostras, respectivamente, apresentaram bactérias quitinolíticas gram-positivas filamentosas e o percentual de bactérias gram-negativas nessas amostras de água foi de $57 \%$ e em amostras de plâncton foi de $79 \%$. Em $32 \%$ das amostras de água foram encontradas somente bactérias quitinolíticas gram-positivas filamentosas, enquanto que o percentual de amostras de plâncton que apresentaram apenas bactérias quitinolíticas gram-positivas filamentosas foi de $12 \%$.

Em amostras de água do mar e plâncton, coletadas no Canal de São Sebastião, onde o período de amostragem foi maior, verificamos que bactérias quitinolíticas gram-negativas estavam presentes em $42,8 \%$ das amostras de água, enquanto que bactérias quitinolíticas gram-positivas filamentosas foram encontradas em $68 \%$ das amostras e bactérias quitinolíticas gram-positivas (cocos e bacilos) estavam presentes em $25 \%$ dessas amostras. Em relação às amostras de plâncton do Canal de São Sebastião, bactérias quitinolíticas gramnegativas estavam presentes em $75 \%$ das amostras e em $42 \%$ e $75 \%$ das amostras foram encontradas bactérias quitinolíticas gram-positivas (cocos/bacilos) e gram-positivas filamentosas, respectivamente.

Foi verificado, após monitorar diariamente, o crescimento de todas as bactérias quitinolíticas e a formação do halo de hidrólise em placas contendo MMQ1, que 96\% dos 
isolados gram-negativos e gram-positivos, exceto os gram-positivos filamentosos, apresentavam halo de hidrólise de quitina dentro de 48 e 96 horas e 100\% dos gram-positivos filamentosos apresentam o halo de hidrólise no período de 72 a 168 horas de incubação. Diante desses resultados, foi estabelecido que o tempo ótimo de incubação para realizar a medida dos halos de hidrólise de quitina em MMQ1 era de 96 horas para as bactérias gramnegativas e gram-positivas (bacilo/cocos) e de 168 horas de incubação para os gram-positivos filamentosos.

\subsubsection{Avaliação da degradação de quitina em meio sólido}

Todas as bactérias quitinolíticas foram semeadas em MMQ1 e incubadas a $27 \pm 2{ }^{\circ} \mathrm{C}$ por 96 a 168 horas. A medida do halo das bactérias gram-negativas e gram-positivas, exceto gram-positivas filamentosas, foi realizada com 96 horas de incubação e das bactérias quitinolíticas gram-positivas filamentosas foi realizada com 168 horas de incubação (Tabela 8). O diâmetro do halo de hidrólise de quitina das cepas padrão utilizadas como controles positivos nos ensaios de degradação de quitina em MMQ1 também foi medido com 96 horas de incubação e os resultados podem ser visualizados na tabela 9.

Tabela 8 - Valores mínimos e máximos do halo de hidrólise de quitina das bactérias quitinolíticas isoladas na Baixada Santista, Canal de São Sebastião e Ubatuba.

\begin{tabular}{|c|c|c|c|c|c|c|c|c|c|c|}
\hline \multirow{3}{*}{$\frac{\mathscr{E}}{\tilde{E}}$} & \multicolumn{10}{|c|}{ Local de Coleta } \\
\hline & \multirow[b]{2}{*}{ Parâmetro } & \multicolumn{3}{|c|}{ Baixada Santista } & \multicolumn{3}{|c|}{ Canal de São Sebastião } & \multicolumn{3}{|c|}{ Ubatuba } \\
\hline & & $\mathrm{n}$ & $\begin{array}{c}\mathrm{m} \\
(\mathrm{mm})\end{array}$ & $\begin{array}{c}\mathrm{M} \\
(\mathrm{mm})\end{array}$ & $\mathrm{n}$ & $\begin{array}{c}\mathrm{m} \\
(\mathrm{mm})\end{array}$ & $\begin{array}{c}\mathrm{M} \\
(\mathrm{mm})\end{array}$ & $\mathrm{n}$ & $\begin{array}{c}\mathrm{m} \\
(\mathrm{mm})\end{array}$ & $\begin{array}{c}\mathrm{M} \\
(\mathrm{mm}) \\
\end{array}$ \\
\hline \multirow{3}{*}{ 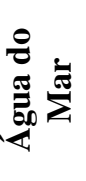 } & Gram-negativo & 99 & 0,77 & 6,91 & 36 & 0,41 & 5,36 & 01 & \multicolumn{2}{|c|}{1,79} \\
\hline & Gram-positivo $^{1}$ & 08 & 0,80 & 6,72 & 15 & 0,71 & 4,83 & 0 & - & - \\
\hline & G.P. Filamentoso ${ }^{2}$ & 28 & 0,86 & 6,84 & 33 & 1,60 & 8,84 & 09 & 1,31 & 5,25 \\
\hline \multirow{4}{*}{ 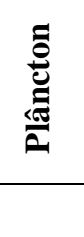 } & Gram-negativo & 89 & 1,11 & 5,89 & 52 & 0,54 & 6,49 & 23 & 0,90 & 5,24 \\
\hline & Gram-positivo $^{1}$ & 09 & 1,30 & 3,89 & 20 & 0,56 & 4,68 & 06 & 1,06 & 2,88 \\
\hline & G.P. Filamentoso ${ }^{2}$ & 09 & 1,97 & 7,01 & 43 & 0,88 & 8,41 & 12 & 1,14 & 6,91 \\
\hline & Total de isolados & \multicolumn{3}{|c|}{242} & \multicolumn{3}{|c|}{199} & \multicolumn{3}{|c|}{51} \\
\hline
\end{tabular}

Legenda: n: número de bactérias quitinolíticas isoladas; m: valor mínimo; M: valor máximo; mm: milímetros; G.P.: gram-positivo; ${ }^{1}$ : bacilos e cocos gram-positivos; ${ }^{2}$ : gram-positivos filamentosos. 
Tabela 9 - Diâmetro do halo de hidrólise de quitina produzidos por cepas padrão em MMQ1.

\begin{tabular}{lcc}
\hline \multicolumn{1}{c}{ Espécie } & Cepa n $^{\mathbf{0}}$ & Diâmetro do Halo (mm) \\
\hline Vibrio mimicus & RC55 & 1,90 \\
Vibrio mimicus & RC57 & 1,88 \\
Vibrio cholerae Não-O1 & RC60 & 1,38 \\
Vibrio cholerae Não-O1 & RC70 & 1,29 \\
Vibrio fluvialis & ATCC 33809 & 1,41 \\
Vibrio proteolyticus & ATCC 15338 & 1,62 \\
Vibrio splendidus & ATCC 33125 & 1,77 \\
\hline
\end{tabular}

Considerando o diâmetro do halo formado pelas bactérias quitinolíticas com 96 horas de incubação, verificamos que $63 \%$ e $72 \%$ das bactérias isoladas de amostras de água e plâncton, respectivamente, do Canal de São Sebastião apresentaram halos de hidrólise com medidas variando de 1,1 a 3,0 mm de diâmetro, enquanto que na Baixada Santista, apenas $36 \%$ das bactérias isoladas de amostras de água e $47 \%$ das bactérias isoladas de amostras de plâncton apresentaram medidas de halo variando de 1,1 a 3,0 mm de diâmetro (Figuras 21A e 21C). Em amostras de água do mar e plâncton coletadas na Baixada Santista, 55\% e 53\% das bactérias quitinolíticas, respectivamente, apresentaram halos com diâmetro variando de 3,1 a 6,0 mm (Figura 21C). Em contrapartida, no Canal de São Sebastião, a porcentagem de bactérias quitinolíticas com halo de hidrólise de 3,1 a 6,0 mm de diâmetro foi de $23 \%$ em amostras de água do mar e 12,5\% em amostras de plâncton (Figura 21A).

A maior porcentagem $(51 \%)$ de bactérias quitinolíticas gram-negativas e grampositivas (bacilos/cocos) isoladas de amostras de plâncton coletadas em Ubatuba apresentaram halo variando de 1,1 a 3,0 mm de diâmetro e as bactérias quitinolíticas que apresentaram halos com diâmetros de 3,1 a 6,0 mm corresponderam a 34\%. Em amostras de água do mar foi isolada apenas uma bactéria quitinolítica gram-negativa a qual apresentou halo com diâmetro de 1,79 mm (Figura 21B).

Em relação às bactérias quitinolíticas gram-positivas filamentosas, verificamos que em amostras provenientes do Canal de São Sebastião, a maior porcentagem de bactérias que apresentaram halos de hidrólise de quitina com diâmetro de 3,1 a 6,0 mm, foi obtida de 
amostras de água do mar (61\%), enquanto que em plâncton a porcentagem foi de $40 \%$. A porcentagem das bactérias que apresentaram halos com diâmetros variando de 1,1 a 3,0 mm em amostras de água do mar e plâncton do Canal de São Sebastião foi de $33 \%$ e $49 \%$, respectivamente (Figura 21A). Em amostras da Baixada Santista, a maior porcentagem de bactérias quitinolíticas apresentou halos variando de 3,1 a 6,0 mm de diâmetro, tanto em amostras de água do mar (60\%) como em amostras de plâncton (55\%). Entretanto, foi verificado que $21 \%$ e $33 \%$ das bactérias quitinolíticas isoladas de amostras de água do mar e plâncton, respectivamente, apresentaram halo com diâmetros de 1,1 a 3,0 mm (Figura 21C). Nas amostras de água do mar coletadas em Ubatuba, 45\% dos isolados apresentaram halo de hidrólise de quitina com diâmetro de 1,1 a 3,0 mm e 55\% com diâmetro de 3,1 a 6,0 mm. Em amostras de plâncton, a maior porcentagem de bactérias (58\%) apresentou halo variando de 1,1 a 3,0 mm de diâmetro em comparação com a porcentagem de isolados (33\%) que apresentaram halo com diâmetro de 3,1 a 6,0 mm (Figura 21B). 

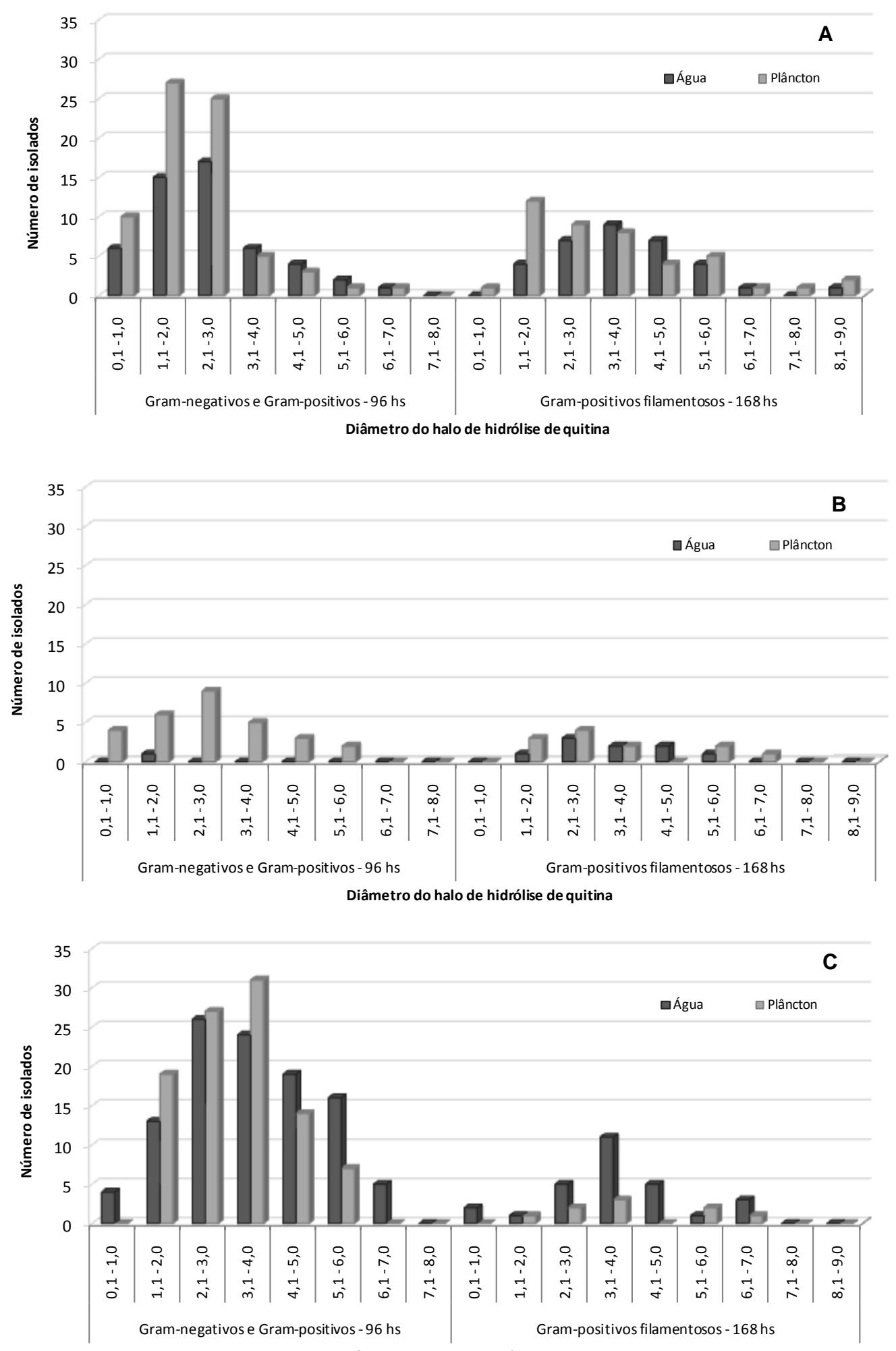

Diâmetro do halo de hidrólise de quitina

Figura 21 - Distribuição de bactérias quitinolíticas isoladas de amostras de água do mar e plâncton do Canal de São Sebastião (A), Ubatuba (B) e Baixada Santista (C), de acordo com o diâmetro do halo de hidrólise de quitina e tipo de bactéria.

Nota - diâmetro: milímetros. 
O diâmetro do halo de hidrólise de quitina produzido pelas bactérias quitinolíticas gram-negativas e gram-positivas (bacilos e cocos) (96 horas de incubação) e pelas bactérias quitinolíticas gram-positivas filamentosas (168 horas de incubação), isoladas de amostras de água do mar e plâncton provenientes de cada local de coleta, também foi expresso em mediana e percentil 25 e 75 (Figura 22).
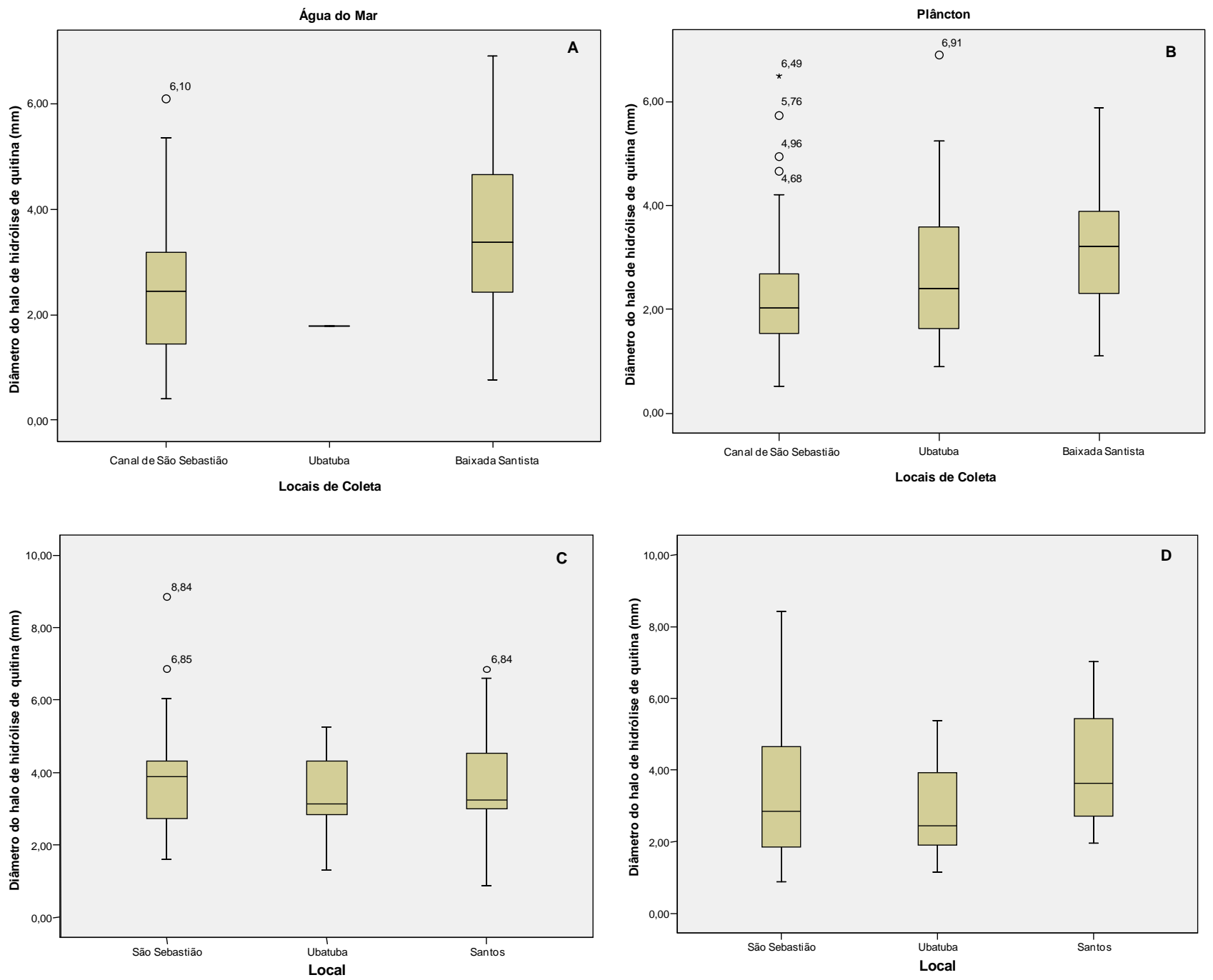

Figura 22 - Valor da mediana, percentil 25 e 75 do diâmetro do halo de hidrólise de quitina produzido pelas bactérias quitinolíticas gram-negativas e gram-positivas (bacilos e cocos) após 96 horas de incubação (A e B) e pelas bactérias quitinolíticas filamentosas após 168 horas de incubação (C e D) isoladas em amostras do Canal de São Sebastião, Ubatuba e Baixada Santista.

A e C: Amostras de água do mar; B e D: amostras de plâncton

Legenda:

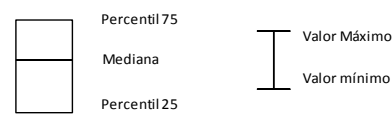


Foram verificadas diferenças estatisticamente significantes (Teste de Kruskal-Wallis) ao comparar os valores do diâmetro do halo produzidos pelas bactérias quitinolíticas gramnegativas e gram-positivas (bacilos e cocos) isoladas de amostras de água do mar do Canal de São Sebastião e Baixada Santista $(\mathrm{p}=0,000)$ após 96 horas de incubação. Entretanto, essa comparação não pôde ser realizada com as bactérias quitinolíticas isoladas de amostras de água do mar coletadas em Ubatuba devido ao número insuficiente de isolados. Em amostras de plâncton, foram encontradas diferenças estatisticamente significantes somente entre o diâmetro do halo de hidrólise de quitina produzidos pelas bactérias quitinolíticas isoladas do Canal de São Sebastião e Baixada Santista $(\mathrm{p}=0,000)$ e entre Ubatuba e Baixada Santista (p= $0,049)$.

Analisando o diâmetro do halo de hidrólise de quitina produzido pelas bactérias quitinolíticas em relação ao ponto de amostragem de cada local estudado, verificamos diferenças estatisticamente significantes somente em amostras de água do mar coletadas na Baixada Santista e entre os pontos 1 e $2(p=0,046)$ e os pontos 2 e $3(p=0,003)$.

Em relação às bactérias gram-positivas filamentosas, não foram observadas diferenças estatisticamente significantes entre os valores do diâmetro do halo de hidrólise de quitina ao comparar os resultados por local de coleta ou por ponto de amostragem em cada ecossistema marinho estudado.

\subsubsection{Quantificação de atividade enzimática através da liberação de $N$-acetil-glicosamina (GIcNAc)}

Todas as bactérias quitinolíticas $(n=492)$ foram submetidas à quantificação de enzimas totais necessárias à liberação de $N$-acetil-glicosamina a partir da degradação de quitina coloidal em caldo MMQ1, sendo que as bactérias quitinolíticas isoladas de amostras de água do mar e de plâncton apresentaram atividade enzimática variando de 0,00 a 8,81 U . $\mathrm{mL}^{-1}$ e 0,00 a $7,80 \mathrm{U} . \mathrm{mL}^{-1}$ de enzimas, respectivamente.

As bactérias quitinolíticas gram-negativas e gram-positivas (bacilos/cocos) isoladas de amostras de água do mar coletadas no Canal de São Sebastião apresentaram valores de produção enzimática variando de 0,00 a 7,34 U . $\mathrm{mL}^{-1}$ (Figura 23A). Foi verificado que 75\% dessas bactérias não apresentaram atividade enzimática e $22 \%$ apresentaram valores variando de 0,01 a 4,99 $\mathrm{U} . \mathrm{mL}^{-1}$. Nessas amostras, apenas dois isolados (4\%), ambos gram-negativos, apresentaram mais de 7,0 $\mathrm{U} \cdot \mathrm{mL}^{-1}$ de enzima $\left(\mathrm{CH} 20-7,34 \mathrm{U} \cdot \mathrm{mL}^{-1} ; \mathrm{CH} 101\right.$ - 
7,29 U . mL ${ }^{-1}$ ), sendo que a bactéria CH20 foi isolada no Ponto 2 em 19/09/2005 e a CH101 foi isolada no Ponto 1 em 13/02/2006

Em amostras de plâncton coletadas no Canal de São Sebastião, a porcentagem de bactérias quitinolíticas gram-negativas e gram-positivas (bacilos/cocos) que não apresentou atividade enzimática foi de $83 \%$ e que apresentou produção enzimática variando de 0,01 a $4,99 \mathrm{U} \cdot \mathrm{mL}^{-1}$ foi de $14 \%$ (Figura 23A). As bactérias que apresentaram maiores valores enzimáticos foram isoladas em 18/07/2006: uma no Ponto $1\left(\mathrm{CHZ113}-7,90 \mathrm{U} \cdot \mathrm{mL}^{-1}\right)$ e outra no Ponto $2\left(\mathrm{CHZ109}_{\mathrm{T}}-6,80 \mathrm{U} \cdot \mathrm{mL}^{-1}\right)$ e as duas foram classificadas como gramnegativas.

A bactéria CH178, único isolado gram-negativo obtido em amostras de água do mar de Ubatuba, não apresentou atividade enzimática $\left(0,0 \mathrm{U} \cdot \mathrm{mL}^{-1}\right)$. E, 93\% do total de bactérias gram-negativas e gram-positivas (bacilos/cocos), isolados de amostras de plâncton, também não apresentaram produção enzimática. Nessas amostras, somente duas bactérias (7\%), ambas gram-negativas, isoladas no Ponto 2 em 23/01/2007, produziram mais de 0,5 $\mathrm{U}^{-\mathrm{mL}^{-1}}$ de enzima (CHZ181 - 0,52 U . mL $L^{-1}$; CHZ183 - 1,38 U . mL ${ }^{-1}$ ) (Figura 23B).

A maior atividade enzimática foi obtida por bactérias quitinolíticas isoladas de amostras de água da Baixada Santista, cujos valores variaram de 0,00 a $8,81 \mathrm{U} \cdot \mathrm{mL}^{-1}$ de enzimas. A porcentagem de bactérias quitinolíticas isoladas de amostras de água que não apresentou atividade enzimática foi de $40 \%$. E, $44 \%$ e $15 \%$ do total de gram-negativas e gram-positivas (bacilos/cocos), produziram de 0,01 a 4,99, e 5,0 a 8,81 U . $\mathrm{mL}^{-1}$ de enzimas, respectivamente (Figura 23C). Foram obtidas 11 bactérias quitinolíticas gram-negativas que produziram mais de 7,0 $\mathrm{U} . \mathrm{mL}^{-1}$ de enzimas, das quais quatro bactérias $(\mathrm{CH} 147-7,96 \mathrm{U}$. $\mathrm{mL}^{-1} ; \mathrm{CH} 149-8,73 \mathrm{U} \cdot \mathrm{mL}^{-1} ; \mathrm{CH} 150_{\mathrm{B}}-7,63 \mathrm{U} \cdot \mathrm{mL}^{-1} ; \mathrm{CH} 151-7,68 \mathrm{U} \cdot \mathrm{mL}^{-1}$ ) foram isoladas no Ponto 1 , duas $\left(\mathrm{CH} 122_{\mathrm{T}}-8,17 \mathrm{U} . \mathrm{mL}^{-1}\right.$; $\mathrm{CH} 125-7,39 \mathrm{U} . \mathrm{mL}^{-1}$;) foram isoladas no Ponto 2 e uma $\left(\mathrm{CH} 141_{1}-8,21 \mathrm{U} . \mathrm{mL}^{-1}\right)$ no Ponto 3 , sendo todas isoladas no mesmo dia de coleta (17/02/2006). As outras quatro bactérias que apresentaram alta atividade enzimática foram isoladas em 24/01/2007 no Ponto $3\left(\mathrm{CH} 286\right.$ - 7,77 U . mL $\mathrm{mL}^{-1}$; $\mathrm{CH} 274_{\mathrm{T}}-7,83$ $\left.\mathrm{U} \cdot \mathrm{mL}^{-1}\right), 13 / 02 / 2007$ no Ponto $1\left(\mathrm{CH} 314_{\mathrm{T}}-8,81 \mathrm{U} \cdot \mathrm{mL}^{-1}\right)$ e em $27 / 03 / 2007$ no ponto 3 $\left(\mathrm{CH} 366-7,11 \mathrm{U} \cdot \mathrm{mL}^{-1}\right)$.

As bactérias quitinolíticas gram-negativas e gram-positivas (bacilos/cocos), isoladas de amostras de plâncton coletadas na Baixada Santista, mostraram atividade enzimática variando de 0,00 a $7,90 \mathrm{U} \cdot \mathrm{mL}^{-1}$. A porcentagem dessas bactérias quitinolíticas que produziram de $0,00 \mathrm{U} \cdot \mathrm{mL}^{-1}, 0,01$ a $4,99 \mathrm{U} \cdot \mathrm{mL}^{-1}$ e 5,0 a $8,81 \mathrm{U} \cdot \mathrm{mL}^{-1}$ de enzima foi $49 \%$, 
$46 \%$ e 5\%, respectivamente (Figura 23C). Nessas amostras, três bactérias quitinolíticas gramnegativas $(5 \%)$ apresentaram mais de 7,0 $\mathrm{U} . \mathrm{mL}^{-1}$ de enzima, sendo uma bactéria isolada em 01/06/06 no Ponto 2 (CHZ52 - 7,90 U . $\mathrm{mL}^{-1}$ ) e as outras duas no Ponto 1, uma isolada em 13/02/2007 (CHZ231 - 7,50 U . $\left.\mathrm{mL}^{-1}\right)$ e outra em 27/03/2007 (CHZ306 - 7,80 U . mL $\left.{ }^{-1}\right)$.

A porcentagem de bactérias gram-positivas filamentosas isoladas de amostras de água do mar do Canal de São Sebastião, Ubatuba e Baixada Santista que não apresentaram atividade enzimática em caldo MMQ1 foi de $88 \%, 89 \%$ e $86 \%$, respectivamente (Figura 23 A, B e C). No Canal de São Sebastião foram isoladas apenas duas bactérias, ambas no ponto 1 de coleta, que produziram > $1 \mathrm{U} . \mathrm{mL}^{-1}$ de enzima $\left(\mathrm{CH} 10-1,22 \mathrm{U} \cdot \mathrm{mL}^{-1}-19 / 09 / 2005\right.$; CH361 - 2,50 U . mL $\mathrm{m}^{-1}$ - 13/02/2007). Em Ubatuba, apenas uma bactéria (CH108) coletada em 13/02/2006 no Ponto 1 produziu mais de $0,5 \mathrm{U} \cdot \mathrm{mL}^{-1}$ de enzima $\left(0,51 \mathrm{U} \cdot \mathrm{mL}^{-1}\right)$. Nas amostras de água da Baixada Santista foi isolada somente uma bactéria quitinolítica grampositiva filamentosa que produziu mais de $1,0 \mathrm{U} . \mathrm{mL}^{-1}$ de enzima $\left(\mathrm{CH} 220-1,14 \mathrm{U} . \mathrm{mL}^{-1}\right.$ 27/04/2006 - Ponto 3).

Em amostras de plâncton coletadas no Canal de São Sebastião, Ubatuba e Baixada Santista, $88 \%$, 92\% e $78 \%$ das bactérias quitinolíticas filamentosas não apresentaram produção enzimática (Figura 23 A, B e C). Nessas amostras, a bactéria quitinolítica que apresentou maior produção de enzimas foi isolada na Baixada Santista no Ponto 1 em 27/03/2007 (CHZ328 - 1,79 U . mL mb $^{-1}$. No Canal de São Sebastião, as duas bactérias que apresentaram maior produção enzimática foram todas coletadas no Ponto 1 em 18/07/2006 (CHZ119-0,62 U . mL ${ }^{-1}$; CHZ120 - 0,53 U . mL $\mathrm{mL}^{-1}$;). Apenas uma bactéria proveniente de amostras de plâncton de Ubatuba apresentou mais de $0,01 \mathrm{U} \cdot \mathrm{mL}^{-1}$ de enzima (CHZ256 0,16 U . mL $\mathrm{m}^{-1}-13 / 02 / 2007$ - Ponto 2). 

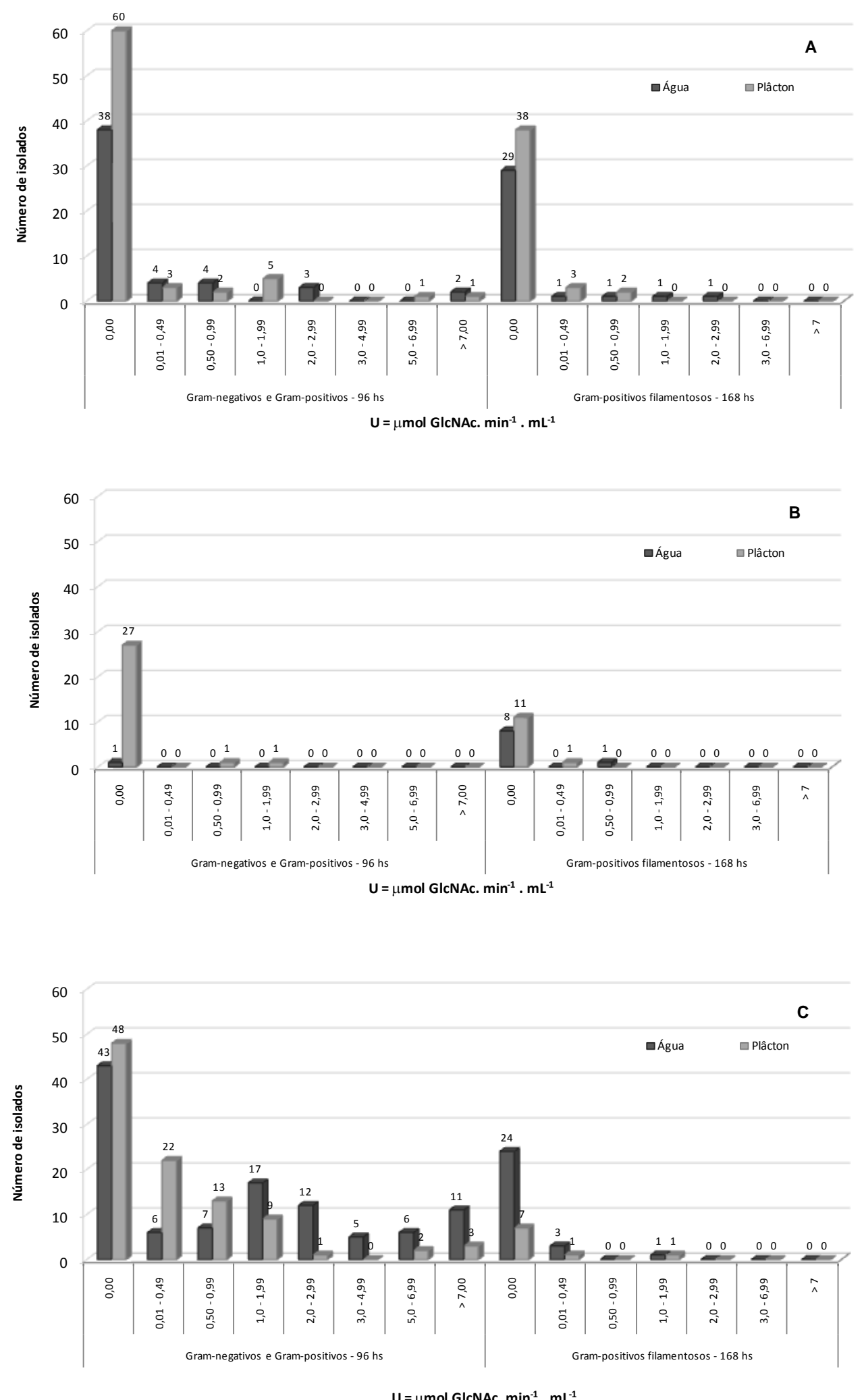

Figura 23 - Distribuição de bactérias quitinolíticas isoladas de amostras de água do mar e plâncton, por local de coleta, de acordo com a atividade enzimática necessária para a liberação de $N$-acetil-glicosamina, a partir da degradação de quitina coloidal.

A: Canal de São Sebastião; B: Ubatuba; C: Baixada Santista. 
Os resultados de atividade enzimática necessária à liberação de $N$-acetil-glicosamina pelas bactérias quitinolíticas gram-negativas e gram-positivas (bacilos e cocos) e grampositivas filamentosas isoladas de amostras de água do mar e plâncton provenientes de cada local de coleta, também foram expressos em mediana e percentil 25 e 75 (Figura 24).
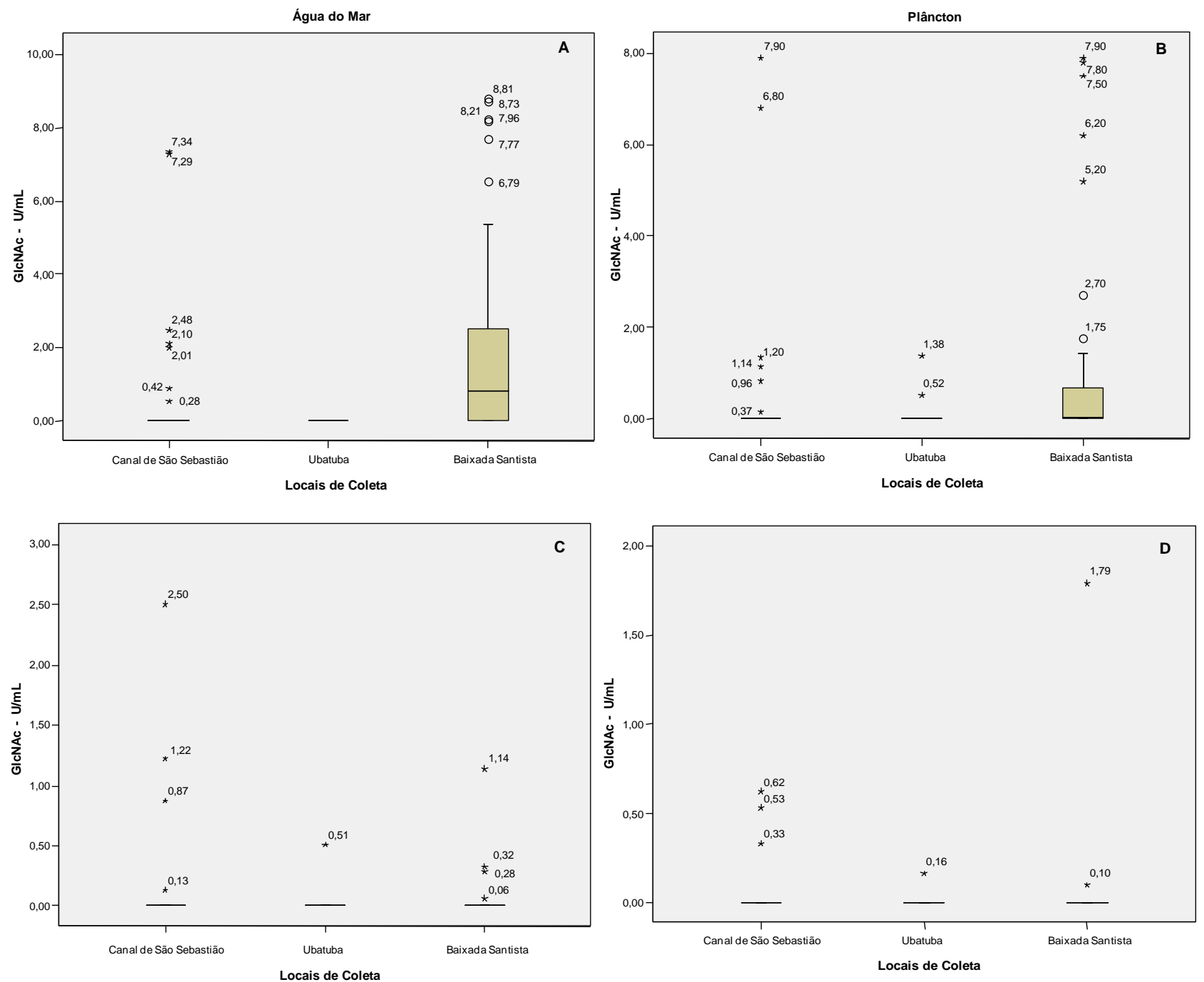

Figura 24 - Valor da mediana, percentil 25 e 75 do diâmetro do halo de hidrólise de quitina produzido pelas bactérias quitinolíticas gram-negativas e gram-positivas (bacilos e cocos) após 96 horas de incubação (A e B) e pelas bactérias quitinolíticas filamentosas após 168 horas de incubação (C e D) isoladas em amostras do Canal de São Sebastião, Ubatuba e Baixada Santista.

A e C: Amostras de água do mar; B e D: amostras de plâncton

Legenda:

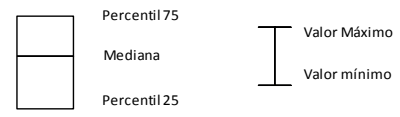


Foram verificadas diferenças estatisticamente significantes (Teste de Kruskal-Wallis) ao comparar os valores de atividade enzimática das bactérias quitinolíticas gram-negativas e gram-positivas (bacilos e cocos), isoladas de amostras de água do mar do Canal de São Sebastião e Baixada Santista ( $\mathrm{p}=0,000)$, após 96 horas de incubação. Essa comparação não pôde ser realizada com os resultados obtidos pelas bactérias quitinolíticas isoladas no Canal de São Sebastião e Ubatuba e de Ubatuba e Baixada Santista devido ao número insuficiente de isolados de Ubatuba. Em amostras de plâncton, foram encontradas diferenças estatisticamente significantes somente entre a atividade enzimática das bactérias quitinolíticas isoladas do Canal de São Sebastião e Baixada Santista $(p=0,000)$ e entre Ubatuba e Baixada Santista $(\mathrm{p}=0,000)$.

Analisando a atividade enzimática das bactérias quitinolíticas gram-negativas e grampositivas (bacilos e cocos) isoladas de amostras de água do mar, em relação ao ponto de amostragem de cada local estudado, verificamos diferenças estatisticamente somente em amostras coletadas na Baixada Santista e entre os pontos 1 e $2(p=0,027)$ e os pontos 2 e 3 $(\mathrm{p}=0,048)$. Diferenças estatisticamente significantes também foram encontradas ao comparar a atividade enzimática das bactérias quitinolíticas (96 horas de incubação) isoladas de amostras de plâncton. Porém, entre os pontos 1 e 2 do Canal de São Sebastião $(p=0,007)$ e entre os pontos 1 e 2 de Ubatuba $(\mathrm{p}=0,020)$.

Em relação às bactérias quitinolíticas gram-positivas filamentosas, não foram observadas diferenças estatisticamente significantes entre a produção enzimática dessas bactérias ao comparar os resultados por local de coleta ou por ponto de amostragem em cada ecossistema marinho estudado.

\subsubsection{Quantificação da enzima $\beta$ - $N$-acetil-glicosaminidase produzida pelas bactérias quitinolíticas}

Um total de 358 bactérias quitinolíticas gram-negativas e gram-positivas (bacilos/cocos) e 134 bactérias quitinolíticas gram-positivas filamentosas foram submetidas à quantificação da enzima $\beta$ - $N$-acetil-glicosaminidase após 96 e 168 horas de incubação, respectivamente.

As bactérias quitinolíticas gram-negativas e gram-positivas (bacilos/cocos), isoladas de amostras de água do mar e plâncton do Canal de São Sebastião, apresentaram valores de $\beta$ $N$-acetil-glicosaminidase, variando de 0,0 a $2,530 \mathrm{U}$. $\mathrm{mL}^{-1}$ e 0,0 a $1,112 \mathrm{U}$. $\mathrm{mL}^{-1}$, 
respectivamente. No entanto, a maioria das bactérias quitinolíticas isoladas de amostras de água do mar (78\%) e plâncton (85\%), respectivamente apresentaram um índice muito baixo de produção de $\beta$ - $N$-acetil-glicosaminidase $\left(0,0\right.$ a $\left.0,099 \mathrm{U} \cdot \mathrm{mL}^{-1}\right)$ (Figura 25A). Apenas três bactérias $(6 \%)$ isoladas de amostras de água apresentaram mais de $1 \mathrm{U} \cdot \mathrm{mL}^{-1}$ de enzima $\left(\mathrm{CH}_{0} 7_{\mathrm{T}}-1,074 \mathrm{U} . \mathrm{mL}^{-1}\right.$; $\mathrm{CH} 18-1,132 \mathrm{U} . \mathrm{mL}^{-1}$ e CH20 - 2,530 U . mL $\left.{ }^{-1}\right)$, sendo que todas foram isoladas no mesmo dia (19/09/2005). Porém, uma delas $\left(\mathrm{CH} 07_{\mathrm{T}}\right)$, foi isolada no Ponto 1 e as outras duas no Ponto 2. Em amostras de plâncton, apenas uma bactéria (1\%) apresentou $>1,000 \mathrm{U} \cdot \mathrm{mL}^{-1}$ de $\beta$ - $N$-acetil-glicosaminidase $\left(\mathrm{CHZ113}-1,112 \mathrm{U} \cdot \mathrm{mL}^{-1}\right)$ a qual foi isolada em 18/07/2006 no ponto 1 .

A única bactéria gram-negativa $(\mathrm{CH} 178)$ proveniente de amostra de água do mar de Ubatuba, isolada em 21/03/2006, produziu somente $0,001 \mathrm{U} . \mathrm{mL}^{-1}$ de $\beta$ - $N$-acetilglicosaminidase. Em amostras de plâncton, a produção de $\beta$ - $N$-acetil-glicosaminidase variou de 0,0 a $0,194 \mathrm{U} \cdot \mathrm{mL}^{-1}$, mas $97 \%$ dessas bactérias apresentaram valores dessa enzima variando de 0,0 a $0,099 \mathrm{U} . \mathrm{mL}^{-1}$ e apenas uma bactéria (3\%), isolada em 23/01/2007 no ponto 2, apresentou valor maior que $0,100 \mathrm{U} . \mathrm{mL}^{-1}\left(\mathrm{CHZ183}-0,194 \mathrm{U} . \mathrm{mL}^{-1}\right)$ (Figura 25B).

A maior produção de $\beta$ - $N$-acetil-glicosaminidase foi obtida por bactérias quitinolíticas isoladas de amostras de água da Baixada Santista, cujos valores variaram de 0,0 a 2,968 U . mL ${ }^{-1}$. Nessas amostras, $57 \%, 36 \%$ e $7 \%$ das bactérias quitinolíticas produziram de 0,00 a $0,099 \mathrm{U} \cdot \mathrm{mL}^{-1}, 0,100$ a $1,000 \mathrm{U} \cdot \mathrm{mL}^{-1} \mathrm{e}>1,000 \mathrm{U} \cdot \mathrm{mL}^{-1}$ de $\beta$ - $N$-acetilglicosaminidase, respectivamente (Figura 25C). Das oito bactérias quitinolíticas (7\%) que produziram mais de $1 \mathrm{U} . \mathrm{mL}^{-1}$ de enzima, sete delas foram isoladas em 17/02/2006, sendo cinco no ponto $1\left(\mathrm{CH} 143-\quad\right.$ 1,179 $\mathrm{U}^{-\mathrm{mL}^{-1}}$; $\mathrm{CH} 147_{1 \mathrm{~B}}-1,352 \mathrm{U} . \mathrm{mL}^{-1}$; $\mathrm{CH} 149-1,970 \mathrm{U}$ . $\mathrm{mL}^{-1}$; $\mathrm{CH} 150_{\mathrm{B}}-1,067 \mathrm{U} . \mathrm{mL}^{-1}$; $\left.\mathrm{CH} 151-1,708 \mathrm{U} . \mathrm{mL}^{-1}\right)$, uma no ponto $2(\mathrm{CH} 125-2,030$ $\left.\mathrm{U} . \mathrm{mL}^{-1}\right)$ e uma no ponto $3\left(\mathrm{CH} 141_{\mathrm{B}}-2,968 \mathrm{U} . \mathrm{mL}^{-1}\right)$ e o isolado $\mathrm{CH} 276\left(1,269 \mathrm{U}^{-\mathrm{mL}^{-1}}\right)$ foi isolado em 24/01/2007 no Ponto 3.

Em amostras de plâncton coletadas na Baixada da Santista, a porcentagem de bactérias quitinolíticas que produziram de 0,0 a $0,099 \mathrm{U} . \mathrm{mL}^{-1}$ e 0,100 a $1,000 \mathrm{U} . \mathrm{mL}^{-1}$ de $\beta$ - $N$-acetilglicosaminidase foi de $64 \%$ e $36 \%$, respectivamente. Nenhuma bactéria quitinolítica proveniente dessas amostras produziu $>1 \mathrm{U} . \mathrm{mL}^{-1}$ dessa enzima (Figura 25C). A bactéria (CHZ52) que produziu a maior quantidade de $\beta$ - $N$-acetil-glicosaminidase $\left(0,804 \mathrm{U} . \mathrm{mL}^{-1}\right)$ foi isolada em 01/06/2006 no Ponto 2.

Analisando a produção de $\beta$ - $N$-acetil-glicosaminidase pelas bactérias quitinolíticas gram-positivas filamentosas, foi verificado que 97\%, 100\% e 100\% das bactérias isoladas de 
amostras de água do mar do Canal de São Sebastião, Ubatuba e Baixada Santista produziram de 0,0 a 0,099 $\mathrm{U} \cdot \mathrm{mL}^{-1}$ dessa enzima. Nessas amostras, apenas uma bactéria (CH261) isolada no ponto 2 do Canal de São Sebastião em 14/12/2006 produziu > 0,100 U . $\mathrm{mL}^{-1}$ de $\beta-N$ acetil-glicosaminidase $\left(0,287 \mathrm{U} \cdot \mathrm{mL}^{-1}\right)$. Nas amostras de plâncton, a porcentagem de bactérias quitinolíticas gram-positivas filamentosas isoladas do Canal de São Sebastião, Ubatuba e Baixada Santista que produziram de 0,0 a 0,099 U da enzima $\beta$ - $N$-acetilglicosaminidase foi de 98\%, 92\% e 100\%, respectivamente. Apenas duas bactérias apresentaram > 0,100 U. mL ${ }^{-1}$ de enzima, sendo uma bactéria $\left(\mathrm{CHZ171}-0,101 \mathrm{U} \cdot \mathrm{mL}^{-1}\right)$ coletada no ponto 2 do Canal de São Sebastião em 23/01/2007 e uma (CHZ283 - 0,147 U . $\mathrm{mL}^{-1}$ ) coletada no Ponto 1 de Ubatuba em 16/03/2007 (Figura 25A, B e C). 

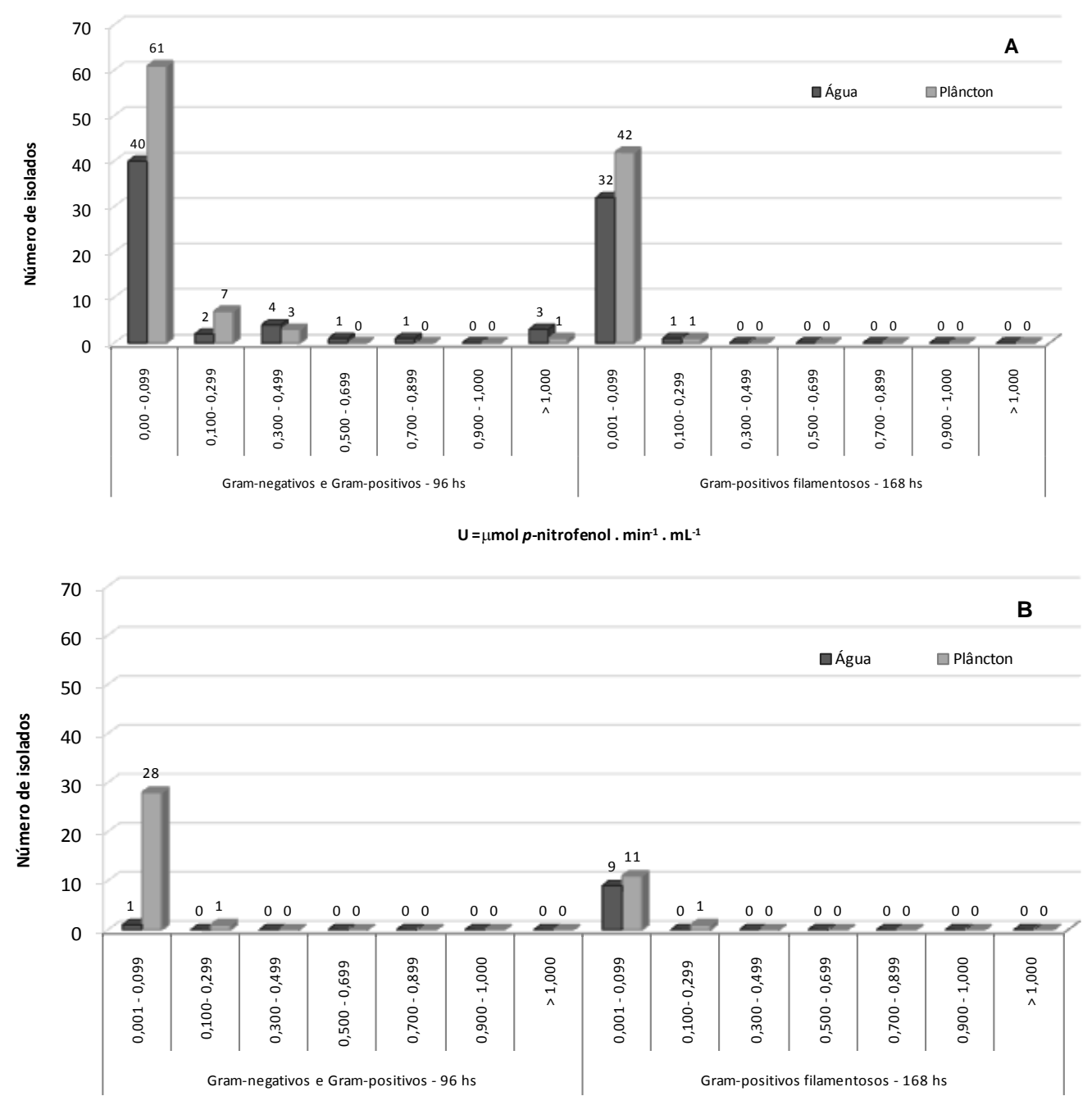

$\mathrm{U}=\mu \mathrm{mol} p$-nitrofenol $\cdot \mathrm{min}^{-1} \cdot \mathrm{mL}^{-1}$

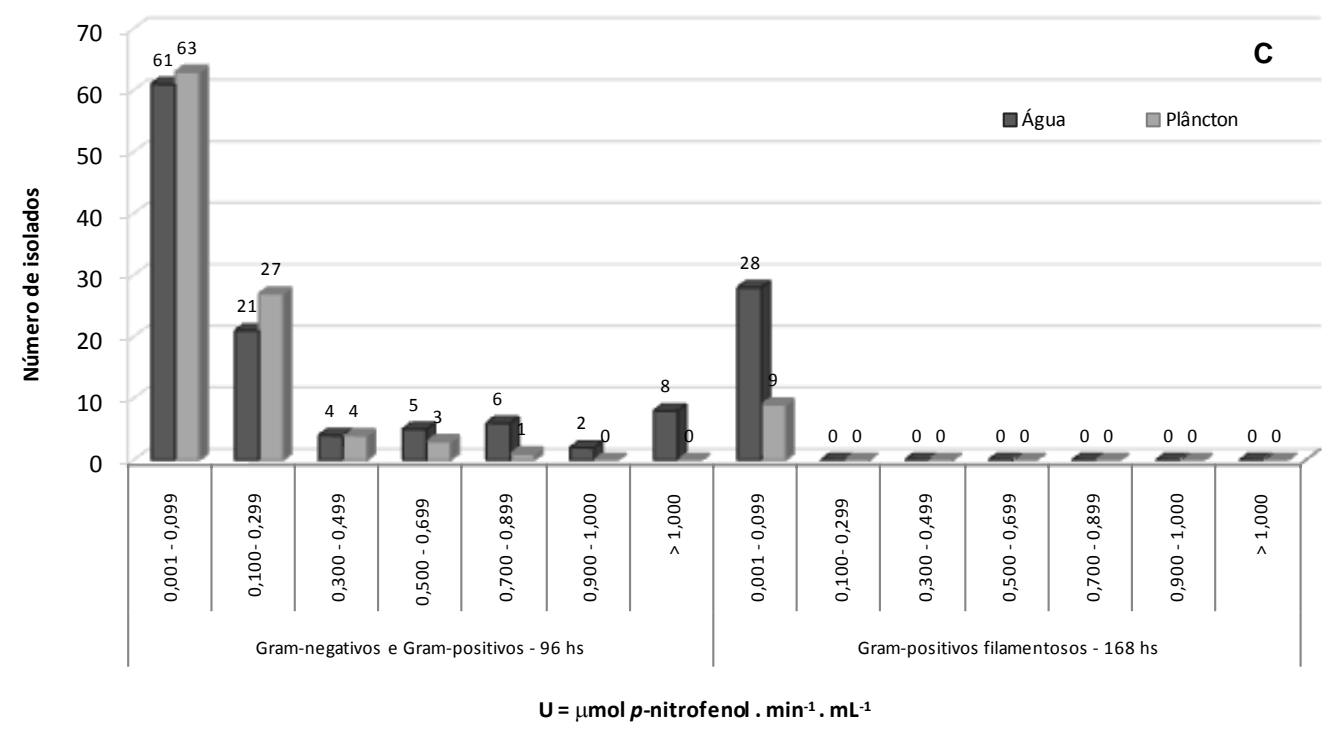

Figura 25 - Distribuição de bactérias quitinolíticas isoladas de amostras de água do mar e plâncton, por local de coleta, de acordo com a produção da enzima $\beta$ - $N$-acetil-glicosaminidase.

A: Canal de São Sebastião; B: Ubatuba; C: Baixada Santista. 
Os valores de produção de $\beta-N$-acetil-glicosaminidase pelas bactérias quitinolíticas gram-negativas e gram-positivas (bacilos e cocos) e gram-positivas filamentosas, isoladas de amostras de água do mar e plâncton provenientes de cada local de coleta, foram expressos em mediana e percentil 25 e 75 (Figura 26).
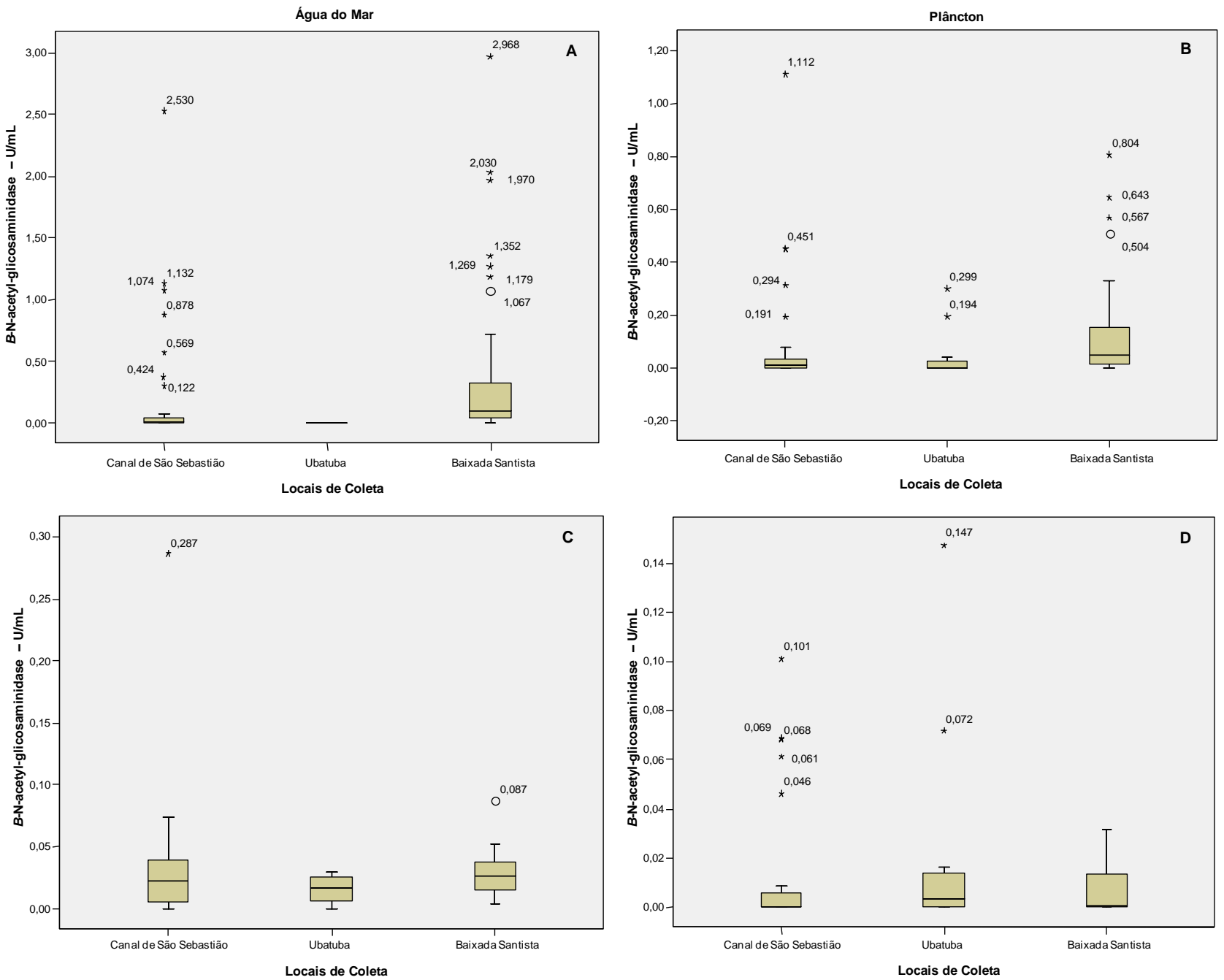

Figura 26 - Valor da mediana, percentil 25 e 75 do diâmetro do halo de hidrólise de quitina produzido pelas bactérias quitinolíticas gram-negativas e gram-positivas (bacilos e cocos) após 96 horas de incubação (A e B) e pelas bactérias quitinolíticas filamentosas após 168 horas de incubação (C e D) isoladas em amostras do Canal de São Sebastião, Ubatuba e Baixada Santista.

A e C: Amostras de água do mar; B e D: amostras de plâncton

Legenda:

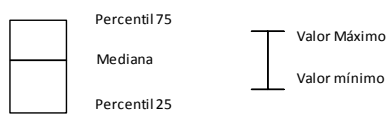


Foram verificadas diferenças estatisticamente significantes (Teste de Kruskal-Wallis) ao comparar os valores de produção da enzima $\beta$ - $N$-acetil-glicosaminidase pelas bactérias quitinolíticas gram-negativas e gram-positivas (bacilos e cocos) isoladas de amostras de água do mar do Canal de São Sebastião e Baixada Santista (p=0,000) após 96 horas de incubação. Essa comparação não pôde ser realizada com os resultados obtidos pelas bactérias quitinolíticas isoladas no Canal de São Sebastião e Ubatuba e de Ubatuba e Baixada Santista devido ao número insuficiente de isolados de Ubatuba. Em amostras de plâncton, foram encontradas diferenças estatisticamente significantes para a produção da enzima $\beta$ - $N$-acetilglicosaminidase entre as bactérias isoladas do Canal de São Sebastião e Ubatuba ( $p=0,049)$, Canal de São Sebastião e Baixada Santista $(\mathrm{p}=0,000)$ e entre Ubatuba e Baixada Santista $(\mathrm{p}=$ $0,000)$.

Não foram verificadas diferenças estatisticamente significantes, ao comparar a produção da enzima $\beta$ - $N$-acetil-glicosaminidase pelas bactérias quitinolíticas gram-negativas e gram-positivas (bacilos e cocos) isoladas de amostras de água do mar, em relação ao ponto de amostragem de cada local estudado.

Em relação às bactérias quitinolíticas gram-positivas filamentosas, não foram observadas diferenças estatisticamente significantes entre a produção da enzima $\beta$ - $N$-acetilglicosaminidase ao comparar os resultados por local de coleta ou por ponto de amostragem em cada ecossistema marinho estudado.

\subsubsection{Quantificação das enzimas quitobiosidase e endoquitinase produzidas pelas bactérias quitinolíticas}

Para quantificação das enzimas quitobiosidase e endoquitinase foram selecionados, dentre as bactérias que apresentaram período de incubação de 96 horas, vinte bactérias quitinolíticas isoladas de amostras de água do mar e nove isoladas de amostras de plâncton, de acordo com os seguintes critérios:

1) Bactérias quitinolíticas isoladas de amostras de água do mar:

a. $\quad$ 5,8 $\mathrm{mm}$ de diâmetro do halo de hidrólise de quitina.

b. $>5 \mathrm{U} . \mathrm{mL}^{-1}$ de enzimas necessárias para formar 1,0 $\mu$ mol de GlcNAc por minuto por $\mathrm{mL}$ a $37^{\circ} \mathrm{C}$.

c. $>1,2 \mathrm{U} . \mathrm{mL}^{-1}$ de $\beta$ - $N$-acetil-glicosaminidase 
2) Bactérias quitinolíticas isoladas de amostras de plâncton:

a. > 5,5 mm de diâmetro do halo de hidrólise de quitina.

b. > 2,7 U . $\mathrm{mL}^{-1}$ de enzimas necessárias para formar 1,0 $\mu$ mol de GlcNAc por minuto por $\mathrm{mL}$ a $37^{\circ} \mathrm{C}$.

c. $>0,5 \mathrm{U} . \mathrm{mL}^{-1}$ de $\beta-N$-acetil-glicosaminidase.

Os valores das enzimas $\beta$ - $N$-acetil-glicosaminidase, quitobiosidase e endoquitinase produzidas pelas bactérias quitinolíticas isoladas de amostras de água do mar e plâncton, estão apresentados na figura 27 e figura 28, respectivamente. Os resultados de diâmetro do halo de hidrólise de quitina e produção de enzimas necessárias para liberar GlcNAc podem ser visualizados na tabela 10 juntamente com os resultados de produção das enzimas $\beta$ - $N$-acetilglicosaminidase, quitobiosidase e endoquitinase. 


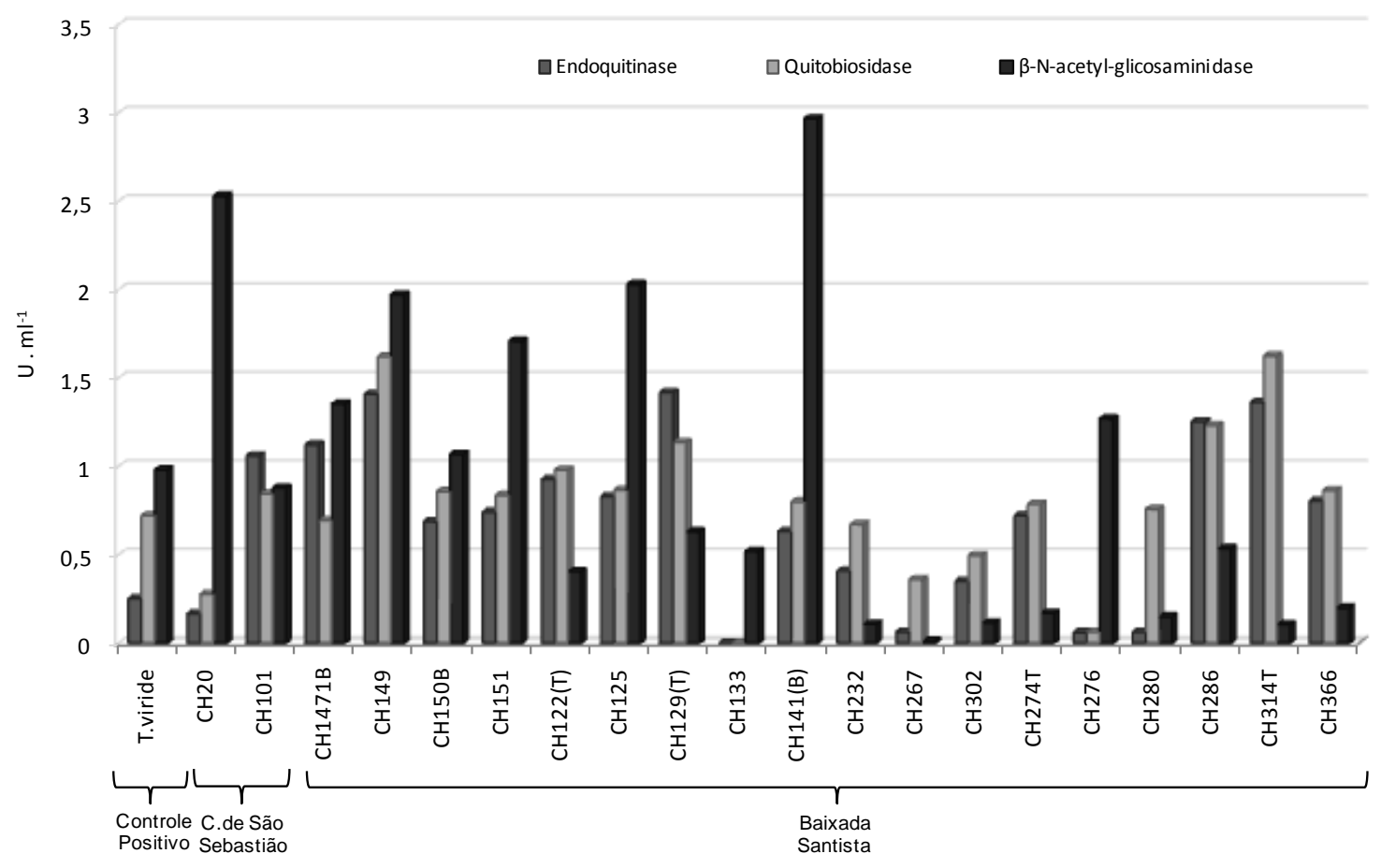

Figura 27 - Produção das enzimas endoquitinase, quitobiosidase e $\beta$ - $N$-acetil-glicosaminidase pelas bactérias quitinolíticas selecionadas provenientes de amostras de água do mar.

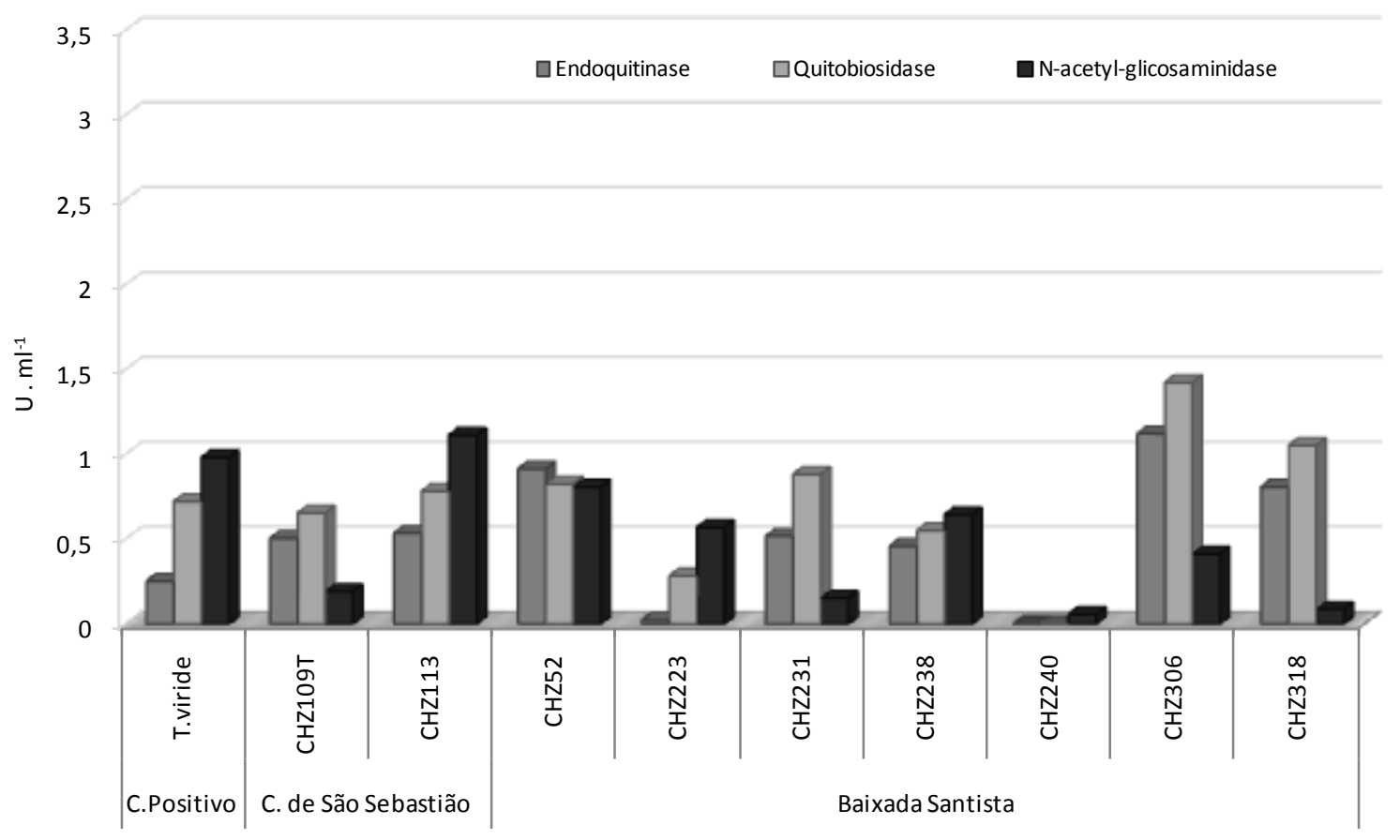

Figura 28 - Produção das enzimas endoquitinase, quitobiosidase e $\beta$ - $N$-acetil-glicosaminidase pelas bactérias quitinolíticas selecionadas, provenientes de amostras de plâncton. 
Tabela 10 - Medida do diâmetro do halo de hidrólise de quitina e valores de produção de enzimas necessárias para formar GlcNAc e das enzimas $\beta$ - $N$-acetil-glicosaminidase, quitobiosidase e endoquitinase produzidas pelas bactérias quitinolíticas selecionadas.

\begin{tabular}{|c|c|c|c|c|c|c|c|c|c|}
\hline \multirow[t]{2}{*}{ 苞 } & \multirow[t]{2}{*}{$\begin{array}{l}\text { Identifi- } \\
\text { cação }\end{array}$} & \multirow[t]{2}{*}{ Local } & \multirow[t]{2}{*}{$\begin{array}{c}\text { Data } \\
\text { da Coleta }\end{array}$} & \multirow[t]{2}{*}{$\begin{array}{l}\text { Ponto } \\
\text { de } \\
\text { Coleta }\end{array}$} & \multirow[t]{2}{*}{$\begin{array}{c}\text { Diâmetro } \\
\text { do Halo } \\
\text { c/ } 96 \text { h }\end{array}$} & \multicolumn{2}{|r|}{$\begin{array}{c}\text { B- } N- \\
\text { acetil- } \\
\text { glicosami } \\
\text {-nidase }\end{array}$} & \multirow{2}{*}{$\begin{array}{c}\begin{array}{c}\text { Quito- } \\
\text { biosidase }\end{array} \\
\text { U/mL }\end{array}$} & \multirow{2}{*}{$\begin{array}{c}\begin{array}{c}\text { Endoqui- } \\
\text { tinase }\end{array} \\
\mathrm{U} / \mathrm{mL}\end{array}$} \\
\hline & & & & & & $\begin{array}{c}\mathrm{U} / \mathbf{m L} / \\
\mathrm{min}\end{array}$ & $\mathbf{U} / \mathbf{m L}$ & & \\
\hline \multirow{20}{*}{ 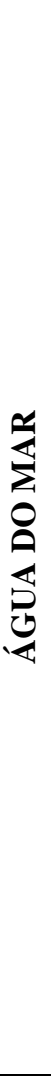 } & CH101 & São Sebastião & $13 / 02 / 06$ & $\mathrm{P} 1$ & 6,10 & 7,29 & 0,878 & 0,844 & 1,059 \\
\hline & $\mathrm{CH} 20$ & São Sebastião & $19 / 09 / 05$ & $\mathrm{P} 2$ & 2,98 & 7,34 & 2,530 & 0,276 & 0,165 \\
\hline & $\mathrm{CH} 147_{1 \mathrm{~B}}$ & B. Santista & $17 / 02 / 06$ & $\mathrm{P} 1$ & 3,91 & 7,96 & 1,352 & 0,693 & 1,122 \\
\hline & CH149 & B. Santista & $17 / 02 / 06$ & $\mathrm{P} 1$ & 3,81 & 8,73 & 1,970 & 1,621 & 1,408 \\
\hline & $\mathrm{CH} 150_{\mathrm{B}}$ & B. Santista & $17 / 02 / 06$ & $\mathrm{P} 1$ & 2,58 & 7,63 & 1,067 & 0,857 & 0,686 \\
\hline & CH151 & B. Santista & $17 / 02 / 06$ & $\mathrm{P} 1$ & 2,87 & 7,68 & 1,708 & 0,836 & 0,741 \\
\hline & CH267 & B. Santista & $24 / 01 / 07$ & $\mathrm{P} 1$ & 6,72 & 1,34 & 0,011 & 0,360 & 0,062 \\
\hline & $\mathrm{CH} 314_{\mathrm{T}}$ & B. Santista & $13 / 02 / 07$ & $\mathrm{P} 1$ & 5,80 & 8,81 & 0,178 & 1,625 & 1,362 \\
\hline & $\mathrm{CH}_{122_{(\mathrm{T})}}$ & B. Santista & 17/02/06 & $\mathrm{P} 2$ & 3,03 & 8,17 & 0,406 & 0,980 & 0,927 \\
\hline & CH125 & B. Santista & $17 / 02 / 06$ & $\mathrm{P} 2$ & 1,62 & 7,39 & 2,030 & 0,865 & 0,829 \\
\hline & $\mathrm{CH} 129_{(\mathrm{T})}$ & B. Santista & 17/02/06 & $\mathrm{P} 2$ & 3,22 & 6,95 & 0,631 & 1,136 & 1,417 \\
\hline & CH302 & B. Santista & $24 / 01 / 07$ & $\mathrm{P} 2$ & 5,97 & 5,02 & 0,079 & 0,494 & 0,350 \\
\hline & CH133 & B. Santista & $17 / 02 / 06$ & P3 & 4,27 & 5,36 & 0,653 & 0,000 & 0,000 \\
\hline & $\mathrm{CH} 141_{(\mathrm{B})}$ & B. Santista & $17 / 02 / 06$ & P3 & 2,48 & 8,21 & 2,968 & 0,799 & 0,631 \\
\hline & CH232 & B. Santista & 01/06/06 & P3 & 6,04 & 6,53 & 0,107 & 0,671 & 0,408 \\
\hline & $\mathrm{CH} 274_{\mathrm{T}}$ & B. Santista & $24 / 01 / 07$ & $\mathrm{P} 3$ & 4,00 & 7,83 & 0,169 & 0,785 & 0,720 \\
\hline & CH276 & B. Santista & $24 / 01 / 07$ & $\mathrm{P} 3$ & 6,62 & 6,79 & 1,269 & 0,061 & 0,060 \\
\hline & $\mathrm{CH} 280$ & B. Santista & $24 / 01 / 07$ & P3 & 6,14 & 5,35 & 0,149 & 0,757 & 0,061 \\
\hline & $\mathrm{CH} 286$ & B. Santista & $24 / 01 / 07$ & $\mathrm{P} 3$ & 6,91 & 7,77 & 0,535 & 1,231 & 1,252 \\
\hline & CH366 & B. Santista & $27 / 03 / 07$ & $\mathrm{P} 3$ & 6,12 & 7,11 & 0,198 & 0,861 & 0,805 \\
\hline \multirow{9}{*}{ 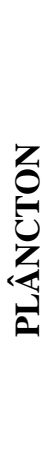 } & CHZ113 & São Sebastião & 18/07/06 & $\mathrm{P} 1$ & 2,97 & 7,90 & 1,112 & 0,781 & 0,533 \\
\hline & $\mathrm{CHZ109}_{\mathrm{T}}$ & São Sebastião & 18/07/06 & $\mathrm{P} 2$ & 6,49 & 6,80 & 0,191 & 0,652 & 0,504 \\
\hline & CHZ231 & B. Santista & $13 / 02 / 07$ & $\mathrm{P} 1$ & 2,31 & 7,50 & 0,152 & 0,881 & 0,515 \\
\hline & CHZ238 & B. Santista & $13 / 02 / 07$ & $\mathrm{P} 1$ & 3,49 & 5,20 & 0,643 & 0,550 & 0,457 \\
\hline & CHZ240 & B. Santista & $13 / 02 / 07$ & $\mathrm{P} 1$ & 5,76 & 0,35 & 0,055 & 0,000 & 0,000 \\
\hline & CHZ306 & B. Santista & $27 / 03 / 07$ & $\mathrm{P} 1$ & 2,68 & 7,80 & 0,411 & 1,421 & 1,120 \\
\hline & CHZ52 & B. Santista & $01 / 06 / 06$ & $\mathrm{P} 2$ & 2,82 & 7,90 & 0,804 & 0,823 & 0,912 \\
\hline & CHZ223 & B. Santista & $13 / 02 / 07$ & $\mathrm{P} 2$ & 2,29 & 2,70 & 0,567 & 0,281 & 0,020 \\
\hline & CHZ318 & B. Santista & $27 / 03 / 07$ & P3 & 5,88 & 6,20 & 0,085 & 1,051 & 0,806 \\
\hline
\end{tabular}

Legenda: U - Unidades; B. Baixada Santista; São Sebastião: Canal de São Sebastião Nota: Todas as bactérias são Gram-negativas, exceto a bactéria CH267.

O diâmetro de hidrólise de quitina, produção de $\beta$ - $N$-acetil-glicosaminidase, quitobiosidase, endoquitinases e produção de enzimas necessárias para formar 1,0 $\mu \mathrm{mol}$ de GlcNAc produzidos pelas bactérias quitinolíticas isoladas de amostras da Baixada Santista 
foram analisadas por tipo de amostra e ponto de coleta através do cálculo da mediana e do percentil 25 e 75 (Figura 29).
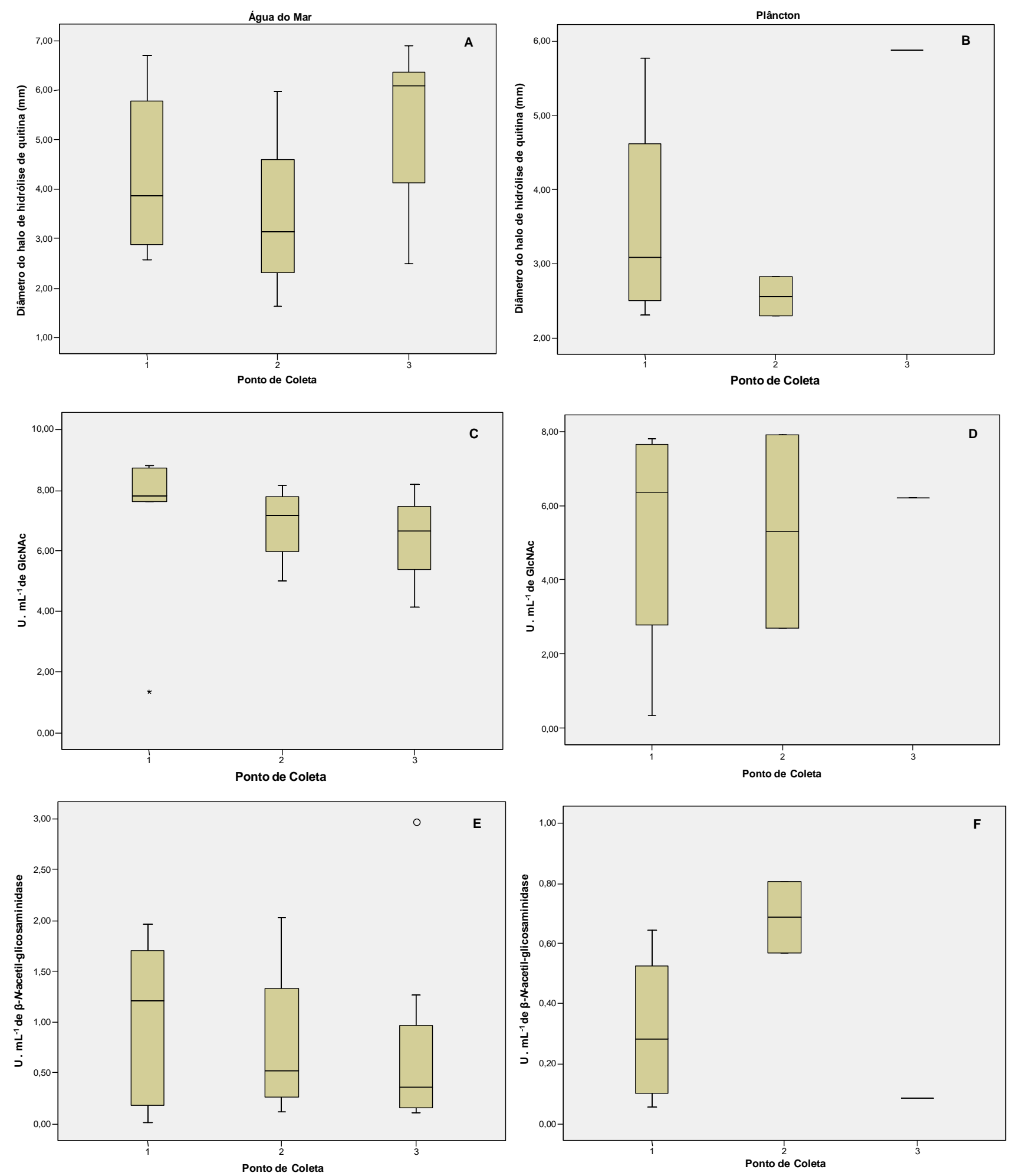

Figura 29 - Comparação do diâmetro de hidrólise de quitina (A e B); produção de enzimas necessárias para formar 1,0 $\mu \mathrm{mol}$ de GlcNAc (C e D); $\beta$ - $N$-acetil-glicosaminidase (E e F) produzidas pelas bactérias quitinolíticas isoladas de amostras da Baixada Santista, por ponto de coleta.

A, C e E: amostras de água do mar; B, D e F: amostras de Plâncton. 

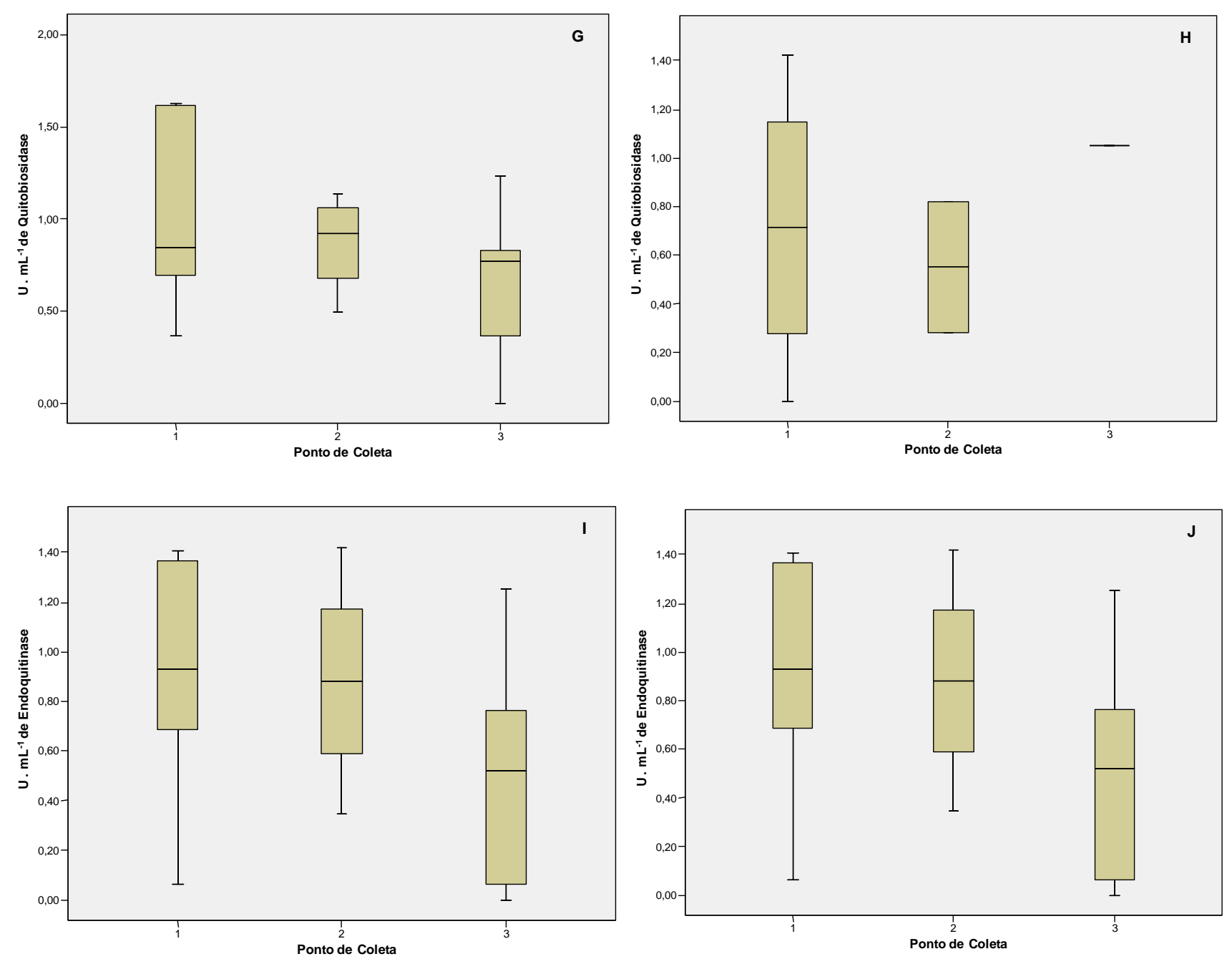

Figura 29 - Comparação do diâmetro de hidrólise de quitina (A e B); produção de enzimas necessárias para formar 1,0 $\mu \mathrm{mol}$ de GlcNAc (C e D); $\beta$ - $N$-acetil-glicosaminidase (E e F); quitobiosidase $(\mathrm{G}$ e $\mathrm{H})$ e produção de endoquitinases (I e J) produzidas pelas bactérias quitinolíticas isoladas de amostras da Baixada Santista, por ponto de coleta.

A, C, E, G e I: amostras de água do mar; B, D, F, H e J: amostras de Plâncton.

Legenda:

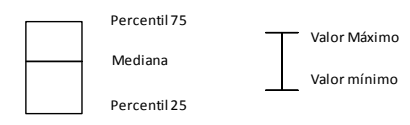

As diferenças existentes entre os pontos de coleta de amostras de água do mar observadas na figura 29 não foram estatísticas significantes quanto ao diâmetro do halo de hidrólise de quitina $(\mathrm{p}=0,139)$, à produção de enzimas necessárias para formar $1,0 \mu$ mol de GlcNAc $(\mathrm{p}=0,302)$, produção de $\beta$ - $N$-acetil-glicosaminidase $(\mathrm{p}=0,778)$, quitobiosidase $(\mathrm{p}=$ 0,357) e endoquitinases ( $\mathrm{p}=0,146)$, de acordo com o Kruskal-Wallis Test. Também não foram encontradas diferenças estatisticamente significantes quanto ao diâmetro do halo de hidrólise 
de quitina ( $\mathrm{p}=0,235)$, à produção de enzimas necessárias para formar 1,0 $\mu$ mol de GlcNAc (p $=0,923)$, produção de $\beta$ - $N$-acetil-glicosaminidase $(\mathrm{p}=0,248)$, quitobiosidase $(\mathrm{p}=0,526)$ e endoquitinases $(\mathrm{p}=0,875)$ entre as bactérias quitinolíticas isoladas de amostras de plâncton da Baixada Santista descritas na figura 28. As bactérias quitinolíticas selecionadas (tabela 10) obtidas em amostras do Canal de São Sebastião e Baixada Santista não foram comparadas entre si através de análises estatísticas, devido ao número reduzido de bactérias provenientes do Canal de São Sebastião.

Entre as bactérias quitinolíticas, isoladas de amostras de água da Baixada Santista, foi observada uma correlação negativa entre diâmetro do halo de hidrólise de quitina e produção $\beta$ - $N$-acetil-glicosaminidase ( $\mathrm{p}=0,002$ e $\mathrm{r}=-0,668$ ). Nesses mesmos isolados também foi encontrada correlação, porém positiva entre $\beta$ - $N$-acetil-glicosaminidase $(\mathrm{p}=0,007$ e $\mathrm{r}=$ $0,610)$, quitobiosidase $(p=0,001$ e $r=0,705)$ e endoquitinase $(p=0,002$ e $r=0,672)$ com produção de enzimas necessárias para formar GlcNAc. E a produção de quitobiosidase foi correlacionada positivamente com a produção de endoquitinase ( $\mathrm{p}=0,000$ e $\mathrm{r}=0,882)$.

Em relação à atividade enzimática das bactérias quitinolíticas, isoladas de amostras de plâncton da Baixada Santista, foi observada correlação positiva apenas entre a produção de endoquitinase e enzimas necessárias para formar GlcNAc $(p=0,003$ e $r=0,929)$ e entre a produção de endoquitinase e quitobiosidase $(\mathrm{p}=0,007$ e $\mathrm{p}=0,893)$.

\subsection{CARACTERIZAÇÃO MOLECULAR DAS BACTÉRIAS QUITINOLÍTICAS}

\subsubsection{Extração de DNA genômico}

Foi realizada a extração de DNA genômico de todas as bactérias quitinolíticas gramnegativas e gram-positivas (bacilos e cocos) $(\mathrm{n}=358)$ e de 41 bactérias quitinolíticas grampositivas filamentosas que apresentaram maior halo de hidrólise de quitina ou que apresentaram características morfológicas diferentes da maioria dos gram-positivos filamentosos obtidos em placas de MMQ1.

O Wizard ${ }^{\circledR}$ Genomic DNA Purification Kit (A1125, Promega Co., EUA), possibilitou extrair DNA com boa qualidade. Todavia, para se obter concentrações de DNA acima de 100 ng/uL foi necessário aumentar de o volume de $1 \mathrm{~mL}$, como recomendado pelo fabricante, para $3 \mathrm{~mL}$ de caldo com cultura bacteriana. 


\subsubsection{Caracterização molecular pelas técnicas de ERIC-PCR e BOX-PCR}

O DNA das 358 bactérias quitinolíticas gram-negativas e gram-positivas (bacilos e cocos) e das 41 bactérias quitinolíticas filamentosas foi submetido às técnicas de ERIC e BOX-PCR com o intuito de verificar a similaridade entre esses isolados. Após a análise dos dendrogramas construídos através dos coeficientes de Dice e Jaccard foi verificado que o coeficiente de Dice apresentou-se mais eficiente, pois foi obtido maior valor de similaridade e maior número de agrupamentos entre os isolados analisados em comparação com o coeficiente de Jaccard.

A reprodutibilidade das técnicas de ERIC-PCR e BOX-PCR foi confirmada realizando uma repetição de ambas as técnicas em 10\% $(n=40)$ dos isolados. Em todas as reações de PCR realizadas foram utilizadas cepas padrão como controles positivos da técnica. O teste de reprodutibilidade confirmou o perfil de bandas dos isolados analisados.

Para cada técnica realizada (ERIC-PCR e BOX-PCR), foi construído um dendrograma com todas as bactérias quitinolíticas isoladas de amostras de água do mar e plâncton obtidos dos três locais de coleta utilizando o coeficiente de Dice. Porém, os agrupamentos obtidos não mostraram relação com os locais de coleta, tipo de amostra, data de coleta e diâmetro do halo e, por isso, para facilitar a visualização, foi construído um dendrograma para cada local de coleta e tipo de amostra estudado, os quais foram analisados separadamente (Figuras 30 a 39).

Analisando o total de bactérias quitinolíticas $(\mathrm{n}=399)$ submetidas à técnica de BOXPCR, verificamos que não foram obtidos produtos de amplificação por $5 \%(n=20)$ das bactérias quitinolíticas e 2,5\% $(\mathrm{n}=10)$ apresentaram apenas uma banda. Em relação à técnica de ERIC-PCR, verificamos que 16\% $(n=63)$ das bactérias quitinolíticas não apresentaram produtos de amplificação e 13\% (n=51) amplificaram apenas uma banda. Portanto, foram incluídos nos dendrogramas somente os isolados que apresentaram $\geq 2$ produtos de amplificação (Figuras 30 a 39).

Dentre as bactérias quitinolíticas que apresentaram $<2$ produtos de amplificação pela técnica de BOX-PCR, foi verificado que 30\%, 30\% e 40\% dos isolados eram gram-negativos, gram-positivos (bacilos/cocos) e gram-positivos filamentosos, respectivamente. Pela técnica de ERIC-PCR a porcentagem de bactérias gram-negativas, gram-positivas (bacilos/cocos) e gram-positivas filamentosas que mostraram $<2$ produtos de amplificação foram 40\%, $30 \%$ e $30 \%$, respectivamente. De um total de 41 bactérias quitinolíticas filamentosas, $30 \%(n=12)$ apresentaram <2 produtos de amplificação pelo BOX-PCR e $83 \%(n=34)$ apresentaram <2 
produtos de amplificação pelo ERIC-PCR. O número de bactérias quitinolíticas grampositivas (bacilos/cocos) que apresentaram $<2$ produtos de amplificação pela técnica de ERIC-PCR também foi alto, correspondendo a $59 \%$ do total de bactérias gram-positivas (bacilos/cocos) isoladas nos três locais de coleta de amostras.

\subsubsection{Canal de São Sebastião}

\section{$\underline{\text { Água do Mar }}$}

Pela técnica de BOX-PCR, foi verificada uma similaridade inicial de 8,6\% entre os perfis genômicos das 58 bactérias quitinolíticas isoladas de amostras de água do mar que apresentaram produtos de amplificação por essa técnica. Foram identificados dez agrupamentos (clusters) com similaridade $\geq 70 \%$. No entanto, nove agrupamentos eram formados por apenas dois isolados e apenas um era formado por três isolados. Em dois desses agrupamentos, verificamos que os isolados CH82 e CH34, gram-positivos (bacilo), apresentaram respectivamente, $88,9 \%$ e $80 \%$ de similaridade com os isolados gram-positivos filamentosos, $\mathrm{CH} 261$ e $\mathrm{CH} 32$. Em cinco dos dez agrupamentos com similaridade $\geq 70 \%$, os isolados quitinolíticos eram formados por bactérias isoladas em datas diferentes, porém no

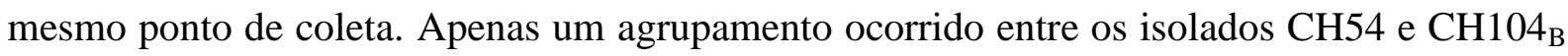
e que apresentou $90,9 \%$ de similaridade era formado por bactérias isoladas em datas e pontos de coleta distintos. Três agrupamentos que apresentaram 100\% de similaridade entre os seus isolados eram formados por bactérias quitinolíticas isoladas na mesma data e no mesmo ponto de coleta (Figura 30).

O dendrograma obtido pela técnica de ERIC-PCR apresentou uma similaridade inicial de $9 \%$ entre os isolados quitinolíticos e 07 agrupamentos com similaridade $\geq 70 \%$. Desses agrupamentos, dois eram compostos por três isolados e o restante dos agrupamentos era formado por dois isolados. Um desses agrupamentos era composto pelo isolado quitinolítico denominado CH177 e a cepa padrão 569 B (V. cholerae O1), com similaridade entre eles de $80 \%$. Foi verificado apenas um agrupamento composto por isolados coletados em datas diferentes e no mesmo ponto de coleta $\left(\mathrm{CH}^{2} 8_{\mathrm{T}}\right.$ e $\left.\mathrm{CH} 102_{\mathrm{B}}\right)$. Três agrupamentos que apresentaram $\geq 70 \%$ de similaridade entre os seus membros, eram formados por bactérias quitinolíticas isoladas em datas e pontos distintos. Foram identificados três agrupamentos compostos por bactérias quitinolíticas isoladas na mesma data e mesmo ponto de coleta de 
amostras, sendo que um desses agrupamentos era formado por três isolados, um deles $\left(\mathrm{CH}_{9} 8_{\mathrm{T}}\right)$ coletado em data diferente e no mesmo ponto de coleta dos outros dois $\left(\mathrm{CH} 102_{\mathrm{B}} \mathrm{e}\right.$ $\mathrm{CH}_{104}$ ) (Figura 31).

Comparando os isolados que apresentaram $\geq 70 \%$ de similaridade nas duas técnicas de rep-PCR, verificamos que somente o agrupamento composto pelas bactérias quitinolíticas CH256 e CH257 apresentou 100\% de similaridade entre si pela duas técnicas. Os isolados CH255 e CH252 apresentaram, entre si, 100\% de similaridade pela técnica de BOX-PCR e 88,9\% pela técnica de ERIC-PCR. Pela técnica de BOX-PCR, os isolados $\mathrm{CH} 98_{\mathrm{T}}$ e $\mathrm{CH} 102_{\mathrm{B}}$ apresentaram $80 \%$ de similaridade, enquanto que pela técnica de ERIC-PCR eles apresentaram $100 \%$ de similaridade entre si.

Pela técnica de BOX-PCR, analisando os agrupamentos com similaridade $\geq 60 \%$ e $<70 \%$, verificamos que cinco agrupamentos compostos por dois isolados cada um e um agrupamento contendo quatro isolados eram formados por bactérias gram-negativas e grampositivas. Esse tipo de agrupamento também pôde ser observado no dendrograma obtido pela técnica de ERIC-PCR, no qual os isolados CH11 (gram-negativo) e CH20 (gram-positivo) apresentaram 66,7\% de similaridade entre si. No entanto, esse tipo de agrupamento não foi observado nos agrupamentos que apresentaram $\geq 70 \%$ de similaridade. 


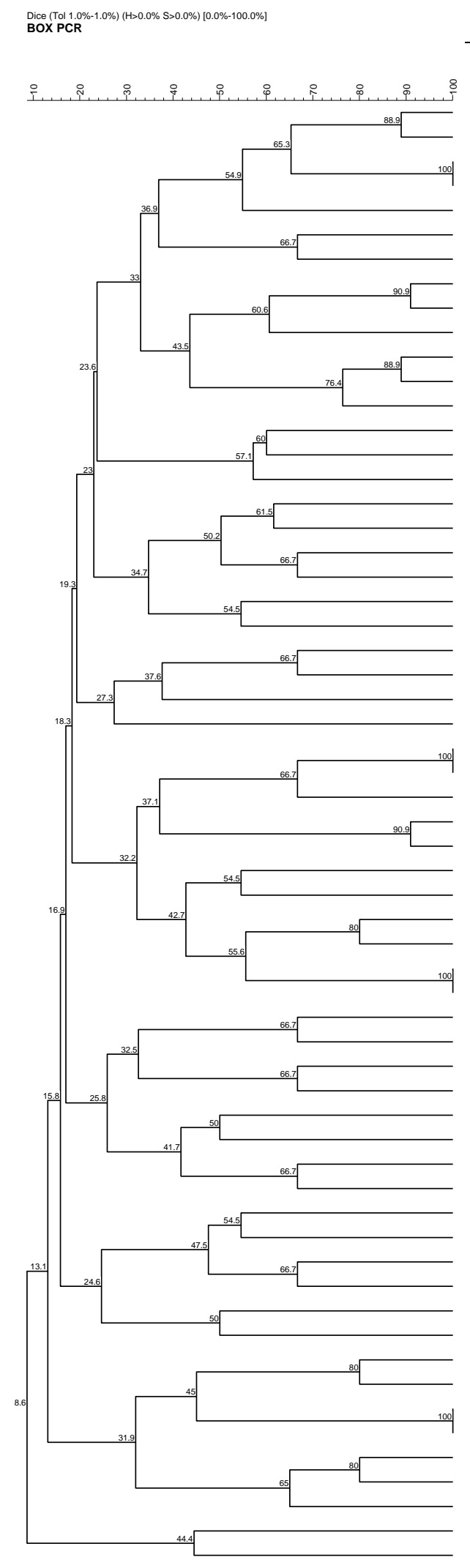

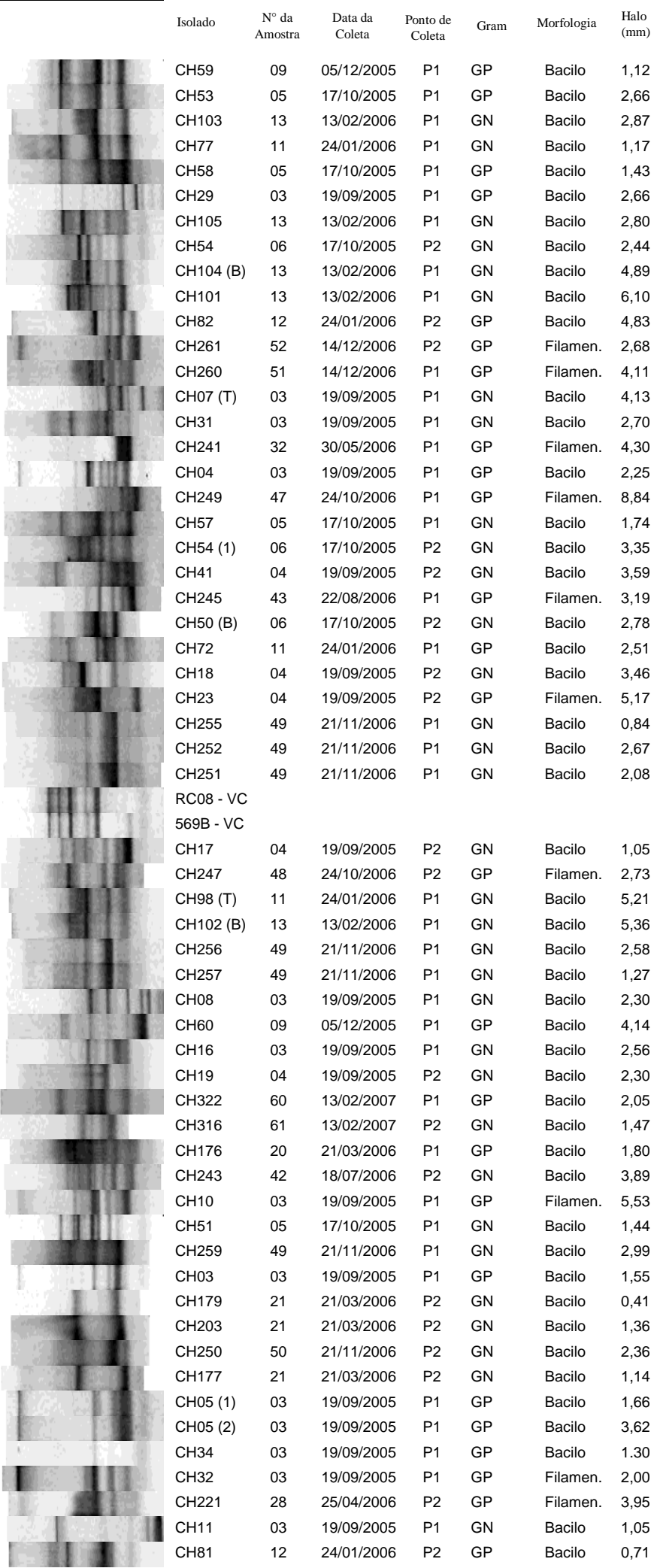

Figura 30 - Dendrograma construído com a técnica de BOX-PCR com bactérias quitinolíticas isoladas de amostras de água do mar do Canal de São Sebastião.

Legenda: GN - Gram-negativo; GP - Gram-positivo; Filamen. - Filamentoso; RC08-VC - V. cholerae $\mathrm{O} 1 ; 569 \mathrm{~B}-\mathrm{VC}$ - Vibrio cholerae 01. 


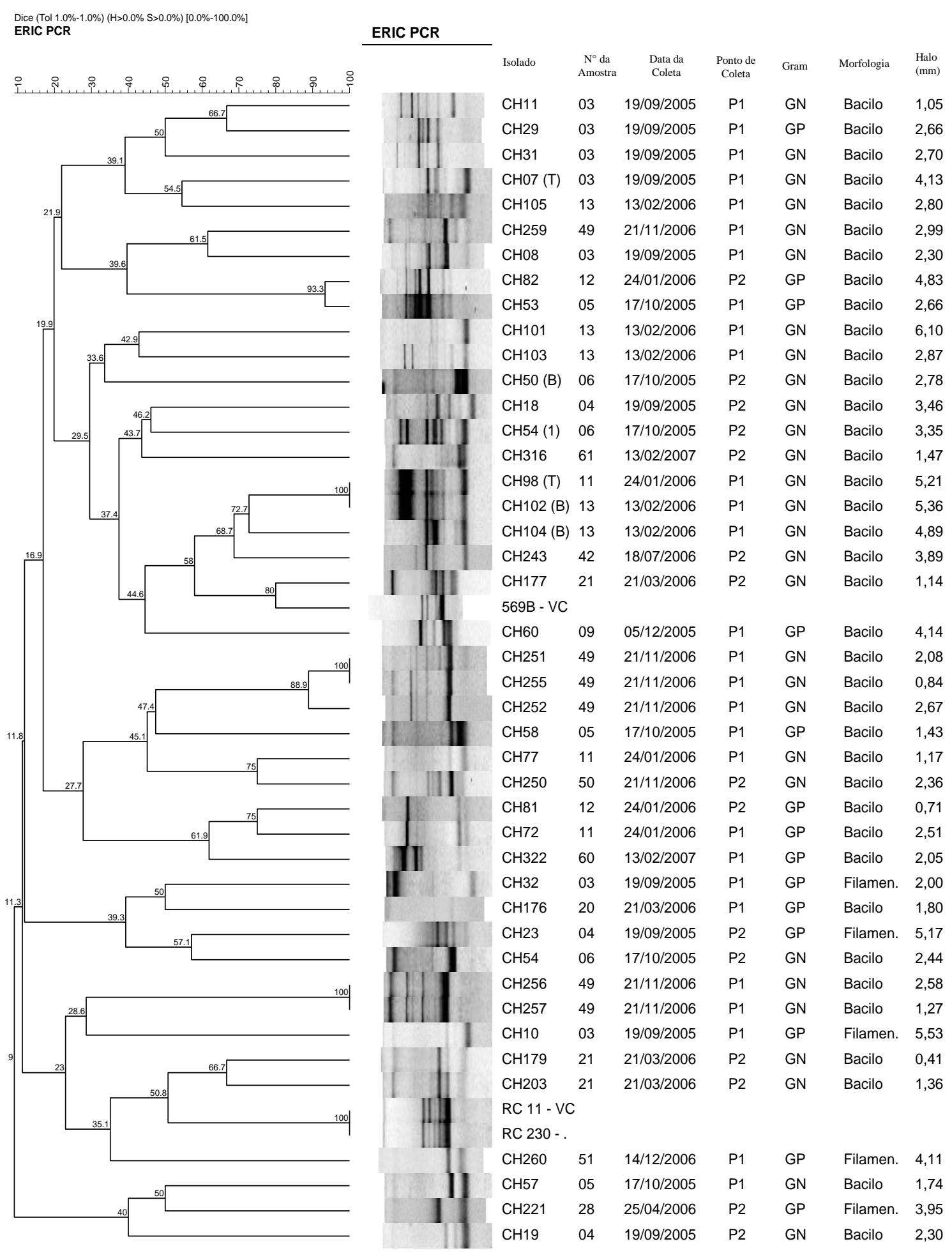

Figura 31 - Dendrograma construído com a técnica de ERIC-PCR com bactérias quitinolíticas isoladas de amostras de água do mar do Canal de São Sebastião.

Legenda - GN: Gram-negativo; GP: Gram-positivo; Filamen.: Filamentoso; 569B-VC: Vibrio cholerae 01; RC11-VC: V. cholerae O1; RC230-VC: V. cholerae O1. 


\section{Plâncton marinho}

As 73 bactérias quitinolíticas isoladas de amostras de plâncton apresentaram uma similaridade inicial de 8,7\% entre si, pela técnica de BOX-PCR e formaram 10 agrupamentos com similaridade $\geq 70 \%$. Dentre esses agrupamentos, oito eram compostos por somente dois isolados quitinolíticos, um era formado por cinco isolados e o outro agrupamento por seis isolados. Em seis agrupamentos formados por apenas dois isolados e que apresentaram $\geq 70 \%$, verificou-se que três deles eram formados por bactérias quitinolíticas isoladas em datas diferentes. Porém, no mesmo ponto de coleta, dois agrupamentos eram formados por isolados obtidos em pontos de coleta distintos, mas na mesma data e apenas um agrupamento era composto por bactérias quitinolíticas isoladas em datas e pontos diferentes $(\mathrm{CHZ140} 2 \mathrm{e}$ CHZ280). Analisando os dois maiores agrupamentos que apresentaram $\geq 70 \%$ de similaridade entre os seus membros, foi verificado que um deles era formado por bactérias isoladas no mesmo ponto de coleta (Ponto 2). No entanto, duas bactérias foram isoladas em 18/07/2006 e três bactérias em 22/08/2006. No outro agrupamento, todas as bactérias foram isoladas no Ponto 1, mas duas delas foram obtidas de amostras coletadas em 24/01/2006 e quatro em $23 / 01 / 2007$. Dentre os agrupamentos com $\geq 70 \%$ de similaridade, foram obtidos apenas dois agrupamentos, os quais eram formados por bactérias isoladas na mesma data e mesmo ponto de coleta (Figura 32).

A partir da análise dos perfis obtidos pela técnica de ERIC-PCR, foi verificado que a similaridade inicial entre as 44 bactérias quitinolíticas que apresentaram $\geq 2$ produtos de amplificação foi de $5,1 \%$ e três agrupamentos com similaridade $\geq 70 \%$ puderam ser distinguidos. Dois desses agrupamentos eram compostos por duas bactérias quitinolíticas cada um, as quais foram isoladas em datas e pontos de coleta distintos. O terceiro agrupamento era formado por três bactérias isoladas em 22/08/2006 no ponto 2 (Figura 33).

Apenas os isolados CHZ127, CHZ127 e $_{1}$ CHZ127 2 apresentaram $\geq 70 \%$ de similaridade entre si, tanto pela técnica de BOX-PCR quanto pela técnica de ERIC-PCR. Analisando os agrupamentos que apresentaram similaridade $\geq 60 \%$ e $<70 \%$ pela técnica de BOX-PCR, foi verificado a ocorrência de quatro agrupamentos formados entre bactérias gram-positivas e gram-negativas, sendo que dois deles eram compostos por bactérias quitinolíticas gram-negativas e gram-positivas filamentosas. Pela técnica de ERIC-PCR, esse tipo de agrupamento não foi observado no dendrograma e em ambas as técnicas não foram 
observados agrupamentos com similaridade $\geq 70 \%$ ocorrido entre bactérias quitinolíticas gram-positivas e gram-negativas. 

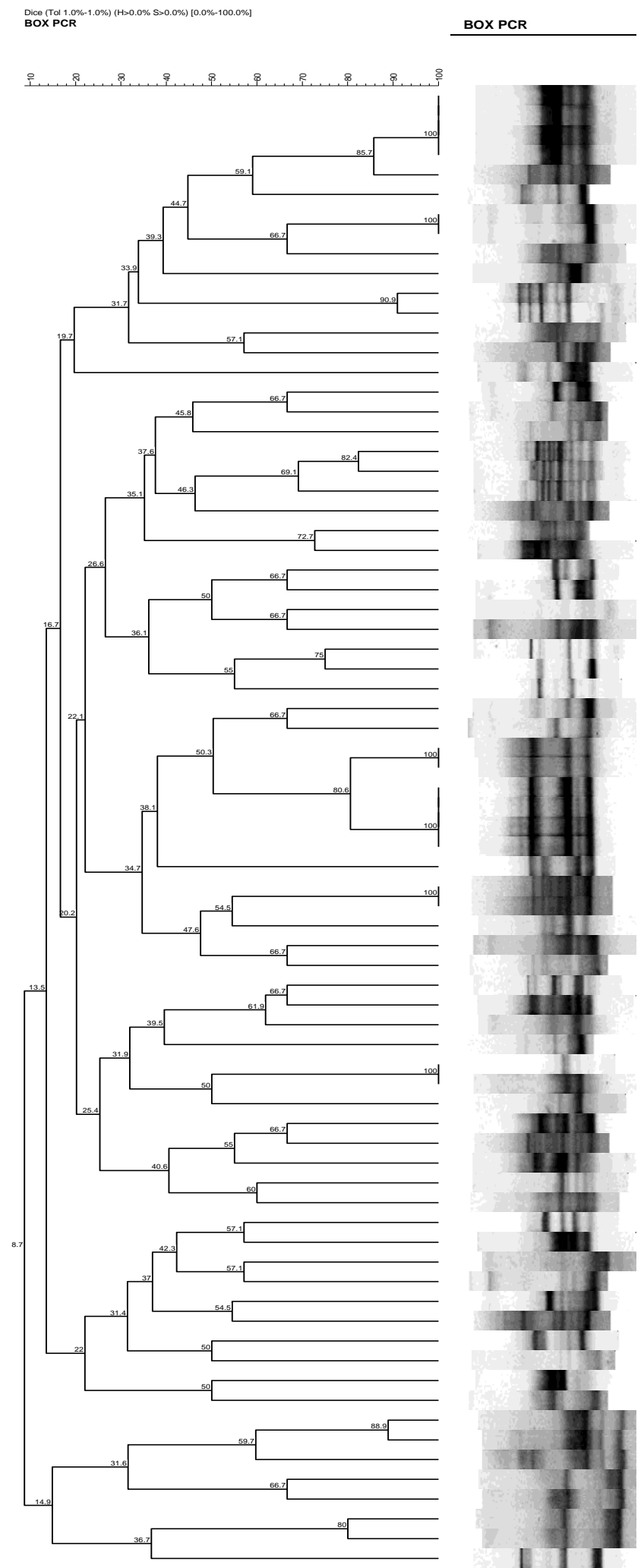

\begin{tabular}{|c|c|}
\hline Isolado & $\begin{array}{l}\mathrm{N}^{\circ} \mathrm{da} \\
\text { Amost }\end{array}$ \\
\hline $\mathrm{CHZ127}$ (17) & 42 \\
\hline $\mathrm{CHZ127}$ & 44 \\
\hline $\mathrm{CHZ127}$ (1) & 44 \\
\hline $\mathrm{CHZ127}$ (2) & 44 \\
\hline $\mathrm{CHZ121}$ & 42 \\
\hline $\mathrm{CHZ117}$ & 41 \\
\hline $\mathrm{CHZ136}$ & 47 \\
\hline $\mathrm{CHZ139}$ (B) & 47 \\
\hline $\mathrm{CHZ108}$ & 42 \\
\hline $\mathrm{CHZ137}$ & 47 \\
\hline RC08-VC & \\
\hline $569 \mathrm{~B}-\mathrm{VC}$ & \\
\hline $\mathrm{CHZ} 122$ & 42 \\
\hline $\mathrm{CHZ142}$ & 48 \\
\hline CHZ233 (B) & 60 \\
\hline CHZ220 & 54 \\
\hline CHZ276 & 67 \\
\hline CHZ274 & 67 \\
\hline $\mathrm{CHZ100}$ (1) & 39 \\
\hline CHZ115 & 41 \\
\hline $\mathrm{CHZ114}$ & 41 \\
\hline $\mathrm{CHZ210}(\mathrm{X})$ & 53 \\
\hline CHZ118 & 41 \\
\hline CHZ234 & 60 \\
\hline $\mathrm{CHZ154}$ & 50 \\
\hline $\mathrm{CHZ156}$ & 50 \\
\hline $\mathrm{CHZ131}$ & 45 \\
\hline CHZ277 & 67 \\
\hline $\mathrm{CHZ116}$ & 41 \\
\hline $\mathrm{CHZ150}$ & 49 \\
\hline $\mathrm{CHZ155}$ & 50 \\
\hline $\mathrm{CHZ138}$ & 47 \\
\hline CHZ289 & 68 \\
\hline $\mathrm{CHZ60}$ & 11 \\
\hline CHZ62 & 11 \\
\hline CHZ166 & 53 \\
\hline CHZ167 & 53 \\
\hline CHZ211 (X) & 53 \\
\hline CHZ212 & 53 \\
\hline CHZ146 (2) & 48 \\
\hline $\mathrm{CHZ46}$ & 33 \\
\hline $\mathrm{CHZ} 47$ & 33 \\
\hline $\mathrm{CHZ75}$ (1) & 12 \\
\hline CHZ226 & 61 \\
\hline CHZ272 & 67 \\
\hline $\mathrm{CHZ113}$ & 41 \\
\hline $\mathrm{CHZ254}$ & 60 \\
\hline $\mathrm{CHZ80}$ (1) & 11 \\
\hline $\mathrm{CHZ109}(\mathrm{T})$ & 42 \\
\hline $\mathrm{CHZ140} \mathrm{(2)}$ & 47 \\
\hline CHZ280 & 68 \\
\hline $\mathrm{CHZ110}$ & 42 \\
\hline $\mathrm{CHZ165}$ & 51 \\
\hline $\mathrm{CHZ143}$ & 48 \\
\hline $\mathrm{CHZ139}(\mathrm{T})$ & 47 \\
\hline CHZ45 & 32 \\
\hline CHZ246 & 61 \\
\hline $\mathrm{CHZ152}$ & 50 \\
\hline CHZ236 & 60 \\
\hline $\mathrm{CHZ75}$ (2) & 12 \\
\hline CHZ286 & 68 \\
\hline $\mathrm{CHZ171}$ & 54 \\
\hline $\mathrm{CHZ111}$ & 42 \\
\hline $\mathrm{CHZ149}$ & 49 \\
\hline CHZ245 & 61 \\
\hline $\mathrm{CHZ162}$ & 51 \\
\hline CHZ271 & 67 \\
\hline $\mathrm{CHZ79}$ & 11 \\
\hline CHZ84 & 12 \\
\hline $\mathrm{CHZ76}$ & 12 \\
\hline CHZ85 & 11 \\
\hline CHZ87 & 13 \\
\hline CHZ67 & 11 \\
\hline $\mathrm{CHZ77}$ (2) & 12 \\
\hline $\mathrm{CHZ107}$ & 40 \\
\hline
\end{tabular}

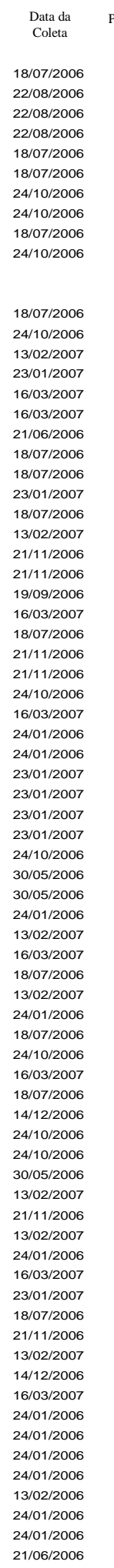

$\begin{gathered}\text { Ponto de } \\ \text { Coleta }\end{gathered}$
P2
P2
P2
P2
P2
P1
P1
P1
P2
P1

Gram Morfologia $\underset{(\mathrm{mm})}{\mathrm{Hal}}$

GN Bacilo 2,22

GN Bacilo 1,69

GN Bacilo $\quad 2,03$

GN Bacilo 4,21

GN Bacilo 2,42

GP Bacilo 2,92

GN Bacilo 1,89

GN Bacilo 2,65

GN Bacilo 3,03

GP Filamen. 2,57

GN Bacilo 1,53

GP Filamen. 1,31

$\begin{array}{lll}\text { GP } & \text { Bacilo } & 4,68 \\ \text { GN } & \text { Bacilo } & 0,5 \text { * }\end{array}$

GN Bacilo 2,64

GN Coco Bacilo 232

GN Bacilo 2,32

GN Bacilo 2,66

GP Bacilo 2,84

$\begin{array}{lll}\text { GP } & \text { Filamen. } & 0,88 \\ \text { GP } & \text { Bacilo } & 1,94\end{array}$

GP Bacilo 1,63

GP Bacilo 0,82

GP Bacilo 1,69

GN Coco Bacilo 2,54

$\begin{array}{lll}\text { GN } & \text { Bacilo } & 2,57 \\ \text { GN } & \text { Bacilo } & 1,20\end{array}$

GN Coco Bacilo $5,7 . \star$

GN Coco Bacilo 2,30

GN Coco Bacilo 2,61

GN Bacilo $\quad 0,89$

GN Coco Bacilo 1,55

GN Coco Bacilo 4,96

$\begin{array}{lll}\text { GN } & \text { Bacilo } & 1,73 \\ \text { GN } & \text { Bacilo } & 2,55\end{array}$

GN Coco Bacilo 3,88

GN Bacilo 2,27

GP Filamen 1,43

$\begin{array}{lll}\text { GN } & \text { Bacilo } & 1,43 \\ \text { GN } & , 67\end{array}$

$\begin{array}{lll}\text { GN } & \text { Bacilo } & 2,67 \\ \text { GN } & \text { Bacilo } & 2,97\end{array}$

GP Bacilo 1,77

GN Bacilo $\quad 1,11$

GP Filamen $\quad 8,41$

GP Filamen 2,54

GN Bacilo 1,47

$\begin{array}{lll}\text { GN } & \text { Bacilo } & 1,47 \\ \text { GN } & \text { Bacilo } & 3,85\end{array}$

$\begin{array}{lll}\text { GN Bacilo } & 3,85 \\ \text { GN } & \text { Bacilo } & 3,08\end{array}$

GN Bacilo $\quad 3,04$

GN Bacilo $\quad 2,53$

GP $\quad 1,50$

GP 1,56

$\begin{array}{lll}\text { GP } & \text { Filamen. } & 1,36 \\ \text { GN } & \text { Bacilo } & 1,07\end{array}$

$\begin{array}{lll}\text { GN } & \text { Bacilo } & 1,07 \\ \text { GP } & \text { Bacilo } & 1,87\end{array}$

GP Filamen. 1,54

GN Bacilo 2,44

GN Bacilo 0,54

GN Bacilo 0,81

GN Bacilo 1,17

GP Filamen. 1,43

GN Coco Bacilo $\quad 3,30$

GN Bacilo $\quad 2,51$

GN Bacilo 0,73

GN Bacilo 0,98

GN Bacilo 1,66

GN Bacilo $\quad \begin{array}{ll}1,66 \\ \text { GN }\end{array}$

Figura 32 - Dendrograma construído com a técnica de BOX-PCR com bactérias quitinolíticas isoladas de amostras de plâncton do mar do Canal de São Sebastião.

Legenda: GN - Gram-negativo; GP - Gram-positivo; Filamen. - Filamentoso; RC08-VC - V. cholerae $\mathrm{O} 1 ;$ 569B-VC - Vibrio cholerae 01.

Nota: A medida do halo de hidrólise de quitina dos isolados CHZ100 (1) e CHZ60 foi realizada com 168 h de incubação. 


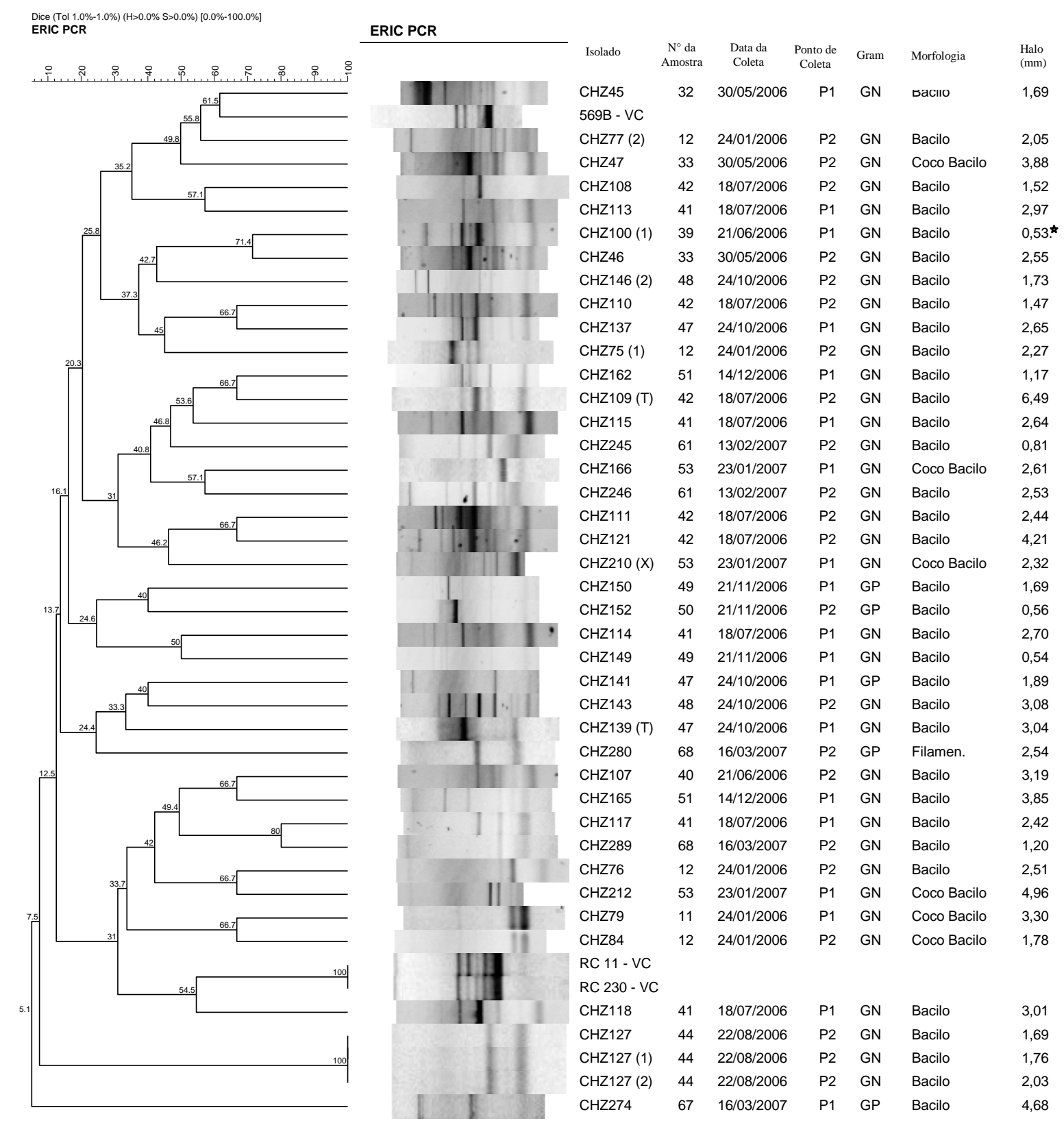

Figura 33 - Dendrograma construído com a técnica de ERIC-PCR com bactérias quitinolíticas isoladas de amostras de plâncton do Canal de São Sebastião.

Legenda - GN: Gram-negativo; GP: Gram-positivo; Filamen.: Filamentoso; 569B-VC: Vibrio cholerae 01; RC11-VC: V. cholerae O1; RC230-VC: V. cholerae O1.

Nota: A medida do halo de hidrólise de quitina do isolado CHZ100 (1) foi realizada com 168 h de incubação. 


\subsubsection{Ubatuba}

\section{$\underline{\text { Água do Mar }}$}

Foram submetidas às técnicas de BOX-PCR e ERIC-PCR quatro bactérias quitinolíticas (01 bactéria gram-negativa e 03 bactérias gram-positivas filamentosas) e dessas, duas não apresentaram produtos de amplificação pela técnica de BOX-PCR e três pela técnica de ERIC-PCR. Diante disso, não foi possível construir um dendrograma com os isolados quitinolíticos de amostras de água do mar de Ubatuba.

\section{Plâncton Marinho}

O dendrograma obtido com a técnica de BOX-PCR mostrou uma similaridade inicial de 6,7\% entre os 32 isolados quitinolíticos analisados e apenas dois agrupamentos com similaridade $\geq 70 \%$. Um dos agrupamentos era formado por três isolados e o outro por nove isolados, porém os doze isolados foram obtidos no mesmo ponto de coleta (Ponto 1) em 16/03/2007 (Figura 34).

Pela técnica de ERIC-PCR, a similaridade inicial entre as 13 bactérias quitinolíticas presentes no dendrograma foi de $6,2 \%$ e dois agrupamentos apresentaram similaridade $\geq 70 \%$. Em um desses agrupamentos estavam presentes dois isolados e em outro quatro isolados quitinolíticos. Todos esses isolados também foram obtidos na mesma data e ponto de coleta (16/03/2007 - Ponto 1) (Figura 35).

Comparando os isolados que apresentaram $\geq 70 \%$ de similaridade nas duas técnicas de rep-PCR, verificamos que as bactérias quitinolíticas CHZ295 e CHZ293 apresentaram 100\% de similaridade entre si pelas duas técnicas. Os isolados CHZ298 e CHZ294 tiveram uma similaridade entre si de $100 \%$ pela técnica de BOX-PCR e 90,9\% pela técnica de ERIC-PCR. O isolado CHZ299 apresentou 100\% de similaridade com os isolados CHZ295 e CHZ293 pela técnica de BOX-PCR e 83,3\% com os mesmos isolados pela técnica de ERIC-PCR. A similaridade do isolado CHZ297 com os isolados CHZ295, CHZ293 e CHZ299 pela técnica de BOX-PCR foi de $100 \%$ e pela técnica de ERIC-PCR foi de $80 \%$. Não foi observado nenhum agrupamento entre bactérias quitinolíticas gram-positivas e gram-negativas com similaridade $\geq 60 \%$. 


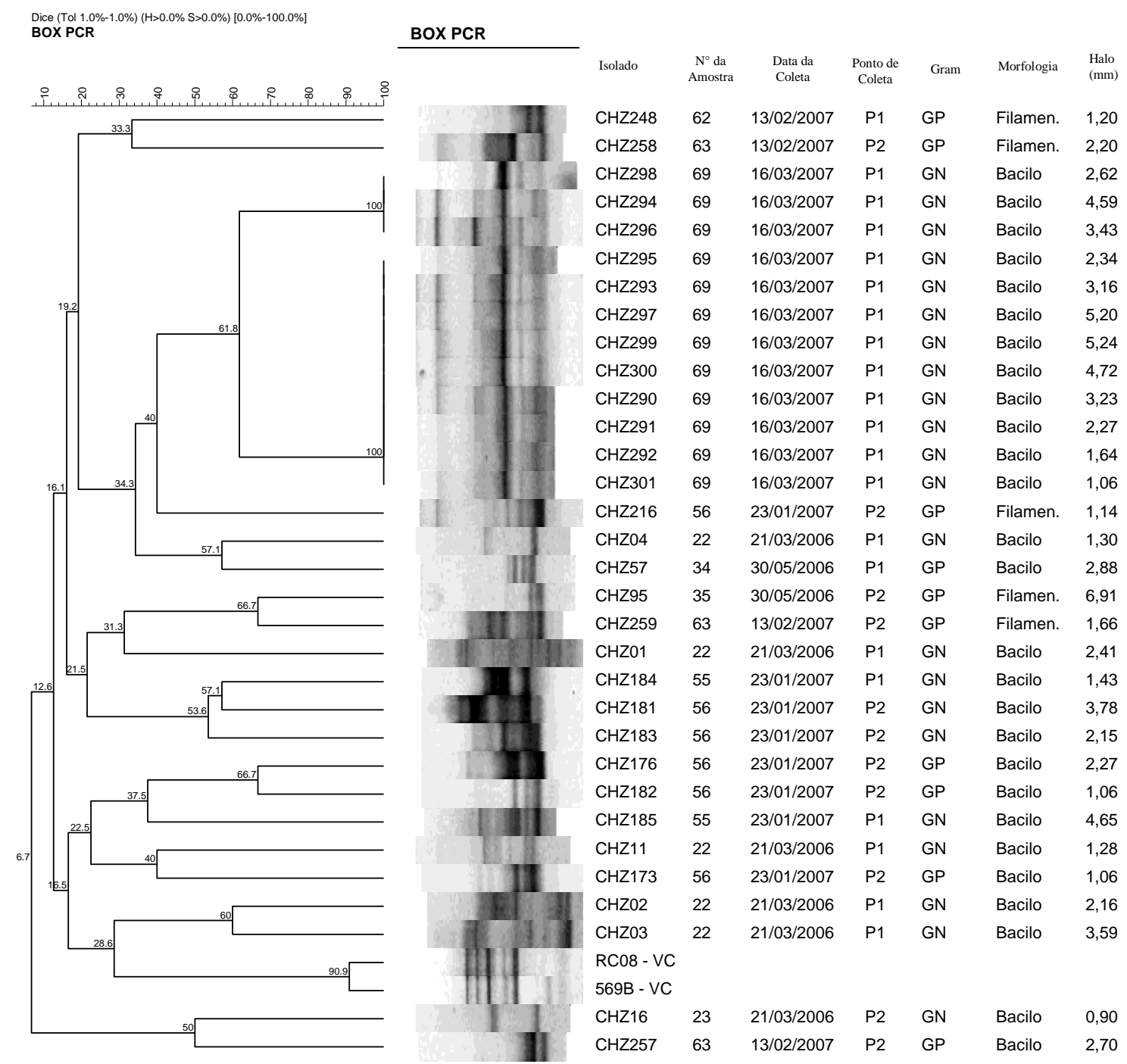

Figura 34 - Dendrograma construído com a técnica de BOX-PCR com bactérias quitinolíticas isoladas de amostras de plâncton de Ubatuba.

Legenda: GN - Gram-negativo; GP - Gram-positivo; Filamen. - Filamentoso; RC08-VC - V. cholerae $\mathrm{O} 1 ; 569 \mathrm{~B}-\mathrm{VC}$ - Vibrio cholerae 01 . 


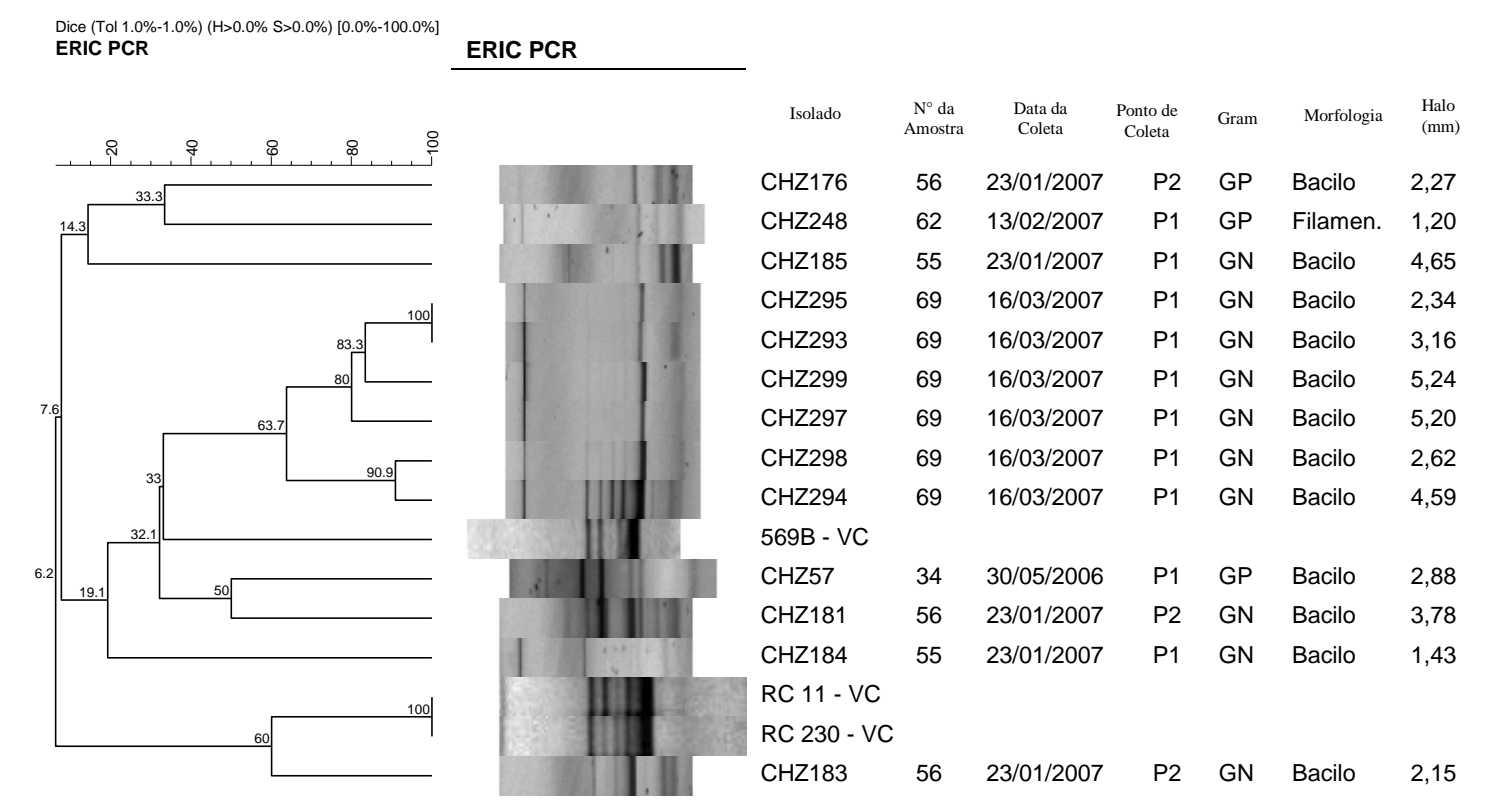

Figura 35 - Dendrograma construído com a técnica de ERIC-PCR com bactérias quitinolíticas isoladas de amostras de plâncton de Ubatuba.

Legenda: GN - Gram-negativo; GP - Gram-positivo; Filamen. - Filamentoso; RC08-VC - V. cholerae $\mathrm{O} 1 ; 569 \mathrm{~B}-\mathrm{VC}$ - Vibrio cholerae 01.

\subsubsection{Baixada Santista}

\section{$\underline{\text { Água do Mar }}$}

Foi verificado que a similaridade inicial entre as 113 bactérias quitinolíticas presentes no dendrograma gerado pela técnica de BOX-PCR foi de 12,3\% e puderam ser distinguidos 24 agrupamentos com similaridade $\geq 70 \%$. Dentre esses agrupamentos, o maior continha cinco isolados e a maioria, (15 agrupamentos), continha apenas dois isolados em cada um. Os agrupamentos que apresentaram similaridade $\geq 70 \%$ eram formados por bactérias isoladas em datas e pontos de coleta distintos (08 agrupamentos), em datas de coletas diferentes e mesmos pontos de coleta (08 agrupamentos), na mesma data, mas pontos de coletas diferentes (03 agrupamentos) e finalmente 07 agrupamentos eram formados por bactérias quitinolíticas isoladas na mesma data e no mesmo ponto de coleta (Figura 36).

A similaridade inicial observada entre os 106 isolados quitinolíticos que apresentaram $\geq 2$ produtos de amplificação pela técnica de ERIC-PCR foi de 5,4\% e foram obtidos um total de 22 agrupamentos com similaridade $\geq 70 \%$. Analisando os 22 agrupamentos, foi verificado que 09, 06, 03 e 04 agrupamentos eram compostos por 02, 03, 05 e 04 isolados quitinolíticos, 
respectivamente. A maioria desses agrupamentos (10 agrupamentos) continha bactérias quitinolíticas isoladas em datas e pontos de coletas diferentes e os outros agrupamentos eram formados por bactérias isoladas na mesma data, mas em pontos de coletas diferentes (03 agrupamentos), em datas de coleta de amostras distintas, mas no mesmo ponto de coleta (04 agrupamentos) e 05 agrupamentos eram compostos por bactérias isoladas na mesma data e no mesmo ponto de coleta (Figura 37).

A tabela 11 mostra os isolados quitinolíticos que apresentaram $\geq 70 \%$ de similaridade por ambas as técnicas rep-PCR.

Tabela 11 - Valores de similaridades apresentadas nas técnicas de ERIC-PCR e BOX-PCR.

\begin{tabular}{lcc}
\hline \multicolumn{1}{c}{ Isolados Quitinolíticos } & \multicolumn{2}{c}{ rep-PCR } \\
\cline { 2 - 3 } & BOX-PCR & ERIC-PCR \\
\hline $\mathrm{CH} 150_{\mathrm{B}} / \mathrm{CH} 151$ & $100 \%$ & $100 \%$ \\
$\mathrm{CH} 362_{\mathrm{B}} / \mathrm{CH} 362_{\mathrm{T}}$ & $100 \%$ & $88.9 \%$ \\
$\mathrm{CH} 362_{\mathrm{B}} / \mathrm{CH} 362_{\mathrm{T}} / \mathrm{CH} 341$ & $100 \%$ & $100 \%$ \\
$\mathrm{CH} 274_{\mathrm{B}} / \mathrm{CH} 274_{\mathrm{T}}$ & $100 \%$ & $100 \%$ \\
$\mathrm{CH} 330_{\mathrm{B}} / \mathrm{CH} 330_{\mathrm{T}}$ & $100 \%$ & $90.5 \%$ \\
$\mathrm{CH} 330_{\mathrm{B}} / \mathrm{CH} 330_{\mathrm{T}} / \mathrm{CH} 332$ & $80 \%$ & $90.9 \%$ \\
$\mathrm{CH} 286$ / CH288 & $100 \%$ & $100 \%$ \\
$\mathrm{CH} 374 / \mathrm{CH} 375$ & $100 \%$ & \\
\hline
\end{tabular}

Analisando os agrupamentos que apresentaram similaridade $\geq 60 \%$ e $<70 \%$ pela técnica de BOX-PCR, foi verificada a ocorrência de quatro agrupamentos formados entre bactérias gram-positivas e gram-negativas, sendo que um deles era composto por uma bactéria quitinolítica gram-negativa e uma gram-positiva filamentosa $\left(\mathrm{CH} 298_{\mathrm{T}}\right.$ e $\left.\mathrm{CH} 300\right)$. Pela técnica de ERIC-PCR, quatro agrupamentos desse tipo também foram observados e um deles também era formado por uma bactéria quitinolítica gram-negativa e uma gram-positiva filamentosa $\left(\mathrm{CH} 346_{\mathrm{T}}\right.$ e $\left.\mathrm{CH} 300\right)$. 


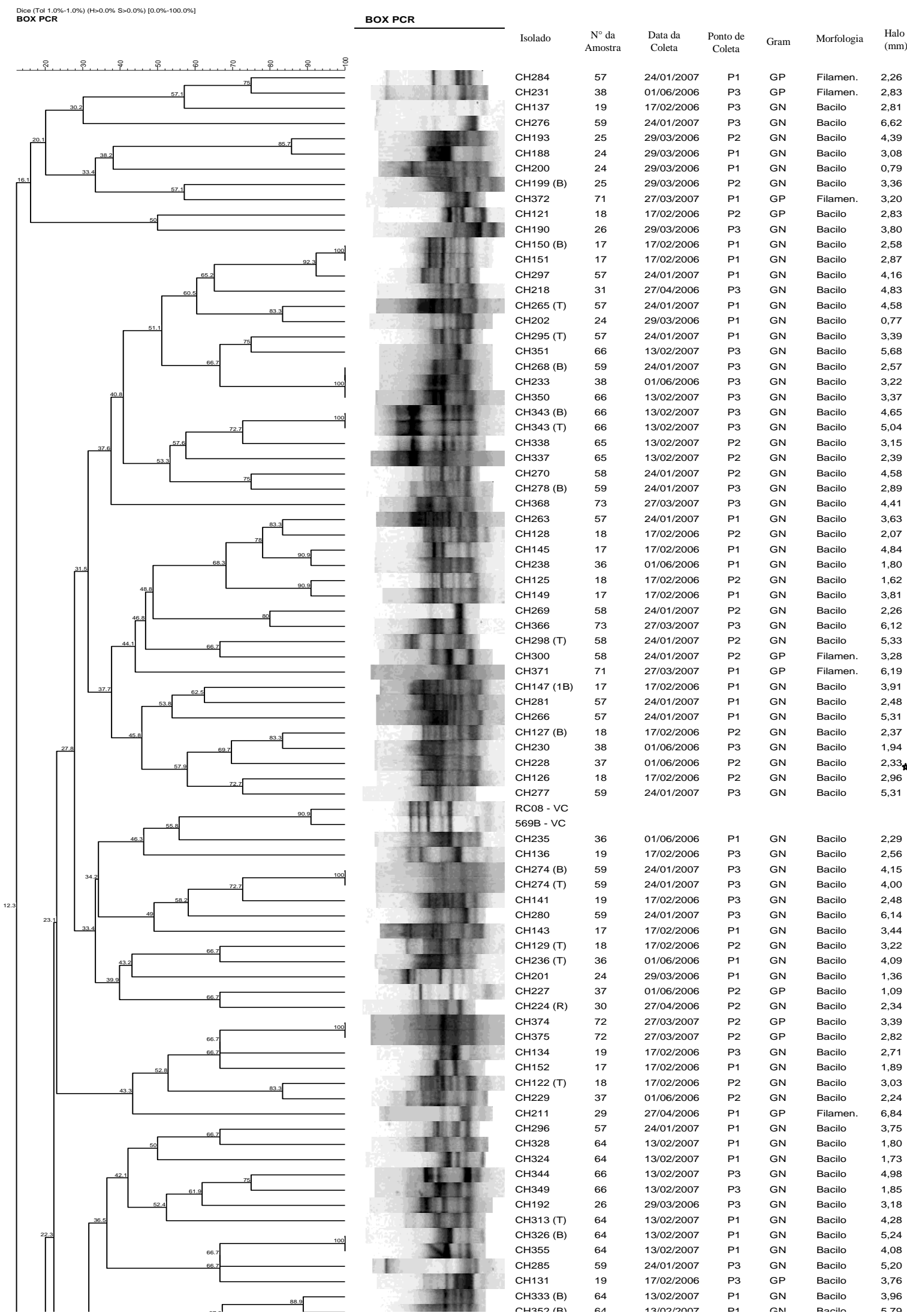

Figura 36 - Dendrograma construído com a técnica de BOX-PCR com bactérias quitinolíticas isoladas de amostras de água da Baixada Santista.

Legenda: GN - Gram-negativo; GP - Gram-positivo; Filamen. - Filamentoso; RC08-VC - V. cholerae $\mathrm{O1}$; 569B-VC - Vibrio cholerae 01. 

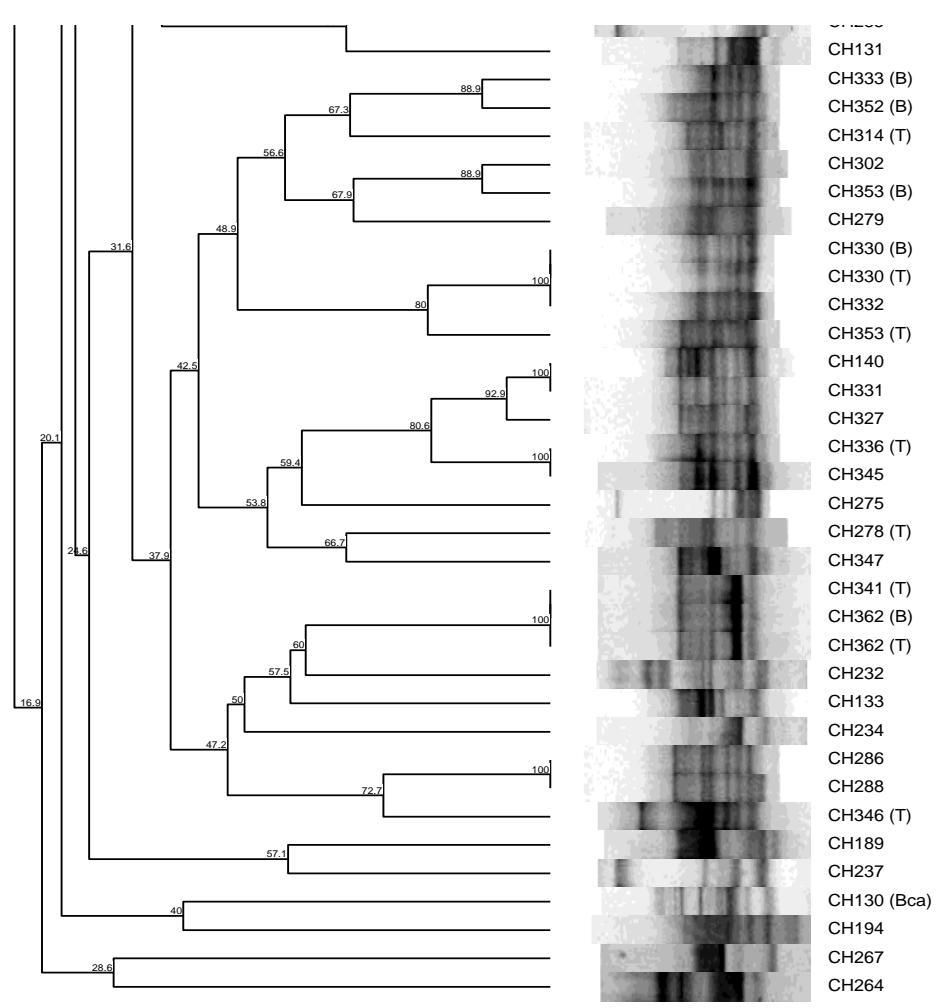

$\begin{array}{lllll}1 \ldots \ldots & \ldots & \ldots . & \text { - } \ldots \ldots \ldots & \\ 17 / 02 / 2006 & \text { P3 } & \text { GP } & \text { Bacilo } & 3,76 \\ 13 / 02 / 2007 & \text { P1 } & \text { GN } & \text { Bacilo } & 3,96 \\ 13 / 02 / 2007 & \text { P1 } & \text { GN } & \text { Bacilo } & 5,79 \\ 13 / 02 / 2007 & \text { P1 } & \text { GN } & \text { Bacilo } & 5,80 \\ 24 / 01 / 2007 & \text { P2 } & \text { GN } & \text { Bacilo } & 5,97 \\ 13 / 02 / 2007 & \text { P1 } & \text { GN } & \text { Bacilo } & 5,55 \\ 24 / 01 / 2007 & \text { P3 } & \text { GN } & \text { Bacilo } & 1,98 \\ 13 / 02 / 2007 & \text { P1 } & \text { GN } & \text { Bacilo } & 5,14 \\ 13 / 02 / 2007 & \text { P1 } & \text { GN } & \text { Bacilo } & 5,76 \\ 13 / 02 / 2007 & \text { P1 } & \text { GN } & \text { Bacilo } & 4,19 \\ 13 / 02 / 2007 & \text { P1 } & \text { GN } & \text { Bacilo } & 4,26 \\ 17 / 02 / 2006 & \text { P3 } & \text { GN } & \text { Bacilo } & 2,31 \\ 13 / 02 / 2007 & \text { P1 } & \text { GN } & \text { Bacilo } & 5,15 \\ 13 / 02 / 2007 & \text { P1 } & \text { GN } & \text { Bacilo } & 2,94 \\ 13 / 02 / 2007 & \text { P2 } & \text { GN } & \text { Bacilo } & 2,33 \\ 13 / 02 / 2007 & \text { P3 } & \text { GN } & \text { Bacilo } & 4,69 \\ 24 / 01 / 2007 & \text { P3 } & \text { GP } & \text { Bacilo } & 2,02 \\ 24 / 01 / 2007 & \text { P3 } & \text { GN } & \text { Bacilo } & 3,38 \\ 13 / 02 / 2007 & \text { P3 } & \text { GN } & \text { Bacilo } & 4,64 \\ 13 / 02 / 2007 & \text { P2 } & \text { GN } & \text { Bacilo } & 3,58 \\ 13 / 02 / 2007 & \text { P2 } & \text { GN } & \text { Bacilo } & 5,13 \\ 13 / 02 / 2007 & \text { P2 } & \text { GN } & \text { Bacilo } & 4,45 \\ 01 / 06 / 2006 & \text { P3 } & \text { GN } & \text { Bacilo } & 6,04 \\ 17 / 02 / 2006 & \text { P3 } & \text { GN } & \text { Bacilo } & 4,27 \\ 01 / 06 / 2006 & \text { P3 } & \text { GN } & \text { Bacilo } & 3,80 \\ 24 / 01 / 2007 & \text { P3 } & \text { GN } & \text { Bacilo } & 6,91 \\ 24 / 01 / 2007 & \text { P3 } & \text { GN } & \text { Bacilo } & 5,45 \\ 13 / 02 / 2007 & \text { P3 } & \text { GN } & \text { Bacilo } & 4,68 \\ 29 / 03 / 2006 & \text { P1 } & \text { GN } & \text { Bacilo } & 2,89 \\ 01 / 06 / 2006 & \text { P1 } & \text { GN } & \text { Bacilo } & 3,37 \\ 17 / 02 / 2006 & \text { P2 } & \text { GN } & \text { Bacilo } & 1,64 \\ 29 / 03 / 2006 & \text { P2 } & \text { GN } & \text { Bacilo } & 1,85 \\ 24 / 01 / 2007 & \text { P1 } & \text { GP } & \text { Bacilo } & 6,72 \\ 24 / 01 / 2007 & \text { P1 } & \text { GN } & \text { Bacilo } & 3,27\end{array}$

Figura 36 - Dendrograma construído com a técnica de BOX-PCR com bactérias quitinolíticas isoladas de amostras de água da Baixada Santista.

Legenda: GN - Gram-negativo; GP - Gram-positivo; Filamen. - Filamentoso; RC08-VC - V. cholerae $\mathrm{O} 1 ; 569 \mathrm{~B}-\mathrm{VC}$ - Vibrio cholerae 01.

Nota: A medida do halo de hidrólise de quitina do isolado $\mathrm{CH} 228$ foi realizada com $168 \mathrm{~h}$ de incubação. 


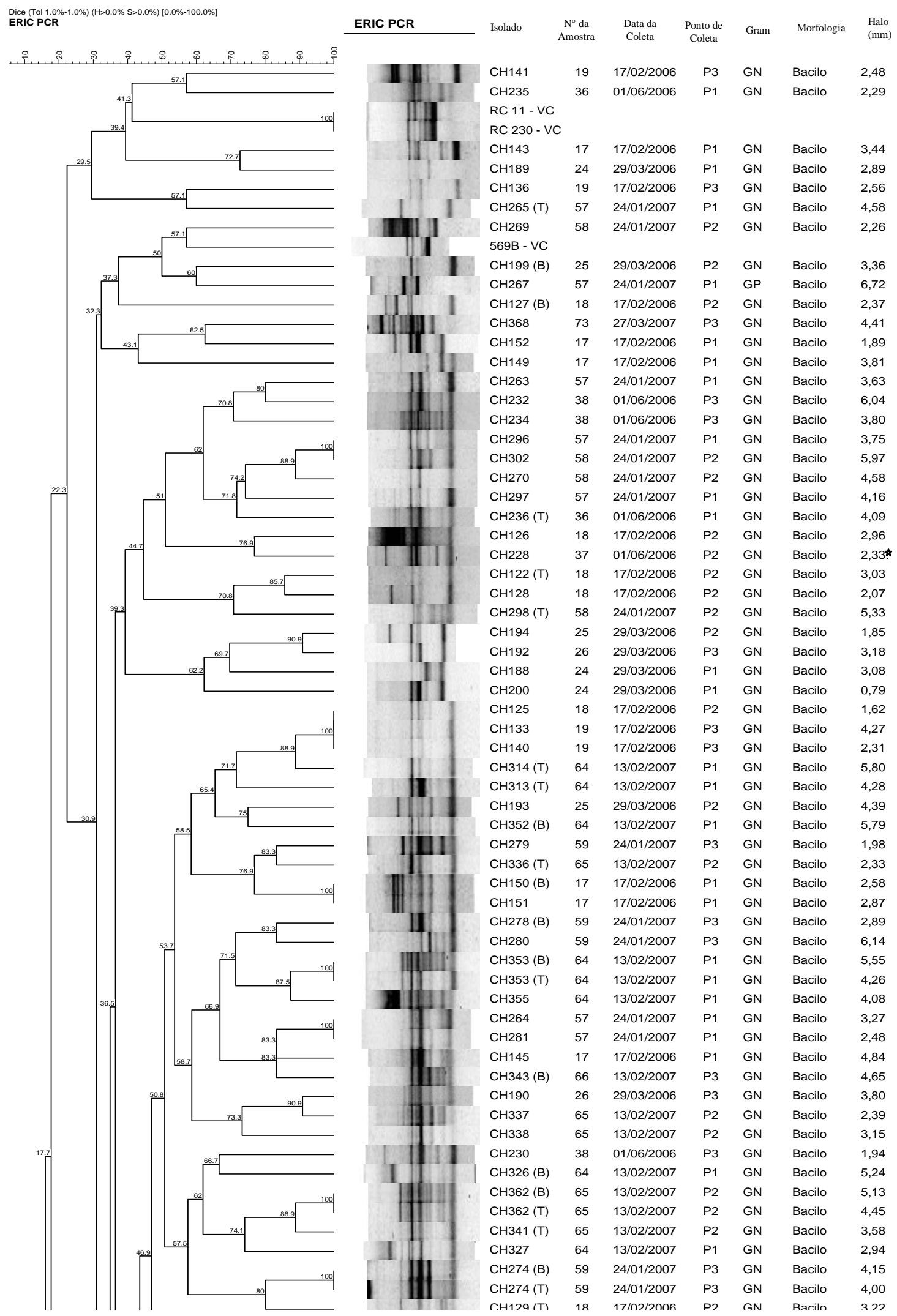

Figura 37 - Dendrograma construído com a técnica de ERIC-PCR com bactérias quitinolíticas isoladas de amostras de água da Baixada Santista.

Legenda: GN - Gram-negativo; GP - Gram-positivo; Filamen. - Filamentoso; RC08-VC - V. cholerae $\mathrm{O} 1 ; 569 \mathrm{~B}-\mathrm{VC}$ - Vibrio cholerae 01.

(continua) 

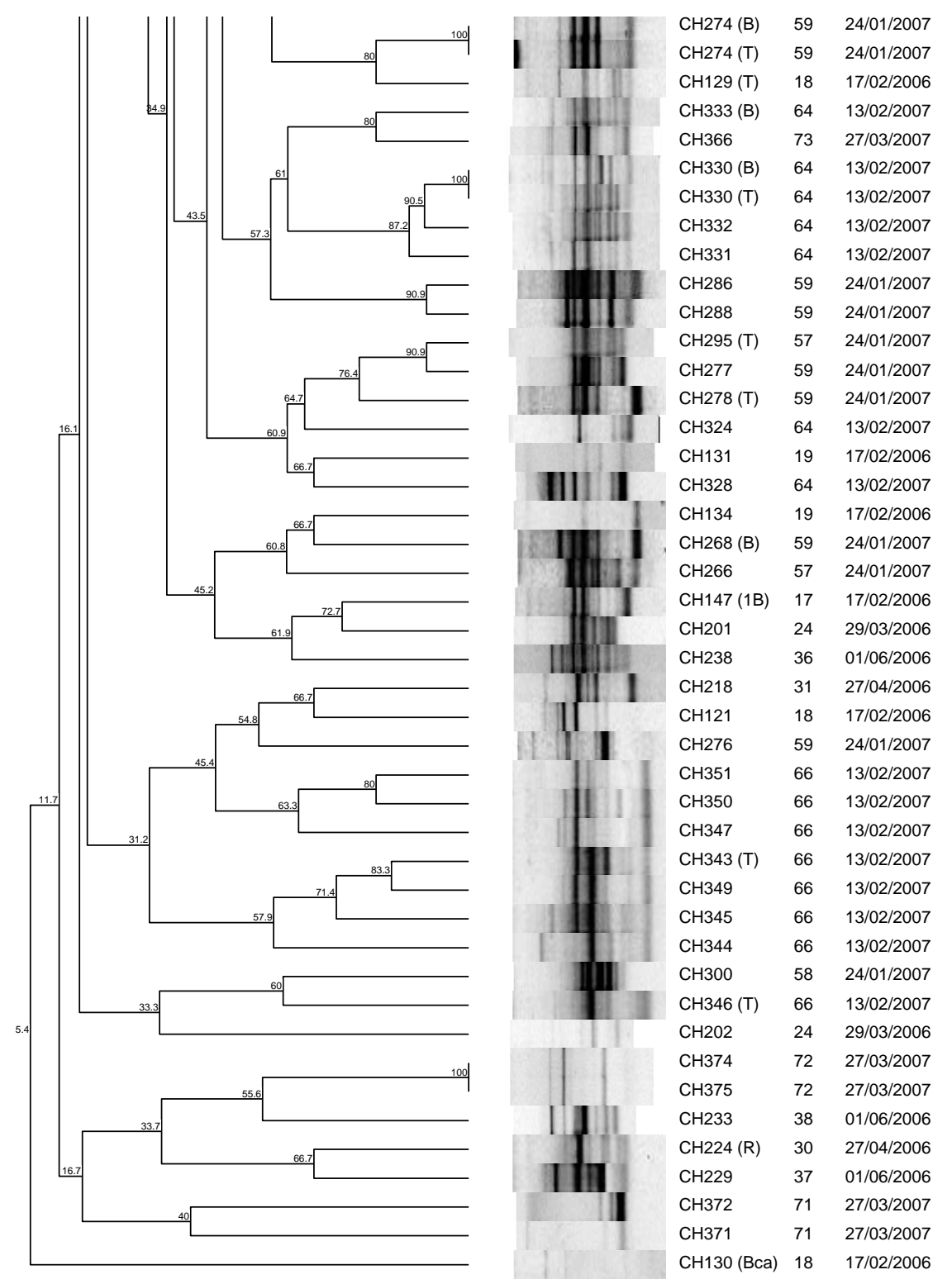

\begin{tabular}{|c|c|c|c|}
\hline 3 & GN & Bacilo & 4,15 \\
\hline & GN & Bacilo & 4,00 \\
\hline P2 & GN & Bacilo & 3,22 \\
\hline P1 & GN & Bacilo & 3,96 \\
\hline P3 & GN & Bacilo & 6,12 \\
\hline P1 & GN & Bacilo & 5,14 \\
\hline P1 & GN & Bacilo & 5,76 \\
\hline P1 & GN & Bacilo & 4,19 \\
\hline P1 & GN & Bacilo & 5,15 \\
\hline P3 & GN & Bacilo & 6,91 \\
\hline P3 & GN & Bacilo & 5,45 \\
\hline P1 & GN & Bacilo & 3,39 \\
\hline P3 & GN & Bacilo & 5,31 \\
\hline P3 & GN & Bacilo & 3,38 \\
\hline P1 & GN & Bacilo & 1,73 \\
\hline P3 & GP & Bacilo & 3,76 \\
\hline $\mathrm{P} 1$ & GN & Bacilo & 1,80 \\
\hline P3 & GN & Bacilo & 2,71 \\
\hline P3 & GN & Bacilo & 2,57 \\
\hline $\mathrm{P} 1$ & GN & Bacilo & 5,31 \\
\hline P1 & GN & Bacilo & 3,91 \\
\hline P1 & GN & Bacilo & 1,36 \\
\hline $\mathrm{P} 1$ & GN & Bacilo & 1,80 \\
\hline P3 & GN & Bacilo & 4,83 \\
\hline P2 & GP & Bacilo & 2,83 \\
\hline P3 & GN & Bacilo & 6,62 \\
\hline P3 & GN & Bacilo & 5,68 \\
\hline P3 & GN & Bacilo & 3,37 \\
\hline P3 & GN & Bacilo & 4,64 \\
\hline P3 & GN & Bacilo & 5,04 \\
\hline P3 & GN & Bacilo & 1,85 \\
\hline P3 & GN & Bacilo & 4,69 \\
\hline P3 & GN & Bacilo & 4,98 \\
\hline P2 & GP & Filamen. & 3,28 \\
\hline P3 & GN & Bacilo & 4,68 \\
\hline $\mathrm{P} 1$ & GN & Bacilo & 0,77 \\
\hline P2 & GP & Bacilo & 3,39 \\
\hline P2 & GP & Bacilo & 2,82 \\
\hline P3 & GN & Bacilo & 3,22 \\
\hline P2 & GN & Bacilo & 2,34 \\
\hline P2 & GN & Bacilo & 2,24 \\
\hline P1 & GP & Filamen. & 3,20 \\
\hline $\mathrm{P} 1$ & GP & Filamen. & 6,19 \\
\hline P2 & GN & Bacilo & 1,6 \\
\hline
\end{tabular}

Figura 37 - Dendrograma construído com a técnica de ERIC-PCR com bactérias quitinolíticas isoladas de amostras de água da Baixada Santista.

Legenda: GN - Gram-negativo; GP - Gram-positivo; Filamen. - Filamentoso; RC08-VC - V. cholerae $\mathrm{O} 1 ; 569 \mathrm{~B}-\mathrm{VC}$ - Vibrio cholerae 01.

Nota: A medida do halo de hidrólise de quitina do isolado $\mathrm{CH} 228$ foi realizada com $168 \mathrm{~h}$ de incubação. 


\section{Plâncton Marinho}

A similaridade inicial entre os 93 isolados quitinolíticos que apresentaram $\geq 2$ produtos de amplificação foi de 14,1\% pela técnica de BOX-PCR e foram obtidos 19 agrupamentos com similaridade $\geq 70 \%$. A maioria desses agrupamentos era formado por 02 isolados quitinolíticos (13 agrupamentos), mas também foram observados 02 agrupamentos contendo dois isolados, 03 agrupamentos formados por cinco isolados e 01 agrupamento composto por 12 isolados. Analisando os 19 agrupamentos citados acima, foi verificado que dez deles eram formados por bactérias quitinolíticas isoladas em datas e pontos de coleta de amostras distintos, 06 agrupamentos continham bactérias isoladas na mesma data e no mesmo ponto de coleta, dois agrupamentos eram compostos por bactérias isoladas na mesma data, porém em pontos de coleta distintos e apenas um agrupamento era formado por bactérias isoladas em datas diferentes, mas no mesmo ponto de coleta (Figura 38).

Foi verificada uma similaridade inicial de $0,5 \%$ entre os 84 isolados quitinolíticos presentes no dendrograma construído pela técnica de ERIC-PCR e 21 agrupamentos com similaridade $\geq 70 \%$ puderam ser distinguidos. Analisando os 21 agrupamentos, foi verificado que 13, 05, 02 e 01 agrupamentos eram compostos por 02, 03, 04 e 06 isolados quitinolíticos, respectivamente. A maioria desses agrupamentos (09 agrupamentos) continha bactérias quitinolíticas isoladas em datas e pontos de coletas diferentes e os outros agrupamentos eram formados por bactérias isoladas na mesma data, mas em pontos de coletas diferentes (05 agrupamentos), em datas de coleta de amostras distintas, mas no mesmo ponto de coleta (02 agrupamentos), 03 agrupamentos eram compostos por bactérias isoladas na mesma data e no mesmo ponto de coleta e dois agrupamentos eram formados entre os controles positivos e isolados quitinolíticos (RC11, RC230 e CHZ304; 569B e CHZ48) (Figura 39).

As bactérias quitinolíticas que apresentaram $\geq 70 \%$ de similaridade por ambas as técnicas de rep-PCR estão descritas na tabela 12. 
Tabela 12 - Valores de similaridades apresentadas nas técnicas de ERIC-PCR e BOX-PCR.

\begin{tabular}{lcc}
\hline \multicolumn{1}{c}{ Isolados Quitinolíticos } & \multicolumn{2}{c}{ rep-PCR } \\
\cline { 2 - 3 } & BOX-PCR & ERIC-PCR \\
\hline CHZ307 / CHZ320 & $77,7 \%$ & $100 \%$ \\
$\mathrm{CHZ201} \mathrm{/} \mathrm{CHZ202}$ & $100 \%$ & $84,9 \%$ \\
$\mathrm{CHZ201}$ / CHZ202 / CHZ203 & $100 \%$ & $100 \%$ \\
$\mathrm{CHZ206} \mathrm{/} \mathrm{CHZ217}$ & $100 \%$ & $100 \%$ \\
$\mathrm{CHZ20} \mathrm{/} \mathrm{CHZ21}$ & $100 \%$ & $100 \%$ \\
$\mathrm{CHZ196}$ / CHZ197 & $100 \%$ & $86,7 \%$ \\
$\mathrm{CHZ196} \mathrm{/} \mathrm{CHZ197} \mathrm{/} \mathrm{CHZ198}$ & $100 \%$ & \\
\hline
\end{tabular}

Pela técnica de BOX-PCR, analisando os agrupamentos com similaridade $\geq 60 \%$ e $<$ $70 \%$, foi verificada a ocorrência de dois agrupamentos formados entre bactérias grampositivas e gram-negativas. Pela técnica de ERIC-PCR, esse tipo de agrupamento não foi observado no dendrograma e em ambas as técnicas não foram observados agrupamentos com similaridade $\geq 70 \%$ ocorrido entre bactérias quitinolíticas gram-positivas e gram-negativas. 


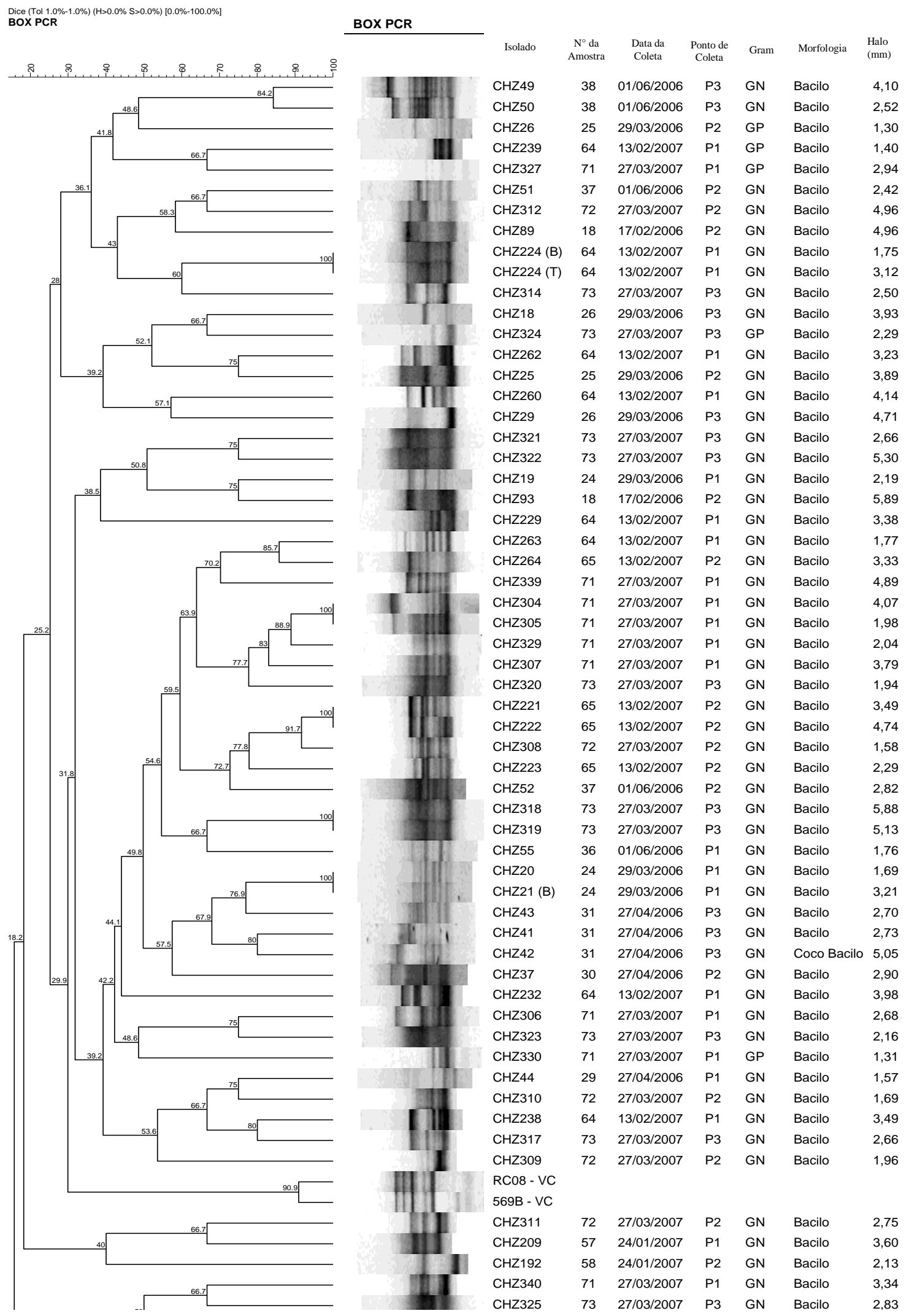

Figura 38 - Dendrograma construído com a técnica de BOX-PCR com bactérias quitinolíticas isoladas de amostras de Plâncton da Baixada Santista.

Legenda: GN - Gram-negativo; GP - Gram-positivo; Filamen. - Filamentoso; RC08-VC - V. cholerae $\mathrm{O} 1 ; 569 \mathrm{~B}-\mathrm{VC}$ - Vibrio cholerae 01. 

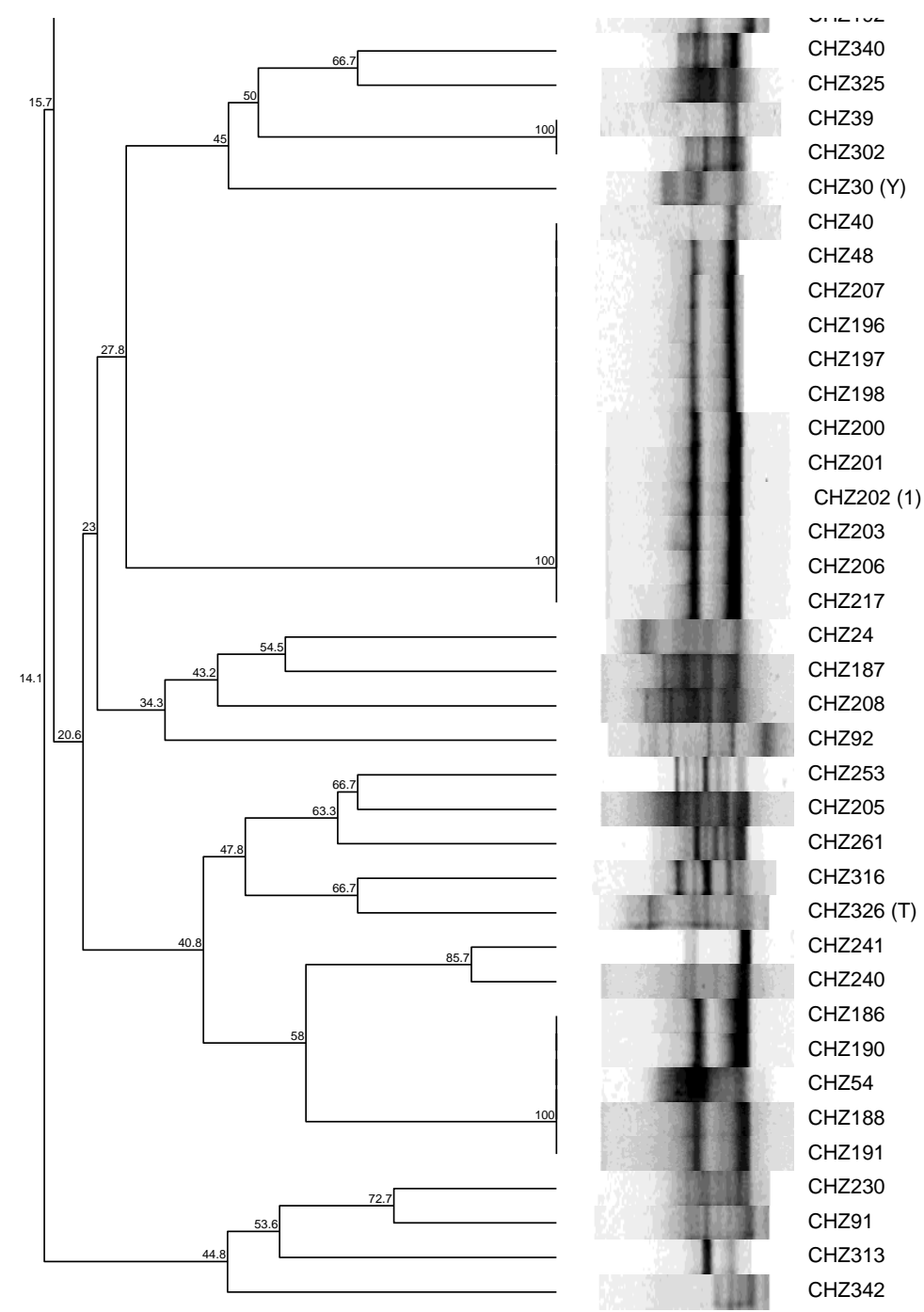

\begin{tabular}{|c|c|c|c|c|c|}
\hline$\sim$ & - & . - & $\ldots$ & -nu... &,$- \ldots$ \\
\hline 71 & $27 / 03 / 2007$ & P1 & GN & Bacilo & 3,34 \\
\hline 73 & $27 / 03 / 2007$ & P3 & GN & Bacilo & 2,83 \\
\hline 31 & $27 / 04 / 2006$ & P3 & GN & Bacilo & 2,61 \\
\hline 72 & $27 / 03 / 2007$ & $\mathrm{P} 2$ & GN & Bacilo & 2,46 \\
\hline 26 & $29 / 03 / 2006$ & P3 & GN & Bacilo & 3,54 \\
\hline 31 & $27 / 04 / 2006$ & P3 & GN & Bacilo & 1,44 \\
\hline 38 & $01 / 06 / 2006$ & P3 & GN & Bacilo & 3,55 \\
\hline 57 & $24 / 01 / 2007$ & $\mathrm{P} 1$ & GN & Bacilo & 3,88 \\
\hline 58 & $24 / 01 / 2007$ & $\mathrm{P} 2$ & GN & Bacilo & 3,84 \\
\hline 58 & $24 / 01 / 2007$ & P2 & GN & Bacilo & 4,66 \\
\hline 58 & $24 / 01 / 2007$ & $\mathrm{P} 2$ & GN & Bacilo & 3,22 \\
\hline 59 & $24 / 01 / 2007$ & P3 & GN & Bacilo & 5,39 \\
\hline 59 & $24 / 01 / 2007$ & P3 & GN & Bacilo & 3,70 \\
\hline 59 & $24 / 01 / 2007$ & P3 & GN & Bacilo & 4,79 \\
\hline 59 & $24 / 01 / 2007$ & P3 & GN & Bacilo & 3,27 \\
\hline 59 & $24 / 01 / 2007$ & P3 & GN & Bacilo & 2,93 \\
\hline 59 & $24 / 01 / 2007$ & P3 & GN & Bacilo & 3,55 \\
\hline 25 & $29 / 03 / 2006$ & P2 & GN & Bacilo & 4,56 \\
\hline 57 & $24 / 01 / 2007$ & $\mathrm{P} 1$ & GN & Bacilo & 3,90 \\
\hline 57 & $24 / 01 / 2007$ & P1 & GN & Bacilo & 5,47 \\
\hline 19 & $17 / 02 / 2006$ & P3 & GP & Bacilo & 1,68 \\
\hline 64 & $13 / 02 / 2007$ & P1 & GP & Bacilo & 2,77 \\
\hline 59 & $24 / 01 / 2007$ & P3 & GN & Bacilo & 4,48 \\
\hline 64 & $13 / 02 / 2007$ & $\mathrm{P} 1$ & GN & Bacilo & 3,71 \\
\hline 73 & $27 / 03 / 2007$ & P3 & GN & Bacilo & 1,94 \\
\hline 73 & $27 / 03 / 2007$ & P3 & GN & Bacilo & 4,11 \\
\hline 64 & $13 / 02 / 2007$ & P1 & GN & Bacilo & 2,95 \\
\hline 64 & $13 / 02 / 2007$ & $\mathrm{P} 1$ & GN & Bacilo & 5,76 \\
\hline 57 & $24 / 01 / 2007$ & P1 & GN & Bacilo & 4,45 \\
\hline 57 & $24 / 01 / 2007$ & P1 & GN & Bacilo & 3,44 \\
\hline 36 & $01 / 06 / 2006$ & P1 & GN & Bacilo & 2,53 \\
\hline 57 & $24 / 01 / 2007$ & P1 & GN & Bacilo & 3,13 \\
\hline 58 & $24 / 01 / 2007$ & P2 & GN & Bacilo & 3,44 \\
\hline 64 & $13 / 02 / 2007$ & $\mathrm{P} 1$ & GN & Bacilo & 3,83 \\
\hline 19 & $17 / 02 / 2006$ & P3 & GN & Bacilo & 2,63 \\
\hline 73 & $27 / 03 / 2007$ & P3 & GN & Bacilo & 1,11 \\
\hline 71 & $27 / 03 / 2007$ & P1 & GP & Bacilo & 3,89 \\
\hline
\end{tabular}

Figura 38 - Dendrograma construído com a técnica de BOX-PCR com bactérias quitinolíticas isoladas de amostras de Plâncton da Baixada Santista.

Legenda: GN - Gram-negativo; GP - Gram-positivo; Filamen. - Filamentoso; RC08-VC - V. cholerae $\mathrm{O1} ; 569 \mathrm{~B}-\mathrm{VC}$ - Vibrio cholerae 01. 


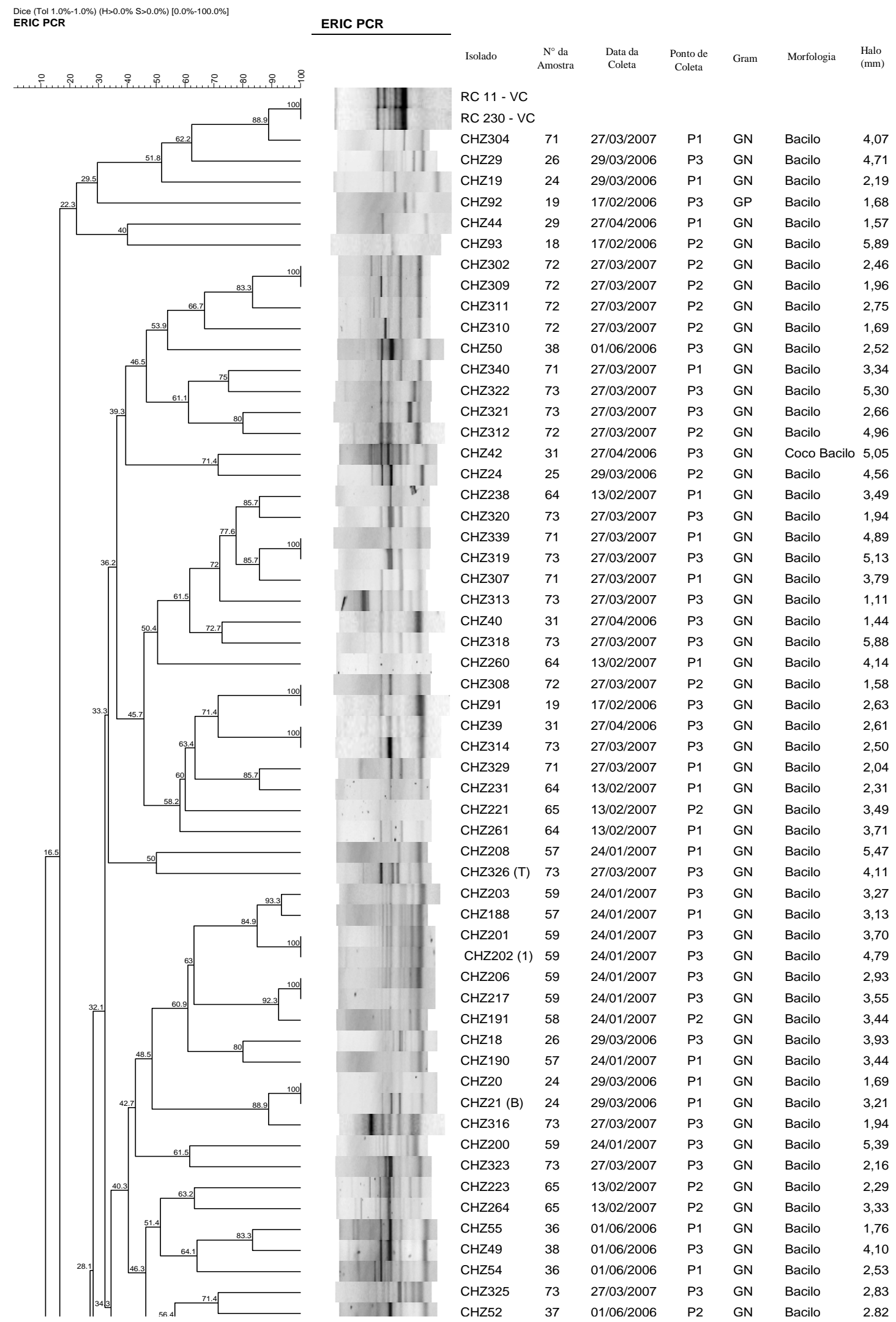

Figura 39 - Dendrograma construído com a técnica de ERIC-PCR com bactérias quitinolíticas isoladas de amostras de Plâncton da Baixada Santista.

Legenda: GN - Gram-negativo; GP - Gram-positivo; Filamen. - Filamentoso; RC08-VC - V. cholerae $\mathrm{O} 1 ; 569 \mathrm{~B}-\mathrm{VC}$ - Vibrio cholerae 01. 

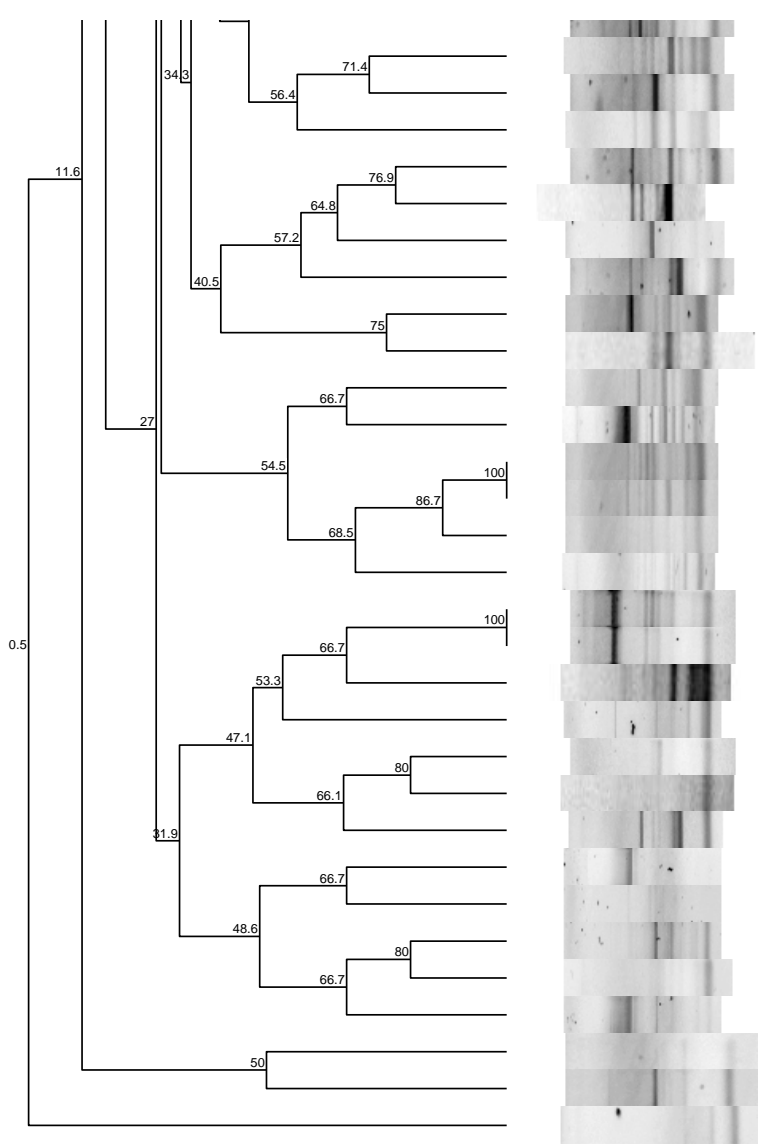

\begin{tabular}{|c|c|c|c|c|c|c|}
\hline unu. & $u$ & 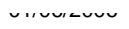 & . & a. & Luvin &,$- \cup u$ \\
\hline $\mathrm{CHZ325}$ & 73 & $27 / 03 / 2007$ & P3 & GN & Bacilo & 2,83 \\
\hline $\mathrm{CHZ52}$ & 37 & 01/06/2006 & P2 & GN & Bacilo & 2,82 \\
\hline $\mathrm{CHZ317}$ & 73 & $27 / 03 / 2007$ & P3 & GN & Bacilo & 2,66 \\
\hline $\mathrm{CHZ48}$ & 38 & 01/06/2006 & P3 & GN & Bacilo & 3,55 \\
\hline \multicolumn{7}{|l|}{$569 B-V C$} \\
\hline CHZ262 & 64 & $13 / 02 / 2007$ & P1 & GN & Bacilo & 3,23 \\
\hline $\mathrm{CHZ37}$ & 30 & $27 / 04 / 2006$ & P2 & GN & Bacilo & 2,90 \\
\hline CHZ209 & 57 & $24 / 01 / 2007$ & $\mathrm{P} 1$ & GN & Bacilo & 3,60 \\
\hline $\mathrm{CHZ30}(\mathrm{Y})$ & 26 & $29 / 03 / 2006$ & P3 & GN & Bacilo & 3,54 \\
\hline CHZ199 & 59 & $24 / 01 / 2007$ & P3 & GN & Bacilo & 3,77 \\
\hline $\mathrm{CHZ187}$ & 57 & $24 / 01 / 2007$ & P1 & GN & Bacilo & 3,90 \\
\hline $\mathrm{CHZ196}$ & 58 & $24 / 01 / 2007$ & P2 & GN & Bacilo & 3,84 \\
\hline $\mathrm{CHZ197}$ & 58 & $24 / 01 / 2007$ & P2 & GN & Bacilo & 4,66 \\
\hline CHZ198 & 58 & $24 / 01 / 2007$ & P2 & GN & Bacilo & 3,22 \\
\hline $\mathrm{CHZ186}$ & 57 & $24 / 01 / 2007$ & P1 & GN & Bacilo & 4,45 \\
\hline CHZ224 (B) & 64 & $13 / 02 / 2007$ & $\mathrm{P} 1$ & GN & Bacilo & 1,75 \\
\hline $\mathrm{CHZ224}(\mathrm{T})$ & 64 & $13 / 02 / 2007$ & P1 & GN & Bacilo & 3,12 \\
\hline $\mathrm{CHZ205}$ & 59 & $24 / 01 / 2007$ & P3 & GN & Bacilo & 4,48 \\
\hline CHZ239 & 64 & $13 / 02 / 2007$ & P1 & GP & Bacilo & 1,40 \\
\hline CHZ229 & 64 & $13 / 02 / 2007$ & $\mathrm{P} 1$ & GN & Bacilo & 3,38 \\
\hline $\mathrm{CHZ192}$ & 58 & $24 / 01 / 2007$ & P2 & GN & Bacilo & 2,13 \\
\hline $\mathrm{CHZ306}$ & 71 & $27 / 03 / 2007$ & P1 & GN & Bacilo & 2,68 \\
\hline $\mathrm{CHZ241}$ & 64 & $13 / 02 / 2007$ & P1 & GN & Bacilo & 2,95 \\
\hline CHZ230 & 64 & $13 / 02 / 2007$ & $\mathrm{P} 1$ & GN & Bacilo & 3,83 \\
\hline CHZ232 & 64 & $13 / 02 / 2007$ & P1 & GN & Bacilo & 3,98 \\
\hline $\mathrm{CHZ25}$ & 25 & $29 / 03 / 2006$ & P2 & GN & Bacilo & 3,89 \\
\hline $\mathrm{CHZ240}$ & 64 & $13 / 02 / 2007$ & P1 & GN & Bacilo & 5,76 \\
\hline $\mathrm{CHZ43}$ & 31 & $27 / 04 / 2006$ & P3 & GN & Bacilo & 2,70 \\
\hline $\mathrm{CHZ51}$ & 37 & 01/06/2006 & P2 & GN & Bacilo & 2,42 \\
\hline CHZ38 & 30 & $27 / 04 / 2006$ & P2 & GP & Bacilo & 1,56 \\
\hline
\end{tabular}

Figura 39 - Dendrograma construído com a técnica de ERIC-PCR com bactérias quitinolíticas isoladas de amostras de Plâncton da Baixada Santista.

Legenda: GN - Gram-negativo; GP - Gram-positivo; Filamen. - Filamentoso; RC08-VC - V. cholerae $\mathrm{O} 1 ; 569 \mathrm{~B}-\mathrm{VC}$ - Vibrio cholerae 01 .

\subsubsection{Sequenciamento parcial da região $16 \mathrm{~S}$ rRNA}

Em cada amostra de água do mar e plâncton foi selecionado pelo menos um isolado quitinolítico entre os isolados gram-negativos e gram-positivos (bacilos/cocos), que apresentou o maior halo de hidrólise de quitina em MMQ1 ágar. Adicionalmente, também foram selecionados isolados que apresentaram características morfológicas distintas da maioria dos isolados gram-negativos e gram-positivos obtidos em placas de MMQ1. Após a seleção dos isolados, um total de 178 bactérias quitinolíticas foram submetidos ao seqüenciamento parcial da região $16 \mathrm{~S}$ rRNA. Porém, treze delas não apresentaram resultados satisfatórios após o sequenciamento com o iniciador (primer) 1041R. Diante disso, os resultados de diversidade bacteriana que serão apresentados nesse item (5.4.3) correspondem ao sequenciamento parcial do $16 \mathrm{~S}$ rRNA de 166 bactérias quitinolíticas, sendo 32, 01 e 46 bactérias isoladas de amostras de água do mar do Canal de São Sebastião, Ubatuba e Baixada 
Santista, respectivamente e 37, 12 e 38 bactérias quitinolíticas isoladas de amostras de plâncton coletadas no Canal de São Sebastião, Ubatuba e Baixada Santista, respectivamente (Anexos I e II).

A maior porcentagem de bactérias quitinolíticas selecionadas foi classificada como Proteobacteria em ambos os tipos de amostras (água do mar e plâncton) de acordo com o sequenciamento parcial da região $16 \mathrm{~S}$ rRNA. As demais bactérias foram classificadas nos filos Firmicutes e Actinobacteria (Figura 40).
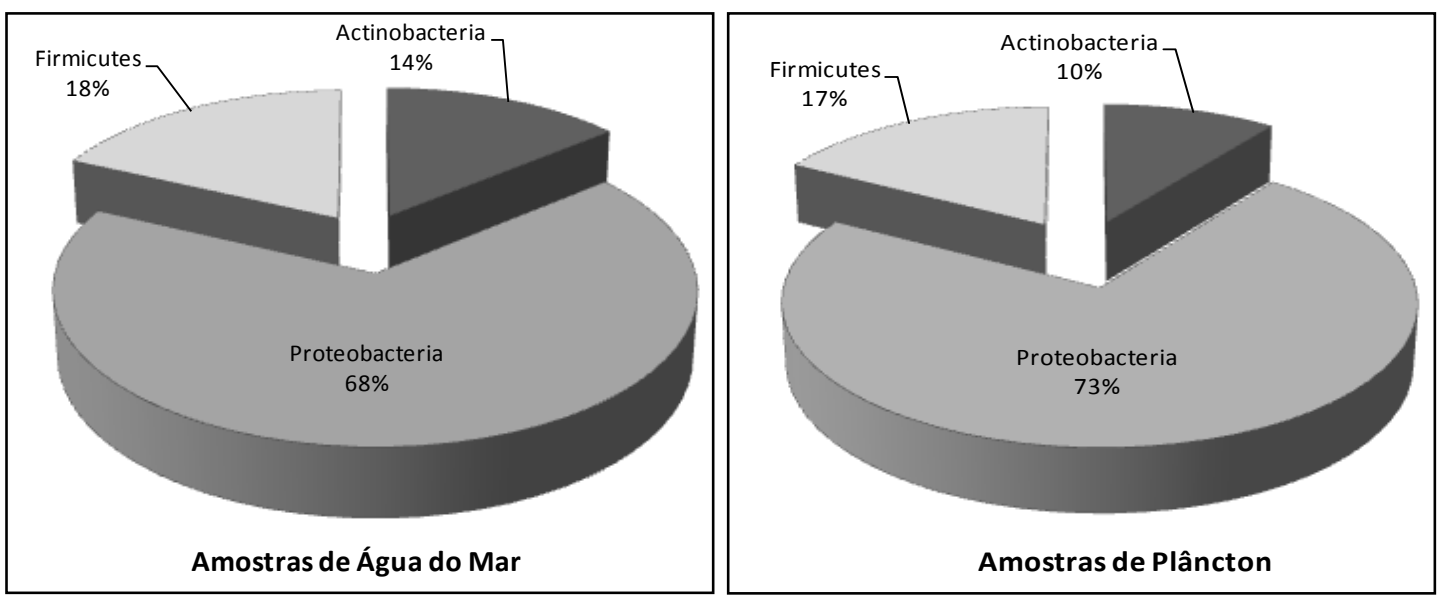

Figura 40 - Diversidade de bactérias quitinolíticas em amostras de água do mar e plâncton coletadas no Canal de São Sebastião, Ubatuba e Baixada Santista.

Entre os isolados analisados e obtidos de amostras de água do mar, a maior diversidade de bactérias quitinolíticas foi observada em amostras do Canal de São Sebastião, compreendendo onze gêneros diferentes, com prevalência de bactérias quitinolíticas pertencentes aos gêneros Aeromonas (26\%) e Paenibacillus (26\%) (Figura 41A). Na Baixada Santista foram encontradas bactérias quitinolíticas pertencentes a nove gêneros distintos, porém o gênero Aeromonas foi o mais predominante (74\%) (Figura 41B). A única bactéria gram-negativa isolada em amostras de água do mar coletada em Ubatuba pertence ao gênero Aeromonas.

Em amostras de plâncton coletadas no Canal de São Sebastião foram encontrados treze gêneros bacterianos, sendo que Aeromonas sp. foi mais frequente (24\%), seguido pelos gêneros Serratia (16\%), Paenibacillus (11\%) e Stenotrophomonas (11\%). Os demais gêneros foram encontrados com frequências inferiores a 10\% (Figura 41C). Em amostras de plâncton coletadas em Ubatuba, foram encontrados oito gêneros distintos, com maior prevalência do gênero Stenotrophomonas (33\%), seguido pelo gênero Pseudomonas (17\%). Os outros seis 
gêneros encontrados correspondiam a menos de $10 \%$ das bactérias quitinolíticas isoladas em Ubatuba, que foram submetidos ao sequenciamento parcial do 16S rRNA (Figura 41 E). Foram encontrados apenas quatro gêneros distintos em amostras de plâncton coletadas na Baixada Santista, sendo que a maior prevalência de bactérias quitinolíticas foi do gênero Aeromonas (78\%) e os outros três gêneros encontrados foram Bacillus (11\%), Paenibacillus (8\%) e Rheinheimera (3\%) (Figura $41 \mathrm{D})$.

Diante desses resultados, verificamos que a maior diversidade de bactérias quitinolíticas em amostras de plâncton foi encontrada em Ubatuba, visto que foram obtidos oito gêneros distintos após submeter ao sequenciamento da região $16 \mathrm{~S}$ rRNA apenas 12 bactérias quitinolíticas. Em contrapartida, a menor diversidade de bactérias quitinolíticas foi encontrada em amostras de plâncton coletadas na Baixada Santista.

Bactérias quitinolíticas pertencentes aos gêneros Glycomyces, Dyella, Pelomonas e Sanguibacter foram encontradas apenas em amostras de água do mar do Canal de São Sebastião, enquanto que os gêneros Vibrio e Isoptericola foram encontrados apenas em amostras de água do mar da Baixada Santista (Figura 41 A e B). Os gêneros Shewanella, Cellulosimibrobium e Ralstonia foram encontrados apenas entre as bactérias quitinolíticas isoladas de amostras de plâncton do Canal de São Sebastião e dois gêneros foram encontrados apenas em amostras de plâncton de Ubatuba: Pseudoxanthomonas e Xanthomonas. Em amostras de plâncton coletadas na Baixada Santista, os gêneros bacterianos obtidos foram encontrados também em Ubatuba e/ou no Canal de São Sebastião (Figura 41 C, D e E). 

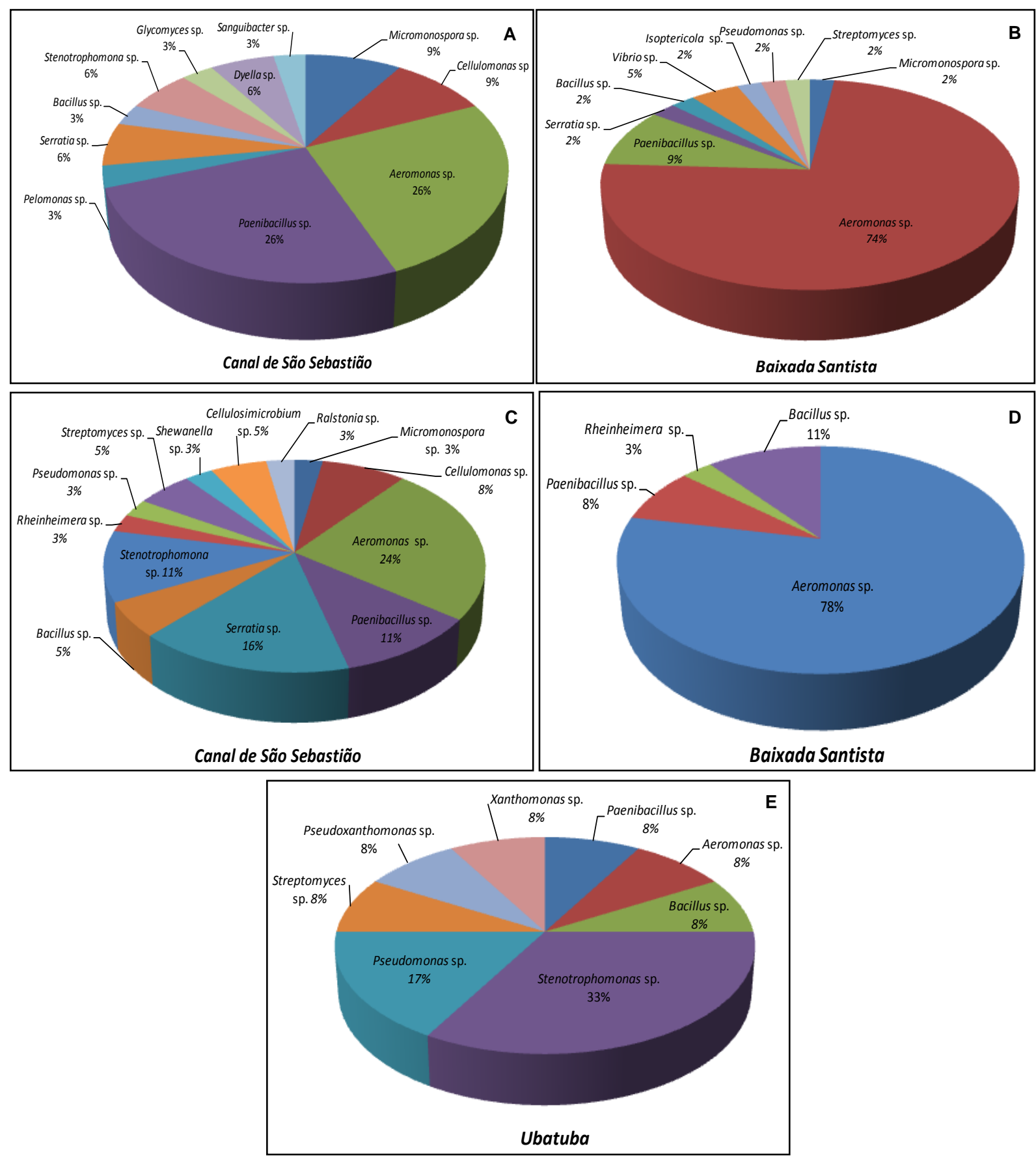

Figura 41 - Diversidade de bactérias quitinolíticas no Canal de São Sebastião, Ubatuba e Baixada Santista. Legenda: A e B - Bactérias quitinolíticas isoladas de amostras de água do Mar; C, D e E - Bactérias quitinolíticas isoladas de amostras de plâncton.

Analisando a diversidade de bactérias quitinolíticas presentes em cada local estudado, desconsiderando o tipo de amostra, foi verificado que os gêneros Cellulomonas, Cellulosimicrobium, Dyella, Glycomyces, Pelomonas, Ralstonia, Sanguibacter e Shewanella foram encontrados apenas no Canal de São Sebastião. Bactérias quitinolíticas pertencentes 
aos gêneros Pseudoxanthomonas e Xanthomonas foram exclusivos das amostras de Ubatuba, enquanto que os gêneros Vibrio e Isoptericola foram encontrados apenas na Baixada Santista, dentre os isolados analisados pela técnica de sequenciamento parcial da região $16 \mathrm{~S}$ rRNA (Figura 42).

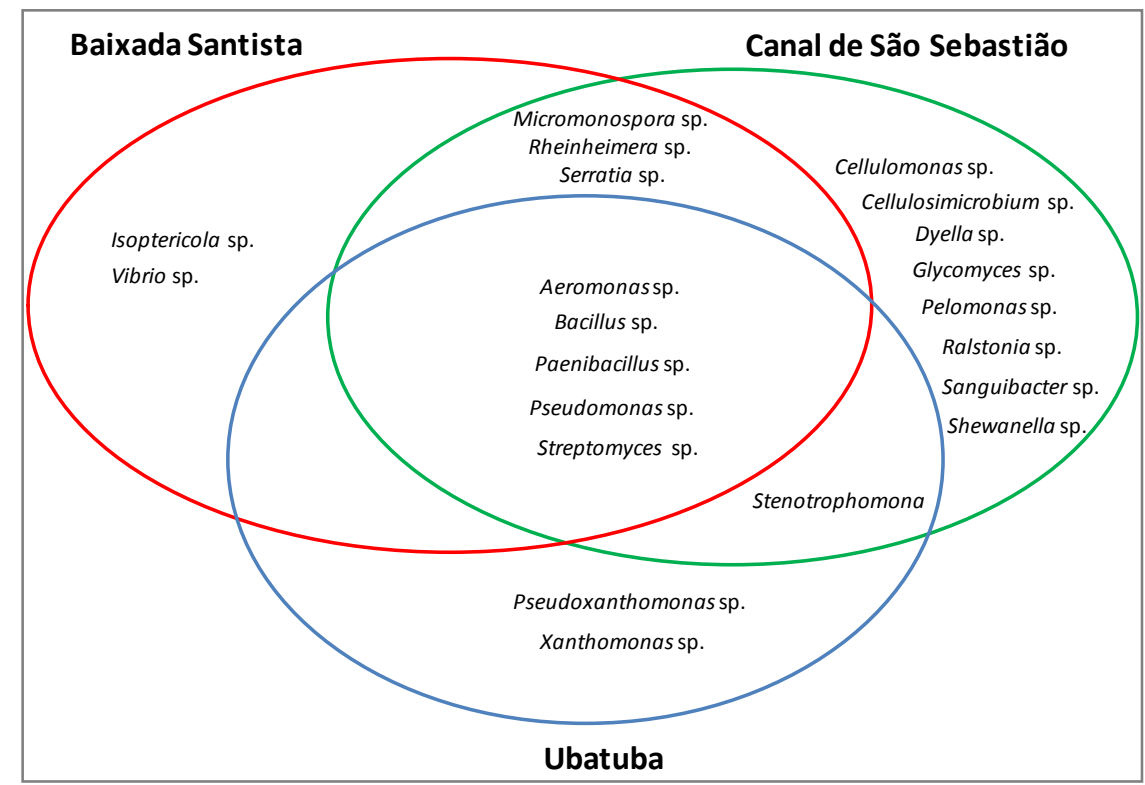

Figura 42 - Diversidade de bactérias quitinolíticas no Canal de São Sebastião, Ubatuba e Baixada Santista.

As bactérias quitinolíticas que apresentaram o mesmo gênero ao serem comparadas com sequências disponibilizadas no RDP (Ribosomal Database Project) foram alinhadas utilizando o programa BioEdit e uma bactéria quitinolítica representativa de cada gênero que apresentou > 99\% de identidade (Sequence Identity Matrix) com os demais isolados do gênero foi selecionada como bactéria representante de cada cluster, e em seguida foi construída uma árvore filogenética para cada filo como pode ser observado nas figuras 43 (Proteobacteria), 44 (Firmicutes) e 45 (Actinobacteria).

Analisando as bactérias quitinolíticas que foram comuns aos três locais de coleta, verificamos que 94\% ( $\mathrm{n}=78)$ das bactérias pertencentes ao gênero Aeromonas apresentaram $>99 \%$ de identidade entre si. No entanto, cinco bactérias quitinolíticas isoladas de amostras da Baixada Santista, as quais estão representadas pelos isolados CHZ308, CHZ223 e CHZ319 na árvore filogenética (Figura 43) apresentaram < 99\% de identidade com as demais Aeromonas sp. isoladas nesse trabalho. Duas Pseudomonas sp. (CHZ01 e CHZ184) isoladas de amostras de plâncton de Ubatuba apresentaram > 99\% de identidade com uma 
Pseudomonas sp. (CHZ234) isolada de amostra de plâncton coletada no Canal de São Sebastião e a única Pseudomonas sp. (CH324) isolada de amostra de água do mar da Baixada Santista apresentou < 99\% de identidade com as Pseudomonas sp. provenientes dos outros dois locais de coleta (Figura 43).

Dentre as vinte bactérias quitinolíticas classificadas como Paenibacillus sp. pelo sequenciamento parcial da região 16S rRNA, 35\% ( $\mathrm{n}=7)$ apresentaram < 99\% de identidade com todos os outros Paenibacillus sp. obtidos nesse trabalho. Dois agrupamentos, representados pelas bactérias $\mathrm{CH} 81$ e $\mathrm{CH} 374$, são formados por bactérias quitinolíticas isoladas no mesmo dia de coleta e no mesmo tipo de amostra. $\mathrm{O}$ agrupamento representado pela bactéria quitinolítica CHZ92 é composto por duas bactérias quitinolíticas que apresentaram > 99\% de identidade entre si, porém a bactéria CHZ92 foi isolada de amostra de plâncton coletada na Baixada Santista enquanto que o outro isolado de amostra de água do mar do Canal de São Sebastião. A bactéria quitinolítica CH53 apresentou > 99\% de identidade com outras seis bactérias quitinolíticas isoladas dos três locais de coleta e nos dois tipos de amostras (água do mar e plâncton) (Figura 44).

A bactéria quitinolítica $\mathrm{CH} 227$ isolada de amostra de água do mar coletada na Baixada Santista sp., apresentou > 99\% de identidade com seis bactérias quitinolíticas classificadas como Bacillus sp. e isoladas de amostras de água do mar e plâncton coletadas no Canal de São Sebastião e Baixada Santista. O único Bacillus sp. (CHZ257) proveniente de amostras de Ubatuba apresentou < 99\% de identidade com os outros Bacillus sp. identificados nesse estudo (Figura 44).

As quatro bactérias quitinolíticas pertencentes ao filo Actinobacteria e identificadas como Streptomyces sp. e isoladas do Canal de São Sebastião, Baixada Santista e Ubatuba apresentaram < 99\% de identidade entre si. A bactéria quitinolítica $\mathrm{CHZ140}_{1}$, isolada de uma amostra de plâncton coletada no Canal de São Sebastião, apresentou > 99\% de identidade com uma Cellulomonas sp. (CH04) isolada de amostra de água do mar do também do Canal de São Sebastião e com duas bactérias quitinolíticas (CHZ141 e CHZ139B) isoladas de amostras de plâncton. No entanto, essas duas últimas bactérias quitinolíticas foram isoladas no mesmo local e no mesmo dia de coleta que foi isolada a bactéria CHZ140 ${ }_{1}$. 


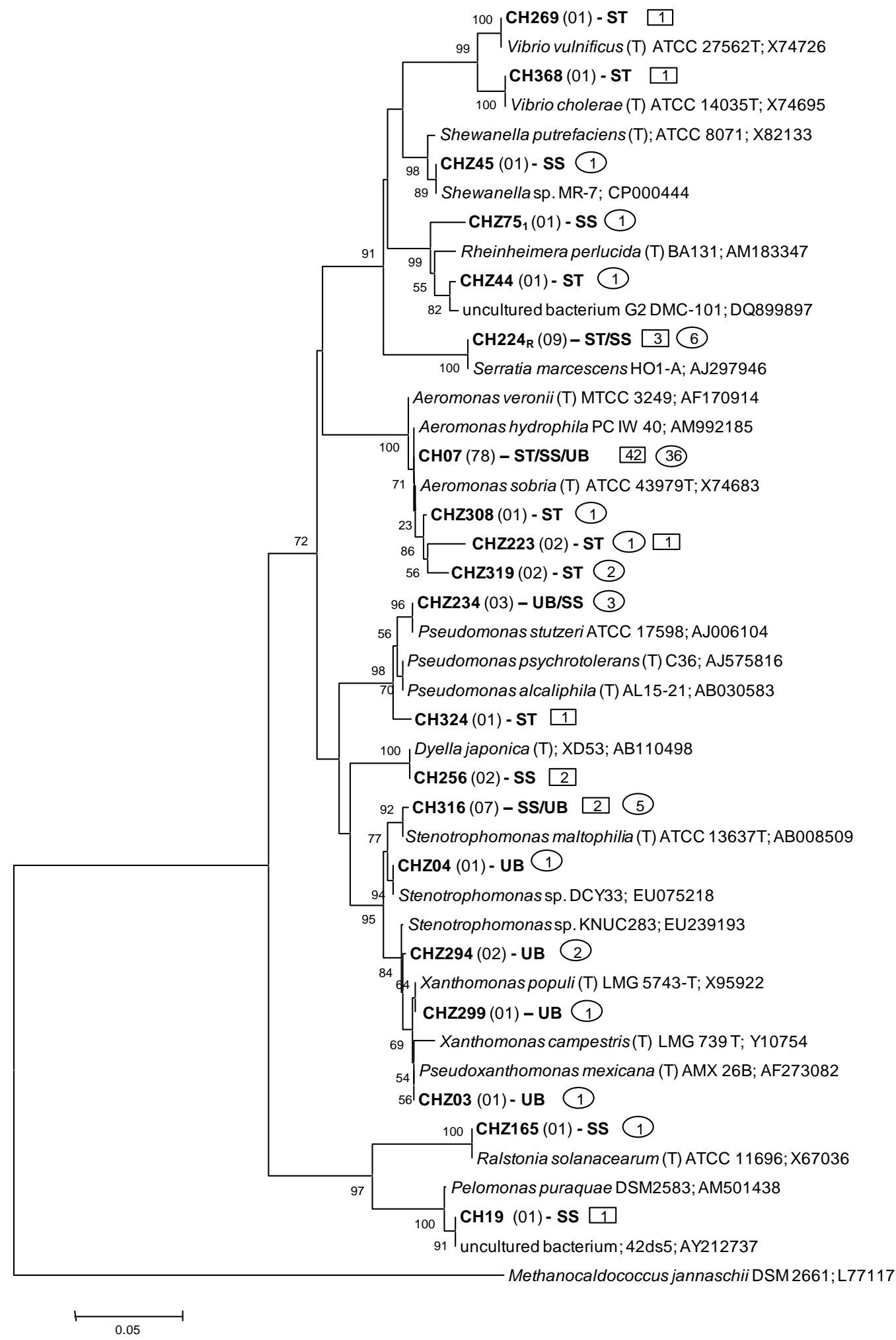

Figura 43 - Árvore filogenética baseada na comparação das sequências do gene 16S rDNA das bactérias quitinolíticas pertencentes ao filo Proteobacteria com as sequências disponíveis no RDP. Os valores de bootstrap $<50$ foram retirados da figura acima.

Legenda:

( ): Número de isolados que apresentaram >99\% de identidade entre si; SS: Canal de São Sebastião / UB: Ubatuba / ST: Baixada Santista

Bactéria quitinolítica isolada de amostra de água do mar:

Bactéria quitinolítica isolada de amostra de plâncton

Nota: Os números no interior das figuras acima obtidos de cada tipo de amostra. correspondem ao número de isolados 


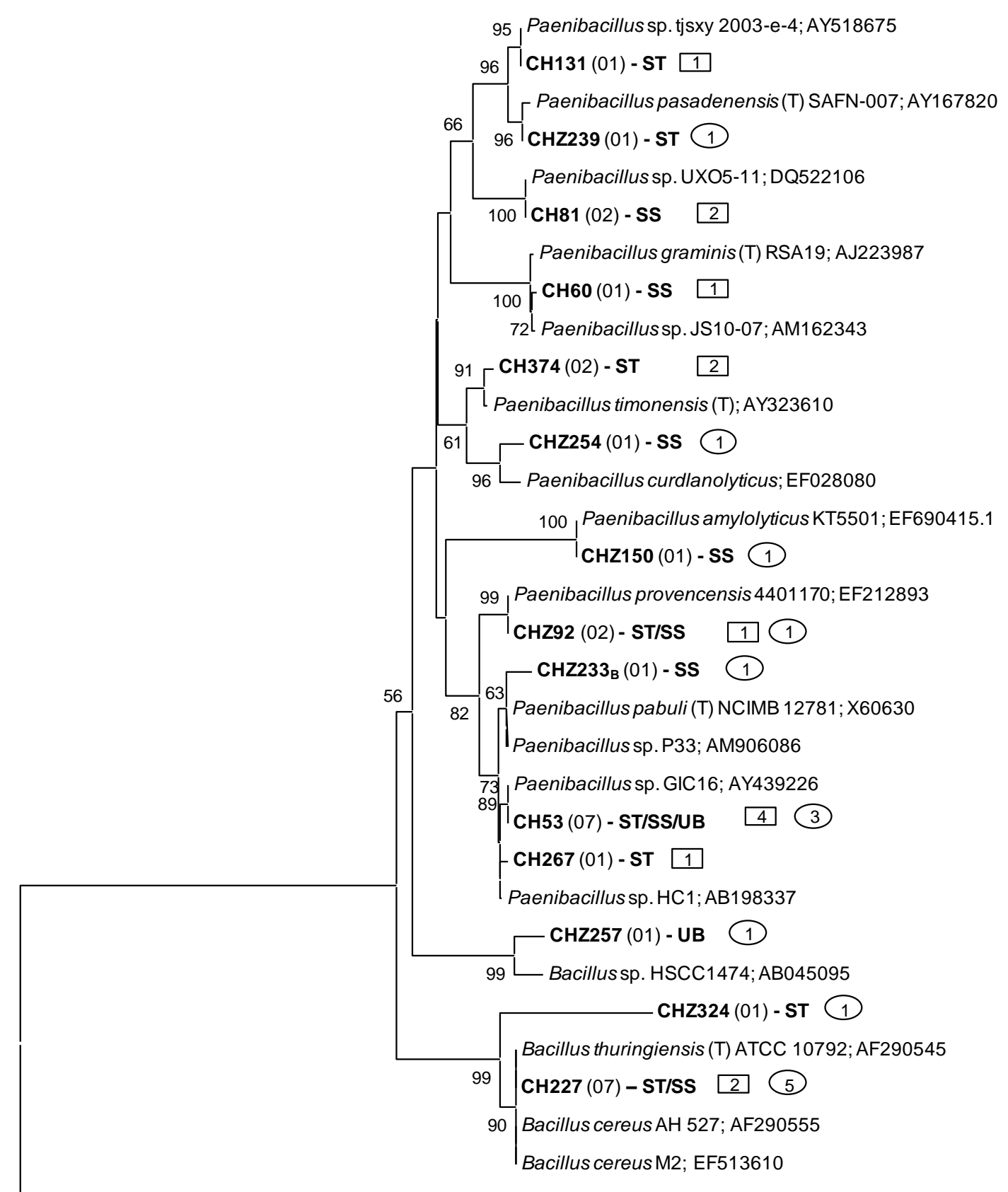

Methanocaldococcus jannaschii DSM 2661;L77117

0.05

Figura 44 - Árvore filogenética baseada na comparação das sequências do gene 16S rDNA das bactérias quitinolíticas pertencentes ao filo Firmicutes com as sequências disponíveis no RDP. Os valores de bootstrap $<50$ foram retirados da figura acima.

Legenda:

( ): Número de isolados que apresentaram >99\% de identidade entre si; SS: Canal de São Sebastião / UB: Ubatuba / ST: Baixada Santista

Bactéria quitinolítica isolada de amostra de água do mar:

Bactéria quitinolítica isolada de amostra de plâncton

Nota: Os números no interior das figuras acima

correspondem ao número de isolados obtidos de cada tipo de amostra. 


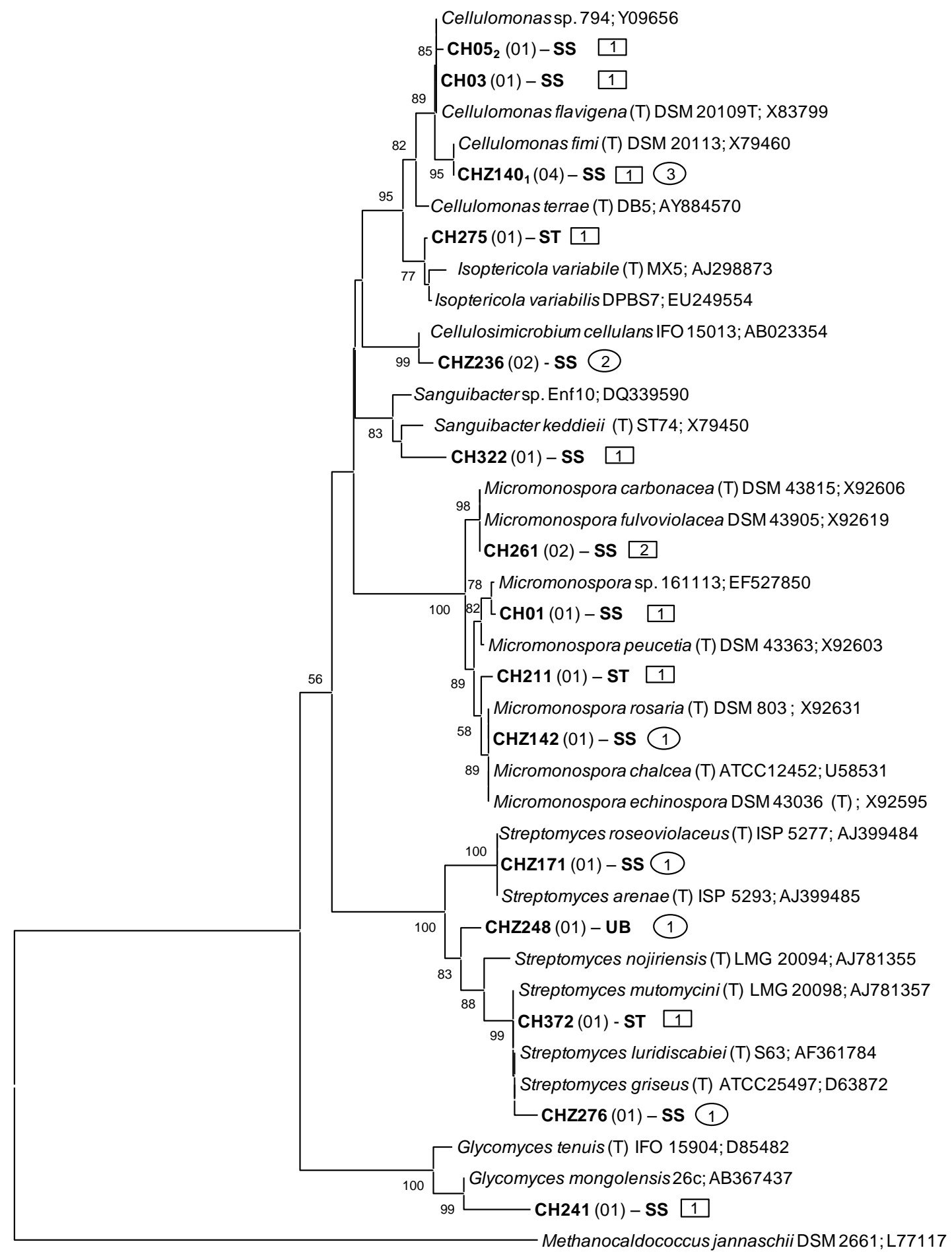

0.05

Figura 45 - Árvore filogenética baseada na comparação das sequências do gene 16S rDNA das bactérias quitinolíticas pertencentes ao filo Actinobacteria com as sequências disponíveis no RDP. Os valores de bootstrap $<50$ foram retirados da figura acima.

Legenda:

( ): Número de isolados que apresentaram >99\% de identidade entre si; SS: Canal de São Sebastião / UB:

Ubatuba / ST: Baixada Santista

Bactéria quitinolítica isolada de amostra de água do mar:

Bactéria quitinolítica isolada de amostra de plâncton

Nota: Os números no interior das figuras acima obtidos de cada tipo de amostra.

correspondem ao número de isolados 


\subsubsection{Comparação entre as técnicas de rep-PCR, seqüienciamento parcial da região $16 \mathrm{~S}$ rRNA das bactérias quitinolíticas e atividade enzimática}

As 166 bactérias quitinolíticas submetidas ao seqüenciamento parcial da região $16 \mathrm{~S}$ rRNA foram analisadas em relação ao perfil genômico apresentado pelas técnicas de BOXPCR e ERIC-PCR. Para isto, foi construído um dendrograma para cada técnica, contendo apenas os isolados que foram identificados pelo seqüenciamento (Figuras 46 e 47).

O dendrograma obtido pela técnica de BOX-PCR apresentou uma similaridade inicial de $10,4 \%$ entre os 163 isolados quitinolíticos que apresentaram > 2 produtos de amplificação e foram obtidos 40 agrupamentos com similaridade $\geq 70 \%$. Dentre esses agrupamentos, foram observados 01 02, 09 e 31 agrupamentos formados respectivamente, por 05, 04, 03 e 02 bactérias quitinolíticas, sendo que 15 agrupamentos (35\%) eram formados por bactérias pertencentes a filos diferentes, $06(14 \%)$ eram formados por bactérias classificadas no mesmo filo, mas eram de gêneros diferentes e $22(51 \%)$ agrupamentos eram formados por bactérias quitinolíticas pertencentes ao mesmo gênero (Figura 46).

Pela técnica de ERIC-PCR, a similaridade inicial entre os 130 isolados quitinolíticos que apresentaram $>2$ produtos de amplificação foi de 5,2\%. Foram obtidos 27 agrupamentos com similaridade $\geq 70 \%$, dos quais 01, 01, 04 e 21 agrupamentos eram formados por 06, 05, 03 e 02 isolados quitinolíticos, respectivamente. Foi verificado que $22(81 \%)$ agrupamentos eram formados por bactérias pertencentes ao mesmo gênero, 01 (4\%) agrupamento era formado por bactérias classificadas no mesmo filo, porém eram de gêneros diferentes e 04 (15\%) agrupamentos eram formados por bactérias pertencentes a filos diferentes (Figura 47).

Apenas as bactérias quitinolíticas identificadas como Aeromonas sp. foram analisadas separadamente em relação ao perfil genômico apresentado pelas técnicas de BOX-PCR e ERIC-PCR, visto que esse foi o maior grupo de bactérias obtidas nesse trabalho (Figura 48 e 49).

Os dendrogramas obtidos permitiram observar uma alta diversidade genética entre os indivíduos desse gênero bacteriano, visto que pela técnica de BOX-PCR a similaridade inicial entre as 83 Aeromonas sp. que apresentaram > 2 produtos de amplificação foi de $14,6 \%$ e pela técnica de ERIC-PCR, a similaridade inicial entre as 81 Aeromonas sp. que apresentaram > 2 produtos de amplificação foi de 15,7\%.

Pela técnica de BOX-PCR foram obtidos 22 agrupamentos com similaridade $\geq 70 \%$, sendo que $68 \%$ dos agrupamentos eram formados por apenas duas bactérias, $27 \%$ eram 
constituídos por 03 bactérias e $05 \%$ eram formados por quatro Aeromonas sp. Foi verificado que 03 dos agrupamentos que apresentaram similaridade $\geq 70 \%$ eram formados por Aeromonas sp. provenientes de amostras de água do mar coletadas em diferentes locais, 01 agrupamento era formado por bactérias isoladas de amostras de água do mar e plâncton coletadas em locais distintos, 02 eram constituídos por Aeromonas sp. isoladas de amostras de plâncton coletadas em locais diferentes, 04 agrupamentos eram formados por duas bactérias isoladas de amostras de água do mar e plâncton coletadas no mesmo local e, finalmente, o restante dos agrupamentos eram constituídos por Aeromonas sp. provenientes do mesmo tipo de amostra e do mesmo local (Figura 48).

O dendrograma construído com as Aeromonas sp. submetidas à técnica de ERIC-PCR mostrou 17 agrupamentos com $\geq 70 \%$ de similaridade. Desses agrupamentos, 70,5\% eram formados por apenas duas bactérias, 23,5\% eram constituídos por 03 bactérias e $06 \%$ eram formados por 05 Aeromonas sp. Dentre os 17 agrupamentos obtidos por essa técnica, foram observados 05 agrupamentos formados por bactérias isoladas de amostras de água do mar e plâncton coletadas em locais distintos, 01 agrupamento era formado por duas bactérias isoladas de amostras de água do mar e plâncton coletadas no mesmo local e, 10 agrupamentos eram constituídos por Aeromonas sp. provenientes do mesmo tipo de amostra e do mesmo local (Figura 49).

Em relação ao diâmetro do halo de hidrólise de quitina, foi verificado que das 166 bactérias quitinolíticas identificadas pelo sequenciamento da região 16S rRNA, 20 (91\%) bactérias dentre 22 bactérias que apresentaram > 5,0 $\mathrm{mm}$ de diâmetro do halo, foram classificadas como Aeromonas sp. As outras duas bactérias foram identificadas como Xanthomonas sp. e Paenibacillus sp (Figura 49).

Foi verificado que $100 \%$ das bactérias quitinolíticas que apresentaram $>3,0 \mathrm{U}$ de enzimas necessárias para liberar $1,0 \mu \mathrm{mol}$ de GlcNAc a $37{ }^{\circ} \mathrm{C}$ e as quatro bactérias quitinolíticas que produziram $>1,0 \mathrm{U}$ de $\beta$ - $N$-acetil-glicosaminidase foram identificadas como Aeromonas sp. Em relação às outras duas enzimas: quitobiosidade e endoquitinase, dentre as 29 bactérias que foram selecionadas para realização a quantificação dessas duas enzimas, 17 foram identificadas pelo seqüenciamento da região $16 \mathrm{~S}$ rRNA, e dessas, 16 foram classificadas como Aeromonas sp. e uma foi identificada como Paenibacillus sp. 


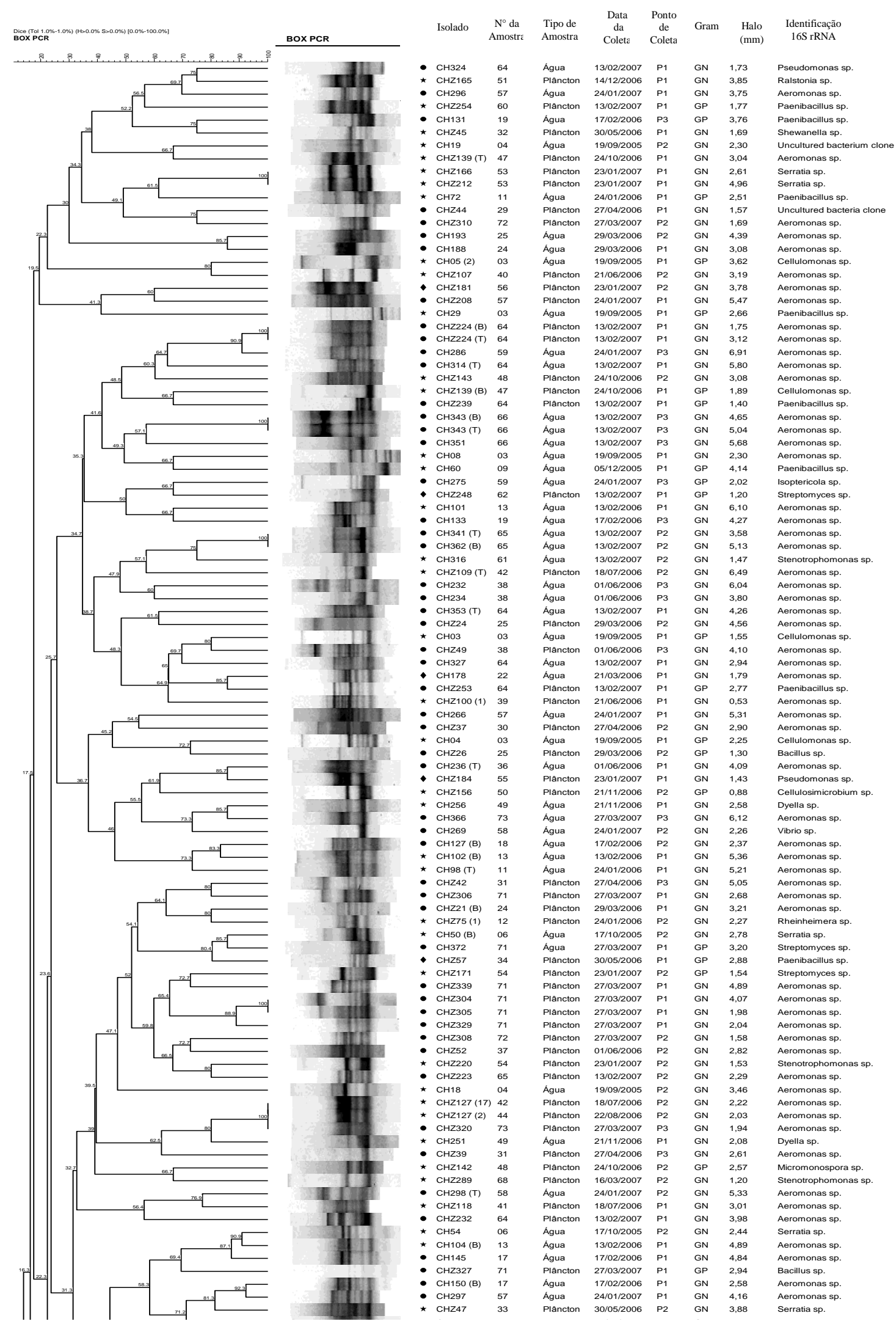

Figura 46 - Dendrograma construído com a técnica de BOX-PCR com bactérias quitinolíticas identificadas pelo sequenciamento da região $16 \mathrm{~S}$ rRNA.

Legenda: GN - Gram-negativo; GP - Gram-positivo; •: Bactérias isoladas na Baixada Santista; *: Bactérias isoladas no Canal de São Sebastião; $\bullet$ : Bactérias isoladas em Ubatuba. 

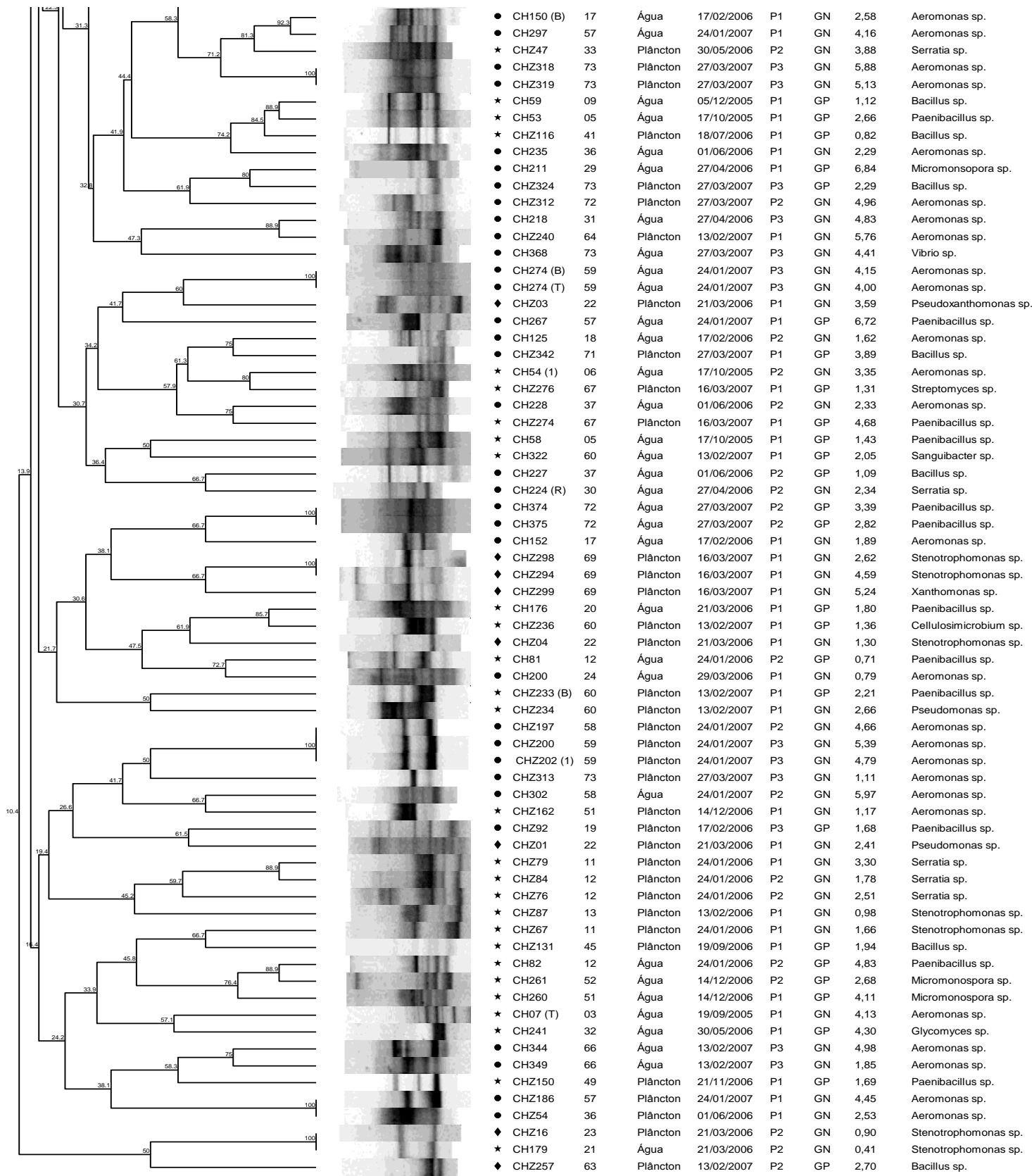

Figura 46 - Dendrograma construído com a técnica de BOX-PCR com bactérias quitinolíticas identificadas pelo sequenciamento da região $16 \mathrm{~S}$ rRNA.

Legenda: GN - Gram-negativo; GP - Gram-positivo; •: Bactérias isoladas na Baixada Santista; *: Bactérias isoladas no Canal de São Sebastião; $\bullet$ : Bactérias isoladas em Ubatuba. 


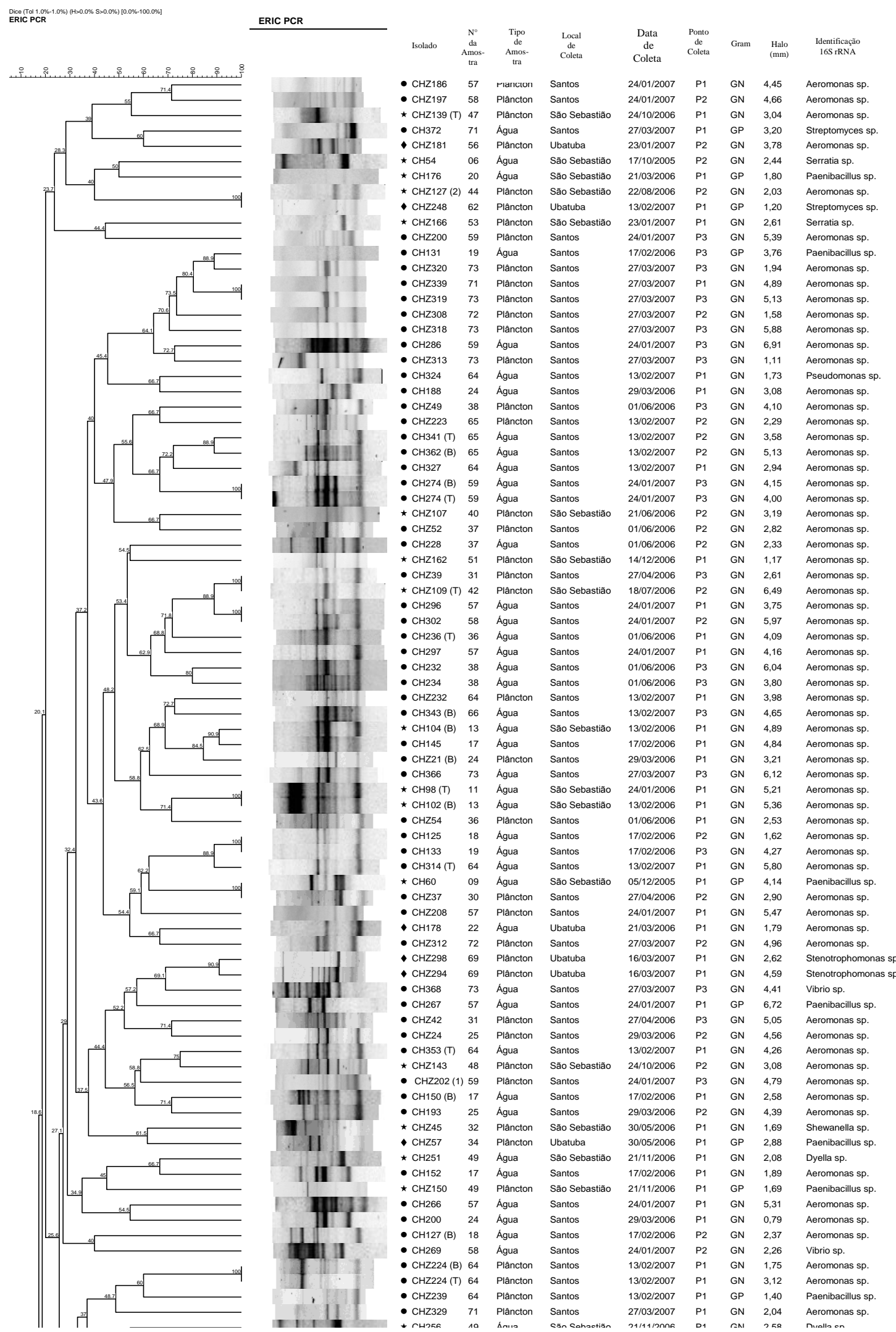

Figura 47 - Dendrograma construído com a técnica de ERIC-PCR com bactérias quitinolíticas identificadas pelo sequenciamento da região $16 \mathrm{~S}$ rRNA.

Legenda: GN - Gram-negativo; GP - Gram-positivo; •: Bactérias isoladas na Baixada Santista; *: Bactérias isoladas no Canal de São Sebastião; $\bullet$ : Bactérias isoladas em Ubatuba. 

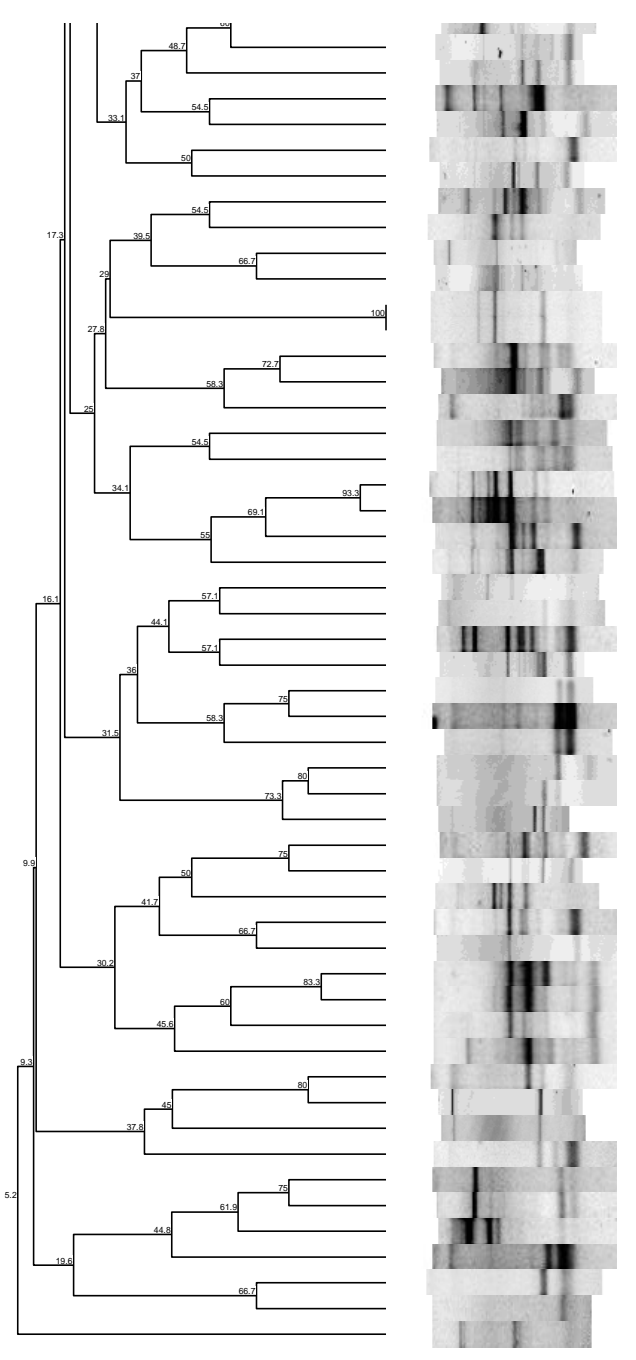

\begin{tabular}{|c|c|c|c|c|}
\hline & & & & \\
\hline $\mathrm{HZ2}$ & 64 & Plâncton & Santos & 13/02/2007 \\
\hline - CHZ329 & 71 & Plâncton & Santos & $27 / 03 / 2007$ \\
\hline$\star \mathrm{CH} 256$ & 49 & Água & São Sebastião & $21 / 11 / 2006$ \\
\hline$\star$ ¿ CHZ118 & 41 & Plâncton & São Sebastião & 18/07/2006 \\
\hline$\star \mathrm{CH} 101$ & 13 & Água & São Sebastião & 13/02/2006 \\
\hline - $\mathrm{CHZ} 310$ & 72 & Plâncton & Santos & $27 / 03 / 2007$ \\
\hline$\star \mathrm{CHZ100}(1)$ & 39 & Plâncton & São Sebastião & $21 / 06 / 2006$ \\
\hline$\star \mathrm{CHZ75}(1)$ & 12 & Plâncton & São Sebastião & $24 / 01 / 2006$ \\
\hline - CHZ184 & 55 & Plâncton & Ubatuba & $23 / 01 / 2007$ \\
\hline - $\mathrm{CHZ} 240$ & 64 & Plâncton & Santos & 13/02/2007 \\
\hline - $\mathrm{CH} 374$ & 72 & Água & Santos & $27 / 03 / 2007$ \\
\hline - $\mathrm{CH} 375$ & 72 & Água & Santos & 27/03/2007 \\
\hline - $\mathrm{CH} 224$ (R) & 30 & Água & Santos & 27/04/2006 \\
\hline$\star \mathrm{CHZ} 47$ & 33 & Plâncton & São Sebastião & $30 / 05 / 2006$ \\
\hline$\star \mathrm{CH} 316$ & 61 & Água & São Sebastião & 13/02/2007 \\
\hline - $\mathrm{CH} 235$ & 36 & Água & Santos & 01/06/2006 \\
\hline - $\mathrm{CH} 298$ (T) & 58 & Água & Santos & $24 / 01 / 2007$ \\
\hline ^ $\mathrm{CH} 82$ & 12 & Água & São Sebastião & $24 / 01 / 2006$ \\
\hline$\star$ ¿ $\mathrm{CH} 53$ & 05 & Água & São Sebastião & 17/10/2005 \\
\hline - $\mathrm{CH} 218$ & 31 & Água & Santos & $27 / 04 / 2006$ \\
\hline$\star$ « $\mathrm{CHOB}$ & 03 & Água & São Sebastião & 19/09/2005 \\
\hline$\star$ ¿ CHZ165 & 51 & Plâncton & São Sebastião & 14/12/2006 \\
\hline$\star$ « CHZ289 & 68 & Plâncton & São Sebastião & $16 / 03 / 2007$ \\
\hline CH54 (1) & 06 & Água & São Sebastião & 17/10/2005 \\
\hline - $\mathrm{CHZ} 306$ & 71 & Plâncton & Santos & $27 / 03 / 2007$ \\
\hline$\star \mathrm{CHZ} 84$ & 12 & Plâncton & São Sebastião & $24 / 01 / 2006$ \\
\hline$\star$ ¿ $\mathrm{CH} 50$ (B) & 06 & Água & São Sebastião & 17/10/2005 \\
\hline$\star$ CHZ79 & 11 & Plâncton & São Sebastião & $24 / 01 / 2006$ \\
\hline$\star$ CHZ76 & 12 & Plâncton & São Sebastião & $24 / 01 / 2006$ \\
\hline - $\mathrm{CHZ92}$ & 19 & Plâncton & Santos & 17/02/2006 \\
\hline CHZ212 & 53 & Plâncton & São Sebastião & $23 / 01 / 2007$ \\
\hline$\star \mathrm{CH} 18$ & 04 & Água & São Sebastião & 19/09/2005 \\
\hline - $\mathrm{CHZ} 304$ & 71 & Plâncton & Santos & $27 / 03 / 2007$ \\
\hline$\star$ « $\mathrm{CH} 29$ & 03 & Água & São Sebastião & 19/09/2005 \\
\hline $\mathrm{CHO7}$ (T) & 03 & Água & São Sebastião & 19/09/2005 \\
\hline - $\mathrm{CHZ} 44$ & 29 & Plâncton & Santos & 27/04/2006 \\
\hline - $\mathrm{CH} 343(\mathrm{~T})$ & 66 & Água & Santos & $13 / 02 / 2007$ \\
\hline CH349 & 66 & Água & Santos & 13/02/2007 \\
\hline - $\mathrm{CH} 351$ & 66 & Água & Santos & 13/02/2007 \\
\hline - $\mathrm{CH} 344$ & 66 & Água & Santos & 13/02/2007 \\
\hline$\star \mathrm{CH} 179$ & 21 & Água & São Sebastião & $21 / 03 / 2006$ \\
\hline CHZ299 & 69 & Plânc & Ubatuba & $16 / 03 / 2007$ \\
\hline$\star \mathrm{CHZ141}$ & 47 & Plâncton & São Sebastião & $24 / 10 / 2006$ \\
\hline$\star \mathrm{CH}_{19}$ & 04 & Água & São Sebastião & 19/09/2005 \\
\hline CH81 & 12 & Água & São Sebastião & $24 / 01 / 2006$ \\
\hline ^ CH72 & 11 & Agua & São Sebastiâo & 24/01/2006 \\
\hline$\star$ С & 60 & Água & São Sebastião & 13/02/2007 \\
\hline CH58 & 05 & Água & São Sebastião & 17/10/2005 \\
\hline$\star \mathrm{CH} 260$ & 51 & Água & São Sebastião & 14/12/2006 \\
\hline$\star$ CHZ233 (B) & 60 & Plâncton & São Sebastião & 13/02/2007 \\
\hline 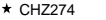 & 67 & Plâncton & São Sebastião & 16/03/2007 \\
\hline
\end{tabular}

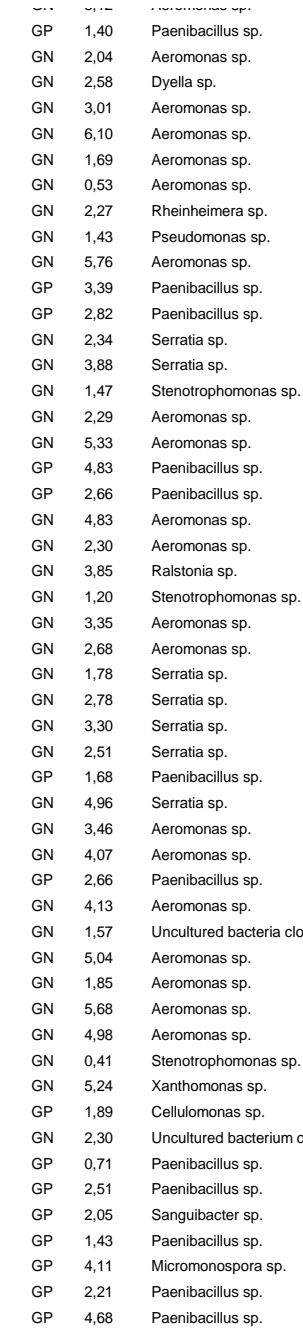

Figura 47 - Dendrograma construído com a técnica de ERIC-PCR com bactérias quitinolíticas identificadas pelo sequenciamento da região $16 \mathrm{~S}$ rRNA.

Legenda: GN - Gram-negativo; GP - Gram-positivo; •: Bactérias isoladas na Baixada Santista; *: Bactérias isoladas no Canal de São Sebastião; $\bullet$ : Bactérias isoladas em Ubatuba. 


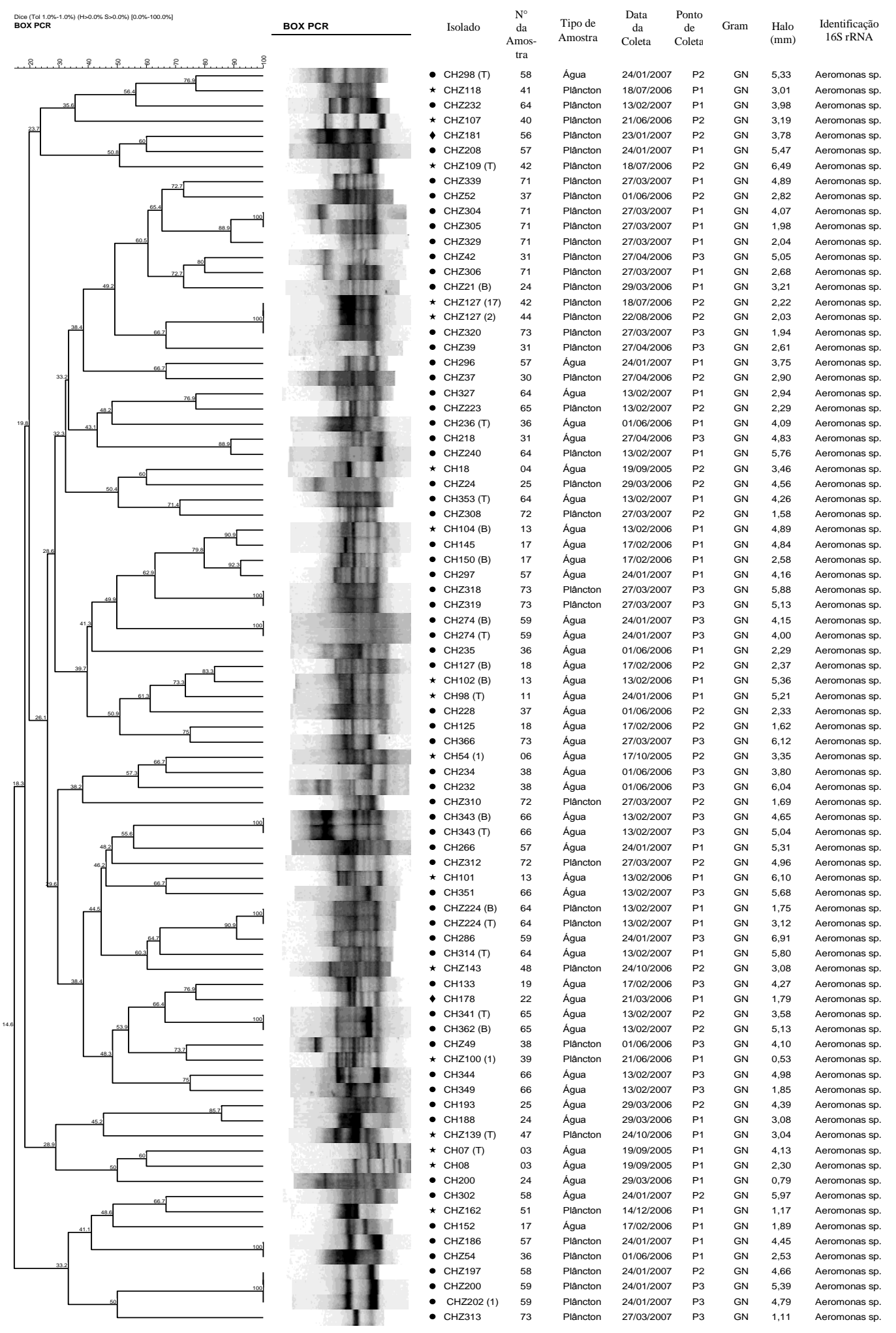

Figura 48 - Dendrograma construído com a técnica de BOX-PCR com bactérias quitinolíticas identificadas como Aeromonas sp. pelo sequenciamento da região 16S rRNA.

Legenda: GN - Gram-negativo; GP - Gram-positivo; •: Bactérias isoladas na Baixada Santista; *: Bactérias isoladas no Canal de São Sebastião; $\bullet$ : Bactérias isoladas em Ubatuba. 


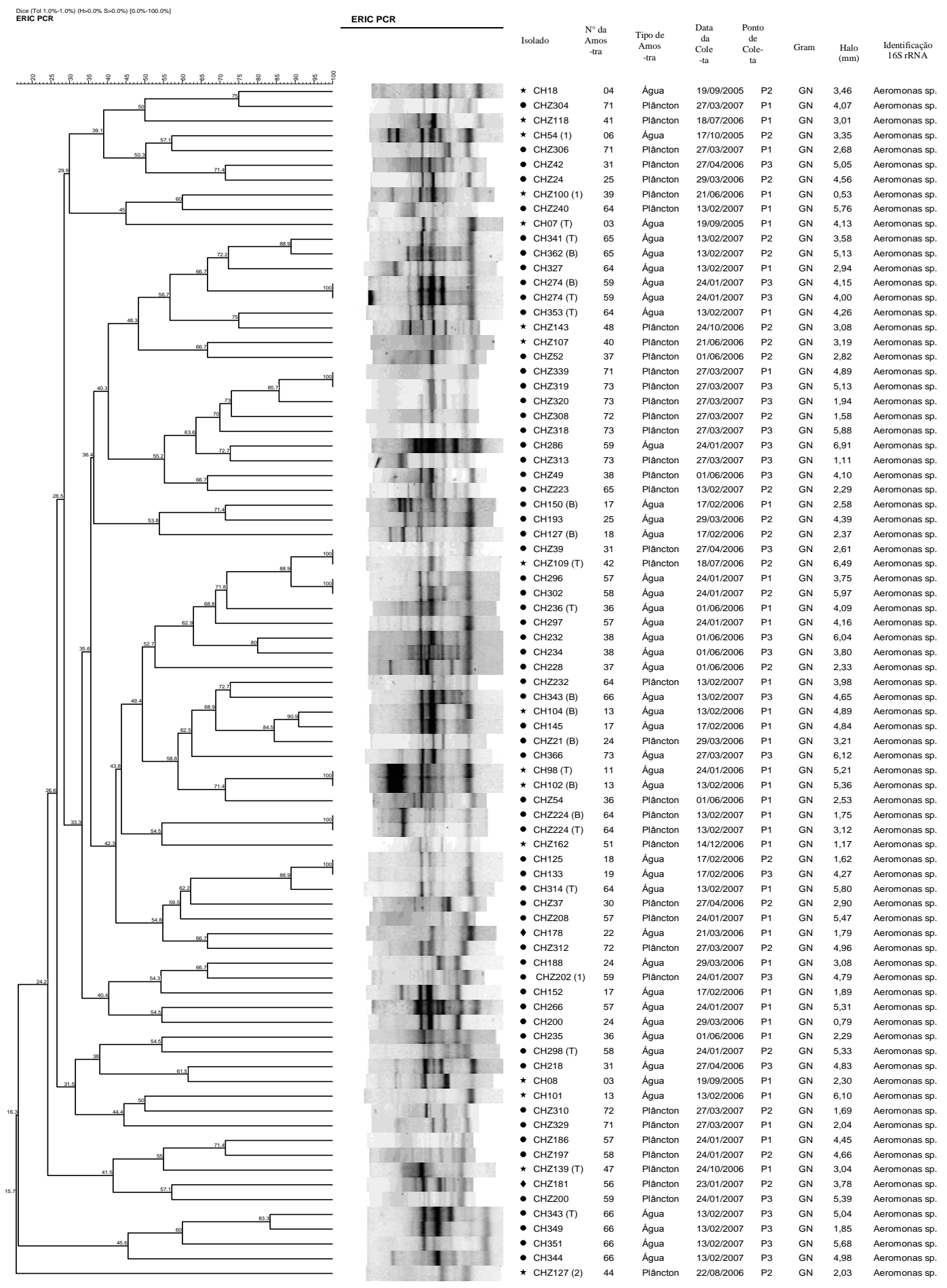

Figura 49 - Dendrograma construído com a técnica de ERIC-PCR com bactérias quitinolíticas identificadas como Aeromonas sp. pelo sequenciamento da região $16 \mathrm{~S}$ rRNA.

Legenda: GN - Gram-negativo; GP - Gram-positivo; •: Bactérias isoladas na Baixada Santista; *: Bactérias isoladas no Canal de São Sebastião; $\bullet$ : Bactérias isoladas em Ubatuba. 


\section{DISCUSSÃO DOS RESULTADOS}

\subsection{PAdRonizaÇÃo do MEIO de CULTURA PARA O CRESCIMENTO DE BACTÉRIAS QUITINOLÍTICAS}

\subsubsection{Seleção do método de obtenção de quitina coloidal e preparação de Meio Mínimo (MM)}

O sucesso no isolamento de bactérias quitinolíticas em laboratório, a partir de amostras ambientais, depende do meio de cultura que é utilizado, o qual deve apresentar uma constituição química semelhante à do ecossistema a ser estudado e apenas quitina como fonte de carbono. Porém, a quitina bruta é insolúvel em água, o que dificulta a sua utilização em meios de cultura. Sendo assim, vários pesquisadores recomendaram o uso de quitina coloidal em estudos de cultivo de microrganismos quitinolíticos, visto que esse tipo de quitina é mais solúvel em água (AKUTSU et al., 1993; AVELIZAPA et al., 1999; SKUJINS et al., 1965; HOWARD, M. B., 2003).

No decorrer dos anos, vários métodos de preparação de quitina coloidal foram descritos, os quais apresentam diferenças nos reagentes utilizados, na forma de preparação e na qualidade da quitina coloidal obtida (HIRANO e NAGAO, 1988; RAMÍREZ et al., 2004; ROBERTS e SELITRENNIKOFF, 1988; RODRIGUEZ-KABANA et al., 1983; SKUJINS et al., 1965; WEN et al., 2002; YABUKI et al., 1986). Diante disso, foi necessário selecionar nesse trabalho metodologias que apresentassem baixo custo de produção, rapidez na preparação e eficiência no isolamento de bactérias quitinolíticas. Além disso, foi selecionada a quitina de caranguejo, que é uma $\alpha$-quitina, pois de acordo com trabalhos de Carlstrom (1957) é o tipo de quitina mais abundante no ambiente marinho.

Comparando as metodologias testadas, foi verificado que a quitina coloidal obtida pelo método 1, proposto por Skujins et al. (1965) apresentou melhores resultados em comparação com os outros dois métodos testados (Método 2 - WEN et al., 2002; Método 3 - YABUKI et $a l$. , 1986), tanto em relação à facilidade e rapidez de preparação, quanto à qualidade da quitina coloidal obtida. Apesar de existir poucas diferenças entre os métodos 1 e 2 em relação aos reagentes utilizados, a quitina coloidal formada pelo método 1 apresentou qualidade superior em relação à quitina obtida pelo método 2, visto que as partículas não dissolvidas presentes na quitina coloidal preparada pelo Método 2 não foram visualizadas na quitina 
coloidal preparada de acordo com a metodologia 1. Em relação ao método 3, mesmo após os três dias de preparação não foi obtido quitina coloidal.

A utilização de meios de cultura contendo sais minerais e apenas quitina como fonte de carbono é uma das metodologias mais usadas para o isolamento e estudo de bactérias que degradam quitina, visto que as enzimas quitinolíticas produzidas por essas bactérias são capazes de se difundir no meio de cultura formando um halo ao redor das colônias o que possibilita a fácil identificação dessas bactérias (HOWARD, M. B., 2003). O halo foi observado ao redor das colônias bacterianas que cresceram nos dois meios de cultura utilizados nesse trabalho, MMQ1 e MMQ2. No entanto, o MMQ1 possibilitou visualizar melhor o halo e ainda isolar um maior número de bactérias quitinolíticas provenientes das amostras de água do mar e plâncton devido a sua característica semi-transparente com ausência de partículas sólidas de quitina.

Substratos como Remazol Brilliant Blue RR (CC-RBB) (Sigma-Aldrich), Fluorescent Calcofluor White M2R (Sigma-Aldrich) e Ranipal (Indian Dyestuff Industries) podem ser adicionados juntamente com a quitina coloidal ao meio de cultura para facilitar a visualização das zonas claras ao redor das colônias (ANIL et al., 2007; RAMÍREZ et al., 2004). Porém, mesmo sem a adição desses substratos, foi possível visualizar com facilidade o halo produzido pelas bactérias quitinolíticas obtidas de amostras de água do mar e plâncton e também pelas cepas padrão da família Vibrionaceae que cresceram no MMQ1.

Com isso o MMQ1 proposto nesse trabalho apresentou várias vantagens em comparação com outros meios descritos na literatura (ANIL et al., 2007; RAMÍREZ et al., 2004; VELASQUEZ e HAMMERSCHMIDT, 2004) como, por exemplo, o tempo reduzido de preparação da quitina coloidal, a eficiência no isolamento de bactérias quitinolíticas provenientes de amostras de água do mar e plâncton, a facilidade de visualização dos halos produzidos pelas bactérias e o baixo custo de preparação do meio.

\subsection{CARACTERIZAÇÃo FÍSICO-QUíMICA E MICROBIOLÓGICA DOS TRÊS ECOSSISTEMAS MARINHOS ESTUDADOS}

\subsubsection{Parâmetros Físico-químicos}

O litoral do estado de São Paulo sofre influência de três tipos de massas de água (Água Costeira - AC, Água Tropical - AT, e Água Central do Atlântico Sul - ACAS), as quais 
influenciam os níveis de salinidade e temperatura da água. No entanto, em relação às massas de água superficiais, estas possuem características termohalinas estreitamente relacionadas com a radiação solar, temperatura do ar e com o índice de pluviosidade da região (CASTRO FILHO et al., 1987; CASTRO FILHO, 1990).

A salinidade da água do mar é de aproximadamente 35\%o podendo sofrer alterações devido ao aporte de água doce e condições de temperaturas elevadas que podem ocasionar forte evaporação. Entretanto, nas imediações dos grandes estuários, a salinidade tende a ser mais baixa (MENDES, 1984). Esse fato foi observado nas amostras coletadas na Baía de Santos, onde os valores de salinidade variaram de 19,7 a 31,8 \%, sendo que todos os valores acima de 31\% foram encontrados no Ponto 2, que é o ponto mais próximo da saída da baía. No Canal de São Sebastião, durante os vinte meses de coleta de amostras a salinidade variou de 34 a 35\%, enquanto que em Ubatuba, os valores de salinidade variaram de 26,4 a 31,7 \%o com valores abaixo de 30\% sendo encontrados apenas nas amostras coletadas no ano de 2007.

As diferenças encontradas nos valores de salinidade da água do mar entre os locais estudados podem ser explicadas levando em consideração o índice de pluviosidade de cada região. A Baixada Santista, por exemplo, possui a maior média pluviométrica do litoral, tanto nos meses de primavera-verão, quanto nos meses de outono-inverno, o que aumenta o aporte de água doce dentro da Baía. E, em contrapartida, o município de São Sebastião apresenta os menores índices pluviométricos do litoral norte (COMPANHIA DE TECNOLOGIA DE SANEAMENTO AMBIENTAL, 2008).

Em regiões subtropicais, precipitações intensas podem ocorrer devido às mudanças nas condições meteorológicas associadas à passagem de frentes frias que acontecem durante todo o ano (MAHIQUES, 1995), fato esse que poderia explicar os baixos valores de salinidade encontrados em Ubatuba no ano de 2007.

A variação de temperatura observada nas amostras de água do mar coletadas na Baixada Santista $\left(19,6\right.$ a $\left.28,5^{\circ} \mathrm{C}\right)$, Canal de São Sebastião $\left(21,5\right.$ a $\left.26,3{ }^{\circ} \mathrm{C}\right)$ e Ubatuba $(25,3$ a $31,9^{\circ} \mathrm{C}$ ) durante os meses de amostragem realizados nesse estudo foi similar aos resultados encontrados em outros trabalhos de pesquisa. Na Baixada Santista foi observada temperatura da água do mar variando de 20,2 a 28,2 ${ }^{\circ} \mathrm{C}$ entre os meses de novembro de 2004 e dezembro de 2005 (ANCONA, 2007). Venturini, (2007) encontrou valores de temperatura da água do mar, variando de 23,2 a $27,2{ }^{\circ} \mathrm{C}$ nos meses de abril e novembro de 2004 no Canal de São 
Sebastião. Em Ubatuba, no período de setembro de 1995 a agosto de 1996, a temperatura da água do mar variou de 17,3 a $29,5^{\circ} \mathrm{C}$ (MANTELATTO e FRANSOZO, 1999).

Analisando a variação de temperatura e salinidade nos três ambientes estudados, não é possível afirmar que os nossos resultados foram influenciados pelas massas de água (AC, AT, ACAS), visto que a profundidade de coleta das amostras foi de apenas $10 \mathrm{~cm}$, sugerindo assim, que os valores obtidos podem ter sido influenciados pela radiação solar e pela temperatura do ar no dia das coletas de amostras.

Os valores de $\mathrm{pH}$ da água do mar dos três locais estudados, estiveram dentro de uma faixa normalmente encontrada em águas estuarinas e oceânicas. $\mathrm{O}$ valor mais baixo $(6,5)$ foi encontrado no Ponto 3 da Baixada Santista, local onde existe a predominância de contaminação industrial proveniente da região de Cubatão. Os demais valores de pH variaram de 7,0 a 8,5 com o maior valor sendo encontrado no Canal de São Sebastião.

Em relação à condutividade, o valor mais baixo $(31,8 \mathrm{~ms})$ também foi encontrado na Baixada Santista, no mesmo dia e no mesmo ponto (Ponto 1) onde foram encontrados os valores mais baixos de salinidade $\left(19,7 \%\right.$ o) e temperatura $\left(19,6{ }^{\circ} \mathrm{C}\right)$. Os demais valores de condutividade variaram de 37,6 a $49,9 \mathrm{~ms}$, sendo que o maior valor foi observado em Ubatuba.

\subsubsection{Parâmetros microbiológicos - Indicadores de Contaminação fecal}

A crescente ocupação das regiões costeiras e a formação de grandes centros urbanos costeiros trouxeram a necessidade de uma avaliação contínua da qualidade das águas litorâneas. A descarga de esgotos não tratados afeta a saúde do ecossistema marinho em duas formas: (1) poluição microbiana pela introdução de microrganismos patogênicos levados pelo homem, os quais podem afetar a saúde humana e (2) os poluentes químicos, orgânicos e inorgânicos, que podem afetar severamente as estruturas das comunidades dos ecossistemas (RIVERA et al., 2008).

Nas cidades litorâneas do estado de São Paulo, a poluição não atinge igualmente os municípios litorâneos paulistas, ela é regionalizada, variando de acordo com as atividades econômicas predominantes. O Litoral Norte é afetado principalmente pela falta de saneamento básico, responsável pela poluição dos cursos d‘água locais e pela disposição de resíduos sólidos. Derrames significativos de óleo afetam principalmente a região próxima ao Canal de São Sebastião. O Litoral Sul é o menos afetado por poluição, mas também sofre com 
a falta de saneamento e disposição adequada dos resíduos sólidos. A região mais crítica é a Baixada Santista que, além do saneamento básico insuficiente, em alguns municípios, abriga o maior porto da América Latina e um expressivo complexo industrial (CETESB, 2004). Indicadores microbiológicos como os Coliformes Termotolerantes, E. coli e Enterococos intestinais, têm sido utilizados mundialmente para verificar a contaminação fecal dos corpos d'água, indicando assim a presença de bactérias patogênicas, que são uma ameaça à saúde pública e ambiental (von SPERLING, 1996; SHIBATA et al., 2004).

Segundo os critérios estabelecidos na Resolução CONAMA no 274/2000, densidades de Coliformes Termotolerantes, E. coli e Enterococos Intestinais superiores a 1000 UFC/100 $\mathrm{mL}, 800 \mathrm{UFC} / 100 \mathrm{~mL}$ e $100 \mathrm{UFC} / 100 \mathrm{~mL}$, respectivamente, em duas ou mais amostras de um conjunto de cinco semanas, caracterizam a impropriedade de uma praia para recreação de contato primário (balneabilidade). Apesar das coletas de amostras nesse trabalho não terem sido feitas semanalmente e sim mensalmente, os resultados das amostras foram avaliados como indicativas de contaminação pontual.

As amostras de água coletadas no Canal de São Sebastião e Ubatuba apresentaram contagens de Coliformes Termotolerantes, E. coli e Enterococos Intestinais abaixo dos valores estabelecidos pela Resolução CONAMA n 274/2000 para atividades de recreação de contato primário, mostrando assim que o nível de impacto antropogênico é baixo nesses dois locais, o que é confirmado ao comparar os resultados obtidos nesse trabalho com dados de balneabilidade da CETESB, que mostrou que as praias próximas aos nossos pontos de coleta permaneceram próprias para atividades de recreação primária durante todo o ano de 2006 e 2007 (CETESB, 2008).

Na Baixada Santista, nos pontos 01 e 03 foram encontradas as maiores contagens dos indicadores de contaminação fecal, em comparação com os outros dois ambientes estudados. Principalmente nos meses de fevereiro e março de 2006, onde as contagens de Coliformes Termotolerantes, E. coli e Enterococos intestinais chegaram a 8,4 x $10^{3} \mathrm{UFC} / 100 \mathrm{~mL}, 9,1 \mathrm{x}$ $10^{2} \mathrm{UFC} / 100 \mathrm{~mL}$ e $4,9 \times 10^{1} \mathrm{UFC} / 100 \mathrm{~mL}$, respectivamente, ficando acima dos valores estabelecidos pela Resolução CONAMA no 274/2000. Dados da CETESB mostraram que em 2006 e 2007, 54\% e 60\%, respectivamente, das praias de Santos tiveram classificação anual "Ruim" para balneabilidade, demonstrando assim, o alto índice de contaminação da região de Santos (CETESB, 2008). Em todas as amostras de água $(n=7)$, coletadas no Ponto 02 da Baixada Santista, os valores encontrados para os indicadores de contaminação fecal 
analisados ficaram abaixo dos valores estabelecidos pela Resolução CONAMA nº 274/2000, indicando que esse local apresenta menores índices de impacto antropogênico.

A poluição presente na Baixada Santista, causada principalmente pelo porto de Santos, pelas indústrias da região de Cubatão e pelos esgotos domésticos liberados, tanto no estuário, quanto através do emissário submarino, é responsável pelos altos valores de Coliformes Termotolerantes, E. coli e Enterococos intestinais encontrados nesse estudo em comparação com os valores encontrados em amostras de água do mar do Canal de São Sebastião e Ubatuba.

A partir dos resultados obtidos nesse trabalho em relação às contagens de Coliformes Termotolerantes, Escherichia coli, enterococos intestinais e análises estatísticas foi possível classificar a Baixada Santista, o Canal de São Sebastião e Ubatuba como ambientes de alto, médio e baixo impacto antropogênico, respectivamente.

\subsubsection{Contagem de bactérias quitinolíticas viáveis}

Nos últimos anos, as bactérias quitinolíticas foram isoladas nos mais variados ambientes, incluindo solos, campos de pastagens, lagos, estuários, oceanos e sedimentos de lago da Antártica. Entretanto, a maioria desses trabalhos tem como enfoque o estudo de um microrganismo específico ou a avaliação da diversidade de genes de quitinase de microrganismos não cultiváveis (WILLIAMSON et al., 2000; KRSEK e WELLINGTON, 2001; METCALFE et al., 2002; TSUJIBO et al., 2003; LECLEIR et al., 2007). Com isso, estudos ecológicos mostrando a diversidade de bactérias quitinolíticas cultiváveis presentes em um determinado tipo de amostra e ainda relacionando-as com fatores bióticos e abióticos são relativamente raros.

Além disso, a maioria dos trabalhos sobre bactérias quitinolíticas no ambiente marinho têm sido realizados em países de clima frio e temperado (HIRONO et al., 1998; HOWARD, M. B., 2003; ITOI et al., 2007; LI e ROSEMAN, 2004; ORIKOSHI et al., 2005). Portanto, na tentativa de conhecer a diversidade de bactérias quitinolíticas no ecossistema marinho de um país de clima tropical, nesse trabalho foram isoladas bactérias quitinolíticas em amostras de água do mar e plâncton em três locais do litoral do estado de São Paulo, cuja diferença marcante entre eles era o nível de contaminação fecal.

As bactérias quitinolíticas foram encontradas em baixa concentração na coluna d'água, principalmente no Canal de São Sebastião $\left(<1\right.$ a $\left.1,9 \times 10^{1} \mathrm{UFC} / \mathrm{mL}\right)$ e Ubatuba $\left(<1\right.$ a $2,0 \times 10^{0}$ 
UFC/mL) em comparação com as amostras de plâncton dos mesmos locais, que chegaram a atingir contagens de $9,1 \times 10^{3} \mathrm{UFC} / \mathrm{g}$ no Canal de São Sebastião e $2,8 \times 10^{3} \mathrm{UFC} / \mathrm{g}$ em Ubatuba. Na Baixada Santista, as contagens obtidas em amostras de água foram maiores (4,0 a 2,2 $\times 10^{2} \mathrm{UFC} / \mathrm{mL}$ ) do que as contagens encontradas no Canal de São Sebastião e Ubatuba. Mesmo assim, ainda apresentaram duas ordens de magnitude abaixo das contagens obtidas em amostras de plâncton $\left(2,0 \times 10^{2}\right.$ a 4,4 x $\left.10^{4} \mathrm{UFC} / \mathrm{g}\right)$.

No Canal de São Sebastião, as diferenças nas contagens de bactérias quitinolíticas entre os dois pontos de coleta, tanto em amostras de água do mar como em amostras de plâncton não foram consideradas estatisticamente significantes, possivelmente devido à distância entre os dois pontos, visto que ambos são localizados dentro do Canal, sofrendo assim, o mesmo tipo de influência ambiental, como correntes marítimas, ventos e umidade. Em Ubatuba, a distância entre os dois pontos de coleta também pode ter sido o fator determinante para que eles fossem considerados estatisticamente semelhantes em relação às contagens de bactérias quitinolíticas obtidas nas amostras de água do mar e plâncton.

As contagens de bactérias quitinolíticas em amostras de água do mar e plâncton coletadas no Canal de São Sebastião não apresentaram variação temporal definida. Esse fato pôde ser facilmente observado nas contagens realizadas em amostras de água obtidas no mês de novembro de 2005 e novembro de 2006, onde foi encontrada uma média de $<1 \mathrm{UFC} / \mathrm{mL}$ e $10 \mathrm{UFC} / \mathrm{mL}$, respectivamente. Em janeiro de 2006, foi encontrada uma média de $13 \mathrm{UFC} / \mathrm{mL}$ de bactérias quitinolíticas em amostras de água do mar, enquanto que em janeiro de 2007 a média foi de $4 \mathrm{UFC} / \mathrm{mL}$.

Apesar de países de clima tropical, não apresentarem estações bem definidas, nos meses de outono e inverno (abril/2006 a setembro/2006), as contagens de bactérias em amostras de água do Canal de São Sebastião não ultrapassaram $1 \mathrm{UFC} / \mathrm{mL}$, enquanto que nos meses de verão as contagens de bactérias quitinolíticas foram mais altas, variando em média de 4 a 12 UFC/mL. Mas vale ressaltar que, também foram encontradas <1 UFC/mL no verão de 2007 (Março/2007).

$\mathrm{O}$ aumento do número de bactérias quitinolíticas foi relacionado com a presença de corrente marítima superficial sul e ventos vindos do sul, o que pode explicar as baixas contagens de bactérias quitinolíticas encontradas nos meses de outono e inverno onde esses dois fatores climáticos estavam ausentes nos dias de coleta de amostras. Outro fator que também influenciou na concentração de bactérias quitinolíticas foi a presença de céu nublado nos dias de coleta. Porém, a ausência dos dados de precipitação pluviométrica no Canal de 
São Sebastião impossibilitou relacionar esse fator com a presença de chuva, a qual poderia ter carregado material particulado para o oceano, aumentando assim, o número de bactérias quitinolíticas.

Em amostras de plâncton, as maiores contagens de bactérias quitinolíticas foram encontradas em meses do outono de 2006 (abril e maio), mas em seguida, nos meses de inverno, houve queda nas contagens dessas bactérias. É importante lembrar que em amostras de plâncton foram encontradas altas contagens de $\mathrm{CSH}$ as quais podem ter prejudicado visualização das contagens de bactérias quitinolíticas.

Em Ubatuba, as contagens de bactérias quitinolíticas em amostras de água do mar foram muito baixas, apesar de ter apresentado diferenças estatisticamente significantes somente com as contagens encontradas na Baixada Santista. Entretanto, em amostras de plâncton, as contagens de bactérias quitinolíticas atingiram valores mais elevados, mas mesmo assim foram consideradas estatisticamente diferentes das contagens encontradas nos outros dois locais de coleta.

A associação de bactérias a organismos vivos aumenta a sobrevivência dessas bactérias em situações de estresse ambiental, como por exemplo, ambientes oligotróficos, como é o caso de Ubatuba, podendo assim explicar as diferenças encontradas nas contagens de bactérias quitinolíticas em amostras de água do mar e plâncton provenientes dessa região. Fatores climáticos e valores de nutrientes, por exemplo, poderiam também ajudar a explicar as baixas contagens de bactérias quitinolíticas em amostras de água do mar. Porém, esse tipo de informação não foi obtida para o período de coletas de amostras realizadas em Ubatuba.

Dentre os três ambientes estudados, a Baixada Santista é o ambiente mais complexo, devido à quantidade de substâncias orgânicas e inorgânicas provenientes das descargas de esgotos domésticos e industriais lançados in natura nas águas costeiras, disposição de resíduos sólidos às margens dos canais estuarinos ou em áreas de mangue e das atividades portuárias, entre elas a dragagem dos canais de navegação, que aumenta a turbidez das águas pela ressuspensão de sedimento. Sendo assim, essas inúmeras substâncias presentes no estuário, influenciaram de forma significativa nas contagens de bactérias quitinolíticas, visto que nesse ambiente foram obtidas as maiores contagens dessas bactérias, em comparação com o Canal de São Sebastião e Ubatuba que são locais com médio e baixo nível de atividade antropogênica.

Apesar dos três pontos de coleta estarem localizados dentro da Baía de Santos, através das análises estatísticas, o ponto 2 foi considerado estatisticamente diferente dos demais em 
relação às contagens de bactérias quitinolíticas em amostras de água, apresentando as menores contagens em relação aos outros dois pontos. Possivelmente, essa diferença se deve à proximidade do ponto 2 com o oceano aberto, onde os níveis de contaminação são menores. No entanto, dados climáticos e valores de nutrientes poderiam ajudar a explicar as diferenças de contagens de bactérias quitinolíticas entre os pontos de coleta localizados na Baixada Santista, porém esse tipo de informação não foi encontrada. Em contrapartida, em relação às contagens de bactérias quitinolíticas em amostras de plâncton, os três pontos de coleta foram considerados estatisticamente semelhantes.

Como as coletas de amostras de água do mar e plâncton de Ubatuba e da Baixada Santista foram realizadas apenas nos meses de fevereiro a maio de 2006 e janeiro a março de 2007, não foi possível verificar a distribuição temporal dessas bactérias, devido ao número reduzido de amostras coletadas.

Ao compararmos os resultados obtidos nesse estudo com outros trabalhos publicados, verificamos que as contagens de bactérias quitinolíticas encontradas na coluna d'água em ambientes de clima temperado e frio também são baixas, como pôde ser observado no trabalho de Seki e Taga (1963), onde relataram que a contagem de bactérias quitinolíticas em Sagami Bay, no Japão, variaram de $<1$ a 5,0 x $10^{3} \mathrm{UFC} / \mathrm{mL}$ e Herwig et al. (1988) não encontraram bactérias quitinolíticas em águas marinhas da Antártica $(<1 \mathrm{UFC} / \mathrm{mL})$.

Estudos de contagens de bactérias quitinolíticas em amostras de plâncton não foram encontrados até o momento. Entretanto, alguns trabalhos têm mostrado a associação de bactérias ao zooplâncton, em especial aos copépodes (HUQ et al., 1983; HUQ et al., 1990; HEIDELBERG et al., 2002), à cianobactérias (ISLAM et al., 1999) e à algas (ISLAM, 1990), mas não informam qual é o número dessas bactérias que são capazes de hidrolisar quitina.

A maioria dos trabalhos que mostram a atividade quitinolítica de bactérias isoladas de amostras ambientais realiza primeiramente o isolamento de bactérias heterotróficas em meios de cultura com ausência de quitina e, após isso, as bactérias isoladas são testadas quanto à capacidade de formar zonas claras (halos) em meio mínimo contendo quitina como única fonte de carbono. Dessa forma, foi verificado que 54\% das bactérias heterotróficas isoladas em amostras de água do mar no estuário de Delaware Bay, EUA apresentaram atividade quitinolítica em meio de cultura contendo quitina coloidal (COTTRELL et al., 2000). Em amostras de água superficiais do Lago Gardno na Itália, Mudryk (2004) verificou que 10,6\% das bactérias isoladas conseguiram degradar quitina. 
Ramaiah et al. (2000), ao testarem mais de 1000 bactérias heterotróficas quanto a presença do gene chiA, que codifica para a produção da quitinase A que é a principal responsável pelo início do processo de degradação de quitina, verificaram que a porcentagem de bactérias quitinolíticas em amostras de água coletadas em Chesapeake Bay, EUA foi de $21 \%$. Cinco dos isolados que foram positivos para a presença do gene chiA, também foram inoculados em caldo contendo quitina sem tratamento e a capacidade de degradar quitina pôde ser comprovada após 35 dias de incubação.

Em amostras de carapaça de caranguejo, Chen e Chen (1991) verificaram que apenas 2,7\% do total de bactérias heterotróficas isoladas apresentaram atividade quitinolítica em meio de cultura contendo quitina coloidal. Brzezinska et al. (2008) verificaram que, em média, o número de bactérias heterotróficas no exoesqueleto fresco de camarão obtido de indústria de processamento de alimentos era de $1,05 \times 10^{5} \mathrm{UFC} / \mathrm{g}$ e o número de bactérias quitinolíticas correspondia a $4 \%$ desse total ao realizar contagens em placas contendo quitina como fonte de carbono.

Dados de contagem total de bactérias mostram que em oceano aberto, a comunidade dominante na coluna d'água são as bactérias livres, principalmente porque poucas partículas estão presentes nesse local (DeLONG et al., 1993; UNANUE et al., 1992). Em contrapartida, em ambientes de água doce, costeira e estuarina, onde as partículas são mais abundantes, os microrganismos associados a partículas estão presentes em maiores concentrações (KIRCHMAN e MITCHELL, 1982; BIDLE e FLECHER, 1995), explicando assim as maiores contagens em amostras de água do mar coletadas na Baía de Santos e em amostras de plâncton dos três locais.

É importante ressaltar ainda, que os indicadores de contaminação fecal também podem ser utilizados para explicar as maiores contagens de bactérias quitinolíticas na Baixada Santista, visto que nesse trabalho foi encontrada uma forte correlação entre coliformes termotolerantes e uma correlação moderada entre bactérias quitinolíticas e Escherichia coli. Apesar de fraca, também foi observada correlação, entre coliformes termotolerantes e bactérias quitinolíticas no Canal de São Sebastião.

Após analisar as contagens de bactérias que cresceram em MMQ1, mas não apresentaram halo de hidrólise (CSH), verificou-se que no Canal de São Sebastião e Ubatuba, as contagens em amostras de água apresentaram três ordens de magnitude abaixo das contagens obtidas em amostras de água da Baía de Santos. E, ao comparar as contagens de bactérias quitinolíticas com as CSH em amostras de água dos três ambientes, foi verificado 
que as bactérias quitinolíticas, correspondem a 12\% do total de contagens de bactérias que não apresentaram halo e em amostras de plâncton essa porcentagem é de 4\%. No entanto, algumas bactérias que crescem em placas contendo quitina, às vezes não são capazes de formar halo de hidrólise, mas em meio líquido expressam a enzima quitinase (NEUGEBAUER et al., 1990).

Entretanto, mesmo tendo observado que a contagem de bactérias quitinolíticas foi mais baixa em relação às CSH, foram isoladas apenas aquelas que apresentaram halo para dar continuidade aos estudos de diversidade de bactérias e expressão da enzima quitinase, visto que em processos biotecnológicos há um maior interesse em microrganismos que expressam enzimas extracelulares.

\subsection{CARACTERIZAÇÃO FENOTÍPICA DAS BACTÉRIAS QUITINOLÍTICAS}

\subsubsection{Reisolamento e determinação do tempo de incubação para formação de halo de hidrólise de quitina}

Atualmente, as descobertas em microbiologia ambiental têm, cada vez mais, contribuído com o desenvolvimento da biotecnologia, visto que o sucesso dos processos biotecnológicos está diretamente relacionado com a diversidade dos microrganismos e das moléculas que eles produzem como resultado do metabolismo primário e secundário, bem como com a conservação dos recursos genéticos que eles fornecem. Com isso, a otimização da capacidade microbiana para a fertilização dos solos e despoluição das águas, a descoberta de novos antibióticos e agentes terapêuticos, enzimas, probióticos e produtos químicos são apenas alguns exemplos dos benefícios obtidos com a descoberta de microrganismos potencialmente exploráveis em processos biotecnológicos (BULL et al., 1998). Nesse sentido, o presente trabalho associou a microbiologia ambiental e a biotecnologia ao isolar 492 bactérias quitinolíticas em três locais do litoral do estado de São Paulo e estudar a diversidade dessas bactérias e o seu potencial enzimático.

Suginta et al. (2000) analisaram a formação de halo de hidrólise de quitina produzidos por 14 espécies de Vibrio e verificou a formação de halo após 72 horas de incubação a $30^{\circ} \mathrm{C}$ em placas de meio marinho contendo $1 \%$ de quitina umedecida. Em outro trabalho de detecção de quitinase em espécies de Vibrio, Bhowmick et al. (2007) detectaram a presença de halo de hidrólise em placas de meio mínimo M9 contendo $1 \%$ de quitina coloidal após 72 
horas de incubação a $30{ }^{\circ} \mathrm{C}$. Em contrapartida, no presente trabalho foi verificado que $80 \%$ das bactérias quitinolíticas isoladas, incluindo as bactérias gram-negativas e gram-positvas (bacilos, cocos e filamentosas), apresentaram halo de hidrólise de quitina dentro de 72 horas de incubação em meio mínimo contendo quitina coloidal.

Setenta cepas de Bacillus thuringiensis foram testadas quanto à atividade quitinolítica em placas de ágar mínimo contendo $10 \%$ de quitina coloidal com 72 horas de incubação a $30{ }^{\circ} \mathrm{C}$ e verificaram que $58 \%$ delas formaram halo de degradação de quitina em meio sólido (LIU et al. 2002). Hoster et al. (2005) isolaram 33 diferentes bactérias degradadoras de quitina pertencentes aos gêneros Bacillus e Streptomyces em amostras de solo e sedimento marinho e verificaram que os isolados apresentaram halo de hidrólise de quitina no período de 24 a 96 horas a $30{ }^{\circ} \mathrm{C}$, em meio mínimo contendo $0,7 \%$ de quitina coloidal.

No ambiente marinho, 90\% das bactérias são gram-negativas (DAS et al., 2006; ZOBELL, 1946) e de acordo com Giovannoni e Rappé (2000), $\gamma$-proteobacteria são amplamente distribuídas no oceano, enquanto que bactérias gram-positivas são raras na água do mar explicando assim, o maior percentual de bactérias gram-negativas obtidas nesse trabalho, visto que nos três locais de coleta de amostras, Canal de São Sebastião, Baixada Santista e Ubatuba e nos dois tipos de amostras: água do mar e plâncton, o número de gramnegativos superou o número de gram-positivos, exceto nas amostras de água do mar de Ubatuba. Entretanto, vale ressaltar que o número de bactérias obtidas em amostras de água de Ubatuba foi muito baixo (10 bactérias).

DeLong e Karl (2005) afirmaram que os actinomicetos são facilmente isolados do ambiente marinho, o que pôde ser claramente observado nesse estudo, onde o número de gram-positivos filamentosos, coletados no Canal de São Sebastião, atingiu 39\% ( $\mathrm{n}=84)$ e $37,0 \%(n=115)$ dos isolados de amostras de água e plâncton, respectivamente. Em amostras de água e plâncton de Ubatuba, a porcentagem de gram-positivos filamentosos foi de 90,0\% $(n=10)$ e 29,0\% $(n=41)$, respectivamente. Em Santos, as contagens de bactérias grampositivas filamentosas foram menores em comparação com os outros dois ambientes estudados, $21 \%(n=135)$ em amostras de água do mar e 9,0\% (n=107) em amostras de plâncton. Porém, o número reduzido de gram-positivos filamentosos nessas amostras pode ser explicado pelos valores elevados de bactérias gram-negativas que cresceram nas placas contendo MMQ1, o que dificultou o isolamento dos actinomicetos.

Todavia, durante muitos anos, os actinomicetos encontrados nos oceanos foram considerados de origem terrestre, mas com o avanço das pesquisas em biologia molecular foi 
comprovado que actinomicetos ocorrerem naturalmente no ecossistema marinho (BULL et al., 2005; DeLONG e KARL, 2005; MORAN et al., 1995; URAKAWA et al., 1999) e entre os microrganismos, os actinomicetos têm se destacado devido a capacidade de produzir metabólitos secundários bioativos e enzimas. Os actinomicetos marinhos constituem uma importante fonte de novos compostos bioativos sendo capazes de produzir inúmeros antibióticos, os quais são totalmente diferentes dos antibióticos produzidos por actinomicetos de origem terrestre (JENSEN e FENICAL, 1994; JENSEN e FENICAL, 1996; KOKARE et al., 2004).

A partir do próximo item (6.3.2.) os resultados de atividade enzimática e rep-PCR serão discutidos juntamente com os resultados do sequenciamento parcial da região $16 \mathrm{~S}$ rRNA das bactérias quitinolíticas com o objetivo de facilitar a discussão e comparar os resultados obtidos nesse trabalho com outros trabalhos publicados.

\subsubsection{Avaliação da degradação de quitina em meio sólido}

A medida do diâmetro do halo de hidrólise de quitina produzido pelas 492 bactérias quitinolíticas semeadas em MMQ1 foi utilizado para avaliar o potencial de produção de quitinases de cada isolado. O halo das bactérias quitinolíticas gram-negativas e gram-positivas foi medido com 96 horas de incubação e das bactérias gram-positivas filamentosas a medida foi realizada com 168 horas de incubação.

Analisando a capacidade de degradação de quitina, de acordo com o local de coleta, foi verificado que as bactérias quitinolíticas gram-negativas e gram-positivas (bacilos e cocos) isoladas em ambiente com alto nível de atividade antropogênica (Baixada Santista) apresentaram os maiores valores de diâmetro do halo de hidrólise de quitina tanto em amostras de água do mar quanto em amostras de plâncton, demonstrando assim uma maior atividade quitinolítica. Esses resultados estão de acordo com outros estudos que demonstraram que a atividade enzimática de bactérias heterotróficas é significantemente maior em estuários em comparação com água doce e oceano (CUNHA et al., 2000; JACKSON et al., 1995; JORGENSEN et al., 1999; PATEL et al., 2000).

Comparando os valores do diâmetro do halo produzido apenas pelas bactérias quitinolíticas gram-negativas e gram-positivas (bacilos e cocos) isoladas da Baixada Santista, verificamos que os menores halos foram produzidos por bactérias provenientes de amostras 
de água do mar coletadas no Ponto 2, onde foi encontrada a menor contagem de indicadores de contaminação fecal. Todavia, não foram encontradas diferenças estatisticamente significantes entre os três pontos de coleta ao analisar o diâmetro do halo produzido pelas bactérias quitinolíticas gram-negativas e gram-positivas (bacilos e cocos) isoladas de amostras de plâncton e também das bactérias gram-positivas filamentosas provenientes tanto de amostras de água do mar como de plâncton. Mas é importante lembrar que o número de bactérias quitinolíticas gram-positivas filamentosas isoladas na Baixada Santista foi baixo.

As cepas padrão da família Vibrionaceae que foram selecionadas para serem utilizadas como controles positivos do meio de cultura apresentaram valores baixos de medida do diâmetro do halo de hidrólise de quitina (1,29 a 1,90 mm) em comparação com os isolados obtidos nesse estudo, onde $72 \%$ dos isolados que foram incubados por 96 horas apresentaram $>2,1 \mathrm{~mm}$ de diâmetro do halo.

Ao analisar o diâmetro do halo de hidrólise de quitina produzido pelas bactérias quitinolíticas, sem levar em consideração o local de coleta, verificamos que a porcentagem de isolados que apresentaram halo de hidrólise de quitina variando de 2 a $4 \mathrm{~mm}$ correspondeu a 49\% dos isolados que tiveram tempo de incubação de 96 horas. Liu e colaboradores (2002) verificaram que $25 \%$ de um total de 70 cepas de $B$. thuringiensis apresentaram halo de hidrólise de quitina com diâmetro variando de 2-4 mm com 72 horas de incubação a $30^{\circ} \mathrm{C}$ em placas de meio mínimo contendo $10 \%$ de quitina coloidal.

Frändberg e Schnürer (1994b) observaram que Bacillus pabuli K1 produziu um halo de 3,5 mm após 5 dias de incubação a $30{ }^{\circ} \mathrm{C}$ em meio mínimo contendo quitina coloidal. Em outro trabalho o diâmetro do halo de hidrólise de quitina produzido por quinze cepas pertencentes ao gênero Bacillus em meio Bushnell Haas-Chitin Agar (BHCH) após 96 horas de incubação a $30{ }^{\circ} \mathrm{C}$ variou de 1,0 a 2,0 mm (CODY, 1989). Em contrapartida, as dez bactérias quitinolíticas que foram identificadas como Bacillus sp. através do sequenciamento parcial do 16S rDNA nesse trabalho, produziram halos variando de 0,82 a 3,89 $\mathrm{mm}$ com 96 horas de incubação a $27^{\circ} \mathrm{C}$.

Donderski e Trzebiatowska (2000) isolaram oito gêneros diferentes de bactérias quitinolíticas em uma zona pelágica do Lago Jeziorak na Polônia e verificaram que Aeromonas sp., Erwinia stewartii, Vibrio fluvialis, Serratia sp., Bacillus pumilus e Bacillus firmus produziram, respectivamente, halos de hidrólise de quitina com 2, 2, 2, 2, 1 e 2 mm após 96 horas de incubação em meio mínimo contendo $0,5 \%$ de quitina coloidal. Porém, concluíram que as melhores degradadoras de quitina foram Serratia sp. e Erwinia stewartii, 
pois apresentaram halo de $9 \mathrm{~mm}$ após 288 horas de incubação. Entretanto, dentre os isolados identificados como Aeromonas sp. no presente trabalho, 24\% apresentaram halo de hidrólise variando de 5,1 a 6,91 mm de diâmetro no período de 96 horas de incubação.

É interessante ressaltar ainda, que no trabalho de Donderski e Trzebiatowska (2000), nenhuma das bactérias citadas acima apresentaram atividade quitinolítica antes de 48 horas de incubação, enquanto que nesse trabalho, $28 \%$ das bactérias quitinolíticas apresentaram halo em 24 horas de incubação a $27^{\circ} \mathrm{C} \pm 2{ }^{\circ} \mathrm{C}$.

Por outro lado, analisando o diâmetro do halo de hidrólise dos isolados identificados como Serratia sp. no atual trabalho, verificamos que elas mostraram halo de hidrólise de quitina variando de 1,78 a 4,96 mm de diâmetro com 96 horas de incubação. No entanto, a bactéria Serratia marcescens, que vem sendo utilizada em alguns estudos como controle positivo para detecção de quitinase em meio sólido, produz halo variando de 5 a $6 \mathrm{~mm}$ em meio sólido contendo quitina coloidal com incubação de 96 horas a $30{ }^{\circ} \mathrm{C}$ (AVELIZAPA et al., 1999; LIU et al., 2002). Mas é importante lembrar que, apesar da fonte de carbono ser a mesma nos trabalhos de degradação bacteriana de quitina, os meios de cultura apresentam diferenças em sua constituição química, dificultando a comparação do diâmetro do halo encontrado nesse trabalho com os resultados disponíveis nas publicações científicas

O diâmetro do halo de hidrólise de quitina das bactérias quitinolíticas filamentosas isoladas variou de $0,86 \mathrm{~mm}$ a $8,84 \mathrm{~mm}$ com 168 horas de incubação, apresentando assim um bom potencial de degradação de quitina, apesar do tempo de incubação de ter sido maior em comparação com as bactérias gram-negativas e gram-positivas (bacilos e cocos). Entretanto, além do potencial quitinolítico dos actinomicetos a capacidade de produzir inúmeros compostos bioativos tem cada vez mais atraído a atenção de vários pesquisadores. Pisano et al. (1992) isolaram 116 actinomicetos quitinolíticos de sedimento marinho e observaram que 85 (73\%) apresentaram atividade antimicrobiana, especialmente contra bactérias grampositivas e fungos. No mesmo trabalho, os autores encontraram uma alta correlação entre atividade quitinolítica e produção de compostos bioativos, sugerindo assim que a atividade quitinolítica pode ser utilizada como uma boa indicadora do potencial bioativo de actinomicetos de origem marinha.

A capacidade de degradar quitina coloidal presente em meios de cultura, tem sido extensivamente estudada no decorrer dos anos. Porém, a maioria dos trabalhos informa apenas que a bactéria estudada foi capaz de produzir grandes halos de hidrólise de quitina, sem citar o diâmetro de cada halo. Osawa e Koga (1995), por exemplo, isolaram um total de 
48 bactérias em amostras de água de rio e oceano e verificaram que todas foram capazes de formar halos em meio de cultura contendo quitina coloidal. Brzezinska e Donderski (2001) isolaram bactérias quitinolíticas de amostras de água de lago e verificaram que após 12 dias de incubação a $20^{\circ} \mathrm{C}$ foi possível realizar a medida de halos brilhantes que cresceram ao redor das colônias bacterianas, possibilitando verificar a habilidade das bactérias em degradar quitina em meio de cultura.

\subsubsection{Quantificação de atividade enzimática através da liberação de $N$-acetil-glicosamina (GlcNAc)}

O ensaio de quantificação da atividade enzimática através da liberação de GlcNAc foi realizado com as 492 bactérias quitinolíticas. A porcentagem de bactérias que apresentaram $>1 \mathrm{U}$ de enzima foi baixa, correspondendo a $22 \%$ das 358 bactérias quitinolíticas gramnegativas e gram-positivas (bacilos e cocos) e apenas 3\% das 134 bactérias quitinolíticas gram-positivas filamentosas.

Assim como foi observado na produção de halo de hidrólise de quitina, as bactérias quitinolíticas isoladas de amostras de água do mar e plâncton da Baixada Santista apresentaram os maiores valores de produção de enzimas, sendo que das 79 bactérias gramnegativas e gram-positivas (bacilos e cocos) que apresentaram $>1 \mathrm{U}$ de enzima, 66 foram isoladas de amostras coletadas na Baixada Santista. E ainda: as bactérias isoladas dos pontos 1 e 3, onde foram encontrados os maiores níveis de contaminação fecal, produziram níveis de enzimas significantemente maiores do que aquelas isoladas do ponto 2. Confirmando, novamente, que a atividade enzimática em estuários é significantemente maior em comparação com outros ecossistemas aquáticos (CUNHA et al., 2000; JACKSON et al., 1995; JORGENSEN et al., 1999; PATEL et al., 2000).

Em amostras de plâncton provenientes dos três locais estudados, o número de bactérias quitinolíticas que não apresentaram atividade enzimática foi sempre maior em comparação com as bactérias quitinolíticas isoladas de amostras de água do mar. Todavia, era esperado que fosse encontrado o contrário, visto que bactérias associadas a partículas ou a outros organismos são geralmente maiores e mais ativas metabolicamente (DeLong et al., 1993).

As bactérias quitinolíticas gram-negativas apresentaram a maior atividade enzimática em comparação com as bactérias gram-positivas (bacilos e cocos) e gram-positivas 
filamentosas. Contudo, vários trabalhos têm mostrado o potencial de degradação de quitina de várias espécies de Aeromonas (LAN et al., 2004; PEMBERTON, et al., 1997; SASHIWA et al., 2002; UEDA et al., 2003; WU et al., 2001), assim como foi encontrado no presente trabalho, onde a maior atividade enzimática foi observada em bactérias do gênero Aeromonas.

Apesar da atividade enzimática apresentada pelas Aeromonas sp. ter sido maior em comparação com as outras bactérias testado nesse trabalho, é importante salientar que nem todas as bactérias desse gênero apresentaram altos valores de produção enzimática, como por exemplo, os isolados $\mathrm{CH}_{\mathrm{T}}, \mathrm{CH}_{104_{\mathrm{B}}}$ e $\mathrm{CHZ208}$ que não mostraram atividade enzimática, apesar de terem formado halos com diâmetros de 4,13, 4,89 e 5,47 mm, respectivamente.

Inúmeros trabalhos têm demonstrado o potencial quitinolítico de bactérias pertencentes ao filo Firmicutes, entre elas as várias espécies de Bacillus e de Paenibacillus, as quais têm sido utilizadas com freqüência como agentes de biocontrole contra fungos (BRATTACHARYA et al., 2007; CODY, 1989; JUAREZ-JIMENEZ et al., 2008; LIU et al., 2002; OUTTRUP e JERGENSEN, 2002). Bactérias quitinolíticas pertencentes ao gênero Stenotrophomonas são capazes de produzir enzimas extracelulares e também têm sido utilizadas no controle de fungos patogênicos (KOBAYASHI et al., 2002; ZHANG et al., 2001). Entretanto, dentre as 29 bactérias quitinolíticas que foram identificadas pelo sequenciamento parcial da região $16 \mathrm{~S}$ rRNA como pertencentes ao filo Firmicutes, apenas uma bactéria (CH267) apresentou atividade enzimática capaz de liberar GlcNAc a partir de quitina coloidal e nenhuma das nove Stenotrophomonas sp. identificadas nesse trabalho apresentaram esse tipo de atividade enzimática.

Os gêneros Vibrio, Micromonospora, Cellulomonas, Pseudomonas, Xanthomonas $e$ Streptomyces que foram isolados de amostras coletadas no Canal de São Sebastião, Ubatuba e Baixada Santista também não apresentaram atividade enzimática capaz de liberar GlcNAc a partir de quitina coloidal, mesmo todas tendo apresentado halo de hidrólise de quitina em meio mínimo contendo quitina coloidal. Apesar disso, muitos trabalhos tem demonstrado a capacidade dessas bactérias de degradar quitina (GOMES et al., 2000; SVITIL et al., 1997; YAMAOKA et al., 1999; WANG et al., 1997).

Bacillus thuringiensis nativos do México mostraram a maior atividade quitinolítica a $57,2{ }^{\circ} \mathrm{C}$ (BARBOSA-CORONA et al., 2003) e em outro trabalho B. thuringiensis HD-1 apresentou atividade quitinolítica ótima a $65^{\circ} \mathrm{C}$ e pH 6.5 (ARORA et al., 2003). Wang et al. (2009) verificaram que a máxima atividade quitinolítica de Bacillus cereus TKU006 foi encontrada a $50{ }^{\circ} \mathrm{C} \mathrm{e} \mathrm{pH} \mathrm{9.0.} \mathrm{Xanthomonas} \mathrm{sp.} \mathrm{apresentou} \mathrm{atividade} \mathrm{quitinolítica} \mathrm{ótima} \mathrm{em} \mathrm{pH}$ 
variando de 4.0 a 6.0 (YAMAOKA et al., 1999). Esses resultados sugerem que outros estudos precisam ser realizados para verificar a temperatura, $\mathrm{pH}$ e tempo ótimo de incubação para que as bactérias quitinolíticas que não apresentaram atividade detectável a $27{ }^{\circ} \mathrm{C}, \mathrm{pH} 7,0$ e 96 horas de incubação possam expressar enzimas quitinolíticas em meio líquido, visto que elas produziram halo de hidrólise de quitina em MMQ1.

Três bactérias identificadas nesse estudo como Serratia sp. apresentaram 0,530 U. $\mathrm{mL}^{-1}$ e $1,88 \mathrm{U} \cdot \mathrm{mL}^{-1}$ e $0,830 \mathrm{U} \cdot \mathrm{mL}^{-1}$ de enzimas necessárias a liberação de GlcNaC, os quais foram superiores aos valores encontrados por Reid e Ogrydziak (1981), onde verificaram que Serratia marcescens produziu 0,283 U. $\mathrm{mL}^{-1}$. Mejía-Saulés et al. (2006) investigou a produção de enzimas produzidas por Serratia marcescens e verificou que de 102 cepas, apenas 57 apresentaram atividade quitinolítica.

A bactéria quitinolítica (CHZ165) identificada como Ralstonia sp. e isolada de amostra de plâncton do Canal de São Sebastião não apresentou atividade enzimática capaz de liberar GlcNAc a partir de quitina coloidal a $27{ }^{\circ} \mathrm{C}, \mathrm{pH}$ 7,0 e 96 horas de incubação. Em contrapartida, Sutrisno et al. (2004) verificaram que Ralstonia sp. A-471, isolada de um sistema de compostagem de resíduos contendo quitina, apresentava $\mathrm{pH}$ e temperatura ótima para expressão de enzimas quitinolíticas a 5.0 e $70^{\circ} \mathrm{C}$, respectivamente.

\subsubsection{Quantificação da enzima $\beta$ - $N$-acetil-glicosaminidase produzida pelas bactérias quitinolíticas}

O uso de p-nitrofenol ligado à GlcNAc ou a oligossacarídeos de quitina foi primeiramente reportado por Roberts e Selitrennikoff (1998) e, a partir dessa data esse substrato tem sido amplamente utilizado para quantificação de enzimas quitinolíticas devido à rapidez e à sensibilidade do método (BASSLER et al., 1991; FRÄNDBERG e SCHNÜRER, 1994a; HOWARD, M. B., 2003; KEYHANI e ROSEMAN, 1999; MATSUO et al., 1999; ORIKOSHI et al., 2005; SUGINTA, 2007; SVITIL et al., 1997;).

As 492 bactérias quitinolíticas foram submetidas à quantificação da enzima $\beta$ - $N$-acetilglicosaminidase utilizando o substrato $\mathrm{p}$-Nitrofenil $\beta$ - $N$-acetil-glicosamine (pNP-GlcNAc). Nesse ensaio, foram observadas valores de produção enzimática variando de 0,00 a 2,968 U de $\beta$ - $N$-acetil-glicosaminidase e novamente a produção enzimática das bactérias quitinolíticas isoladas da Baixada Santista foi maior, em comparação com as bactérias isoladas nos outros dois locais de coleta, confirmando que a atividade enzimática de bactérias presentes em 
estuários é maior do que a de bactérias presentes em água doce e oceanos (CUNHA et al., 2000; JACKSON et al., 1995; JORGENSEN et al., 1999; PATEL et al., 2000). Em comparação com os ensaios discutidos anteriormente, nesse experimento não foram observadas diferenças estatisticamente significantes entre a produção de $\beta$ - $N$-acetilglicosaminidase em relação ao ponto de coleta onde as bactérias foram isoladas. No entanto, a bactéria quitinolítica que apresentou a maior produção de $\beta$-N-acetil-glicosaminidase foi isolada no ponto 3 da Baixada Santista.

Analisando a atividade enzimática das bactérias que foram submetidas ao seqüenciamento da região $16 \mathrm{~S}$ rRNA verificamos que as bactérias que produziram > 1,0 U de $\beta$ - $N$-acetil-glicosaminidase foram identificadas como Aeromonas sp., sendo que o isolado CH125 produziu 2,030 U. ml ${ }^{-1}$. Resultado similar foi observado no trabalho de Huang et al., (1996), onde observaram que uma Aeromonas sp. (1.4 U. $\mathrm{ml}^{-1}$ ) apresentou a maior atividade enzimática entre outras bactérias gram-negativas e gram-positivas isoladas. No presente trabalho, duas bactérias gram-negativas, sendo uma isolada do Canal de São Sebastião e outra da Baixada Santista, apresentaram atividade enzimática maior que o isolado CH125. No entanto, eles não foram identificados através do seqüenciamento da região $16 \mathrm{~S}$ rRNA.

Apesar da maior atividade de $\beta-N$-acetil-glicosaminidase ter sido evidenciada em membros do gênero Aeromonas, foi verificado que algumas bactérias quitinolíticas também identificadas nesse gênero produziram baixa quantidade dessa enzima, sendo que bactérias como a $\mathrm{CH} 228$, CHZ39 e $\mathrm{CHZ42}$ entre outras, não produziram a enzima $\beta$ - $N$-acetilglicosaminidase. No entanto, as bactérias que não produziram essa enzima apresentaram $>99 \%$ de identidade, através da análise do sequenciamento parcial da região $16 \mathrm{~S}$ rRNA, com a bactéria quitinolítica $\mathrm{CH} 07$ que produziu > 1,0 U. ml ${ }^{-1}$ de $\beta$ - $N$-acetil-glicosaminidase. Todavia, o sequenciamento e análises filogenéticas do gene chiA tem mostrado que esse gene está sujeito a transferência lateral de genes entre grupos de bactérias e que outros mecanismos como a duplicação do gene podem também estar ocorrendo (HUNT et al., 2008).

Ao comparar a produção enzimática exibida pelas bactérias pertencentes ao filo Firmicutes no ensaio com p-nitrofenol (item 6.3.4) com os resultados discutidos no item 6.3.3, verificamos que apesar de ter apresentado baixa produção enzimática, $48 \%$ do total de Paenibacillus sp. e Bacillus sp. identificados nesse trabalho produziram a enzima $\beta$-N-acetilglicosaminidase e o mesmo aconteceu com as bactérias quitinolíticas identificadas como Stenotrophomonas sp. e Ralstonia sp. Diante disso, pode se concluir que os ensaios utilizando p-nitrofenol são mais sensíveis para detecção de atividade quitinolítica, especialmente quando 
são utilizados microrganismos que expressam baixa quantidade de enzimas quitinolíticas em meio líquido.

Entretanto, de forma geral todos os isolados gram-positivos (bacilos e cocos) e grampositivos filamentosos apresentaram valores muito baixos de produção $\beta$ - $N$-acetilglicosaminidase, em comparação com os isolados gram-negativos. No trabalho de Frändberg e Schnürer, 1994b, Bacillus pabuli K1 não apresentou atividade de $\beta$ - $N$-acetilglicosaminidase. Por outro lado, Gomes et al., 2000 verificaram que dois Streptomyces sp. isolados do cerrado do Brasil, produziram 1,88 e 1,99 $\mathrm{U}$. $\mathrm{mL}^{-1}$ de $\beta$ - $N$-acetil-glicosaminidase. Entretanto, no presente trabalho, dentre as bactérias quitinolíticas gram-positivas filamentosas, duas bactérias identificadas como Streptomyces sp. $\left(0,101\right.$ U. $\left.\mathrm{mL}^{-1}\right)$ e Micromonospora sp. (0,287 U. $\left.\mathrm{mL}^{-1}\right)$ apresentaram a maior produção de $\beta$ - $N$-acetilglicosaminidase.

\subsubsection{Quantificação das enzimas quitobiosidase e endoquitinase produzidas pelas bactérias quitinolíticas}

Analisando a produção enzimática das 29 bactérias quitinolíticas selecionadas que foram submetidas à quantificação das enzimas quitobiosidase e endoquitinase, verificamos um bom potencial de produção dessas enzimas, visto que 62\% e $79 \%$ dos isolados apresentaram valores de produção de quitobiosidase e endoquitinase, respectivamente, mais elevados do que o controle positivo utilizado nesse trabalho.

Frändberg e Schnürer (1994a) estudaram dez bactérias em relação à atividade quitinolítica e verificaram que a produção de enzimas necessárias para liberar GlcNAc e produção de halo de hidrólise de quitina estava altamente correlacionada. Porém, esse tipo de correlação foi encontrada em apenas uma das bactérias. Em contrapartida, no presente estudo, analisando apenas as 18 bactérias quitinolíticas isoladas da Baixada Santista e que foram submetidas aos ensaios enzimáticos, foi verificada uma correlação negativa entre diâmetro do halo de hidrólise de quitina e produção $\beta$ - $N$-acetil-glicosaminidase $(\mathrm{p}=0,002$ e $\mathrm{r}=-0,668)$. Também foi encontrada correlação, porém positiva entre $\beta$-N-acetil-glicosaminidase $(\mathrm{p}=$ $0,007$ e $r=0,610)$, quitobiosidase $(p=0,001$ e $r=0,705)$ e endoquitinase $(p=0,002$ e $r=$ 0,672) com produção de enzimas necessárias para formar GlcNAc. As bactérias quitinolíticas isoladas de amostras de plâncton apresentaram uma forte correlação entre produção de endoquitinase e enzimas necessárias para formar GlcNAc $(p=0,003$ e $r=0,929)$. E todas as 
bactérias quitinolíticas isoladas da Baixada Santista apresentaram correlação entre produção de quitobiosidase e endoquitinase.

A única bactéria gram-positiva (CH267), dentre as 29 bactérias utilizadas para verificar a produção das enzimas quitobiosidase e endoquitinase e que foi identificada como Paenibacillus sp., produziu uma quantidade muito baixa das duas enzimas, em comparação com as bactérias gram-negativas testadas. Por outro lado, dentre os gram-positivos obtidos nesse estudo, a bactéria quitinolítica $\mathrm{CH} 267$ foi a que apresentou o maior halo de hidrólise de quitina $(6,72 \mathrm{~mm})$. Resultado semelhante foi produzido por duas bactérias (CH133 e CHZ240) identificadas como Aeromonas sp., as quais não produziram quitobiosidase e endoquitinase, apesar de terem produzido halo de hidrólise de quitina com mais de 4,0 mm diâmetro.

Nesse experimento, foi observada uma diferença marcante entre a atividade enzimática apresentada pelas bactérias quitinolíticas isoladas de amostras de água do mar e de amostras de plâncton. Essa diferença já havia sido evidenciada nos experimentos anteriores, sendo necessário estabelecer dois critérios para selecionar as bactérias quitinolíticas que seriam submetidas à quantificação das enzimas quitobiosidase e endoquitinase. Entretanto, era esperado que as bactérias isoladas de amostras de plâncton apresentassem uma maior produção de enzimas quitinolíticas em comparação com as bactérias isoladas de amostras de água, pois normalmente as bactérias associadas a partículas ou a organismos vivos apresentam uma maior atividade enzimática (DeLong et al., 1993). Em contrapartida, na Baixada Santista, ambiente com maior presença de partículas em suspensão na coluna d'água, provenientes de atividades antropogênicas, foram encontradas as bactérias quitinolíticas com maior potencial enzimático.

Apesar de termos observado correlação entre $\beta$ - $N$-acetil-glicosaminidase, quitobiosidase, endoquitinase e a produção de enzimas necessárias para formar GlcNAc, era esperado encontrar uma correlação maior entre esses três ensaios, visto que no experimento de produção de enzimas necessárias para a liberação de GlcNAc são detectadas todas as enzimas quitinolíticas. No entanto, diferentes enzimas quitinolíticas podem não ter sido detectadas nos ensaios utilizando p-nitrofenol, visto que algumas espécies bacterianas podem expressar várias quitinases. B. circulans WL-12, por exemplo, expressa seis diferentes quitinases e $B$. licheniformis $\mathrm{X}-7 \mathrm{u}$ expressa quatro tipos de quitinases termoestáveis (TAKAYANAGI et al., 1991; WATANABE et al., 1990a). 
Além disso, novas quitinases bacterianas têm sido identificadas frequentemente a cada ano. Itoi et al. (2007) identificaram uma nova endoquitinase de $110 \mathrm{kD}$ produzida por Vibrio proteolyticus. Jang et al. (2005) isolaram uma bactéria do gênero Pseudomonas em amostras de alga marinha (Porphyra dentata) e encontraram um novo gene que codifica para a quitinase A dessa bactéria. Esse gene possui 1602 pb e codifica para uma proteína de 534 aminoácidos e peso molecular de $55 \mathrm{kD}$ a qual possui o domínio estrutural diferente das demais quitinases da família 18. Alteromonas sp. secreta quatro diferentes quitinases na presença de quitina (ChiA, ChiB, ChiC e ChiD) (ORIKOSHI et al., 2005) e foi verificado que Streptomyces coelicolor possui 13 genes que codificam para a produção de quitinases (KAWASE et al., 2006).

Todas essas diferenças encontradas, no presente trabalho, em relação à atividade quitinolítica bacteriana apresentada por bactérias isoladas de diferentes locais e tipos de amostras confirmam os resultados obtidos em trabalhos anteriores, os quais afirmam que a degradação de quitina é realizada por um caminho complexo que incluem múltiplas enzimas e vários domínios funcionais de ligação à quitina (HUNT et al., 2008; SVITIL et al., 1997; WANG et al., 1997). Li e Roseman (2004) sugerem que o processo de degradação total de quitina é realizado por dezenas de enzimas e proteínas estruturais, que incluem provavelmente várias quitinases extracelulares, sistemas específicos de quimiotaxia para encontrar os oligossacarídeos de quitina, quitoporinas específicas na membrana externa, pelo menos duas hidrolases específicas para oligossacarídeos de quitina presentes no espaço periplasmático, três sistemas de transporte presentes na membrana interna e no mínimo seis enzimas citoplasmáticas que convertem os oligossacarídeos de quitina a frutose-6- $\mathrm{P}, \mathrm{NH}_{3}$ e acetato. Os autores ainda afirmam que todos os genes envolvidos nessa cascata metabólica são rigorosamente regulados for fatores químicos e ambientais.

É interessante ressaltar ainda, que essa diversidade de genes que codificam para a produção de enzimas quitinolíticas observada em inúmeros trabalhos desenvolvidos no decorrer dos anos e a diferença de expressão dessas enzimas por bactérias pertencentes ao mesmo gênero encontradas no atual trabalho, pode ser resultado da transferência horizontal de genes, como foi proposto por vários pesquisadores (HUNT et al., 2008; MEIBOM et al. 2005, ZO et al. 2002; XIAO et al., 2005). 


\subsection{CARACTERIZAÇÃO MOLECULAR DAS BACTÉRIAS QUITINOLÍTICAS}

\subsubsection{Caracterização molecular pelas técnicas de ERIC-PCR e BOX-PCR}

As técnicas de rep-PCR (BOX-PCR, ERIC-PCR e REP-PCR) são consideradas importantes ferramentas para estabelecer a relação genética entre microrganismos, avaliar a distribuição e a evolução de cepas epidêmicas e realizar a tipagem de uma ampla variedade de bactérias gram-negativas e vários gêneros de bactérias gram-positivas, além de apresentarem alto poder discriminatório e baixo custo (LOUWS et al., 1996; RADEMAKER e de BRUIJN, 1997; VERSALOVIC et al., 1998; OLIVE e BEAN, 1999).

Apesar das técnicas de tipagem molecular terem sido aplicadas com maior frequência para propósitos epidemiológicos, alguns trabalhos já demonstram a utilização dessas técnicas em estudos de diversidade microbiana em amostras ambientais. Entretanto, a maioria desses trabalhos enfoca um gênero ou grupo específico de bactérias (CHIMETTO et al., 2009; McLELLAN, 2004; MASCO et al., 2003; PELLIZARI et al., 1996; RIVERA et al., 1995; ZLATKIN et al., 1996).

Diante disso, as técnicas de ERIC-PCR e BOX-PCR foram empregadas nesse trabalho por dois motivos: (1) conhecer a diversidade genética entre os isolados quitinolíticos obtidos de amostras de água do mar e plâncton coletadas no litoral do estado de São Paulo e, (2) selecionar isolados representativos de cada agrupamento para serem submetidos à identificação através do seqüenciamento da região $16 \mathrm{~S}$ rRNA. No entanto, devido ao número reduzido de bactérias presentes em cada agrupamento que apresentaram $\geq 70 \%$ de similaridade entre os seus membros, não foi possível utilizar os resultados obtidos pelas duas técnicas como critério de seleção das bactérias a serem identificadas, sendo necessário estabelecer outra forma de selecionar as bactérias que seriam submetidas ao seqüenciamento do gene $16 \mathrm{~S}$ rDNA.

Analisando primeiramente a sensibilidade dos dois métodos de tipagem molecular, foi verificado que o BOX-PCR apresentou um melhor desempenho, visto que de um total de 399 bactérias quitinolíticas, apenas $30(7,5 \%)$ apresentaram $\leq 2$ produtos de amplificação pela técnica de BOX-PCR, enquanto que pelo ERIC-PCR o número foi de 114 (29\%) isolados que apresentaram $\leq 2$ produtos de amplificação. Resultados similares foram encontrados no trabalho de Rodrigues, 2002 onde 30 dos 61 isolados degradadores de xenobióticos que foram analisados não apresentaram produtos de amplificação pela técnica de BOX-PCR. 
Utilizando as duas técnicas para avaliar a diversidade genética, verificou-se que nos três ambientes estudados e nos dois tipos de amostras foi encontrada uma alta diversidade genética entre esses isolados tanto pela técnica de ERIC como de BOX-PCR. Essa alta diversidade pôde ser comprovada pela baixa similaridade inicial observada em todos os dendrogramas apresentados nesse trabalho, onde nenhuma técnica apresentou mais de $15 \%$ de similaridade inicial entre os seus isolados.

Inúmeros trabalhos têm demonstrado que a sequência BOX-A1 é bastante conservada e está dispersa em diversos genomas bacterianos (LOUWS, 1996; RADEMAKER e de BRUIJN, 1997; VERSALOVIC et al., 1991). Ciapina (1997), inclusive utilizou as técnicas de rep-PCR para diferenciação genômica de bactérias gram-negativas e gram-positivas e verificou que a técnica de BOX-PCR individualmente foi totalmente eficiente para discriminar o grupo de bactérias gram-negativas do grupo das gram-positivas. No entanto, os resultados apresentados no presente trabalho, demonstraram que a sequência BOX-A1 está presente tanto no genoma de bactérias gram-negativas como no de gram-positivas. Contudo, não foi eficiente para diferenciar as bactérias quitinolíticas gram-positivas das bactérias quitinolíticas gram-negativas.

Resultados semelhantes aos obtidos nesse trabalho foram encontrados por BINDE et al. (2009) onde 54 bactérias fixadoras de nitrogênio foram submetidas à técnica de BOX-PCR e observou-se uma alta diversidade genética entre os isolados. Foi verificada uma similaridade inicial de $20 \%$ entre todos os isolados e apenas dois agrupamentos compostos por dois isolados cada um, os quais apresentaram 100\% de similaridade entre si. Além disso, o BOXA1 foi inadequado para agrupar os membros de uma mesma espécie ou gênero.

As sequências intergênicas repetitivas unânimes em enterobactérias (ERIC) já foram identificadas em Escherichia coli, Salmonella enterica, Yersinia enterocolítica, Klebsiella pneumoniae e várias espécies de vibrios, entre eles Vibrio cholerae (SOUZA, 2007; RIVERA et al., 1995; WILSON e SHARP, 2006). No entanto, essas sequências estão presentes em outros microrganismos, como pôde ser observado no presente trabalho, onde foram encontradas em Paenibacillus sp, Aeromonas sp. e até em bactérias gram-positivas filamentosas como Streptomyces $\mathrm{sp}$.

Szczuka e Kaznowaki (2004) utilizaram a sequência ERIC para verificar a clonalidade entre 120 cepas de Aeromonas sp. isoladas de amostras clínicas e ambientais e verificou que não existia similaridade genética entre os isolados e ainda não apresentaram nenhuma relação com a área geográfica em que foram isolados. O mesmo pode ser observado nesse trabalho, 
onde as Aeromonas sp. não mostraram similaridade entre si, em relação ao local de isolamento ou potencial de degradação de quitina.

Segundo alguns autores, as técnicas de rep-PCR permitem a diferenciação de bactérias em nível de espécie e sub-espécie e podem representar o método mais discriminatório e reprodutível de análise de perfil genômico bacteriano (LOUWS et al., 1996; RADEMAKER e de BRUIJN, 1997; VERSALOVIC et al., 1998). Porém, os resultados apresentados no decorrer desse trabalho contradizem o que foi proposto pelos autores acima. Assim, também em outros trabalhos foi verificado que as técnicas de rep-PCR são poderosas ferramentas para detectar a diversidade genética dentro um gênero específico de bactérias, mas é totalmente inadequada para definir espécies ou gêneros (LANGUERRE et al., 1997; MENNA et al., 2009).

É importante ressaltar que a maioria dos trabalhos que utilizaram com sucesso as técnicas de rep-PCR para estudos de diversidade entre diferentes linhagens utilizaram, na maioria das vezes, somente 2 espécies de bactérias, o que poderia justificar a eficiência desses métodos para a caracterização de linhagens dentro de uma mesma espécie, mas não para a identificação e caracterização de diferentes espécies ambientais desconhecidas.

A alta diversidade genética encontrada nesse trabalho pode ser resultado das interações genéticas, como transferência horizontal de genes, transdução e conjugação, visto que o ambiente aquático é um potencial reservatório de genes ( $\mathrm{ZO}$ et al., 2002). Além do mais, assim como Meibom et al. (2005) demonstraram que $V$. cholerae pode adquirir novos genes por transferência horizontal de genes durante o crescimento sobre quitina, outras espécies bacterianas poderiam também estar passando por processos semelhantes.

\subsubsection{Seqüenciamento parcial da região 16S rRNA das bactérias quitinolíticas}

Os ecossistemas aquáticos possuem em sua composição microrganismos autóctones que exercem uma função específica e microrganismos alóctones (não indígenas) que, freqüentemente provêm de atividades antropogênicas. Essas atividades, direta ou indiretamente, têm provocado mudanças irreversíveis na biodiversidade microbiana dos ecossistemas aquáticos (COLWELL, 1996; COLWELL, 1997).

A diminuição da diversidade bacteriana como conseqüência das atividades antropogênicas pode ser claramente observada nesse trabalho, onde a maior diversidade de gêneros de bactérias quitinolíticas foi encontrada em amostras de água do mar coletadas no 
Canal de São Sebastião e em amostras de plâncton coletadas em Ubatuba, ambientes com média e baixa presença de atividade antropogênica, respectivamente. Por outro lado, nas amostras de água do mar coletadas na Baixada Santista, ambiente com alto índice de impacto antropogênico, foi verificada a menor diversidade de gêneros bacterianos, principalmente em amostras de plâncton. Contudo, em ambiente com alta atividade antropogênica foram obtidos os isolados com maior potencial de degradação de quitina.

A maior porcentagem de bactérias quitinolíticas foi identificada como Aeromonas sp, sendo que a maior freqüência foi encontrada em amostras de plâncton coletadas na Baixada Santista. Todavia, é importante salientar que o gênero Aeromonas é autóctone em ecossistemas aquáticos de água doce, em estuários e regiões costeiras, e ainda é encontrado em amostras de esgoto (KROVACEK et al., 1994; MONFORT e BALEUX, 1990). No entanto, existem poucos relatos de membros do gênero Aeromonas associados à zooplâncton marinho (DUMONTET et al., 2000). A capacidade de degradar quitina já foi verificada em Aeromonas sp. (UEDA et al., 1998), Aeromonas hydrophila (WU et al., 2001) e Aeromonas caviae (LI et al., 2005). Hiraga et al. (1997) isolou A. hydrophila do ambiente marinho e verificou que essa bactéria secretou cinco quitinases e uma $\beta$ - $N$-acetil-glicosaminidase quando quitina foi utilizada como única fonte de carbono.

Dentre as 83 Aeromonas sp. isoladas de amostras de água do mar e plâncton dos três locais de coleta, apenas cinco bactérias (CHZ308, CHZ223, CHZ319, CHZ223 e CHZ202) apresentaram < 99\% de identidade com a bactéria CH07 que foi selecionada como isolado representativo do gênero Aeromonas (Figura 43). Todavia, nenhuma dessas bactérias apresentou características enzimáticas que as diferenciassem das demais Aeromonas sp. isoladas nesse trabalho. Em contrapartida, bactérias quitinolíticas que apresentaram $<99 \%$ de identidade com a bactéria $\mathrm{CH} 07$, apresentaram > 70\% de similaridade com as bactérias CHZ308, CHZ223 e CHZ319 pela técnica de rep-PCR.

O gênero Stenotrophomonas compreende pelo menos oito espécies e embora esteja amplamente distribuído no ambiente, o seu principal reservatório é o solo e as plantas. Membros desse gênero desempenham um importante papel ecológico nos ciclos do nitrogênio e enxofre e ainda podem realizar interações benéficas com várias espécies de plantas. Além disso, a maioria das bactérias pertencentes ao gênero Stenotrophomonas podem produzir enzimas extracelulares, entre elas quitinases, proteases, lipases, nucleases e elastases, as quais têm se mostrado importantes no processo de colonização das plantas por outros microrganismos da rizosfera. A maioria das Stenotrophomonas sp. são altamente adaptadas a 
ecossistemas que apresentam limitação de nutrientes, como é caso de ambientes marinhos oligotróficos (RYAN et al., 2009). Essa adaptação das bactérias do gênero Stenotrophomonas foi observada no presente trabalho, onde a maior frequência de bactérias quitinolíticas foi obtida em amostras coletadas em Ubatuba (33\%).

As bactérias pertencentes ao gênero Pseudomonas são abundantes em vários ambientes, tais como água e solo e elas estão relacionadas à decomposição de matéria orgânica e promovem o crescimento de plantas (HOLLOWAY, 1992). Três bactérias quitinolíticas identificadas como Pseudomonas sp. pelo sequenciamento parcial da região $16 \mathrm{~S}$ rRNA e isoladas de amostras de água plâncton coletadas no Canal de São Sebastião e Ubatuba apresentaram > 99\% de identidade entre si. Entretanto, a única Pseudomonas sp. (CH324), isolada de amostra de água do mar coletada na Baixada Santista, apresentou < $99 \%$ de identidade com as outras Pseudomonas sp. obtidas nesse trabalho. Em contrapartida, a bactéria $\mathrm{CH} 324$ apresentou $75 \%$ de similaridade com a bactéria CHZ165 pelo BOX-PCR, a qual foi identificada como Ralstonia sp. pelo sequenciamento parcial da região $16 \mathrm{~S}$ rRNA.

Bactérias pertencentes à família Vibrionaceae tem sido extensivamente estudadas em relação ao seu potencial de degradação de quitina (AMAKO et al., 1987; BASSLER et al., 1991; BHOWMICK et al., 2007; FUKASAWA et al., 1992; ITOI et al., 2007; KEYHANI e ROSEMAN, 1999; MEIBOM et al., 2004). Vibrios são autóctones do ambiente marinho e como são heterotróficos obrigatórios eles utilizam uma ampla variedade de fontes de carbono para obter energia (THOMPSON e POLZ, 2006). Apesar dos membros da família Vibrionaceae serem isolados com facilidade em meios de cultura, nesse trabalho, somente foram obtidos duas bactérias, ambas isoladas de amostras de água do mar da Baixada Santista, as quais foram identificadas como Vibrio sp. Porém, outras bactérias pertencentes a essa família podem ter sido isoladas, mas não foram submetidas ao sequenciamento da região $16 \mathrm{~S}$ rRNA.

O gênero Shewanella foi descrito pela primeira vez por MacDonell e Colwell (1985) e as bactérias pertencentes a esse gênero são amplamente distribuídas em ambientes marinhos e de água doce (BOZAL et al., 2002; YANG et al., 2006), em estuários (SKERRATT et al., 2002). No presente trabalho, uma bactéria quitinolítica (CHZ45) isolada de amostra de plâncton coletada no Canal de São Sebastião apresentou 99\% de similaridade com uma Shewanella putrefaciens (T) ATTCC 8071.

Foram obtidas, nesse trabalho, duas bactérias quitinolíticas (CHZ75 1 e CHZ44), ambas isoladas de amostras de plâncton, que apresentaram > 97\% de similaridade com o gênero 
Rheinheimera. Esse gênero é formado por três espécies: Rheinheimera baltica (BRETTAR et al., 2002), Rheinheimera pacifica (ROMANENKO et al., 2003) e Rheinheimera perlucida (BRETTAR et al., 2006) e uma nova espécie, Rheinheimera aquimaris isoladas de amostras de água do mar da Coréia foi descrita por YOON et al. (2007). Apesar da baixa atividade quitinolítica apresentada pelas bactérias $\mathrm{CHZ44}$ e $\mathrm{CHZ75}$, não foram encontrados outros trabalhos descrevendo a capacidade de degradar quitina desse gênero bacteriano.

Bactérias pertencentes ao gênero Serratia são amplamente distribuídas na natureza, sendo que várias espécies já foram isoladas de amostras de água, solo, animais (incluindo o homem) e de superfície de plantas (GRIMONT, F. e GRIMONT, P.A.D, 1992). Na presente pesquisa, o maior número de Serratia sp. foi obtida em amostras de plâncton coletadas na Canal de São Sebastião e apenas uma bactéria foi isolada de amostra de água do mar coletada na Baixada Santista. Entretanto, todas as nove bactérias identificadas como Serratia sp. apresentaram > 99\% de identidade entre si, através da análise do sequenciamento parcial da região 16S rRNA.

Os outros gêneros bacterianos pertencentes ao filo Proteobacteria e encontrados nesse trabalho, mas em baixa freqüência, foram: Dyella, Xanthomonas, Pseudoxanthomonas, Ralstonia e Pelomonas. Entretanto, dentre essas bactérias, não foram encontrados trabalhos descrevendo a capacidade de degradar quitina e presença em amostras de água do mar apenas do gênero Dyella (FERA et al., 2007; RYAN et al., 2009; SUTRISNO et al., 2004; YAMAOKA et al., 1999).

Somente dois gêneros bacterianos pertencentes ao filo Firmicutes foram isolados nesse trabalho (Bacillus sp. e Paenibacillus sp.), sendo que a maior frequência foi de bactérias quitinolíticas pertencentes ao gênero Paenibacillus. Todavia, esses dois gêneros bacterianos têm sido isolados com frequência de amostras do ecossistema marinho (CHOI et al., 2008; ROMANENKO et al., 2008; SIEFERT et al., 2000). Dentre as bactérias desse filo, a maior diversidade foi de membros do gênero Paenibacillus, sendo que de um total de 18 Paenibacillus sp. isolados nos três locais de coleta, sete apresentaram < 99\% de identidade com outros Paenibacillus sp. obtidos.

Até pouco tempo, acreditava-se que os actinomicetos não eram comuns no ecossistema marinho mas, na última década as informações sobre diversidade de actinobactérias marinhas cresceram consideravelmente devido ao interesse pela descoberta de novos produtos bioativos, como por exemplo, antibióticos e enzimas (BULL et al., 2005; WARD e BORA, 2006). Com isso, surgiu também o interesse pelo conhecimento da 
diversidade de actinobactérias quitinolíticas, sendo que atualmente, sabe-se que inúmeras bactérias pertencentes à classe Actinobacteria são capazes de hidrolisar quitina, dentre as quais podemos citar: Curtobacterium sp. Promicromonospora sp., Actinoplanes brasiliensis, Micromonospora sp., Nocardiopsis sp. e Streptomyces sp., Cellulomonas sp. (KAWASE et al., 2004).

A diversidade de actinomicetos quitinolíticos também pôde ser evidenciada no presente trabalho, onde sete gêneros diferentes de actinobactéria foram encontrados, com prevalência dos gêneros Micromonospora sp. e Streptomyces sp. Bredholdt et al. (2007) descreveram pela primeira vez a presença do gênero Glycomyces em amostras de sedimento úmido do ambiente marinho e até o ano de 2008 o gênero Glycomyces era composto por sete espécies, sendo que todos são de origem terrestre (QIN et al., 2008). Entretanto, não foram encontrados trabalhos descrevendo a presença do gênero Glycomyces em amostras de água do mar, assim como foi observado nesse trabalho.

O gênero Sanguibacter foi inicialmente isolado de amostras de sangue de vacas saudáveis (FERNÁNDEZ-GARAYZÁBAL et al., 1995). Porém, posteriormente foi evidenciada a presença desse gênero em amostras de sedimento marinho e em reservatórios de óleo (HUANG et al., 2005). No presente trabalho, a bactéria quitinolítica CH322 isolada de amostra de água do Canal de São Sebastião apresentou 97,8\% de similaridade com o gênero Sanguibacter descrito por FERNÁNDEZ-GARAYZÁBAL et al. (1995).

A bactéria quitinolítica $\mathrm{CH} 275$ isolada de amostras de água do mar da Baixada Santista apresentou $99,7 \%$ de similaridade com uma bactéria pertencente ao gênero Isoptericola sp., a qual foi isolada de túmulos de "Etrusca Mercareccia" na Itália (SPROCATI et al., 2007 - trabalho não publicado - GenBank EU249554). No entanto, Isoptericola sp. tem sido isolada com maior freqüência em amostras de solo (YOON et al., 2006; ZHANG et al., 2005), mas também já foi isolado de amostras do Golfo Pérsico e a sua capacidade de hidrolisar hidrocarbonetos foi verificada (AL-AWADHI et al., 2007). 


\section{CONCLUSÕES}

1. A metodologia de preparação de quitina coloidal e o meio de cultura selecionados possibilitaram isolar grande número de bactérias quitinolíticas.

2. As maiores contagens de bactérias quitinolíticas foram encontradas em amostras de água e plâncton da Baixada Santista, ambiente com alta atividade antropogênica.

3. As bactérias quitinolíticas isoladas da Baixada Santista apresentaram os maiores halos de hidrólise de quitina em ágar mineral contendo quitina coloidal e a maior atividade enzimática em meio de cultura líquido.

4. A técnica de BOX-PCR foi mais sensível para diferenciar as bactérias quitinolíticas dentro de um mesmo gênero. Porém, nenhuma das duas técnica de rep-PCR puderam diferenciar as bactérias quitinolíticas em nível de gênero ou espécie.

5. A maior diversidade de gêneros de bactérias quitinolíticas foi encontrada em amostras do Canal de São Sebastião e Ubatuba, ambientes com médio e baixo nível de impacto antropogênico, respectivamente.

6. A diversidade de bactérias quitinolíticas foi baixa nas amostras de água do mar e plâncton coletadas na Baixada Santista com predominância do gênero Aeromonas.

7. O nível de contaminação fecal presente em cada ambiente estudado influenciou significativamente na diversidade e no potencial enzimático das bactérias quitinolíticas. 


\section{REFERÊNCIAS BIBLIOGRÁFICAS*}

ABESSA, D.M.S.; CARR, R.S.; BAUER, R.F. R; SOUSA, E.C.P.M.; HORTELANI, M.A.; SARKIS, J.E. Influence of a Brazilian sewage outfall on the toxicity and contamination of adjacent sediments. Marine Pollution Bulletin, v. 50, p. 875-885, 2005.

ABREU, P.C.; BIDDANDA, B.B.; ODEBRECHT, C. Bacterial dynamics of the Patos Lagoon estuary, Southern Brazil $\left(32^{\circ} \mathrm{S} ; 52^{\circ} \mathrm{W}\right)$ : relationship with phytoplankton production and suspended material. Estuarine Coastal and Shelf Science, v. 35, p. 621-635, 1992.

ADAMS, D.J. Fungal cell wall chitinases and glucanases. Microbiology, v. 150, p. 20292035, 2004.

AJIT, N. S.; VERMA, R.; SHANMUGAM, V. Extracellular chitinases of fluorescent pseudomonads antifungal to Fusarium oxysporum f. sp. dianthi causing carnation wilt. Current Microbiology, v. 52, n. 4, 310-316, 2006.

AKUTSU, K.; HIRATA, A.; YAMAMOTO, M.; HIRAYAE, K.; OKUYAMA, S.; HIBI, T. Growth Inhibition of Botrytis spp. by Serratia marcescens B2 isolated from Tomato Phylloplane. Annals of Phytopathological Society of Japan, v. 59, p. 18-25, 1993.

AL-AWADHI, H.; SULAIMAN, R.H.; MAHMOUD, H.M.; RADWAN, S.S. Alkaliphilic and halophilic hydrocarbon-utilizing bacteria from Kuwaiti coasts of the Arabian Gulf. Applied Microbiology and Biotechnology, v. 77, p. 183-186, 2007.

ALLDREDGE, A.L.; GOTSCHALK, C.C. The relative contribution of marine snow of different origins to biological processes in coastal waters. Continental Shelf Research, v. 10, p. 41-58, 1990.

ALOISE, P.A.; LUMME, M., HAYNES, C.A. N-acetyl D-glucosamine production from chitin waste using chitinase from Serratia marcescens. In: MUZZARELLI, R.A.A. (Ed.). Chitin Enzymology, Italy: European Chitin Society, 1996. p. 581-594.

ALTSCHUL, S.F.; GISH, W.; MILLER, W.; MYERS, E.W.; LIPMAN, D.J. Basic local alignment search tool. Journal of Molecular Biology, v. 215, p. 403-410, 1990.

AMAKO, K.; SHIMODORI, S.; IMOTO, T.; MIAKE, S.; UMEDA, A. Effects of chitin and its soluble derivatives on survival of Vibrio cholerae O1 at low temperature. Applied and Environmental Microbiology, v. 53, n. 3, p. 603-605, 1987.

AMANN, R.; LUDWIG, W. Ribosomal RNA-targeted nucleic acid probes for studies in microbial ecology. FEMS Microbiology Reviews, v. 24, n. 5, p. 555-565, 2000.

\footnotetext{
* De acordo com: ASSOCIAÇÃO BRASILEIRA DE NORMAS TÉCNICAS. NBR 6023: Informação e documentação: referências: elaboração. Rio de Janeiro, 2002
} 
AMANN, R.I.; LUDWIG, W.; SCHLEIFER, K.H. Phylogenetic identification and in situ detection of individual microbial cells without cultivation. Microbiological Reviews, v. 59, p. 143-169, 1995.

AMERICAN PUBLIC HEALTH ORGANIZATION. Microbiological examination. In: Microbiological Examination of Water and Wastewater. 20th ed. Washington, D.C. APHA, AWWA, WEF, 1998.

ANCONA, C.M. Aspectos da variação espacial e temporal da biomassa e produção fitoplânctônica e parâmetros correlatos no estuário e baía de Santos. $229 \mathrm{f}$. Dissertação (Mestrado em Oceanografia) - Instituto Oceanográfico, Universidade de São Paulo, São Paulo, 2007.

ANGEL, M.V. Biodiversity of the Pelagic Ocean. Conservation Biology, v. 7, n. 4, p. 760$772,1993$.

ANIL, K.; SESHAGIRIRAO, K.; PODILE, A. R. A simple, rapid and yet less expensive method to detect chitinase in agarose plates. Journal of Biochemical and Biophysical Methods, v. 70, p. 683-684, 2007.

ARGENTINO-SANTOS, R.C. Avaliação ecotoxicológica do sedimento do local de disposição do material dragado do Porto de Santos e da área de influência direta. $124 \mathrm{f}$. Dissertação (Mestrado em Oceanografia) - Instituto Oceanográfico, Universidade de São Paulo, São Paulo, 2006.

ARORA, N.; AHMAD, T.; RAJAGOPAL, R.; BHATNAGAR, R. K. A constitutively expressed $36 \mathrm{kDa}$ exochitinase from Bacillus thuringiensis HD-1. Biochemical and Biophysical Research Communications, v. 307, p. 620-625, 2003.

AUMEN, N.G. Microbial succession on a chitinous substrate in a woodland stream. Microbial Ecology, v. 6, n. 4, p. 317-328, 1981.

AUNPAD, R.; PANBANGRED, W. Cloning and characterization of the constitutively expressed chitinase C gene from a marine bacterium, Salinivibrio costicola strain 5SM-1. Journal of Bioscience and Bioengineering, v. 96, n. 6, p. 529-536, 2003.

AVELIZAPA, L.I.R.; CAMARILLO, R. C.; GUERRERO, M.I.; VAZQUEZ, R.R.; IBARRA, J.E. Selection and characterization of a proteo-chitinolytic strain of Bacillus thuringiensis, able to grow in shrimp waste media. World Journal of Microbiology \& Biotechnology, v. 15, n. 2, p. 299-308, 1999.

BARBOZA-CORONA, J. E.; NIETO-MAZZOCCO, E.; VELAZQUEZ-ROBLEDO, R.; SALCEDO-HERNANDEZ, R.; BAUTISTA, M.; JIMENEZ, B.; IBARRA, J. E. Cloning, sequencing, and expression of the chitinases gene chiA74 from Bacillus thuringiensis. Applied and Environmental Microbiology, v. 69, p. 1023-1029, 2003.

BARRETO, C.C. Quitinases do Fungo Entomopatogênico Metarhizium anisopliae. 87 f. Dissertação (Mestrado em Genética e Biologia Molecular) - Universidade Federal do Rio Grande do Sul, 1995. 
BASSLER, B.L.; YU, C.; LEE, C.Y.C.; ROSEMAN, S. Chitin utilization by marine bacteria. Degradation and catabolism of chitin oligosaccharides by Vibrio furnissii. Journal of Biological Chemistry, v. 266, p. 24276-24286, 1991.

BENSON, D. A.; KARSCH-MIZRACHI, I.; LIPMAN, D.J.; OSTELL, J.; WHEELER, D.L. GenBank: update. Nucleic Acids Research, v. 32, p. D23-D26, 2004.

BENTON, A.G. Chitinovorous Bacteria: A Preliminary Survey. Journal of Bacteriology, v. 29 , n. 5 , p. 449-465, 1935.

BERNARD, N. Sur la fonction fungicide des bulbes d' Ophrydeae. Annales des Sciences Naturales. Botanique et Biologie Vegetale, v. 14, p. 221-234, 1911.

BHATTACHARYA, D., NAGPURE, A., GUPTA, R. K. Bacterial chitinases: Properties and potential. Critical Reviews in Biotechnology, v.27, n. 1, p. 21-28, 2007.

BHOWMICK, R.; GHOSAL, A.; CHATTERJEE, N.S. Effect of environmental factors on expression and activity of chitinase genes of vibrios with special reference to Vibrio cholera. Journal of Applied Microbiology, v. 103, p. 97- 108, 2007.

BIDLE, K. D.; FLECHER, M. Comparison of free-living and particle associated bacterial communities in the Chesapeake Bay by stable low molecular-weight RNA analysis. Applied and Environmental Microbiology, v. 61, n. 3, p. 944-952, 1995.

BINDE, D.R.; MENNA, P.; BANGEL, E.V.; BARCELLOS, F.G.; HUNGRIA, M. rep-PCR fingerprinting and taxonomy based on the sequencing of the 16S rRNA gene of 54 elite commercial rhizobial strains. Applied Microbiology and Biotechnology, mar., 2009. Epub ahead of print.

BLACKWELL, J.; PARKER, K.D.; RUDALL, K.M. Chitin fibers of the diatoms Thalassiosira fluviatilis and Cyclotella cryptica. Journal of Molecular Biology, v. 28, 383385, 1967.

BLACKWELL, J.; WEIH, M.A. The structure of chitin-protein complexes. In: ZIKAKIS, J.P. (Ed.). Chitin, chitosan and related enzymes. Orlando: Academic Press, 1984. p. 257-272.

BOOT, R.G.; BLOMMAART, E.F.C.; SWART, E.; VAN DER VLUGT; K.G., BIJL; N., MOE, C.; PLACE, A.; AERTS, J.M.F.G. Identification of a novel acidic mammalian chitinase distinct from chitotriosidase. The Journal of Biological Chemistry, v. 276, n. 9, p. 6770-6778, 2001.

BOUMA, C. L.; ROSEMAN, S. Sugar transport by the marine chitinolytic Bacterium Vibrio furnissi. Molecular cloning and analysis of the glucose and $\mathrm{N}$-Acetylglucosamine permeases. The Journal of Biological Chemistry, 271, n. 52, p. 33457-33467, 1996.

BOWEN, J.D.; STOLZENBACH, K.D.; CHISHOLM, S.W. Simulating bacterial clustering around phytoplankton cells in a turbulent ocean. Limnology and Oceanography, v. 38, 36$51,1993$. 
BOYER, J.N. Aerobic and anaerobic degradation and mineralization of ${ }^{14} \mathrm{C}-\mathrm{Chitin}$ by water Column and Sediment Inocula of the York River Estuary, Virginia. Applied and Environmental Microbiology, v. 60, p.174-179, 1994.

BOZAL, N.; MONTES, M. J.; TUDELA, E.; JIMENEZ, F.; GUINEA, J. Shewanella frigidimarina and Shewanella livingstonensis sp. nov. isolated from Antarctic coastal areas. International Journal of Systematic and Evolutionary Microbiology, v. 52, p. 195-205, 2002.

BRAGA, E.S.; MULLER, T.J. Observation of regeneration of nitrate, phosphate and silicate during upwelling off Ubatuba, Brazil, $23^{\circ}$ S. Continental Shelf Research, v. 18, p. 915-922, 1998.

BRAGA, E.S; NIENCHESKI, L.F.H. Composição das massas de água e seus potenciais produtivos na área entre o Cabo de São Tomé (RJ) e o Chuí (RS). In: ROSSIWONGTSCHOWSKI, C.; MADUREIRA, L.S.P. (Ed.). O ambiente oceanográfico da plataforma continental e do talude na região Sudeste-Sul do Brasil. São Paulo: EDUSP, 2006. p. 161-218.

BREDHOLDT, H.; GALATENKO, O.A; ENGELHARDT, K.; FJAERVIK, E.; TEREKHOVA, L.P.; ZOTCHEV, S.B. Rare actinomycete bacteria from the shallow water sediments of the Trondheim fjord, Norway: isolation, diversity and biological activity. Environmental microbiology, v. 9, n. 11, p. 2756-2764, 2007.

BRETTAR, I.; CHRISTEN, R.; HOFLE, M. G. Rheinheimera baltica gen. nov., sp. nov., a blue-coloured bacterium isolated from the central Baltic Sea. International Journal of Systematic and Evolutionary Microbiology, v. 52, p. 1851-1857, 2002.

BRETTAR, I.; CHRISTEN, R.; HOFLE, M. G. Rheinheimera perlucida sp. nov., a marine bacterium of the Gammaproteobacteria isolated from surface water of the central Baltic Sea. International Journal of Systematic and Evolutionary Microbiology, v. 56, p. 2177-2183, 2006.

BRZEZINSKA, M. S.; DONDERSKI, W. Occurrence and Activity of the Chitinolytic Bacteria of Aeromonas Genus. Polish Journal of Environmental Studies, v. 10, n. 1, 27-31, 2001.

BRZEZINSKA, M. S.; LALKE-PORCZYK， E.; DONDERSKI， W.; WALCZAK, M. Occurrence and Activity of Microorganisms in Shrimp Waste. Current Microbiology, v. 57, p. $580-587,2008$

BUCK, J.D. Nonstaining (KOH) Method for determination of Gram Reactions of Marine Bacteria. Applied and Environmental Microbiology, v. 44, n. 4, p. 992-993, 1982.

BULL, A. T.; MARRS, B.L.; KURANE, R. Biotechnology for clean industrial products and processes - Towards industrial sustainability. In:__ (Ed.). Paris: Organisation for Economic Cooperation and Development, 1998. p. 1-200.

BULL, A.T.; STACH, J.E.; WARD, A.C.; GOODFELLOW, M. Marine actinobacteria: perspectives, challenges, future directions. Antonie van Leeuwenhoek, v. 87, p. 65-79, 2005. 
CAMPBELL, L.L.; WILLIAMS, O.B. A study of chitin-decomposing micro-organisms of marine origin. Journal of General Microbiology, v. 5, n. 5, p. 894-905, 1951.

CARLSTROM, D. The Crystal Structure of Alpha-Chitin (Poly-N-Acetyl-D-Glucosamine). Journal of Biophysical and Biochemical Cytology, v.3, n.5, p. 669-683, 1957.

CARMAN, K.R.; DOBBS, F.C. Epibiotic microorganisms on copepods and other marine crustaceans. Microscopy Research and Technique, v. 37, p. 116-135, 1997.

CASTRO FILHO, B.M. Wind driven currents in the Chanel of São Sebastião: winter 1979. Boletim do Instituto Oceanográfico, v. 38, p. 111-132. 1990.

CASTRO FILHO, B.M.; LORENZZETTI, J.A.; SILVEIRA, I.C.A.; MIRANDA, L.B. Estrutura termohalina e circulação na região entre o cabo de São Tomé (RJ) e o Chuí (RS). In: ROSSI-WONGTSCHOWSKI, C.; MADUREIRA, L.S.P. (Ed.). O ambiente oceanográfico da plataforma continental e do talude na região Sudeste-Sul do Brasil. São Paulo: EDUSP, 2006, p. 121-160.

CASTRO FILHO, B.M.; MIRANDA, L.B.; MIYAO, S.Y. Condições hidrográficas na Plataforma Continental ao largo de Ubatuba: variações sazonais e em média escala. Boletim do Instituto Oceanográfico, v. 35, n. 2, p. 135-151, 1987.

CHANG, S.; CHEN, W.; WANG, J.; WU, M. Chitinilyticum aquatile gen. nov., sp. nov., a chitinolytic bacterium isolated from a freshwater pond used for Pacific white shrimp culture. International Journal of Systematic and Evolutionary Microbiology, v. 57, p. 2854-2860, 2007.

CHEN, H.; CHEN, K. Isolation of chitinolytic bacteria and their hydrolytic activity on shrimp shells. Proceedings of the National Science Council, Republic of China. Part B, v. 15, n. 4, p. 233-239, 1991.

CHIMETTO, L.A.; BROCCHI, M.; GONDO, M.; THOMPSON, C.C.; GOMEZ-GIL, B.; THOMPSON, F.L. Genomic diversity of vibrios associated with the Brazilian coral Mussismilia hispida and its sympatric zoanthids (Palythoa caribaeorum, Palythoa variabilis and Zoanthus solanderi). Journal of Applied Microbiology, v. 106, n. 6, p. 1818-1826, 2009.

CHOI, J.H.; IM, W.T.; YOO, J.S.; LEE, S.M.; MOON, D.S.; KIM, H.J.; RHEE, S.K.; ROH, D.H. Paenibacillus donghaensis sp. nov., a xylan-degrading and nitrogen-fixing bacterium isolated from East Sea sediment. Journal of Microbiology and Biotechnology, v. 18, n. 2, p. 189-193, 2008.

CIAPINA, L.P. Diferenciação genômica de bactérias gram-negativas e gram-positivas pela análise do gene 16S rDNA e rep-PCR.113 f. Dissertação (Mestrado em Agronomia) Faculdade de Ciências Agrárias e Veterinárias do Campus Jaboticabal-UNESP, São Paulo, 1997.

CLARKE, P.H.; TRACEY, M.V. The occurrence of chitinase in some bacteria. Journal of General Microbiology, v. 14, n. 1, p. 188-196, 1956. 
CODY, R.M. Distribution of Chitinase and Chitobiase in Bacillus. Current Microbiology, v. 19, p. 201-205, 1989.

CODY, R.M.; DAVIS, N.D.; LIN, J.; SHAW, D. Screening microorganisms for chitin hydrolysis and production of ethanol from amino sugars. Biomass, v. 21, n. 4, p. 285-295, 1990.

COHEN-KUPIEC, R.; CHET, I. The molecular biology of chitin digestion. Current Opinion in Biotechnology, v. 9, p. 270-277, 1998.

COLWELL, R.R. A voyage of discovery: cholera, climate and complexity. Environmental Microbiology, v. 4, n. 2, p. 67-69, 2002.

COLWELL, R.R. Global climate and infectious disease: the cholera paradigm. Science. 274, p. 2025-2031, 1996.

COLWELL, R.R. Microbial diversity: the importance of exploration and conservation. Journal of Industrial Microbiology \& Biotechnology, v. 18, p. 302-307, 1997.

COMB, D.G.; ROSEMAN, S. Glucosamine metabolism. IV Glucosamine-6-phosphate deaminase. The Journal of Biological Chemistry, v. 232, p. 807-827, 1958.

COMPANHIA DE TECNOLOGIA DE SANEAMENTO AMBIENTAL. Relatório de balneabilidade das praias Paulistas. São Paulo: CETESB, 2004. p. 331.

COMPANHIA DE TECNOLOGIA DE SANEAMENTO AMBIENTAL. Relatório de qualidade das águas litorâneas do estado de São Paulo. São Paulo: CETESB, 2008. 294 p.

CONSELHO NACIONAL DO MEIO AMBIENTE. Resolução $n^{\circ}$ 274, 29 de Novembro de 2000.

COTTRELL, M.T.; MOORE, J.A.; KIRCHMAN, D.L. Chitinases from Uncultured Marine Microorganisms. Applied and Environmental Microbiology, v. 65, n. 6., p. 2553-2557, 1999.

COTTRELL, M.T.; WOOD, D.N.; YU, L.; KIRCHMAN, D.L. Selected chitinase genes in cultured and uncultured marine bacteria in the $\alpha$ - and $\beta$ - subclasses of the Proteobacteria. Applied and Environmental Microbiology, v. 66, n. 3, p. 1195-1201, 2000.

CUNHA, M.A.; ALMEIDA, M.A.; ALCANTARA, F. Short-term responses of the natural planktonic bacterial community to the changing water properties in an estuarine environment: ectoenzymatic activity, glucose incorporation and biomass production. Marine Ecology, v. 42, p. 69-79, 2001.

DAHIYA, N.; TEWARI, R.; TIWARI, R.P.; HOONDAL, G.S. Production of an antifungal chitinase from Enterobacter sp. NRG4 and its application in protoplast production. World Journal of Microbiology and Biotechnology, v. 21, p. 1611- 1616, 2005.

DAS, S.; LYLA, P.S.; KHAN, A. Marine microbial diversity and ecology: importance and future perspectives. Current Science, v. 90, n.10, p. 1325-1332, 2006. 
de BRUIJN F. J. Use of Repetitive (Repetitive Extragenic Palindromic and Enterobacterial Repetitive Intergeneric Consensus) Sequences and the Polymerase Chain Reaction To Fingerprint the Genomes of Rhizobium meliloti Isolates and Other Soil Bacteria. Applied and Environmental Microbiology, v. 58, n. 7., p. 2180-2187, 1992.

DEANE, E.E.; WHIPPS, J.M.; LYNCH, J.M.; PEBERDY, J.F. The purification and characterization of a Trichoderma harzianum exochitinase. Biochimica et Biophysica Acta, v. 1383, v. 1, p. 101-110, 1998.

DeLONG, E. F.; FRANKS, D. G.; ALLDREDGE, A. L. Phylogenetic diversity of aggregateattached vs. free-living marine bacterial assemblages. Limnology and Oceanography, v. 38, n. 3, v. 924-934, 1993.

DeLONG, E.F. Microbial seascapes revisited. Current Opinion in Microbiology , v. 4, p. 290-295, 2001.

DeLONG, E.F.; KARL, D.M. Genomic perspectives in microbial oceanography. Nature, v. 437, p. 336-342, 2005.

DeMARCO, J.L.; LIMA, C.L.H.; DE SOUSA, M.V.; FELIX, C.R. A Trichoderma harzianum chitinase destroys the cell walls of the phytopathogen Crinipellis perniciosa, the casual agent of the witches broom disease of cocoa. World Journal of Microbiology and Biotechnology, v. 16, n. 4, p. 383-386, 2000.

DOMBEK, P. E.; JOHNSON, L. K.; ZIMMERLEY, S. T.; SADOWSKY, M.J. Use of Repetitive DNA Sequences and the PCR To Differentiate Escherichia coli Isolates from Human and Animal Sources. Applied and Environmental Microbiology, v. 66, n. 6, p. 2572-2577, 2000.

DONDERSKI W. Chitinolytic bacteria in water and bottom sediments of two lakes of different trophy. Acta Microbiologica Polonica, v. 33, n. 2, p. 163-170, 1984.

DONDERSKI W.; TRZEBIATOWSKA, M. Influence of Physical and Chemical Factors on the Activity of Chitinases Produced by Planktonic Bacteria Isolated from Jeziorak Lake. Polish Journal of Environmental Studies, v. 9, n. 2, p. 77-82, 2000.

DUMONTET, S.; KROVACEK, K.; SVENSON, S.B.; PASQUALE, V., BALODA, S.B., FIGLIUOLO, D., Prevalence and diversity of Aeromonas and Vibrio spp. in coastal waters of Southern Italy. Comparative Immunology, Microbiology and Infectious Disease, v. 23, p. 53-72, 2000.

EINBU, A. Characterisation of chitin and a study of its acid-catalysed hydrolysis. Tese (Doutorado) - Norwegian University of Science and Technology, Noruega, 2007.

FENICE, M.; GALLO, A. M.; JUAREZ-JIMENEZ, B.; GONZALEZ-LOPEZ, J. Screening for extracellular enzyme activities by bacteria isolated from samples collected in the Tyrrhenian sea. Annals of Microbiology, v. 57, n.1, p. 93-99, 2007. 
FERA , M.T.; MAUGERI, T.L.; GUGLIANDOLO, C.; BONANNO, D.; LA CAMERA, E.; PAPASERGI, S.; CARBONE, M. Occurrence of Burkholderia cepacia complex, Ralstonia and Pandoraea species DNAs in the coastal environment of the Straits of Messina (Italy). Marine Pollution Bulletin, v. 54, n. 6, p. 803-808, 2007.

FERNÁNDEZ-GARAYZÁBAL, J.F.; DOMINGUEZ, L.; PASCUAL, C.; JONES, D.; COLLINS, M.D. Phenotypic and phylogenetic characterization of some unknown coryneform bacteria isolated from bovine blood and milk: description of Sanguibacter gen.nov. Letters in Applied Microbiology, v. 20, n. 2, p. 69-75, 1995.

FERREIRA, Z. C. A. Ecossistemas costeiros. In: ARRUDA, M.B. (Ed.). Ecossistemas brasileiros. Brasília, IBAMA. p. 38-44. 2001.

FLEURI, L. F.; SATO, H. H. Produção, purificação, clonagem e aplicação de enzimas líticas. Química Nova, v. 28, n. 5, p. 871-879, 2005.

FLYG, C.; BOMAN, H.G. Drosophila genes cut and miniature are associated with the susceptibility to infection in Serratia marcescens. Genetical Research, v. 52, n. 1, p. 51-56, 1988.

FONTES, M.L.S.; ABREU, P.C. Spatiotemporal Variation of Bacterial Assemblages in a Shallow Subtropical Coastal Lagoon in Southern Brazil. Microbial Ecology, v. 58, n. 1, p.140-152, 2009.

FOX, G.E.; WISOTZKEY, J.D.; JURTSHUK, P. J. How close is close: 16S rRNA sequence identity may not be sufficient to guarantee species identity. International Journal of Systematic and Evolutionary Microbiology, v. 42, p. 166-170, 1992.

FRÄNDBERG, M.; SCHNÜRER , J. Chitinolytic properties of Bacillus pabuli K1. Journal of Applied Microbiology, v. 76, p. 361-367, 1994b.

FRÄNDBERG, M.; SCHNÜRER , J. Evaluation of a chromogenic chito-oligosaccharide analogue, p-nitrophenyl- $\beta$-D-N,N'-diacetylchitobiose, for the measurement of the chitinolytic activity of bacteria. Journal of Applied Microbiology, v. 76, n.3, p. 259-263, 1994a.

FUKASAWA, S.; ARAI, M.; WADA, T.; SHIMA, H.; KURATA, M. Some properties of a chitinase from a Marine Luminous Bacterium, Vibrio fischeri strain COT-A136. Chemical \& Pharmaceutical Bulletin, v. 40, n. 6, p. 1631-1633, 1992.

FUKUMOTO, M.M. Caracterização da sedimentação atual e reconstituição da história deposicional recente na Baía de Santos, a partir das características composicionais e isotópicas da matéria orgânica. 109 f. Dissertação (Mestrado em Oceanografia) - Instituto Oceanográfico, Universidade de São Paulo, São Paulo, 2003.

FUNDAÇÃO DE ESTUDOS E PESQUISAS AQUÁTICAS. Diagnóstico ambiental oceânico e costeiro das regiões sul e sudeste do Brasil. São Paulo: FUNDESPA, 1994. v. 3.

FURTADO, V. V. Sedimentação quaternária no Canal de São Sebastião. Publicação especial do Instituto Oceanográfico, v. 11, p. 27-35, 1995. 
FURUKAWA, K.; MATSUMURA, F.; TONOMURA, K. Alcaligenes and Acinetobacter strains capable of degrading polychlorinated biphenyls. Agricultural and Biological Chemistry, v. 42, p. 543-548, 1978.

GAETA, S.A.; RIBEIRO, S.M.S.; METZLER, P.M.; FRANCOS, M.S.; ABE, D.S. Environmental forcing on phytoplankton biomass and primary productivity of the coastal ecosystem in Ubatuba region, southern Brazil. Revista Brasileira de Oceanogafia, v. 47, p. 11-27, 1999.

GARCIA, E. Assessment of endo-1,4-beta-D-glucanase activity by a rapid colorimetric assay using disodium 2,2' bicinchoninate. Journal of Food Biochemistry , v. 17, 135-145, 1993.

GETCHELL, R.G. Bacterial shell disease in crustaceans: a review. Journal of Shellfish Research, v. 8, p. 1-6, 1989.

GHOSH, S.K.; FIELD, J.; FRISARDI, M.; ROSENTHAL, B.; MAI, Z., ROGERS, R., SAMUELSON, J. Chitinase secretion by encysting Entamoeba invadens and transfected Entamoeba histolytica trophozoites: Localization of secretory vesicles, endoplasmic reticulum, and golgi apparatus. Infection and Immunity, v. 67, n. 6, p. 3073-3081, 1999.

GIANSANTI, A.; BOCCHIERI, M.; ROSATO, V.; MUSUMECI, S. A fine functional homology between chitinases from host and parasite is relevant for malaria transmissibility. Parasitology Research, v. 101, n. 3, p. 639-645, 2007.

GIOVANNONI, S.; RAPPE, M. Evolution, diversity and molecular ecology of marine prokaryotes. In: KIRCHMAN, D. L. (Ed.). Microbial ecology of the oceans. New York: John Wiley \& Sons, 2000. p. 47-84.

GOFFINET, G. Production and biodegradation of chitin in marine environments. In: GIRAUD-GUILLE, M.M. (Ed). Chitin in life sciences. Lyon: European Chitin Society, 1996. p. 53-65.

GONZALEZ, A.M.; PARANHOS, R.; LUTTERBACH, M.S. Heterotrophic bacteria abundances in Rodrigo de Freitas Lagoon (Rio de Janeiro, Brazil). Brazilian Journal of Microbiology, v. 37, p. 428-433, 2006.

GOODAY, G. W. The ecology of chitin degradation. Advances in Microbial Ecology, v. 11, p. $387-430.1990$

GOODAY, G.W. Diversity of roles of chitinases in nature. In: ZAKARIA, M.B.; WAN MUDA, W.M.; ABDULlAH, M.P. (Ed.). Chitin and Chitosan. Malaysia: Penerbit Universiti Kebangsaan, 1995. p. 191-202.

GOPALAN, V.H.; YOUNG, J.S. Incidence of Shell disease in the New York Bight. Marine Pollution Bulletin, v. 6, n. 10, p. 149-153, 1975.

GRAHAM, L.S.; STICKLEN, M.B. Plant chitinases. Canadian Journal of Botany, v. 72, p. 1057-1083, 1994. 
GRIMONT, F.; GRIMONT, P. A. D. The genus Serratia. In: BALOWS, A.; TRUSPER, H.; DWORKIN, M.; HARDER, W.; SCHLEIFER, K.-H. (Ed.) The Prokaryotes, New York: Springer, 1992, p. 2822-2848.

GÜRTLER, V.; MAYALL, B.C. Genomic approaches to typing, taxonomy and evolution of bacterial isolates. International Journal of Systematic and Evolutionary Microbiology, v. 51, p. 3-16, 2001.

HACKMAN, R. H.; GOLDBERG, M. Studies on Chitin. VI. Nature of Alpha- and BetaChitins. Australian Journal of Biological Sciences, v.18, n. 4, p. 935-941, 1965.

HAKI, G. D.; RAKSHIT, S. K. Developments in industrially important thermostable enzymes: a review. Bioresource Technology, v. 89, n. 1, p. 17-34, 2003.

HALL, T. A. BioEdit: a user-friendly biological sequence alignment editor and analysis program for Windows 95/98/NT. Nucleic Acids Symposium Series, v. 41, p. 95-98, 1999.

HAN, Y.; YANG, B.; ZHANG, F.; MIAO, X.; LI, Z. Characterization of Antifungal Chitinase from Marine Streptomyces sp. DA11 Associated with South China Sea Sponge Craniella australiensis. Marine Biotechnology, v. 11, p. 132-140, 2009.

HARARI, J.; CAMARGO, R.; CACCIARI, P.L. Implantação de um sistema de previsão de marés e de correntes de maré na Baixada Santista através do modelo numérico tridimensional. Relatório Técnico do Instituto Oceanográfico, v. 45, p. 1-21, 1999.

HARMAN, G.E; HAYES, C.K.; LORITO, M.; BROADWAY, R.M; DI PIETRO, A; PETERBAUER, C.; TRONSMO, A. Chitinolytic enzymes of Trichoderma harzianum: purification of chitobiosidase and endochitinase. Phytopathology, v. 83, n. 3, p. 313-318, 1993.

HARTL, D.; HE, C.H.; KOLLER, B.; Da SILVA, C.A.; KOBAYASHI, Y.; LEE, C.G.L.; FLAVELL, R.A.; ELIAS, J.A. Acid Mammalian Chitinase Regulates Epithelial Cell Apoptosis via a Chitinolytic-Independent Mechanism. The Journal of Immunology, v. 182, p. 5098-5106, 2009.

HEIDELBERG, J. F.; HEIDELBERG, K. B.; COLWELL, R. R. Bacteria of the $\gamma$-Subclass Proteobacteria Associated with Zooplankton in Chesapeake Bay. Applied and Environmental Microbiology, v. 68, n. 11, p. 5498-5507, 2002.

HEILMANN, C.; SCHWEITZER, O.; GERKE, C.; VANITTANAKOM, N.; MACK, D.; GOTZ, F. Molecular basis of intercellular adhesion in the biofilm-forming Staphylococcus epidermidis. Molecular Microbiology, v. 20, 1083-1091, 1996.

HENRISSAT, B. A classification of glycosyl hydrolases based on amino acid sequence similarities. The Biochemical Journal, v. 280, p. 309-316, 1991.

HENRISSAT, B.; BAIROCH, A. New families in the classification of glycosyl hydrolases based on amino acid sequences similarities. The Biochemical Journal, v. 293, p. 781-788, 1993. 
HERTH, W.; MULISH, M.; ZUGENMAIER, P. Comparison of chitin fibril structure and assembly in three unicellular organisms. In: MUZZARELLI, R.; JEUNIAUX, C.; GOODAY, G. (Ed.). Chitin in Nature and Technology. New York: Plenum Press, 1986. p. 107-120.

HERWIG, R.P.; PELLERIN, N.B.; IRGENS, R.L.; MAKI, J.S.; STALEY, J.T. Chitinolytic bacteria and chitin mineralization in the marine water and sediments along the Antartic Peninsula. FEMS Microbiology Ecology, v. 53, p. 101-112, 1988.

HERWIG, R.P.; STALEY, J.T. Anaerobic bacteria from the digestive tract of North Atlantic fin whales (Balaenoptera physalus). FEMS Microbiology Letters, v. 38, n. 6, p. 361-371, 1986.

HIRAGA, K.; SHOU, L.; KITAZAWA, M.; TAKAHASHI, S.; SHIMADA, M.; SATO, R.; ODA, K. Isolation and characterization of chitinase from a flake chitin degrading marine bacterium, Aeromonas hydrophila $\mathrm{H}-2330$. Bioscience, Biotechnology, and Biochemistry, v. 61, p. 174-176, 1997.

HIRANO, S.; KOISHIBARA, Y.; KITAURA, S.; TANEKO, T.; TSUCHIDA, H.; MURAE, K.; YAMAMOTO, T. Chitin biodegradation in sand dunes. Biochemical Systematics and Ecology, v. 19, p. 379-384, 1991.

HIRANO, S.; NAGAO, N. An Improved Method for the Preparation of Colloidal Chitin by using Methanesulfonic Acid. Agricultural and Biological Chemistry, v. 52, n. 8, 2111$2112,1988$.

HIRONO, I.; YAMASHITA, M.; AOKI, T. Molecular cloning of chitinase genes from Vibrio anguillarum and $V$. parahaemolyticus. Journal of Applied Microbiology, v. 84, n. 6, p. 1175-1178, 1998.

HOBEL, C.F.; MARTEINSSON, V.T.; HREGGVIDSSON, G.O.; KRISTJÁNSSON, J.K. Investigation of the microbial ecology of intertidal Hot Springs by using diversity analysis of 16S rRNA and chitinase genes. Applied and Environmental Microbiology, v. 71, n. 5, p. 2771-2776, 2005.

HOLLAK, C. E. M.; VAN WEELY, S.; VAN OERS, M. H. J.; AERTS, J. M. F. G. Marked Elevation of Plasma Chitotriosidase Activity: A Novel Hallmark of Gaucher Disease. The Journal of Clinical Investigation, v. 93, n. 3, p. 1288-1292, 1994.

HOLlOWAY, B. Pseudomonas in the late twentieth century. In: GALLI, E.; SILVER, S.; WITHOLT, B. (Ed.) Pseudomonas Molecular Biology and Biotechnology. Washington, DC: American Society for General Microbiology, 1992, p. 1-8.

HOOD, M.A.; MEYERS, S.P. Rates of chitin Degradation in an Estuarine Environment. Journal of the Oceanographical Society of Japan, v. 33, p. 328-334, 1977.

HOSTER, F.; SCHMITZ, J.E.; DANIEL, R. Enrichment of chitinolytic microorganisms: isolation and characterization of a chitinase exhibiting antifungal activity against phytopathogenic fungi from a novel Streptomyces strain. Applied Microbiology and Biotechnology, v. 66, p. 434-442, 2005. 
HOWARD, M.B.; EKBORG, N.A.; WEINER, R.M.; HUTCHESON, S.W. Detection and characterization of chitinases and other chitin-modifying enzymes. Journal of Industrial Microbiology and Biotechnology, v. 30, p. 627-635, 2003a.

HOWARD, M.B.; EKBORG, N.A; TAYLOR, L.E.; WEINER, R.M.; HUTCHESON, S.W. Genomic analysis and initial characterization of the chitinolytic system of Microbulbifer degradans strain 2-40. Journal of Bacteriology, v. 185, n. 11, p. 3352-3360, 2003b.

HUANG, I. H.; CHEN, C.J.; SU, Y. C. Production of chitinolytic enzymes from a novel species of Aeromonas. Journal of Industrial Microbiology, v. 17, p. 89-95, 1996.

HUANG, Y.; DAI, X.; HE, L.; WANG, Y.N.; WANG, B.J.; LIU, Z.; LIU, S.J. Sanguibacter marinus sp. nov., isolated from coastal sediment. International Journal of Systematic and Evolutionary Microbiology, v. 55, p. 1755-1758, 2005.

HUNT, D. E.; GEVERS, D.; VAHORA, N. M.; POLZ, M. F. Conservation of the Chitin Utilization Pathway in the Vibrionaceae. Applied and Environmental Microbiology, v. 74, n. 1, p. 44-51, 2008.

HUQ, A.; COLWELL, R. R.; RAHMAN, R.; ALI, A.; CHOWDHURY, M. A. R.; PARVEEN, S.; SACK, D.A; RUSSEK-COHEN, E. Detection of Vibrio cholerae O1 in the aquatic environment by fluorescent-monoclonal antibody and culture methods. Applied and Environmental Microbiology, v. 56, n. 8, p. 2370-2373, 1990.

HUQ, A.; COLWELL, R.R. Environmental factors associated with emergence of disease with special reference to cholera. Eastern Mediterranean Health Journal, v. 2, p. 37-45, 1996.

HUQ, A.; SMALL, E. B.; WEST, P. A.; HUQ, M. I.; RAHMAN, R., COLWELL, R. R. Ecological relationship between Vibrio cholerae and planktonic crustacean copepods. Applied Environmental Microbiology, v. 45, n. 1, p. 275-283, 1983.

ILLUM, L. Chitosan and its use as a pharmaceutical excipient. Pharmacological Research, v. 15, n. 9, p. 1326-1331, 1998.

ISHII, S.; SADOWSKY, M.J. Applications of the rep-PCR DNA fingerprinting technique to study microbial diversity, ecology and evolution. Environmental Microbiology, v. 11, n. 4, 733-740, 2009.

ISLAM, M.S. Effect of various biophysicochemical conditions on toxigenicity of Vibrio cholerae 01 during survival with a green alga, Rhizoclonium fontanum, in an artificial aquatic environment. Canadian Journal of Microbiology, v.36, n. 7, p. 464-468, 1990.

ISLAM, M.S.; RAHIM, Z.; ALAM, M.J.; BEGUM, S.; MONIRUZZAMAN, S.M.; UMEDA, A.; AMAKO, K.; ALBERT, M.J.; SACK, R.B.; HUQ, A.; COLWELL, R.R. Association of Vibrio cholerae $\mathrm{O} 1$ with the cyanobacterium, Anabaena sp., elucidated by polymerase chain reaction and transmission electron microscopy. Transactions of the Royal Society of Tropical Medicine and Hygiene, v. 93, n. 1, p. 36-40, 1999.

ITOI, S.; KANOMATA, Y.; KOYAMA, Y. ; KADOKURA, K.; UCHIDA, S.; NISHIO, T.; OKU, T.; SUGITA, H. Identification of a novel endochitinase from a marine bacterium Vibrio 
proteolyticus strain No. 442. Biochimica et Biophysica Acta, v. 1774, n. 9, p. 1099-1107, 2007.

JACKSON, C.R.; FOREMAN, C.M.; SINSABAUGH, R.L. Microbial enzyme activities as indicator of organic matter processing rates in a lake Erie coastal wetland. Freshwater Biology, v. 34, p. 329-342, 1995.

JACKSON, G.A. Simulation of bacterial attraction and adhesion to falling particles in an aquatic environment. Limnology and Oceanography, v. 34, p. 514-530, 1989.

JANG, M.S.; LEE, Y.M.; CHO, Y.S.; CHOI, Y.L.; KIM, C.H.; LEE, Y.C. Overexpression and characterization of a novel chitinase gene from a marine bacterium Pseudomonas sp. BK1. Indian Journal of Biochemistry and Biophysics, v. 42, n. 6, p.339-344, 2005.

JENSEN, P. R.; FENICAL, W. Marine bacterial diversity as a resource for novel microbial products. Journal of Industrial Microbiology and Biotechnology, v. 17, p. 346-351, 1996.

JENSEN, P. R.; FENICAL, W. Strategies for the discovery of secondary metabolites from marine bacteria: ecological perspectives. Annual Review of Microbiology, v. 48, p. 559-584, 1994.

JEUNIAUX, C. Chitinolytic systems in the digestive tract of vertebrates: a review. In: MUZZARELLI, R.A.A. (Ed.). Chitin Enzymology. Italy: European Chitin Society, 1993. p. 233-244.

JEUniaUX, C.; GOODAY, G. (Ed.). Chitin in Nature and Technology. New York: Plenum Press, 1986. p. 107-120.

JOHNSTONE, J. (Ed.). Conditions of Life in the Sea. Cambridge: University Press, 1908. p. 332.

JORGENSEN, N.O.G.; KROER, N.; COFFIN, K.B.; HOCH, M.P. Relations between bacterial nitrogen metabolism and growth efficiency in an estuarine and an open-water ecosystem. Aquatic Microbiology, 18, 247-261, 1999.

JUAREZ-JIMENEZ, B.; RODELAS, B.; MARTINEZ-TOLEDO, M, V.; GONZALEZLOPEZ, J.; CROGNALE, S.; GALLO, A. M.; PESCIAROLI, C.; FENICE, M. Production of chitinolytic enzymes by a strain (BM17) of Paenibacillus pabuli isolated from crab shells samples collected in the east sector of central Tyrrhenian Sea. International Journal of Biological Macromolecules, v. 43, p. 27-31, 2008.

JUKES, T.H.; CANTOR, C.R. Evolution of protein molecules. In: MUNRO, H.N. (Ed). Mammalian protein metabolism. New York: Academic Press, 1969. p. 21-132.

KARL, D.M. Microbial Oceanography: paradigms, processes and promise. Nature Reviews. Microbiology, v. 5, p. 759-769, 2007.

KARRER, P.; HOFMANN, A. Uber den enzymatischen Abbau von chitin und chitosan. Helvetica chimica Acta, v. 12, p. 616-637, 1929. 
KAWASE, T.; SAITO, A.; SATO, T.; KANAI, R.; FUJII, T.; NIKAIDOU, N.; MIYASHITA, K.; WATANABE, T. Distribution and Phylogenetic Analysis of Family 19 Chitinases in Actinobacteria. Applied and Environmental Microbiology, v. 70, n. 2, p. 1135-1144, 2004.

KAWASE, T.; YOKOKAWA, S.; SAITO, A.; FUJII, T.; NIKAIDOU, N.; MIYASHITA K, WATANABE T. Comparison of enzymatic and antifungal properties between family 18 and 19 chitinases from S. coelicolor A3(2). Bioscience, Biotechnology, and Biochemistry, v. 70, n. 4, p. 988-998, 2006.

KELECOM A. Chemistry of marine natural products: yesterday, today and tomorrow. Anais da Academia Brasileira de Ciências, v. 71, n. 2, p. 249-263, 1999.

KEYHANI, N.O.; ROSEMAN, S. The chitin catabolic in the marine bacterium Vibrio furnissii. Molecular cloning, isolation, and characterization of a periplasmic chitodextrinase. The Journal of Biological Chemistry, v. 271, n. 52, p. 33414-33424, 1996a.

KEYHANI N.O; ROSEMAN, S. The chitin catabolic cascade in the marine bacterium Vibrio furnissii. Molecular cloning, isolation, and characterization of a periplasmic $B-N-$ Acetylglucosaminidase. The Journal of Biological Chemistry, 271, n. 52, p. 33425-33432, $1996 b$.

KEYHANI, N.O.; LI, X.; ROSEMAN, S. Chitin Catabolism in the Marine Bacterium Vibrio furnissii. Identification and molecular cloning of a chitoporin. The Journal of Biological Chemistry, v. 275, n. 42, p. 33068-33076, 2000.

KEYHANI, N.O.; ROSEMAN, S. Physiological aspects of chitin catabolism in marine bacteria. Biochimica et Biophysica Acta, v. 1473, p. 108-122, 1999.

KEYHANI, N.O.; ROSEMAN, S. Wild-type Escherichia coli grows on the chitin disaccharide, $N, N^{\prime}$-diacetylchitobiose, by expressing the cel operon. Proceedings of the National Academy of Sciences of the United States of America, v. 94, n. 26, p. 1436714371, 1997.

KEYHANI, N.O; WANG, L.; LEE, Y.C.; ROSEMAN, S. The chitin catabolic cascade in the marine bacterium Vibrio furnissi. Characterization of an $N, N$ '- Diacetyl-chitobiose transport system. The Journal of Biological Chemistry, v. 271, n. 52, p. 33409-33413, 1996.

KIRCHMAN, D.; MITCHELL, R. Contribution of particle-bound bacteria to total microheterotrophic activity in five ponds and two marshes. Applied and Environmental Microbiology, v. 43, n. 1, p. 200-209, 1982.

KIRCHNER, M. Microbial colonization of copepod body surfaces and chitin degradation in the sea. Helgoland Marine Research, v. 49, p. 201-212, 1995.

KOBAYASHI, D. Y.; REEDY, R. M.; BICK, J.; OUDEMANS, P. V. Characterization of a chitinase gene from Stenotrophomonas maltophilia strain $34 \mathrm{~S} 1$ and its involvement in biological control. Applied and Environmental Microbiology, v. 68, p. 1047-1054, 2002. 
KOEUTH, T.; VERSALOVIC, J.; LUPSKI, J.R. Differential subsequence conservation of interspersed repetitive Streptococcus pneumoniae BOX elements in diverse bacteria. Genome Research, v. 5, p. 408-418, 1995.

KOKARE, C. R.; MAHADIK, K. R.; KADAM, S. S.; CHOPADE, B. A. Isolation, characterization and antimicrobial activity of marine halophilic Actinopolyspora species AH1 from the west coast of India Current Science, v. 86, p. 593-597, 2004.

KOLM, H.E.; ANDRETTA, L. Bacterioplankton in different tides of the Pereque tidal creek, Pontal do Sul, Parana, Brazil. Brazilian Journal of Microbiology, v. 34, p. 97-103, 2003

KONSTANTINIDIS, K.; TIEDJE, J.M. Prokaryotic taxonomy and phylogeny in the genomic era: advancements and challenges ahead. Current Opinion in Microbiology, v. 10, p. 504509, 2007.

KONSTANTINIDIS, K.T.; RAMETTE, A.; TIEDJE, J. M. The bacterial species definition in the genomic era. Philosophical Transactions of the Royal Society B, v. 361, p. 1929-1940, 2006.

KONSTANTINIDIS, K.T.; TIEDJE, J. M. Genomic insights into the species definition for prokaryotes. Proceedings of the National Academy of Sciences of the United States of America, v. 102, n. 7, p. 2567-2572, 2005a.

KONSTANTINIDIS, K.T.; TIEDJE, J. M. Towards a genome-based taxonomy for prokaryotes. Journal of Bacteriology, v. 187, p. 6258-6264, $2005 \mathrm{~b}$.

KROVACEK, K.; PASQUALE, V.; BALODA, S.B.; SOPRANO, V.; CONTE, M.; DUMONTET, S. Comparison of putative virulence factors in Aeromonas hydrophila strains isolated from the marine environment and human diarrheal cases in southern Italy. Applied and Environmental Microbiology, v. 60, p. 1379-1382, 1994.

KRSEK, M.; WELLINGTON, E.M.H. Assessment of chitin decomposer diversity within an upland grassland. Antonie Leeuwenhoek, v. 79, p. 261-267, 2001.

KUMAR, M. N. V. R. A review of chitin and chitosan applications. Reactive \& Functional Polymers, v. 46, p. 1-27, 2000.

KURITA, K. Controlled functionalization of the polysaccharide chitin. Progress in Polymer Science, v. 26, n. 9, p. 1921-1971, 2001.

KVINGE, T. On the special currents and water levels variations in the Channel of São Sebastião. Boletim do Instituto Oceanográfico, v. 16, p. 23-38, 1967.

LAGUERRE, G.; Van BERKUM, P.; AMARGER, N.; PREVOST, D. Genetic diversity of rhizobial symbionts isolated from legume species within the genera Astragalus, Oxytropis, and Onobrychis. Applied and Environmental Microbiology, v. 63, n.12, p. 4748-4758, 1997.

LAN, X.; OZAWA, N.; NISHIWARI, N.; KODAIRA, R.; OKAZAKI, M.; SHIMOSAKA, M. Purification, Cloning, and sequence analysis of $\beta-N$-Acetylglucosaminidase from the 
chitinolytic bacterium Aeromonas hydrophila strain SUWA-9. Bioscience, Biotechnology, and Biochemistry, v. 68, n. 5, p. 1082-1090, 2004.

LANE, D. J. 16S/23S rRNA sequencing. In: STACKEBRANDT, E. e OODFELLOW, M. (Ed.). Nucleic acid techniques in bacterial systematics. England: John Wiley \& Sons, Chichester, 1991. p. 115-163.

LECLEIR, G.R.; BUCHAN, A.; HOLLIBAUGH, J.T. Chitinase Gene Sequences Retrieved from Diverse Aquatic Habitats Reveal Environment-Specific Distributions. Applied and Environmental Microbiology, v. 70, n. 12, p. 6977-6983, 2004.

LECLEIR, G.R.; BUCHAN, A.; MAURER, J., MORAN, M.A., HOLLIBAUGH, J.T. Comparison of chitinolytic enzymes from an alkaline, hypersaline lake and an estuary. Environmental Microbiology, v. 9, n. 1, p. 197-205, 2007.

LI, Q.; WANG, F., ZHOU, Y., XIAO, X., Putative Exposed Aromatic and Hydroxyl Residues on the Surface of the N-Terminal Domains of Chi1 from Aeromonas caviae CB101 are Essential for Chitin Binding and Hydrolysis. Applied and Environmental Microbiology, v. 71, n. 11, p. 7559-7561, 2005.

LI, X.; ROSEMAN, S. The chitinolytic cascade in Vibrios is regulated by chitin oligosaccharides and a two-component chitin catabolic sensor/kinase. Proceedings of the National Academy of Sciences of the United States of America, v. 101, n. 2, p. 627-631, 2004.

LINDSAY, G.J.H.; GOODAY, G.W. Chitinolytic enzymes and the bacterial microflora in the digestive tract of cod, Gadus morhua. Journal of Fish Biology, v. 26, n. 3, p. 255-265, 1990.

LIU, M.; CAI, Q.X.; LIU, H.Z.; ZHANG B.H.; YAN, J.P.; YUAN, Z.M. Chitinolytic activities in Bacillus thuringiensis and their synergistic effects on larvicidal activity. Journal of Applied Microbiology, v. 93, p. 374-379, 2002.

LOISEAU, P.M.; BORIES, C.; SANON, A. The chitinase system from Trichomonas vaginalis as a potential target for antimicrobial therapy of urogenital trichomoniasis. Biomedicine \& Pharmacotherapy, v. 56, n. 10, p. 503-510, 2002.

LOUWS, F.J.; SCHNEIDER, M.; DE BRUIJN, F.J. Assessing genetic diversity of microbes using repetitive-sequence-based PCR (rep-PCR). In: TORANZOS, G. (Ed.) Nucleic Acid Amplifications Methods for the Analysis of Environmental Samples. Lancaster: Technomic Publishing Co., 1996. p. 63-94.

LUPSKI, J.R.; WEINSTOCK, G.M. Short, Interspersed repetitive DNA sequences in prokaryotic genomes. Journal of Bacteriology, v. 174, p. 4525-4529, 1992.

LYSENKO, O. Chitinase from Serratia marcescens and its toxicity to insects. Journal of Invertebrate Pathology, v. 27, p, 385-386, 1976.

MACDONELL, M. T.; COLWELL, R. R. Phylogeny of the Vibrionaceae, and recommendation for two new genera, Listonella and Shewanella. Systematic and Applied Microbiology, v. 6, p. 171-182, 1985. 
MAHIQUES, M.M. Dinâmica sedimentar atual nas enseadas da região de Ubatuba, Estado de São Paulo. Boletim do Instituto Oceanográfico, v. 43, n. 2, p. 111-122, 1995.

MAIDACK, B.L.; OLSEN, G.J.; LARSEN, N.; OVERBEEK, R.; McCAUGHEY, M.J.; WOESE, C.R. The ribosomal data base project (RDP). Nucleic Acids Research, v. 24, p. 82$85,1996$.

MANTELATTO, F. L. M.; FRANSOZO, A. Characterization of the physical and chemical parameters of Ubatuba Bay, northern coast of São Paulo State, Brazil. Brazilian Journal of Biology, v. 59, n. 1, p. 23-31, 1999.

MARTINS, C.C. Marcadores Orgânicos Geoquímicos em testemunhos de sedimento do Sistema Estuarino de Santos e São Vicente, SP: um registro histórico da introdução de hidrocarbonetos no ambiente marinho. 215 f. Tese (Doutorado em Oceanografia) Instituto Oceanográfico, Universidade de São Paulo, São Paulo, 2005.

MASCO, L.; HUYS, G.; GEVERS, D.; VERBRUGGHEN, L.; SWINGS, J. Identification of Bifidobacterium species using rep-PCR fingerprinting. Systematic and Applied Microbiology, v. 26, n. 4, p. 557-563, 2003.

MATSUO, Y.; KURITA, M.; PARK, J.K.; TANAKA, K.; NAKAGAWA, T.; KAWAMUKAI, M.; MATSUDA, H. Purification, Characterization and Gene Analysis of NAcetylglucosaminidase from Enterobacter sp. G-1. Bioscience, Biotechnology, and Biochemistry, v. 63, n. 7, p. 1261-1268, 1999.

McLELLAN, S.L. Genetic diversity of Escherichia coli isolated from Urban Rivers and Beach Water. Applied and Environmental Microbiology, v. 70, n. 8, p. 4658-4665, 2004.

MEDEIROS, P.M. Avaliação da origem de hidrocarbonetos em sedimentos marinhos de Santos e São Sebastião, utilizando-se hidrocarbonetos marcadores geoquímicos. $102 \mathrm{f}$. Dissertação (Mestrado em Oceanografia) - Instituto Oceanográfico, Universidade de São Paulo, São Paulo, 2000.

MEIBOM, K.L.; BLOKESCH, M.; DOLGANOV, N. A.; WU, C.; SCHOOLNIK, G. K. Chitin Induces Natural Competence in Vibrio cholerae. Science, v. 310, n. 5755, p. 1824 $1827,2005$.

MEIBOM, K.L.; LI, X.B.; NIELSEN, A.T.; WU, C.-Y.; ROSEMAN, S.; SCHOOLNIK, G.K. The Vibrio cholerae chitin utilization program. Proceedings of the National Academy of Sciences of the United States of America, v. 101, p. 2524-2529, 2004.

MEJÍA-SAULÉS, J.E.; WALISZEWSKI, K. N.; GARCIA, M. A.; CRUZ-CAMARILLO, R. The Use of Crude Shrimp Shell Powder for Chitinase Production by Serratia marcescens WF. Food Technology and Biotechnology, v. 44, n. 1, p. 95-100, 2006.

MENDES, F.M. Estrutura da comunidade macrozoobentônica na região de influência do Terminal Almirante Barroso (TEBAR) no Canal de São Sebastião (SP, Brasil). 75 f. Dissertação (Mestrado em Oceanografia) - Instituto Oceanográfico, Universidade de São Paulo, São Paulo, 2007. 
MENDES, J. C. Elementos de Estratigrafia. São Paulo: Editoria da Universidade de São Paulo, 1984. p. 566.

MENNA, P., PEREIRA, A.A.; BANGEL, E.V.; HUNGRIA, M. rep-PCR of tropical rhizobia for strain fingerprinting, biodiversity appraisal and as a taxonomic and phylogenetic tool. Symbiosis, v. 48, p. 1-3, 2009.

MERZENDORFER, H.; ZIMOCH, L. Chitin metabolism in insects: structure, function and regulation of chitin synthases and chitinases. The Journal of Experimental Biology, v. 206, p. 4393-4412, 2003.

METCALFE, A.C.; KRSEK, M.; GOODAY, G.W.; PROSSER, J.L.; WELLINGTON, E.M.H. Molecular analysis of a Bacterial Chitinolytic Community in an Upland Pasture. Applied and Environmental Microbiology, v. 68, n. 10, p. 5042-5050, 2002.

MIRELMAN, D. Microbial lectins and agglutinins. New York: Wiley-Interscience, 1986.

MONFORT, P.; BALEUX, B. Dynamics of Aeromonas hydrophila, Aeromonas sobria, and Aeromonas caviae in a sewage treatment pond. Applied and Environmental Microbiology, v. 56, p. 1999-2006, 1990.

MORAN, M. A.; RUTHERFORD, L. T.; HODSON, R. E. Evidence for indigenous Streptomyces populations in a marine environment determined with a $16 \mathrm{~S}$ rRNA probe. Applied and Environmental Microbiology, v. 61, p. 3695-3700, 1995.

MORGANTI, P.; MORGANTI, G. Chitin nanofibrils for advanced cosmeceuticals. Clinics in Dermatology, v. 26, p. 334-340. 2008.

MUDRYK, Z.; SKÓRCZEWSKI, P. Extracellular enzyme activity at the air-water interface of an estuarine lake. Estuarine, Coastal and Shelf Science, v. 59, n.1, 59-67, 2004.

MUYZER, G.; DE WAAL, E.C.; UITTERLINDEN, A.G. Profiling of complex microbial populations by denaturing gradient gel electrophoresis analysis of polymerase chain reactionamplified genes coding for 16S rRNA. Applied and Environmental Microbiology, v. 59, n. 3, p. 695-700, 1993.

MUYZER, G.; SMALLA, K. Application of denaturing gradient gel electrophoresis (DGGE) and temperature gradient gel electrophoresis (TGGE) in microbial ecology. Antonie van Leeuwenhoek, v.73, n.1, p. 127-141, 1998.

MUZZARELLI, R.A.A (Ed.). Chitin. Great Britain: Pergamon Press, Oxford, 1977. p. 1-309. MYERS, N. Environmental services of biodiversity. Proceedings of the National Academy of Sciences of the United States of America, v. 93, n. 7, p. 2764-2769, 1996.

NEUGEBAUER, E.; GAMUCHE, B.; DERCY, C.V.; BRZEZINSKI, R. Chitinolytic properties of Streptomyces lividans. Archives of Microbiology, v. 156, n.3, p. 192-197, 1990.

NO, H.K; MEYERS, S.P. Application of chitosan for treatment of wastewaters. Reviews of Environmental Contamination and Toxicology, v. 163, p. 1-27, 2000. 
NOMENCLATURE COMMITTEE OF INTERNATIONAL UNION OF BIOCHEMISTRY AND MOLECULAR BIOLOGY. Enzyme list. In: Enzyme nomenclature. San

Diego, California: Academic Press, 1992. p. 348-353.

NUBEL, U.; ENGELEN, B.; FELSKE, A.; SNAIDR, J.; WIESHUBER, A.; AMANN, R.I.; LUDWIG, W.; BACKHAUS, H. Sequence Heterogeneities of Genes Encoding 16S rRNAs in Paenibacillus polymyxa Detected by Temperature Gradient Gel Electrophoresis. Journal of Bacteriology, v. 178, n.19, p. 5636-5643, 1996.

OHNO, T.; ARMAND, S.; HATA, T.; NIKAIDOU, N.; HENRISSAT, B.; MITSUTOMI, M.; WATANABE, T. A Modular Family 19 Chitinase Found in the Prokaryotic Organism Streptomyces griseus HUT 6037. Journal of Bacteriology, v. 178, p. 5065-5070, 1996.

OLIVE, D.M.; BEAN, P. Principles and applications of methods for DNA based typing of microbial organisms. Journal of Clinical Microbiology, v. 37, p. 1661-1669, 1999.

ORIKOSHI, H.; NAKAYAMA, S.; MIYAMOTO, K.; HANATO, C.; YASUDA, M.; INAMORI, Y.; TSUJIBO, H. Roles of four chitinases (ChiA, ChiB, ChiC, and ChiD) in the chitin degradation system of marine bacterium Alteromonas sp. strain O-7. Applied and Environmental Microbiology, v. 71, n. 4, p. 1811-1815, 2005.

ORUNSI, N.A.; TRINCI, A.P.J. Growth of bacteria on chitin, fungal cell walls and fungal biomass, and the effect of extracellular enzymes produced by these cultures on the antifungal activity of amphotericin B. Microbios, v. 43, n. 172, p. 17-30, 1985.

OSAWA, R.; KOGA, T. An investigation of aquatic bacteria capable of utilizing chitin as the sole source of nutrients. Letters in Applied Microbiology, v. 21, p. 288-291, 1995.

OUTTRUP, H.; JORGENSEN, S.T. The importance of Bacillus species in the production of industrial enzymes. In: BERKLEY, R. (Ed.). Applications and systems of Bacillus and relatives, Blackwell Science, 2002. p. 206-218.

OVERDIJK, B.; STEIJN, G. J. V.; ODDS, F.C. Chitinase levels in guinea pig blood are increased after systemic infection with Aspergillus fumigatus. Glycobiology, v. 6, n. 6, p. 627-634, 1996.

PARANHOS, R.; ANDRADE, L.; MENDONÇA-HAGLER, L.C.; PFEIFFER, W.C. Coupling bacterial abundande with production in a polluted tropical coastal bay. In: FARIA, B.M.; FARJALLA, V.F.; ESTEVES, F.A. (Ed.) Aquatic Microbial Ecology in Brazil. Rio de Janeiro: PPGE-UFRJ, 2001. p. 117-132.

PARK, S.H.; LEE, J-H.; LEE, H.K. Purification and Characterization of Chitinase from a marine Bacterium, Vibrio sp. 98CJ11027. The Journal of Microbiology, v. 38, n. 4, p. 224229. 2000.

PATEL, A.B.; FUKAMI, K.; NISHIJAMA, T. Regulation of seasonal variability of aminopeptidase activities in surface and bottom waters of Uranouchi Inlet, Japan. Aquatic Microbial Ecology, v. 21, p. 139-149, 2000. 
PELLIZARI, V.H.; BEZBORODNIKOV, S.; QUENSEN III, J.F.; TIEDJE, J.M. Evaluation of Strains Isolated by Growth on Naphthalene and Biphenyl for Hybridization of Genes to Dioxygenase Probes and Polychlorinated Biphenyl-Degrading Ability. Applied and Environmental Microbiology, v. 62, n. 6, p. 2053-2058, 1996.

PEMBERTON, J.M.; KIDD, S.P.; SCHMIDT, R. Secreted enzymes of Aeromonas. FEMS Microbiology Letters, v. 152, n. 1, :1-10, 1997.

PIRES-VANIN, A.M.S.; MATSSURA, Y. Estrutura e função do ecossistema de plataforma continental da região de Ubatuba, Estado de São Paulo: uma introdução. Publicação Especial do Instituto Oceanográfico, v. 10, p. 1-8, 1993.

PISANO, M.A.; SOMMER, M.J.; TARAS, L. Bioactivity of chitinolytic actinomycetes of marine origin. Applied Microbiology and Biotechnology, v. 36, p. 553-555, 1992.

POPE, A.M.S.; DAVIS, D.A.L. The influence of carbohydrates on the growth of fungal pathogens in vitro and in vivo. Postgraduate Medical Journal, v. 55, p. 674-676, 1979.

POULICEK, M.; JEAUNIAUX, C. Chitin biomass in marine sediments. In: SKJAK-BRAEK, G.; ANTHONSEN, T.; SANDFORD, P. (Ed). Chitin and Chitosan, London: Elsevier Applied Science, 1988. p.151-155.

PRABAHARAN, M. Chitosan derivatives as promising materials for controlled drug delivery. Journal of Biomaterials Applications, v.23, n.1, p. 5-36, 2008.

PROSSER, J.I.; BOHANNAN, B.J.M.; CURTIS, T.P.; ELLIS, R.J; FIRESTONE, M.K.; FRECKLETON, R.P.; GREEN, J.L.; GREEN, L.E.; KILLHAM, K., LENNON, J.J.; OSBORN, M.; SOLAN, M.; van der GAST, C.J.; YOUNG, P.W. The role of ecological theory in microbial ecology. Nature Reviews Microbiology, v. 5, p. 384-392. 2007.

PRUZZO, C; VEZZULLI, L.; COLWELL, R.R. Global impact of Vibrio cholerae interactions with chitin. Environmental Microbiology, v. 10, n. 6, p. 1400-1410, 2008.

QIN, S.; WANG, H.B.; CHEN, H.H.; ZHANG, Y.Q; JIANG, C.L.; XU, L.H.; LI, W.J. Glycomyces endophyticus sp. nov., an endophytic actinomycete isolated from the root of Carex baccans Nees. International Journal of Systematic and Evolutionary Microbiology, v. 58, p. 2525-2528, 2008.

RADEMAKER, J. L. W.; LOUWS, F.J.; VERSALOVIC, J.V.; de BRUIJN, F.J. Characterization of the diversity of ecologically important microbes by rep-PCR genomic fingerprinting. In: KOWALCHUCK, G.A.; de BRUIJN, F.J.; HEAD, I, M.; AKKERMANS, A.D.L.; van ELSAS, J.D. (Ed.). Molecular Microbial Ecology Manual. Dordrecht, the Netherlands: Springer, p. 611-644, 2004.

RADEMAKER, J. L.W.; SAVELKOUL, P.H.M. PCR Amplification based microbial typing. In: PERSHING, D.H.; TENOVER, F.C.; VERSALOVIC, J.; TANG, Y.W.; UNGER, E.R.; RELMAN, D.A.; WHITE, T.J. (Ed.). Diagnostic Molecular Microbiology Principles and Applications. Washington: ASM Press, 2004. p. 197-221. 
RADEMAKER, J.L.W.; de BRUIJN, F.J. Characterization and classification microbes by rep-PCR genomic fingerprinting and computer assisted pattern analysis. In: CAETANOANOLLÉS, G.; GRESSHOFF, P.M. (Ed.). DNA Markes: protocols, applications and overviews. New York: J. Wiley \& Sons, 1997. p. 151-171.

RAMAIAH, N.; HILL, R.T.; CHUN, J.; RAVEL, J.; MATTÉ, M.H.; STRAUBE, W.L.; COLWELL, R.R. Use a chiA probe for detection of chitinase genes in bacteria from the Chesapeake Bay. FEMS Microbiology Ecology, v. 34, p. 63-71, 2000.

RAMÍREZ, M.G.; AVELIZAPA, L.I.R.; AVELIZAPA, N.G.R.; CAMARILLO, R.C. Colloidal chitin stained with Remazol Blue $\mathrm{R}^{\circledR}$, a useful substrate to select chitinolytic microorganisms and to evaluate chitinases. Journal of Microbiological Methods, v. 56, n. 2, p. 213-219, 2004.

RAY, G.C. Coastal-zone Biodiversity Patterns. BioScience, v. 41, p. 490-498, 1991.

REGUERA, G.; KOLTER, R. Virulence and the Environment: a Novel Role for Vibrio cholerae Toxin-Coregulated Pili in Biofilm Formation on Chitin. Journal of Bacteriology, v. 187, n. 10, p. 3551-3555, 2005.

REID, J. D.; OGRYDZIAK, D.M. Chitinase-Overproducing Mutant of Serratia marcescens. Applied and Environmental Microbiology, v. 41, n. 3, p. 664-669, 1981.

REIS, A.M.M.; ARAÚJO-Jr, S.D.; MOURA, R.L.; FRANCINI-FILHO, R.B.; PAPPAS-Jr, G.; COELHO, A.M.A.; KRUGER, R.H.; THOMPSON, F.L. Bacterial diversity associated with the Brazilian endemic reef coral Mussismilia braziliensis. Journal of Applied Microbiology, v. 106, n. 4, p. 1378-1387, 2009.

REISSING, J.; STROMINGER, J.; LELOIR, L. "A modified colorimetric method for the estimation of $\mathrm{N}$-acetylamino sugars. Journal of Biological Chemistry, v. 21, p. 959-967, 1955.

RINAUDO, M. Chitin and chitosan: Properties and applications. Progress in Polymer Science, v. 31, p. 603-632, 2006.

RIVERA, I. G.; CHOWDHURY, M. A. R.; HUQ, A.; JACOBS, D.; MARTINS, M. T.; COLWELL, R. R. Enterobacterial Repetitive Intergenic Consensus Sequences and the PCR to Generate Fingerprints of Genomic DNAs from Vibrio cholerae O1, O139, and Non-O1 Strains. Applied and Environmental Microbiology, v. 61, n. 08, p. 2898-2904, 1995.

RIVERA, I. G.; CHUN, J.; HUQ, A.; SACK, R.B.; COLWELL, R.R. Genotypes Associated with Virulence in Environmental Isolates of Vibrio cholerae. Applied and Environmental Microbiology, v. 67, n. 06, p. 2421-2429, 2001.

RIVERA, I.N.G.; RODRIGUES, C.P.; SOUZA, C.P. Microbiologia Aquática Marinha. In: MELO, I.S. e AZEVEDO, J.L. (Ed.). Microbiologia Ambiental. 2. ed. Jaguariúna: Embrapa, 2008. v. 1, p. 610-627.

ROBERTS, G. A. F. (Ed.) Chitin Chemistry. London: MacMillan Press, 1992. p. 350. 
ROBERTS, W.K.; SELITRENNIKOFF, C.P. Plant and Bacterial Chitinases differ in Antifungal Activity. Journal of General Microbiology, v. 134, n. 1, 169-176, 1988.

RODRIGUES D.F. Caracterização polifásica da biodiversidade de isolados degradadores de poluentes xenobióticos na Baixada Santista. 170 f. Dissertação (Mestrado em Ciências) - Instituto de ciências Biomédicas, Universidade de São Paulo, São Paulo, 2002.

RODRIGUEZ-KABANA, R.; GODOY, G.; MORGAN-JONES, G.; SHELBY, R.A. The determination of soil chitinase activity: Conditions for assay and ecological studies. Plant and Soil, v. 75, n. 1, p. 95-106, 1983.

ROGERS, M.E.; HAJMOVÁ, M.; JOSHI, M.B.; SADLOVA, J.; DWYER, D.M.; VOLF, P.; BATES, P.A. Leishmania chitinase facilitates colonization of sand fly vectors and enhances transmission to mice. Cellular Microbiology, v. 10, n. 6, p. 1363-1372, 2008.

ROMANENKO, L. A.; UCHINO, M.; FALSEN, E.; ZHUKOVA, N. V.; MIKHAILOV, V. V.; UCHIMURA, T. Rheinheimera pacifica sp. nov., a novel halotolerant bacterium isolated from deep sea water of the Pacific. International Journal of Systematic and Evolutionary Microbiology, v. 53, p. 1973-1977, 2003.

ROMANENKO, L.A.; UCHINO, M.; KALINOVSKAYA, N.I.; MIKHAILOV, V.V. Isolation, phylogenetic analysis and screening of marine mollusc-associated bacteria for antimicrobial, hemolytic and surface activities. Microbiological research, v. 163, n. 6, p. 633-644.

ROSELLÓ-MORA, R.; AMANN, R. The species concept for prokaryotes. FEMS Microbiology Reviews, v. 25, p. 36-67, 2001.

ROSZACK, D.B.; COLWELL, R.R. Survival strategies of bacteria in the natural environment. Microbiological and Molecular Biology Reviews, v. 51, n. 3, p. 365-379, 1987.

RUBIN, A. Pesquisa de Vibrio cholerae na água do mar e zooplâncton na região costeira de São Sebastião, Litoral Norte do Estado de São Paulo. Dissertação (Mestrado em Microbiologia) - Instituto de Ciências Biomédicas, Universidade de São Paulo, São Paulo, 2000.

RUDALL, K. M.; KENCHING, W. Chitin System. Biological Reviews of the Cambridge Philosophical Society, v. 48, n. 4, p. 597-605, 1973.

RYAN, R.P.; MONCHY, S.; CARDINALE, M.; TAGHAVI, S.; CROSSMAN, L.; AVISON, M.B.; BERG, G.; van der LELIE, D.; DOW, J.M. The versatility and adaptation of bacteria from the genus Stenotrophomonas. Nature reviews. Microbiology, v. 7, p. 514-525, 2009.

SACKS, D.L.; KAMHAWI, S. Molecular aspects of parasite-vector and vector-host interactions in leishmaniasis. Annual Review of Microbiology, v. 55, p. 453-483, 2001.

SAHAI, A.S.; MANOCHA, M.S. Chitinases of fungi and plants: their involvement in morphogenesis and host-parasite interaction. FEMS Microbiology Reviews, v.11, n. 4, p. 317-338, 1993. 
SAITOU, N.; NEI, M. The neighbor-joining method: a new method for reconstructing phylogenetic trees. Molecular Biology and Evolution, v. 4, p. 406-425, 1987.

SAMBROOK, J.; FRITSCH, E.; MANIATIS, T. Molecular cloning: a laboratory manual. 2. ed. New York: Cold Spring Harbor Laboratory Press, 1989.

SAMPSON, M.N.; GOODAY, G.W. Involvement of chitinases of Bacillus thuringiensis during pathogenesis in insects. Microbiology, v. 144, p.2189-2194, 1998.

SASHIWA, H.; FUJISHIMA, S.; YAMANO, N.; KAWASAKI, N.; NAKAYAMA, A.; MURAKI, M.; HIRAGA, K.; ODA, K.; AIBAA, S. Production of $N$-acetyl-D-glucosamine from alpha-chitin by crude enzymes from Aeromonas hydrophila H-2330. Carbohydrate Research, v. 337, p. 761-763, 2002.

SASSI, R.; KUTNER, M.B. Variação Sazonal do Fitoplâncton da Região do Saco da Ribeira (Lat. $23^{\circ} 30^{\prime} \mathrm{S}$ - Long. $45^{\circ} 06^{\prime} \mathrm{W}$ ), Ubatuba, Brasil. Boletim do Instituto Oceanográfico, v. 31, p. 29-42, 1982.

SEKI, H.; TAGA, N. Microbiological studies on the decomposition of chitin in marine environment. II. Influence of some environmental factors on the growth and activity of marine chitinoclastic bacteria. The Journal of the Oceanographical Society of Japan, v. 19, n. 2, p. 109-111, 1963.

SHAHABUDDIN, M.; KASLOW, D.C. Plasmodium: parasite chitinase and its role in malaria transmission. Experimental Parasitology, v. 79, n. 1, p. 85-88, 1994.

SHAHIDI, F.; ARACHCHI, J. K. V.; JEON, Y. J. Food applications of chitin and chitosans. Trends in Food Science \& Technology, v. 10, p. 37-51, 1999.

SHAKARIAN, A.M.; DWYER, D.M. The Ld Cht1 gene encodes the secretory chitinase of the human pathogen Leishmania donovani. Gene, v. 208, n. 2, p. 315-322, 1998.

SHERR, E.B; SHERR, B.F. Marine microbes: an overview. In: KIRCHMAN, D.L. (Ed.). Microbial ecology of the oceans. New York: Wiley-Liss Press, 2000. p. 13-41.

SHIBATA, T.; SOLO-GABRIELE, H.M.; FLEMING L.E.; ELMIR. S. Monitoring marine recreational water quality using multiple microbial indicators in an urban tropical environment. Water Research, v, 38, n. 13, p. 3119-3131, 2004.

SHIGEMASSA, Y.; SAITO, K.; SASHIWA, H.; SAIMOTO, H. Enzymatic degradation of chitins and partially deacetylated chitins. International Journal of Biological Macromolecules, v. 16, n. 1, p. 43-49. 1994.

SHIMAHARA, K.; TAKIGUCHI, Y. Preparation of crustacean chitin. Methods in Enzymology, v. 161, p. 417-423, 1988.

SHUKLA, B.N.; SINGH, D.V.; SANYAL, S.C. Attachment of non-culturable toxigenic Vibrio cholerae 01 and non-01 and Aeromonas spp. to the aquatic arthropod Gerris spinolae 
and plants in the River Ganga, Varanasi. FEMS Immunology and Medical Microbiology, v. 12, n. 2, p. 113-120, 1995.

SIEFERT, J.L.; LARIOS-SANZ, M.; NAKAMURA, L.K.; SLEPECKY, R.A.; PAUL, J.H.; MOORE, E.R.; FOX, G.E.; JURTSHUK, P. Jr. Phylogeny of marine Bacillus isolates from the Gulf of Mexico. Current Microbiology, v. 41, n. 2, p. 84-44, 2000.

SILVA, L. S. Estudo numérico da circulação e da estrutura termohalina no Canal de São Sebastião. 256 f. Tese (Doutorado em Oceanografia) - Instituto Oceanográfico, Universidade de São Paulo, São Paulo, 2001.

SILVA, M. L. R. B. Avaliação bioquímica da diversidade genética de linhagens de Chromobacterium violaceum e caracterização molecular do gene de quitinase. $166 \mathrm{f}$. Tese (Doutorado em Ciências Biológicas - Microbiologia) - Universidade Federal do Pernambuco, 2007.

SKERRATT, J. H.; BOWMAN, J. P.; NICHOLS, P. D. Shewanella olleyana sp. nov., a marine species isolated from a temperate estuary which produces high levels of polyunsaturated fatty acids. International Journal of Systematic and Evolutionary Microbiology, v. 52, p. 2101-2106, 2002.

SKUJINS, J.J.; POTGIETER, H.J.; ALEXANDER, M. Dissolution of fungal cell walls by a streptomycete chitinase and beta-(1-3) glucanase. Archives of Biochemistry and Biophysics, v. 111, n. 2, p. 358-364, 1965.

SOUZA, K. M. C. Qualidade microbiológica de água de lastro de navios, água e bivalves da região portuária brasileira, com ênfase na detecção de Vibrio cholerae O1. 198 f. Tese (Doutorado em Ciências) - Instituto de ciências Biomédicas, Universidade de São Paulo, São Paulo, 2007.

STEFANIDI, E.; VORGIAS, C.E. Molecular analysis of the gene encoding a new chitinase from the marine psychrophilic bacterium Moritella marina and biochemical characterization of the recombinant enzyme. Extremophiles, v. 12, n. 4, p. 541-552, 2008.

STRAMMA, L.; ENGLAND, M. On the water masses and mean circulation of the South Atlantic Ocean. Journal of Geophysical Research, v. 104, v.9, p. 20863-20883, 1999.

SUGINTA, W. Identification of chitin binding proteins and characterization of two chitinase isoforms from Vibrio alginolyticus 283. Enzyme and Microbial Technology, v. 41, n. 3, p. 212-220, 2007.

SUGINTA, W.; ROBERTSON, P.A.W.; AUSTIN, B.; FRY, S.C.; FOTHERGILLGILMORE, L.A. Chitinases from Vibrio: activity screening and purification of chiA from Vibrio carchariae. Journal of Applied Microbiology, v. 89, p. 76-84, 2000.

SUTRISNO, A.; UEDA, M.; ABE, Y.; NAKAZAWA, M.; MIYATAKE, K. A chitinase with high activity toward partially $\mathrm{N}$-acetylated chitosan from a new, moderately thermophilic, chitin-degrading bacterium, Ralstonia sp. A-471. Applied Microbiology and Biotechnology, v. 63, p. 398-406, 2004. 
SUZUKI, K.; TAIYOJI, M.; SUGAWARA, N.; NIKAIDOU, N.; HENRISSAT, B.; WATANABE, T. The third chitinase gene (chiC) of Serratia marcescens 2170 and the relationship of its product to other bacterial chitinases. The Biochemical Journal, v. 343, p. 587-596, 1999.

SVITIL, A.L.; NÍ CHADHAIN, S.M.; MOORE, J.A.; KIRCHMAN, D.L. Chitin degradation proteins produced by the marine bacterium Vibrio harveyi on different forms of chitin. Applied and Environmental Microbiology, v. 63, n. 2, p. 408-413, 1997.

SZCZUKA, E.; KAZNOWSKI, A. Typing of clinical and environmental Aeromonas sp. strains by random amplified polymorphic DNA PCR, repetitive extragenic palindromic PCR, and enterobacterial repetitive intergenic consensus sequence PCR. Journal of Clinical Microbiology, v. 42, n. 1, p. 220-228, 2004.

TAKAYANAGIA, T.; AJISAKAA, K.; TAKIGUCHIB, Y.; SHIMAHARAB, K. Isolation and characterization of thermostable chitinases from Bacillus licheniformis X-7u. Biochimica et Biophysica Acta, v. 1078, n. 3, p. 404-410, 1991.

TAMPLIN, M.L.; GAUZENS, A.L.; HUQ, A.; SACK, A.; COLWELL, R.R. Attachment of Vibrio cholerae serogroup $\mathrm{O} 1$ to zooplankton and phytoplankton of Bangladesh waters. Applied and Environmental Microbiology, v. 56, n. 6, p. 1977-1989, 1990.

TAMURA, K.; DUDLEY, J.; NEI, M.; KUMAR, S. MEGA 4: molecular evolutionary genetics analysis (MEGA) software version 4.0. Molecular Biology and Evolution, v. 24, p. 1596-1599, 2007.

TANAKA, H.; OGASAWARA, N.; NAKAJIMA, T.; TAMARI, K. Cell walls of Piricularia oryzae. I. Selective enzymolysis of Piricularia oryzae walls by wall-lytic enzymes of Bacillus circulans WL-12. Journal of General and Applied Microbiology, v. 16, p. 39-60, 1970.

TANAKA, T.; FUKUI, T.; IMANAKA, T. Different cleavage specificities of the dual catalytic domains in chitinase from the hyperthermophilic archaeon Thermococcus kodakaraensis KOD1. The Journal of Biological Chemistry, v. 276, n. 38, p. 35629-35635, 2001.

THOMPSON, J. R.; M. F. POLZ. Dynamics of vibrio populations and their role in environmental nutrient cycling, In: THOMPSON, F. L.; AUSTIN, B.; SWINGS, J. (Ed.). The Biology of Vibrios. Washington: ASM Press, DC. 2006. p. 190-203.

TRACEY, M.V. Chitin Review. Pure and Applied Chemistry, v. 7, p. 1-19, 1957.

TSUJIBO, H.; KUBOTA, T.; YAMAMOTO, M.; MIYAMOTO, K.; INAMORI, Y. Characterization of Chitinase Genes from an Alkaliphilic Actinomycete, Nocardiopsis prasina OPC-131. Applied and Environmental Microbiology, v. 69, n. 2, p. 894-900, 2003.

TSUJIBO, H.; ORIKOSHI, H.; TANNO, H.; FUJIMOTO, K.; MIYAMOTO, K.; IMADA, C.; OKAMI, Y.; INAMORI, Y. Cloning, sequence, and expression of a chitinase gene from a marine bacterium, Alteromonas sp. Strain O-7. Journal of Bacteriology, v. 175, n. 1, p. 176$181,1993$. 
UEDA, M.; KOJIMA, M.; YOSHIKAWA, T.; MITSUDA, N.; ARAKI, K.; KAWAGUCHI, T.; MIYATAKE, K.; ARAI, M.; FUKAMIZO, T. A novel type of family 19 chitinase from Aeromonas sp. No.10S-24. Cloning, sequence, expression, and the enzymatic properties. European Journal of Biochemistry, v. 270, n. 11, p. 2513-2520, 2003.

UEDA, M.; OKADA, A.; KAWAGUCHI, T.; ARAI, M. Cloning and Sequence Analysis of a Chitinase Gene (pCA8 ORF) from Aeromonas sp. No. 1OS-24. Journal of Fermentation and Bioengineering, v. 86, n. 6, p. 600-604, 1998

ULHOA, C. Chitinolytic system in Trichoderma harzianum. Tese (Doutorado) - University of Nottingham, Reino Unido, 1991.

UNANUE, M.; AYO, B.; AZUA, L.; BARCINA, I.; IRRIBERRI, J. Temporal variability of attached and free-living bacteria in coastal waters. Microbial Ecology, v. 23, n. 1, p. 27-39, 1992.

UNITED NATIONS. Atlas of Oceans. Disponível em <http://www.oceansatlas.org>. Acesso em 10 de mar. 2008.

URAKAWA, H.; TSUKAMOTO, K. K.; OHWADA, K. Microbial diversity in marine sediments from Sagami Bay and Tokyo Bay, Japan, as determined by $16 \mathrm{~S}$ rRNA gene analysis. Microbiology, v. 145, p. 3305-3315, 1999.

USSERY, D.W.; BINNEWIES, T.T.; GOUVEIA-OLIVEIRA, R.; JARMER, H.; HALLIN, P.F. Genome update: DNA repeats in bacterial genomes. Microbiology, v. 150 p. 3519-3521, 2004.

VAIDYA, R.J.; SHAH, I.M.; VYAS, P.R.; CHHATPAR, H.S. Production of chitinase and its optimization from a novel isolate Alcaligenes xylosoxydans: potential antifungal biocontrol. World Journal of Microbiology and Biotechnology, v. 17, n. 7, p. 62-69, 2001.

Van BELKUM, A.; STRUELENS, M.; De VISSER, A.; VERBRUGH, H.; TIBAYRENE, M. Role of genomic typing in taxonomy, evolutionary genetics and microbial epidemiology. Clinical Microbiology Reviews, v. 14, p. 547-560, 2001

VANDAMME, P.; POT, B.; GILLIS, M.; de VOS, P.; KERSTERS, K.; SWINGS, J. Polyphasic taxonomy, a consensus approach to bacterial systematic. Microbiology and Molecular Biology Reviews, v. 60, p. 407-438, 1996.

VANEECHOUTTE, M.; DE BEENHOUWER, H.; CLAEYS, G.; VERSCHRAEGEN, G.; DE ROUCK, A.; PAEPE, N.; ELAICHOUNI, A.; PORTAELS, F. Identification of Mycobacterium species by using amplified ribosomal DNA restriction analysis. Journal of Clinical Microbiology, v. 31, n. 8, p. 2061-2065, 1993.

VEGA, H.; SPECHT, C. A.; SEMINO, C.E.; ROBBINS, P.W.; EICHINGER, D.; CAPLIVSKI D.; GHOSH, S.; SAMUELSON, J. Cloning and expression of chitinases of Entamoebae. Molecular and Biochemical Parasitology, v. 85, n. 2, p. 139-147, 1997. 
VELASQUEZ, L.; HAMMERSCHMIDT, R. Development of a method for the detection and quantification of total chitinase activity by digital analysis. Journal of Microbiological Methods, v. 59, p. 7-14, 2004.

VENTURINI, N. Influência da quantidade e qualidade da matéria orgânica sedimentar na estrutura e distribuição vertical e horizontal das comunidades bentônicas na plataforma de São Sebastião, São Paulo, Brasil. $230 \mathrm{f}$. Tese (Doutorado em Oceanografia) - Instituto Oceanográfico, Universidade de São Paulo, São Paulo, 2007.

VERSALOVIC, J.; de BRUIJN, F.J.; LUPSKI, J.R. Repetitive sequence-based PCR (repPCR) DNA fingerprinting of bacterial genomes. In: de BRUIJN, F.J.; LUPSKI, J.R.; WEINSTOCK, G.M. (Ed.). Bacterial Genomes: physical structure and analysis. New York: Chapman and Hall, 1998. p. 437-454.

VERSALOVIC, J.; SCHNEIDER, M.; de BRUIJN, F.J.; LUPSKI, J.R. Genomic fingerprinting of bacteria using repetitive sequence-based polymerase chain reaction. Methods in Molecular and Cellular Biology, v. 5, n. 1, p. 25-40, 1994.

VERSALOVIC, J.; KOEUTH, T.; LUPSKI, J.R. Distribution of repetitive DNA sequences in eubacteria and application to fingerprinting of bacterial genomes. Nucleic Acids Research, v. 19, p. 6823-6831, 1991.

VIEIRA, R.P.; GONZALEZ, A.M.; CARDOSO, A.M.; OLIVEIRA, D.N.; ALBANO, R.M.; CLEMENTINO, M.B.M.; MARTINS, O.B.; PARANHOS, R. Relationships between bacterial diversity and environmental variables in a tropical marine environment, Rio de Janeiro. Environmental Microbiology, v. 10, p.189-199, 2008.

VOGAN, C.L.; POWELL, A.; ROWLEY, A.F. Shell disease in crustaceans - just chitin recycling gone wrong? Environmental Microbiology, v. 10, n. 4, p. 826-835, 2008.

VON SPERLING, M. Introdução à qualidade das águas e ao tratamento de esgotos. 2.ed. Belo Horizonte: DESA/UFMG, 1996. p. 243.

VYAS, P.; DESHPANDE, M.V. Enzymatic hydrolysis of chitin by Myrothecium verrucaria chitinase complex and its utilization to produce SCP. The Journal of General and Applied Microbiology, v. 37, n. 3, p. 265-275, 1991.

WANG, S.L.; CHANG, W. Purification and Characterization of two bifunctional Chitinases/Lysozymes Extracellularly produced by Pseudomonas aeruginosa $K-187$ in a shrimp and crab shell powder medium. Applied and Environmental Microbiology, v. 63, n. 2, p. 380-386, 1997.

WANG, S.L.; CHAO, C.H.; LIANG, T.W.; CHEN, C.C. Purification and Characterization of Protease and Chitinase from Bacillus cereus TKU006 and Conversion of Marine Wastes by These Enzymes. Marine Biotechnology, v. 11, p. 334-344, 2009.

WARD, A.C.; BORA, N. Diversity and biogeography of marine actinobacteria. Current Opinion in Microbiology, v. 9, p. 279-286, 2006. 
WATANABE T.; SUZUKI, K.; OYAHAGI, W.; OHNISHI, K.; TANAKA, H. Gene cloning of chitinase A1 from Bacillus circulans WL-12 revealed its evolutionary relationship to Serratia chitinases and to the type III homology units of fibronectin. The Journal of Biological Chemistry, 265, p. 15659-15665, 1990a.

WATANABE, T.; OYANAGI, W.; SUZUKI, K.; TANAKA, H. Chitinase system of Bacillus circulans WL-12 and importance of chitinase A1 in chitin degradation. Journal of Bacteriology, v. 172, n. 7, p. 4017-4022, 1990 b.

WEINSTEIN, J.E.; WEST, T.L.; BRAY, J.T. Shell disease and metal content of blue crabs, Callinectes sapidus, from the Albemarle-Pamlico Estuarine System, North Carolina. Archives of Environmental Contamination and Toxicology, v. 23, n. 3, p. 355-362, 1992.

WEN, C. M.; TSENG, C. S.; CHENG, C. Y.; LI, Y. K. Purification, characterization and cloning of a chitinase from Bacillus sp. NCTU2. Biotechnology and Applied Biochemistry, v. 35, n. 3, p. 213-219, 2002.

WHEELER, D.L.; BARRETT, T.; BENSON, D. A.; BRYANT, S. H.; CANESE, K.; CHURCH, D. M.; DICUCCIO, M.; EDGAR, R.; FEDERHEN, S.; HELMBERG, W.; KENTON, D. L.; KHOVAYKO, O.; LIPMAN, D. J.; MADDEN, T. L.; MAGLOTT, D. R.; OSTELL, J.; PONTIUS, J. U.; PRUITT, K. D.; SCHULER, G. D.; SCHRIML, L. M.; SEQUEIRA, E.; SHERRY, S. T.; SIROTKIN, K.; SOUVOROV, A.; STARCHENKO, G.; SUZEK, T.O.; TATUSOV, R. L.; TATUSOVA, T. A.; WAGNER, L.; YASCHENKO, E. Database resources of the National Center for Biotechnology Information. Nucleic Acids Research, v. 33, p. D39-D45, 2005.

WHITMAN, W.B.; COLEMAN, D.C.; WIEBE, W.J. Prokaryotes: the unseen majority. Proceedings of the National Academy of Sciences, v. 95, p. 6578-6583, 1998.

WILLIAMS, J. G.K.; KUBELIK, A.R.; LIVAK, K.J.; RAFALSKI, J.A.; TINGEY, S. V. DNA polymorphisms amplified by arbitrary primers are useful as genetic markers. Nucleic Acids Research, v. 18, n. 22, p. 6531-6535, 1990.

WILLIAMSON, N.; BRIAN, P.; WELLINGTON, M.H. Molecular detection of bacterial and streptomycete chitinases in the environment. Antonie Leeuwenhoek, v. 78, p. 315-321, 2000.

WILSON, L.A.; SHARP, P.M. Enterobacterial Repetitive Intergenic Consensus (ERIC) Sequences in Escherichia coli: Evolution and Implications for ERIC-PCR. Molecular Biology and Evolution, v. 23, n. 6., p. 1156-1168, 2006.

WOESE, C.R. Bacterial Evolution. Microbiological Reviews, v. 51, n. 2, p. 221-271, 1987.

WOESE, C.R.; KANDLER, O.; WHEELIS, M.L. Towards a natural system of organisms: proposal for the domains Archaea, Bacteria and Eucarya. Proceedings of the National Academy of Sciences of the United States of America, v. 87, p. 4576-4579, 1990.

WOODS, C.R.; VERSALOVIC, J.; KOEUTH, T.; LUPSKI, J.R. Whole-cell repetitive element sequence-based polymerase chain reaction allows rapid assessment of clonal relationships of bacterial isolates. Journal of Clinical Microbiology, v. 31, n. 7, p. 19271931, 1993. 
WU, M.L.; CHUANG, Y.C.; CHEN, J.P.; CHEN, C.S.; CHANG, M.C. Identification and Characterization of the Three Chitin-Binding Domains within the Multidomain Chitinase Chi92 from Aeromonas hydrophila JP101. Applied and Environmental Microbiology, v. 67, n. 11, p. 5100-5106, 2001.

XIAO, X.; YIN, X.; LIN, J.; SUN, L.; YOU, Z.; WANG, P.; WANG, F. Chitinase Genes in Lake Sediments of Ardley Island, Antarctica. Applied and Environmental Microbiology, v. 71, n. 12, p. 7904-7909, 2005.

YABUKI, M.; MIZUSHINA, K.; AMATATSU, T.; ANDO, A.; FUJII, T.; SHIMADA, M.; YAMASHITA, M. Purification and characterization of chitinase and chitobiase produced by Aeromonas hydrophila subsp. Anaerogenes A52. Journal of General and Applied Microbiology, v. 32, n. 1, p. 25-38. 1986.

YAMANOI, T.; TSUTSUMIDA, M.; ODA, Y.; AKAIKE, E.; OSUMI, K.; YAMAMAMOTO, K.; FUJITA, K. Transglycosylation reaction of Mucor hiemalis endo- $\beta$ $\mathrm{N}$-acetylglucosaminidase using sugar derivatives modified at $\mathrm{C}-1$ or $\mathrm{C}-2$ as oligosaccharide acceptors. Carbohydrate Research, v. 339, n. 7, p. 1403-1406, 2004.

YAMAOKA, H.; HAYASHI, H.; KARITA, S.; KIMURA, T.; SAKKA, K.; OHMIYA, K. Purification and some properties of a chitinase from Xanthomonas sp. strain AK. Journal of Bioscience and Bioengineering, v. 88, n. 3, p. 328-330, 1999.

YANG, S. H.; KWON, K. K.; LEE, H. S.; KIM, S. J. Shewanella spongiae sp. nov., isolated from a marine sponge. International Journal of Systematic and Evolutionary Microbiology, v. 56, p. 2879-2882, 2006.

YOON, J.H.; BAE, S.E.; KANG, S.J.; OH, T.K. Rheinheimera aquimaris sp. nov., isolated from seawater of the East Sea in Korea. International Journal of Systematic and Evolutionary Microbiology, v. 57, p. 1386-1390, 2007.

YOON, J.H.; SCHUMANN, P.; KANG, S.J,; JUNG, S.Y.; OH, T.K. Isoptericola dokdonensis sp. nov., isolated from soil. International Journal of Systematic and Evolutionary Microbiology, v. 56, p. 2893-2897, 2006.

ZHANG, Y.Q.; SCHUMANN, P.; LI, W.J.; CHEN, G.Z.; TIAN, X.P.; STACKEBRANDT, E.; XU, L.H.; JIANG, C.L. Isoptericola halotolerans sp. nov., a novel actinobacterium isolated from saline soil from Qinghai Province, north-west China. International Journal of Systematic and Evolutionary Microbiology, v. 55, p. 1867-1870, 2005.

ZHANG, Z.; YUEN, G. Y.; SARATH, G.; PENHEITER, A. R. Chitinases from the plant disease biocontrol agent, Stenotrophomonas maltophilia C3. Phytopathology, v. 91, p. 204$211,2001$.

ZHANG, Z.; YUEN, G. Y.; SARATH, G.; PENHEITER, A. R. Chitinases from plant disease biocontrol agent Stenotrophomonas maltophilia C3. Phytopathology, v. 91, n. 2, p. 204-211, 2001. 
ZHU, Z.; ZHENG, T.; HOMER, R.J.; KIM, Y.; CHEN, N.Y.; COHN, L.; HAMID, Q.; ELIAS, J.A. Acidic Mammalian Chitinase in Asthmatic Th2 Inflammation and IL-13 Pathway Activation. Science, v. 304, n. 5677, p. 1678-1682, 2004.

ZLATKIN, I.V.; SCHNEIDER, M.; de BRUIJN, F. J.; FORNEY, L.J. Diversity among bacteria isolated from the deep subsurface. Journal of Industrial Microbiology, v. 17, p. 219-227, 1996.

ZO, G.; RIVERA, I.N.G.; RUSSEK-COHEN, E; ISLAM, M.S.; SIDDIQUE, A.K.; YUNUS, M.; SACK, R.B; HUQ, A.; COLWELL, R.R. Genomic profiles of clinical and environmental isolates of Vibrio cholerae O1 in cholera endemic areas of Bangladesh. Proceedings of the National Academy of Sciences of the United States of America, v. 99, n. 19, p. 1240912414, 2002.

ZOBELL, C.E. Marine Microbiology. USA: Chronica Botanica Co, Waltham, Mass, 1946, p. 240.

ZOBELL, C.E.; RITTENBERG, S.C. The occurrence and characteristics of chitinoclastics bacteria in the sea. Journal of Bacteriology, v. 35, n. 3, p. 275-287, 1938. 
ANEXO I - Bactérias quitinolíticas isoladas de amostras de água do mar do Canal de São Sebastião, Baixada Santista e Ubatuba.

\begin{tabular}{|c|c|c|c|c|c|c|c|c|c|c|c|c|}
\hline $\mathbf{N}^{\circ}$ & Local & $\begin{array}{l}\text { Data da } \\
\text { Coleta }\end{array}$ & $\begin{array}{c}\text { Data de } \\
\text { acesso } \\
\text { (RDP) } \\
\end{array}$ & $\begin{array}{l}\mathbf{N}^{\circ} \text { de Acesso } \\
\text { (RDP) }\end{array}$ & Identificação pelo RDP & $\begin{array}{c}\text { Similari } \\
\text { dade } \\
\text { (RDP) }\end{array}$ & $\begin{array}{c}\mathbf{N}^{\circ} \mathrm{de} \\
\mathbf{p b}\end{array}$ & $\begin{array}{l}\text { Halo } \\
(\mathbf{m m})\end{array}$ & GlcNAc & \begin{tabular}{|c|}
$\beta-N-$ \\
acetil- \\
glicosa \\
minidase \\
\end{tabular} & $\begin{array}{c}\text { Quito- } \\
\text { biosidase }\end{array}$ & $\begin{array}{c}\text { Endo- } \\
\text { quitinase }\end{array}$ \\
\hline $\mathrm{CH} 01$ & São Sebastião & $22 / 08 / 05$ & $27 / 04 / 09$ & EF527850.1 & Micromonospora sp. 161113 & $99 \%$ & 589 & 2,21 & 0,00 & 0,032 & & \\
\hline $\mathrm{CH} 03$ & São Sebastião & $19 / 09 / 05$ & $27 / 04 / 09$ & X83799 & Cellulomas flavigena $(\mathrm{T}) \mathrm{DSM} 20109 \mathrm{~T}$ & $100 \%$ & 549 & 1,55 & 0,00 & 0,010 & & \\
\hline $\mathrm{CH} 04$ & São Sebastião & $19 / 09 / 05$ & $27 / 04 / 09$ & X83803 & Cellulomonas fimi DSM20113T & $100 \%$ & 549 & 2,25 & 0,00 & 0,00 & & \\
\hline $\mathrm{CHO5}_{2}$ & São Sebastião & $19 / 09 / 05$ & $27 / 04 / 09$ & Y09656 & Cellulomonas sp. 794 & $99,5 \%$ & 505 & 3,62 & 0,12 & 0,010 & & \\
\hline $\mathrm{CHO7}_{\mathrm{T}}$ & São Sebastião & $19 / 09 / 05$ & $27 / 04 / 09$ & X74683 & Aeromonas sobria ATCC43979T & $100 \%$ & 541 & 4,13 & 0,00 & 1,074 & & \\
\hline $\mathrm{CH} 08$ & São Sebastião & $19 / 09 / 05$ & $27 / 04 / 09$ & X74683 & Aeromonas sobria ATCC43979T & $100 \%$ & 541 & 2,30 & 0,25 & 0,181 & & \\
\hline CH18 & São Sebastião & $19 / 09 / 05$ & $27 / 04 / 09$ & X74683 & Aeromonas sobria ATCC43979T & $100 \%$ & 541 & 3,46 & 0,89 & 1,132 & & \\
\hline CH19 & São Sebastião & $19 / 09 / 05$ & $27 / 04 / 09$ & AY212737 & uncultured bacterium; 42ds5; & $99 \%$ & 566 & 2,30 & 2,10 & 0,001 & & \\
\hline $\mathrm{CH} 29$ & São Sebastião & $19 / 09 / 05$ & $27 / 04 / 09$ & AY439226 & Paenibacillus sp. GIC16 & $100 \%$ & 539 & 2,66 & 0,00 & 0,043 & & \\
\hline $\mathrm{CH} 50_{\mathrm{B}}$ & São Sebastião & $17 / 10 / 05$ & $27 / 04 / 09$ & AJ297946 & Serratia marcescens $\mathrm{HO} 1-\mathrm{A}$ & $100 \%$ & 548 & 2,78 & 0,53 & 0,381 & & \\
\hline CH53 & São Sebastião & $17 / 10 / 05$ & $27 / 04 / 09$ & AY439226 & Paenibacillus sp. GIC16 & $100 \%$ & 539 & 2,66 & 0,00 & 0,027 & & \\
\hline CH54 & São Sebastião & $17 / 10 / 05$ & $27 / 04 / 09$ & AJ297946 & Serratia marcescens $\mathrm{HO} 1-\mathrm{A}$ & $100 \%$ & 548 & 2,44 & 0,00 & 0,018 & & \\
\hline $\mathrm{CH}_{5} 4_{1}$ & São Sebastião & $17 / 10 / 05$ & $27 / 04 / 09$ & X74683 & Aeromonas sobria ATCC43979T & $100 \%$ & 541 & 3,35 & 0,00 & 0,034 & & \\
\hline CH58 & São Sebastião & $17 / 10 / 05$ & $27 / 04 / 09$ & AY439226 & Paenibacillus sp. GIC16 & $100 \%$ & 539 & 1,43 & 0,00 & 0,015 & & \\
\hline CH59 & São Sebastião & $05 / 12 / 05$ & $27 / 04 / 09$ & AF290545 & Bacillus thuringiensis (T) ATCC 10792 & $100 \%$ & 590 & 1,12 & 0,00 & 0,013 & & \\
\hline $\mathrm{CH} 60$ & São Sebastião & $05 / 12 / 05$ & $27 / 04 / 09$ & AM162343 & Paenibacillus sp. JS10-07 & $100 \%$ & 539 & 4,14 & 0,00 & 0,00 & & \\
\hline $\mathrm{CH} 72$ & São Sebastião & $24 / 01 / 06$ & $27 / 04 / 09$ & DQ522106 & Paenibacillus sp. UXO5-11 & $99 \%$ & 539 & 2,51 & 0,00 & 0,006 & & \\
\hline $\mathrm{CH} 81$ & São Sebastião & $24 / 01 / 06$ & $27 / 04 / 09$ & DQ522106 & Paenibacillus sp. UXO5-11 & $99 \%$ & 539 & 0,71 & 0,00 & 0,005 & & \\
\hline CH82 & São Sebastião & $24 / 01 / 06$ & $27 / 04 / 09$ & AY439226 & Paenibacillus sp. GIC16 & $100 \%$ & 539 & 4,83 & 0,00 & 0,014 & & \\
\hline $\mathrm{CH} 98_{\mathrm{T}}$ & São Sebastião & $24 / 01 / 06$ & $27 / 04 / 09$ & X74683 & Aeromonas sobria ATCC43979T & $100 \%$ & 541 & 5,21 & 0,42 & 0,044 & & \\
\hline CH101 & São Sebastião & $13 / 02 / 06$ & $27 / 04 / 09$ & X74683 & Aeromonas sobria ATCC43979T & $100 \%$ & 541 & 6,10 & 7,29 & 0,878 & 0,844 & 1,059 \\
\hline $\mathrm{CH} 102_{\mathrm{B}}$ & São Sebastião & $13 / 02 / 06$ & $27 / 04 / 09$ & X74683 & Aeromonas sobria ATCC43979T & $100 \%$ & 541 & 5,36 & 0,28 & 0,122 & & \\
\hline $\mathrm{CH} 104_{\mathrm{B}}$ & São Sebastião & $13 / 02 / 06$ & $27 / 04 / 09$ & X74683 & Aeromonas sobria ATCC43979T & $100 \%$ & 541 & 4,89 & 0,00 & 0,569 & & \\
\hline $\mathrm{CH} 125$ & Santos & $17 / 02 / 06$ & $27 / 04 / 09$ & X74683 & Aeromonas sobria ATCC43979T & $100 \%$ & 541 & 1,62 & 7,39 & 2,030 & 0,865 & 0,829 \\
\hline
\end{tabular}

(continua) 
ANEXO I - Bactérias quitinolíticas isoladas de amostras de água do mar do Canal de São Sebastião, Baixada Santista e Ubatuba.

\begin{tabular}{|c|c|c|c|c|c|c|c|c|c|c|c|c|}
\hline $\mathbf{N}^{\circ}$ & Local & $\begin{array}{c}\text { Data da } \\
\text { Coleta }\end{array}$ & $\begin{array}{l}\text { Data de } \\
\text { acesso } \\
\text { (RDP) }\end{array}$ & $\begin{array}{l}\mathbf{N}^{\mathbf{o}} \text { de Acesso } \\
\text { (RDP) }\end{array}$ & Identificação pelo RDP & $\begin{array}{l}\text { Similari } \\
\text { dade } \\
\text { (RDP) }\end{array}$ & $\begin{array}{c}N^{o} \text { de } \\
\text { pb }\end{array}$ & $\begin{array}{l}\text { Halo } \\
(\mathbf{m m})\end{array}$ & GlcNAc & $\begin{array}{c}\beta-N- \\
\text { acetyl- } \\
\text { glicosa } \\
\text { minidase }\end{array}$ & $\begin{array}{c}\text { Quito- } \\
\text { biosidase }\end{array}$ & $\begin{array}{c}\text { Endo- } \\
\text { quitinase }\end{array}$ \\
\hline $\mathrm{CH} 127_{\mathrm{B}}$ & Santos & $17 / 02 / 06$ & $27 / 04 / 09$ & X74683 & Aeromonas sobria ATCC43979T & $100 \%$ & 541 & 2,37 & 0,00 & 0,451 & & \\
\hline CH131 & Santos & $17 / 02 / 06$ & $27 / 04 / 09$ & AY518675.1 & Paenibacillus sp. tjsxy2003-e-4 & $100 \%$ & 539 & 3,76 & 0,00 & 0,010 & & \\
\hline $\mathrm{CH} 133$ & Santos & $17 / 02 / 06$ & $27 / 04 / 09$ & X74683 & Aeromonas sobria ATCC43979T & $100 \%$ & 541 & 4,27 & 5,36 & 0,653 & 0,00 & 0,00 \\
\hline $\mathrm{CH} 145$ & Santos & $17 / 02 / 06$ & $27 / 04 / 09$ & X74683 & Aeromonas sobria ATCC43979T & $100 \%$ & 541 & 4,84 & 3,59 & 0,153 & & \\
\hline $\mathrm{CH} 150_{\mathrm{B}}$ & Santos & $17 / 02 / 06$ & $27 / 04 / 09$ & X74683 & Aeromonas sobria ATCC43979T & $100 \%$ & 541 & 2,58 & 7,63 & 1,067 & 0,857 & 0,686 \\
\hline $\mathrm{CH} 152$ & Santos & $17 / 02 / 06$ & $27 / 04 / 09$ & X74683 & Aeromonas sobria ATCC43979T & $100 \%$ & 541 & 1,89 & 0,00 & 0,512 & & \\
\hline $\mathrm{CH} 176$ & São Sebastião & 21/03/06 & $27 / 04 / 09$ & EF212893 & Paenibacillus provencensis strain 4401170 & $100 \%$ & 539 & 1,80 & 0,00 & 0,00 & & \\
\hline CH179 & São Sebastião & $21 / 03 / 06$ & $27 / 04 / 09$ & AB008509 & Stenotrophomonas maltophilia ATCC 13637T & $99 \%$ & 545 & 0,41 & 0,00 & 0,015 & & \\
\hline CH178 & Ubatuba & $21 / 03 / 06$ & $27 / 04 / 09$ & $\mathrm{X} 74683$ & Aeromonas sobria ATCC43979T & $100 \%$ & 541 & 1,79 & 0,00 & 0,001 & & \\
\hline $\mathrm{CH} 188$ & Santos & $29 / 03 / 06$ & $27 / 04 / 09$ & X74683 & Aeromonas sobria ATCC43979T & $100 \%$ & 541 & 3,08 & 2,86 & 0,574 & & \\
\hline CH193 & Santos & $29 / 03 / 06$ & $27 / 04 / 09$ & X74683 & Aeromonas sobria ATCC43979T & $100 \%$ & 541 & 4,39 & 0,00 & 0,043 & & \\
\hline $\mathrm{CH} 200$ & Santos & 29/03/06 & $27 / 04 / 09$ & X74683 & Aeromonas sobria ATCC43979T & $100 \%$ & 541 & 0,79 & 0,00 & 0,041 & & \\
\hline $\mathrm{CH} 211$ & Santos & $27 / 04 / 06$ & $27 / 04 / 09$ & X92631 & Micromonospora rosaria $(\mathrm{T})$ DSM 803 & $97,6 \%$ & 589 & 6,84 & 0,06 & 0,014 & & \\
\hline $\mathrm{CH} 218$ & Santos & $27 / 04 / 06$ & $27 / 04 / 09$ & X74683 & Aeromonas sobria ATCC43979T & $100 \%$ & 541 & 4,83 & 3,26 & 0,609 & & \\
\hline $\mathrm{CH} 224_{\mathrm{R}}$ & Santos & $27 / 04 / 06$ & $27 / 04 / 09$ & AJ297946 & Serratia marcescens HO1-A & $100 \%$ & 548 & 2,34 & 1,88 & 0,716 & & \\
\hline $\mathrm{CH} 227$ & Santos & 01/06/06 & $27 / 04 / 09$ & AF290545 & Bacillus thuringiensis (T) ATCC 10792 & $100 \%$ & 590 & 1,09 & 0,00 & 0,016 & & \\
\hline $\mathrm{CH} 228$ & Santos & 01/06/06 & $27 / 04 / 09$ & X74683 & Aeromonas sobria ATCC43979T & $100 \%$ & 541 & 2,23 & 0,00 & 0,00 & & \\
\hline $\mathrm{CH} 232$ & Santos & 01/06/06 & $27 / 04 / 09$ & X74683 & Aeromonas sobria ATCC43979T & $100 \%$ & 541 & 6,04 & 6,53 & 0,107 & 0,671 & 0,408 \\
\hline $\mathrm{CH} 234$ & Santos & $01 / 06 / 06$ & $27 / 04 / 09$ & X74683 & Aeromonas sobria ATCC43979T & $98 \%$ & 541 & 3,80 & 0,15 & 0,015 & & \\
\hline $\mathrm{CH} 235$ & Santos & 01/06/06 & $27 / 04 / 09$ & X74683 & Aeromonas sobria ATCC43979T & $100 \%$ & 541 & 2,29 & 1,25 & 0,021 & & \\
\hline $\mathrm{CH} 236_{\mathrm{T}}$ & Santos & 01/06/06 & $27 / 04 / 09$ & X74683 & Aeromonas sobria ATCC43979T & $100 \%$ & 541 & 4,09 & 2,90 & 0,098 & & \\
\hline $\mathrm{CH} 241$ & São Sebastião & $30 / 05 / 06$ & $27 / 04 / 09$ & AB367437 & Glycomyces mongolensis 26c & $97,5 \%$ & 571 & 4,30 & 0,00 & 0,074 & & \\
\hline $\mathrm{CH} 251$ & São Sebastião & $21 / 11 / 06$ & $27 / 04 / 09$ & AB110498 & Dyella japonica XD53 & $100 \%$ & 581 & 2,08 & 0,00 & 0,031 & & \\
\hline
\end{tabular}


ANEXO I - Bactérias quitinolíticas isoladas de amostras de água do mar do Canal de São Sebastião, Baixada Santista e Ubatuba.

\begin{tabular}{|c|c|c|c|c|c|c|c|c|c|c|c|c|}
\hline $\mathbf{N}^{\mathbf{o}}$ & Local & $\begin{array}{l}\text { Data da } \\
\text { Coleta }\end{array}$ & $\begin{array}{l}\text { Data de } \\
\text { acesso } \\
\text { (RDP) }\end{array}$ & $\begin{array}{c}\mathbf{N}^{0} \text { de Acesso } \\
\text { (RDP) }\end{array}$ & Identificação pelo RDP & $\begin{array}{c}\text { Similari } \\
\text { dade } \\
\text { (RDP) }\end{array}$ & $\begin{array}{c}\mathbf{N}^{o} \text { de } \\
\text { pb }\end{array}$ & $\begin{array}{l}\text { Halo } \\
(\mathbf{m m})\end{array}$ & GIcNAc & $\begin{array}{c}\beta-N- \\
\text { acetyl- } \\
\text { glicosa } \\
\text { minidase }\end{array}$ & $\begin{array}{c}\text { Quito- } \\
\text { biosidase }\end{array}$ & $\begin{array}{c}\text { Endo- } \\
\text { quitinase }\end{array}$ \\
\hline $\mathrm{CH} 256$ & São Sebastião & $21 / 11 / 06$ & $27 / 04 / 09$ & AB110498 & Dyella japonica XD53 & $100 \%$ & 581 & 2,58 & 0,00 & 0,025 & & \\
\hline $\mathrm{CH} 260$ & São Sebastião & $14 / 12 / 06$ & $27 / 04 / 09$ & X92619 & Micromonospora fulvoviolacea DSM 43905 & $100 \%$ & 589 & 4,11 & 0,00 & 0,048 & & \\
\hline $\mathrm{CH} 261$ & São Sebastião & $14 / 12 / 06$ & $27 / 04 / 09$ & X92619 & Micromonospora fulvoviolacea DSM 43905 & $100 \%$ & 589 & 2,68 & 0,00 & 0,287 & & \\
\hline $\mathrm{CH} 266$ & Santos & $24 / 01 / 07$ & $27 / 04 / 09$ & X74683 & Aeromonas sobria ATCC43979T & $100 \%$ & 541 & 5,31 & 1,40 & 0,141 & & \\
\hline $\mathrm{CH} 267$ & Santos & $24 / 01 / 07$ & $27 / 04 / 09$ & AB198337 & Paenibacillus sp. HC1 & $98 \%$ & 539 & 6,72 & 1,34 & 0,011 & 0,360 & 0,062 \\
\hline $\mathrm{CH} 269$ & Santos & $24 / 01 / 07$ & $27 / 04 / 09$ & X74726 & Vibrio vulnificus ATCC275627 & $98 \%$ & 552 & 2,26 & 0,00 & 0,035 & & \\
\hline $\mathrm{CH} 274_{\mathrm{B}}$ & Santos & $24 / 01 / 07$ & $27 / 04 / 09$ & X74683 & Aeromonas sobria ATCC43979T & $100 \%$ & 541 & 4,15 & 2,58 & 0,187 & & \\
\hline $\mathrm{CH} 274_{\mathrm{T}}$ & Santos & $24 / 01 / 07$ & $27 / 04 / 09$ & X74683 & Aeromonas sobria ATCC43979T & $100 \%$ & 541 & 4,00 & 7,83 & 0,169 & 0,785 & 0,720 \\
\hline $\mathrm{CH} 275$ & Santos & $24 / 01 / 07$ & $27 / 04 / 09$ & EU249554 & Isoptericola variable DPBS7 & $99,7 \%$ & 475 & 2,02 & 0,00 & 0,001 & & \\
\hline $\mathrm{CH} 286$ & Santos & $24 / 01 / 07$ & $27 / 04 / 09$ & X74683 & Aeromonas sobria ATCC43979T & $100 \%$ & 541 & 6,91 & 7,77 & 0,535 & 1,231 & 1,252 \\
\hline CH296 & Santos & $24 / 01 / 07$ & $27 / 04 / 09$ & X74683 & Aeromonas sobria ATCC43979T & $100 \%$ & 541 & 3,75 & 2,36 & 0,064 & & \\
\hline $\mathrm{CH} 297$ & Santos & $24 / 01 / 07$ & $27 / 04 / 09$ & X74683 & Aeromonas sobria ATCC43979T & $100 \%$ & 541 & 4,16 & 0,00 & 0,056 & & \\
\hline $\mathrm{CH} 298_{\mathrm{T}}$ & Santos & $24 / 01 / 07$ & $27 / 04 / 09$ & X74683 & Aeromonas sobria ATCC43979T & $100 \%$ & 541 & 5,33 & 0,56 & 0,177 & & \\
\hline $\mathrm{CH} 302$ & Santos & $24 / 01 / 07$ & $27 / 04 / 09$ & X74683 & Aeromonas sobria ATCC43979T & $100 \%$ & 541 & 5,97 & 5,02 & 0,079 & 0,494 & 0,350 \\
\hline $\mathrm{CH} 314_{\mathrm{T}}$ & Santos & $13 / 02 / 07$ & $27 / 04 / 09$ & X74683 & Aeromonas sobria ATCC43979T & $100 \%$ & 541 & 5,80 & 8,81 & 0,178 & 1,625 & 1,362 \\
\hline $\mathrm{CH} 316$ & São Sebastião & $13 / 02 / 07$ & $27 / 04 / 09$ & AB008509 & Stenotrophomonas maltophilia ATCC 13637T & $99 \%$ & 545 & 1,47 & 0,00 & 0,003 & & \\
\hline CH322 & São Sebastião & $13 / 02 / 07$ & $27 / 04 / 09$ & X79450 & Sanguibacter keddieii $(\mathrm{T}) \mathrm{ST74}$ & $97,8 \%$ & 580 & 2,05 & 0,00 & 0,073 & & \\
\hline $\mathrm{CH} 324$ & Santos & $13 / 02 / 07$ & $27 / 04 / 09$ & AB030583 & Pseudomonas alcaliphila AL15-20 & $98 \%$ & 476 & 1,73 & 0,00 & 0,048 & & \\
\hline $\mathrm{CH} 327$ & Santos & $13 / 02 / 07$ & $27 / 04 / 09$ & X74683 & Aeromonas sobria ATCC43979T & $100 \%$ & 541 & 2,94 & 4,43 & 0,153 & & \\
\hline $\mathrm{CH} 341_{\mathrm{T}}$ & Santos & $13 / 02 / 07$ & $27 / 04 / 09$ & X74683 & Aeromonas sobria ATCC43979T & $100 \%$ & 541 & 3,58 & 0,00 & 0,060 & & \\
\hline $\mathrm{CH} 343_{\mathrm{B}}$ & Santos & $13 / 02 / 07$ & $27 / 04 / 09$ & X74683 & Aeromonas sobria ATCC43979T & $100 \%$ & 541 & 4,65 & 0,00 & 0,016 & & \\
\hline $\mathrm{CH} 343_{\mathrm{T}}$ & Santos & $13 / 02 / 07$ & $27 / 04 / 09$ & X74683 & Aeromonas sobria ATCC43979T & $100 \%$ & 541 & 5,04 & 1,95 & 0,134 & & \\
\hline $\mathrm{CH} 344$ & Santos & $13 / 02 / 07$ & $27 / 04 / 09$ & X74683 & Aeromonas sobria ATCC43979T & $100 \%$ & 541 & 4,98 & 0,07 & 0,049 & & \\
\hline CH349 & Santos & $13 / 02 / 07$ & $27 / 04 / 09$ & X74683 & Aeromonas sobria ATCC 43979T & $100 \%$ & 541 & 1,85 & 0,73 & 0,058 & & \\
\hline
\end{tabular}

(continua) 
ANEXO I - Bactérias quitinolíticas isoladas de amostras de água do mar do Canal de São Sebastião, Baixada Santista e Ubatuba.

\begin{tabular}{|c|c|c|c|c|c|c|c|c|c|c|c|c|}
\hline $\mathbf{N}^{\mathbf{o}}$ & Local & $\begin{array}{c}\text { Data da } \\
\text { Coleta }\end{array}$ & $\begin{array}{c}\text { Data de } \\
\text { acesso } \\
\text { (RDP) }\end{array}$ & $\begin{array}{c}\mathbf{N}^{\circ} \text { de Acesso } \\
\text { (RDP) }\end{array}$ & Identificação pelo RDP & $\begin{array}{c}\text { Similari } \\
\text { dade } \\
(\text { RDP })\end{array}$ & $\begin{array}{l}\mathbf{N}^{\mathbf{o}} \mathrm{de} \\
\mathbf{p b}\end{array}$ & $\begin{array}{l}\text { Halo } \\
(\mathbf{m m})\end{array}$ & GlcNAc & $\begin{array}{c}\beta-N- \\
\text { acetyl- } \\
\text { glicosa } \\
\text { minidase }\end{array}$ & $\begin{array}{c}\text { Quito- } \\
\text { biosidase }\end{array}$ & $\begin{array}{l}\text { Endo- } \\
\text { quitinase }\end{array}$ \\
\hline $\mathrm{CH} 351_{\mathrm{B}}$ & Santos & $13 / 02 / 07$ & $27 / 04 / 09$ & X74683 & Aeromonas sobria ATCC 43979T & $100 \%$ & 541 & 5,68 & 0,00 & 0,056 & & \\
\hline $\mathrm{CH} 353_{\mathrm{T}}$ & Santos & $14 / 02 / 07$ & $27 / 04 / 09$ & X74683 & Aeromonas sobria ATCC43979T & $100 \%$ & 541 & 4,26 & 1,79 & 0,447 & & \\
\hline $\mathrm{CH} 362_{\mathrm{B}}$ & Santos & $13 / 02 / 07$ & $27 / 04 / 09$ & X74683 & Aeromonas sobria ATCC43979T & $100 \%$ & 541 & 5,13 & 0,00 & 0,102 & & \\
\hline $\mathrm{CH} 366$ & Santos & 27/03/07 & $27 / 04 / 09$ & X74683 & Aeromonas sobria ATCC43979T & $100 \%$ & 541 & 6,12 & 7,11 & 0,198 & 0,861 & 0,805 \\
\hline CH368 & Santos & 27/03/07 & $27 / 04 / 09$ & X74695 & Vibrio cholerae $(\mathrm{T})$; ATCC $14035 \mathrm{~T}$ & $99 \%$ & 537 & 4,41 & 0,00 & 0,012 & & \\
\hline $\mathrm{CH} 372$ & Santos & 27/03/07 & $27 / 04 / 09$ & AF361784 & Streptomyces luridiscabiei S63 & $100 \%$ & 559 & 3,20 & 0,00 & 0,087 & & \\
\hline $\mathrm{CH} 374$ & Santos & $27 / 03 / 07$ & $27 / 04 / 09$ & AY323610 & Paenibacillus timonensis (T) 2301032 & $99 \%$ & 539 & 3,39 & 0,00 & 0,00 & & \\
\hline $\mathrm{CH} 375$ & Santos & $27 / 03 / 07$ & $27 / 04 / 09$ & AY323611 & Paenibacillus timonensis (T) 2301033 & $99 \%$ & 539 & 2,82 & 0,00 & 0,010 & & \\
\hline
\end{tabular}


ANEXO II - Bactérias quitinolíticas isoladas de amostras plâncton do mar do Canal de São Sebastião, Baixada Santista e Ubatuba.

\begin{tabular}{|c|c|c|c|c|c|c|c|c|c|c|c|c|}
\hline $\mathbf{N}^{\circ}$ & Local & $\begin{array}{c}\text { Data da } \\
\text { Coleta }\end{array}$ & $\begin{array}{c}\text { Data de } \\
\text { acesso } \\
\text { (RDP) } \\
\end{array}$ & $\begin{array}{l}\mathbf{N}^{o} \text { de Acesso } \\
\text { (RDP) }\end{array}$ & Identificação pelo RDP & $\begin{array}{c}\text { Similari } \\
\text { dade } \\
\text { (RDP) }\end{array}$ & $\begin{array}{c}\mathbf{N}^{\mathbf{o}} \mathrm{de} \\
\mathbf{p b}\end{array}$ & $\begin{array}{l}\text { Halo } \\
(\mathbf{m m})\end{array}$ & GIcNAc & $\begin{array}{c}\beta-N- \\
\text { acetyl- } \\
\text { glicosa } \\
\text { minidase } \\
\end{array}$ & $\begin{array}{c}\text { Quito- } \\
\text { biosidase }\end{array}$ & $\begin{array}{c}\text { Endo- } \\
\text { quitinase }\end{array}$ \\
\hline CHZ01 & Ubatuba & $21 / 03 / 06$ & $27 / 04 / 09$ & AJ006104 & Pseudomonas stutzeri ATCC 17598 & $100 \%$ & 430 & 2,41 & 0,00 & 0,00 & & \\
\hline CHZ03 & Ubatuba & $21 / 03 / 06$ & $27 / 04 / 09$ & AF273082 & Pseudoxanthomonas mexicana AMX 26B & $100 \%$ & 480 & 3,59 & 0,00 & 0,017 & & \\
\hline $\mathrm{CHZ04}$ & Ubatuba & $21 / 03 / 06$ & $27 / 04 / 09$ & EU075218 & Stenotrophomonas sp. DCY33 & $100 \%$ & 474 & 1,30 & 0,00 & 0,00 & & \\
\hline CHZ16 & Ubatuba & $21 / 03 / 06$ & $27 / 04 / 09$ & AB008509 & Stenotrophomonas maltophilia ATCC $13637 \mathrm{~T}$ & $99 \%$ & 474 & 0,90 & 0,00 & 0,00 & & \\
\hline $\mathrm{CHZ21} 1_{\mathrm{B}}$ & Santos & $29 / 03 / 06$ & $27 / 04 / 09$ & X74683 & Aeromonas sobria ATCC43979T & $100 \%$ & 436 & 3,21 & 0,27 & 0,008 & & \\
\hline CHZ24 & Santos & 29/03/06 & $27 / 04 / 09$ & X74683 & Aeromonas sobria ATCC43979T & $100 \%$ & 436 & 4,56 & 1,40 & 0,120 & & \\
\hline CHZ26 & Santos & 29/03/06 & $27 / 04 / 09$ & AF290545 & Bacillus thuringiensis (T) ATCC 10792 & $100 \%$ & 449 & 1,30 & 0,00 & 0,016 & & \\
\hline CHZ37 & Santos & $27 / 04 / 06$ & 27/04/09 & X74683 & Aeromonas sobria ATCC43979T & $100 \%$ & 436 & 2,90 & 0,04 & 0,207 & & \\
\hline CHZ39 & Santos & $27 / 04 / 06$ & $27 / 04 / 09$ & X74683 & Aeromonas sobria ATCC43979T & $100 \%$ & 436 & 2,61 & 0,00 & 0,00 & & \\
\hline CHZ42 & Santos & $27 / 04 / 06$ & $27 / 04 / 09$ & X74683 & Aeromonas sobria ATCC43979T & $100 \%$ & 436 & 5,05 & 0,00 & 0,00 & & \\
\hline $\mathrm{CHZ44}$ & Santos & $27 / 04 / 06$ & $27 / 04 / 09$ & DQ899897 & Uncultured bacterium clone G2DMC-101 & $98 \%$ & 475 & 1,57 & 0,00 & 0,062 & & \\
\hline CHZ45 & São Sebastião & $30 / 05 / 06$ & $27 / 04 / 09$ & X82133 & Shewanella putrefaciens (T) ATTCC 8071 & $99 \%$ & 437 & 1,69 & 0,00 & 0,021 & & \\
\hline $\mathrm{CHZ47}$ & São Sebastião & $30 / 05 / 06$ & $27 / 04 / 09$ & AJ297946 & Serratia marcescens HO1-A & $100 \%$ & 469 & 3,88 & 0,00 & 0,017 & & \\
\hline CHZ49 & Santos & 01/06/06 & $27 / 04 / 09$ & X74683 & Aeromonas sobria ATCC43979T & $100 \%$ & 436 & 4,10 & 0,39 & 0,020 & & \\
\hline CHZ52 & Santos & 01/06/06 & $27 / 04 / 09$ & X74683 & Aeromonas sobria ATCC43979T & $100 \%$ & 436 & 2,82 & 7,90 & 0,804 & 0,823 & 0,912 \\
\hline CHZ54 & Santos & 01/06/06 & $27 / 04 / 09$ & X74683 & Aeromonas sobria ATCC43979T & $100 \%$ & 436 & 2,53 & 0,84 & 0,163 & & \\
\hline CHZ57 & Ubatuba & $30 / 05 / 06$ & $27 / 04 / 09$ & AY439226 & Paenibacillus sp. GIC16 & $100 \%$ & 453 & 2,88 & 0,00 & 0,00 & & \\
\hline CHZ67 & São Sebastião & $24 / 01 / 06$ & $27 / 04 / 09$ & AB008509 & Stenotrophomonas maltophilia ATCC $13637 \mathrm{~T}$ & $99 \%$ & 474 & 1,66 & 0,00 & 0,004 & & \\
\hline $\mathrm{CHZ75}_{1}$ & São Sebastião & $24 / 01 / 06$ & $27 / 04 / 09$ & AM183347 & Rheinheimera perlucida BA131T & $96 \%$ & 433 & 2,27 & 0,00 & 0,030 & & \\
\hline CHZ76 & São Sebastião & $24 / 01 / 06$ & $27 / 04 / 09$ & AJ297946 & Serratia marcescens HO1-A & $100 \%$ & 469 & 2,51 & 0,00 & 0,00 & & \\
\hline CHZ79 & São Sebastião & $24 / 01 / 06$ & $27 / 04 / 09$ & AJ297946 & Serratia marcescens HO1-A & $100 \%$ & 469 & 3,30 & 0,00 & 0,029 & & \\
\hline CHZ84 & São Sebastião & $24 / 01 / 06$ & $27 / 04 / 09$ & AJ297946 & Serratia marcescens HO1-A & $100 \%$ & 469 & 1,78 & 0,83 & 0,086 & & \\
\hline CHZ87 & São Sebastião & $13 / 02 / 06$ & $27 / 04 / 09$ & AB008509 & Stenotrophomonas maltophilia ATCC $13637 \mathrm{~T}$ & $99 \%$ & 474 & 0,98 & 0,00 & 0,001 & & \\
\hline
\end{tabular}

(continua) 
ANEXO II - Bactérias quitinolíticas isoladas de amostras plâncton do mar do Canal de São Sebastião, Baixada Santista e Ubatuba.

\begin{tabular}{|c|c|c|c|c|c|c|c|c|c|c|c|c|}
\hline $\mathbf{N}^{\mathbf{o}}$ & Local & $\begin{array}{l}\text { Data da } \\
\text { Coleta }\end{array}$ & $\begin{array}{l}\text { Data de } \\
\text { acesso } \\
\text { (RDP) }\end{array}$ & $\begin{array}{c}\mathbf{N}^{\circ} \text { de Acesso } \\
\text { (RDP) }\end{array}$ & Identificação pelo RDP & $\begin{array}{c}\text { Similari } \\
\text { dade } \\
\text { (RDP) }\end{array}$ & $\begin{array}{c}\mathbf{N}^{\circ} \text { de } \\
\text { pb }\end{array}$ & $\begin{array}{l}\text { Halo } \\
(\mathbf{m m})\end{array}$ & GlcNAc & $\begin{array}{c}\beta-N- \\
\text { acetyl- } \\
\text { glicosa } \\
\text { minidase }\end{array}$ & $\begin{array}{c}\text { Quito- } \\
\text { biosidase }\end{array}$ & $\begin{array}{c}\text { Endo- } \\
\text { quitinase }\end{array}$ \\
\hline CHZ92 & Santos & $17 / 02 / 06$ & $27 / 04 / 09$ & EF212893 & Paenibacillus provencensis strain 4401170 & $100 \%$ & 454 & 1,68 & 0,00 & 0,00 & & \\
\hline $\mathrm{CHZ100}$ & São Sebastião & $21 / 06 / 06$ & $27 / 04 / 09$ & X74683 & Aeromonas sobria ATCC43979T & $100 \%$ & 436 & 0,53 & 0,00 & 0,00 & & \\
\hline CHZ107 & São Sebastião & $21 / 06 / 06$ & $27 / 04 / 09$ & X74683 & Aeromonas sobria ATCC43979T & $100 \%$ & 436 & 3,19 & 0,37 & 0,032 & & \\
\hline $\mathrm{CHZ109}_{\mathrm{T}}$ & São Sebastião & $18 / 07 / 06$ & $27 / 04 / 09$ & X74683 & Aeromonas sobria ATCC43979T & $100 \%$ & 436 & 6,49 & 6,80 & 0,191 & 0,652 & 0,504 \\
\hline CHZ116 & São Sebastião & $18 / 07 / 06$ & $27 / 04 / 09$ & AF290545 & Bacillus thuringiensis (T) ATCC 10792 & $100 \%$ & 449 & 0,82 & 0,00 & 0,00 & & \\
\hline CHZ118 & São Sebastião & $18 / 07 / 06$ & $27 / 04 / 09$ & X74683 & Aeromonas sobria ATCC43979T & $100 \%$ & 436 & 3,01 & 1,14 & 0,448 & & \\
\hline $\mathrm{CHZ}_{127}$ & São Sebastião & $22 / 08 / 06$ & $27 / 04 / 09$ & X74684 & Aeromonas sobria ATCC43979T & $100 \%$ & 436 & 2,03 & 0,62 & 0,294 & & \\
\hline $\mathrm{CHZ}_{127}$ & São Sebastião & $18 / 07 / 06$ & $27 / 04 / 09$ & X74683 & Aeromonas sobria ATCC43979T & $100 \%$ & 436 & 2,22 & 1,34 & 0,287 & & \\
\hline CHZ131 & São Sebastião & $19 / 09 / 06$ & $27 / 04 / 09$ & AF290545 & Bacillus thuringiensis (T) ATCC 10792 & $100 \%$ & 449 & 1,94 & 0,00 & 0,00 & & \\
\hline $\mathrm{CHZ139}_{\mathrm{B}}$ & São Sebastião & $24 / 10 / 06$ & $27 / 04 / 09$ & X83803 & Cellulomonas fimi DSM20113T & $100 \%$ & 463 & 1,89 & 0,00 & 0,023 & & \\
\hline $\mathrm{CHZ139}_{\mathrm{T}}$ & São Sebastião & $24 / 10 / 06$ & $27 / 04 / 09$ & X74683 & Aeromonas sobria ATCC43979T & $100 \%$ & 436 & 3,04 & 0,00 & 0,076 & & \\
\hline $\mathrm{CHZ}_{140}$ & São Sebastião & $24 / 10 / 06$ & $27 / 04 / 09$ & X83803 & Cellulomonas fimi DSM20113T & $100 \%$ & 463 & 3,12 & 0,00 & 0,00 & & \\
\hline CHZ141 & São Sebastião & $24 / 10 / 06$ & $27 / 04 / 09$ & X83803 & Cellulomonas fimi DSM20113T & $100 \%$ & 463 & 1,89 & 0,00 & 0,00 & & \\
\hline CHZ142 & São Sebastião & $24 / 10 / 06$ & $27 / 04 / 09$ & X92595 & Micromonospora echinospora DSM43036 & $100 \%$ & 494 & 2,57 & 0,00 & 0,00 & & \\
\hline CHZ143 & São Sebastião & $24 / 10 / 06$ & $27 / 04 / 09$ & X74683 & Aeromonas sobria ATCC43979T & $100 \%$ & 436 & 3,08 & 0,00 & 0,312 & & \\
\hline CHZ150 & São Sebastião & $21 / 11 / 06$ & $27 / 04 / 09$ & EF690415.1 & Paenibacillus amylolyticus M18-5 & $99 \%$ & 453 & 1,69 & 0,00 & 0,00 & & \\
\hline CHZ156 & São Sebastião & $21 / 11 / 06$ & $27 / 04 / 09$ & $\mathrm{AB} 023354$ & Cellulosimicrobium cellulans IFO15013 & $100 \%$ & 498 & 0,88 & 0,00 & 0,046 & & \\
\hline CHZ162 & São Sebastião & $14 / 12 / 06$ & $27 / 04 / 09$ & X74683 & Aeromonas sobria ATCC43979T & $100 \%$ & 436 & 1,17 & 0,00 & 0,008 & & \\
\hline CHZ165 & São Sebastião & $14 / 12 / 06$ & $27 / 04 / 09$ & X67036 & Ralstonia solanacearum $(\mathrm{T}) ;$ ATCC 11696 & $100 \%$ & $100 \%$ & 3,85 & 0,00 & 0,099 & & \\
\hline CHZ166 & São Sebastião & $23 / 01 / 07$ & $27 / 04 / 09$ & AJ297946 & Serratia marcescens $\mathrm{HO} 1-\mathrm{A}$ & $100 \%$ & 469 & 2,61 & 0,00 & 0,033 & & \\
\hline CHZ171 & São Sebastião & $23 / 01 / 07$ & $27 / 04 / 09$ & AJ399485 & Streptomyces arenae ISP5293 & $100 \%$ & 492 & 1,54 & 0,00 & 0,101 & & \\
\hline CHZ181 & Ubatuba & $23 / 01 / 07$ & $27 / 04 / 09$ & X74683 & Aeromonas sobria ATCC43979T & $100 \%$ & 436 & 3,78 & 0,52 & 0,299 & & \\
\hline CHZ184 & Ubatuba & $23 / 01 / 07$ & $27 / 04 / 09$ & AJ006104 & Pseudomonas stutzeri ATCC 17598 & $100 \%$ & 430 & 1,43 & 0,00 & 0,024 & & \\
\hline CHZ186 & Santos & $24 / 01 / 07$ & $27 / 04 / 09$ & X74683 & Aeromonas sobria ATCC43979T & $100 \%$ & 436 & 4,45 & 1,05 & 0,121 & & \\
\hline
\end{tabular}

(continua) 
ANEXO II - Bactérias quitinolíticas isoladas de amostras plâncton do mar do Canal de São Sebastião, Baixada Santista e Ubatuba.

\begin{tabular}{|c|c|c|c|c|c|c|c|c|c|c|c|c|}
\hline $\mathbf{N}^{\mathbf{o}}$ & Local & $\begin{array}{c}\text { Data da } \\
\text { Coleta }\end{array}$ & $\begin{array}{l}\text { Data de } \\
\text { acesso } \\
\text { (RDP) }\end{array}$ & $\begin{array}{l}N^{0} \text { de Acesso } \\
\text { (RDP) }\end{array}$ & Identificação pelo RDP & $\begin{array}{l}\text { Similari } \\
\text { dade } \\
\text { (RDP) }\end{array}$ & $\begin{array}{c}N^{0} \text { de } \\
\text { pb }\end{array}$ & $\begin{array}{l}\text { Halo } \\
(\mathbf{m m})\end{array}$ & GlcNAc & $\begin{array}{c}\beta-N- \\
\text { acetyl- } \\
\text { glicosa } \\
\text { minidase }\end{array}$ & $\begin{array}{c}\text { Quito- } \\
\text { biosidase }\end{array}$ & $\begin{array}{c}\text { Endo- } \\
\text { quitinase }\end{array}$ \\
\hline CHZ197 & Santos & $24 / 01 / 07$ & $27 / 04 / 09$ & X74683 & Aeromonas sobria ATCC43979T & $100 \%$ & 436 & 4,66 & 0,00 & 0,049 & & \\
\hline CHZ200 & Santos & 24/01/07 & $27 / 04 / 09$ & $\mathrm{X} 74683$ & Aeromonas sobria ATCC43979T & $100 \%$ & 436 & 5,39 & 0,05 & 0,401 & & \\
\hline CHZ202 & Santos & 24/01/07 & 27/04/09 & X74683 & Aeromonas sobria ATCC43979T & $97 \%$ & 420 & 4,79 & 0,00 & 0,190 & & \\
\hline CHZ208 & Santos & $24 / 01 / 07$ & $27 / 04 / 09$ & X74683 & Aeromonas sobria ATCC43979T & $100 \%$ & 436 & 5,47 & 0,00 & 0,00 & & \\
\hline CHZ212 & São Sebastião & 23/01/07 & $27 / 04 / 09$ & AJ297946 & Serratia marcescens HO1-A & $100 \%$ & 469 & 4,96 & 0,00 & 0,019 & & \\
\hline $\mathrm{CHZ220}$ & São Sebastião & 23/01/07 & 27/04/09 & AB008509 & Stenotrophomonas maltophilia ATCC 13637T & $99 \%$ & 474 & 1,53 & 0,00 & 0,00 & & \\
\hline CHZ223 & Santos & $13 / 02 / 07$ & $27 / 04 / 09$ & X74683 & Aeromonas sobria ATCC43979T & $98 \%$ & 436 & 2,29 & 2,70 & 0,567 & 0,281 & 0,020 \\
\hline $\mathrm{CHZ}_{22} 4_{\mathrm{B}}$ & Santos & $13 / 02 / 07$ & $27 / 04 / 09$ & $\mathrm{X} 74683$ & Aeromonas sobria ATCC43979T & $100 \%$ & 436 & 1,75 & 0,07 & 0,00 & & \\
\hline $\mathrm{CHZ224}_{\mathrm{T}}$ & Santos & $13 / 02 / 07$ & $27 / 04 / 09$ & X74683 & Aeromonas sobria ATCC43979T & $100 \%$ & 436 & 3,12 & 0,25 & 0,031 & & \\
\hline CHZ232 & Santos & $13 / 02 / 07$ & $27 / 04 / 09$ & $\mathrm{X} 74683$ & Aeromonas sobria ATCC43979T & $100 \%$ & 436 & 3,98 & 0,75 & 0,147 & & \\
\hline $\mathrm{CHZ}_{233_{\mathrm{B}}}$ & São Sebastião & $13 / 02 / 07$ & $27 / 04 / 09$ & AM906086 & Paenibacillus sp. P33 & $99 \%$ & 453 & 2,21 & 0,00 & 0,00 & & \\
\hline CHZ234 & São Sebastião & $13 / 02 / 07$ & $27 / 04 / 09$ & AJ006104 & Pseudomonas stutzeri ATCC 17598 & $100 \%$ & 430 & 2,66 & 0,00 & 0,019 & & \\
\hline CHZ236 & São Sebastião & $13 / 02 / 07$ & $27 / 04 / 09$ & $\mathrm{AB} 023354$ & Cellulosimicrobium cellulans IFO15013 & $100 \%$ & 498 & 1,36 & 0,00 & 0,069 & & \\
\hline CHZ239 & Santos & $13 / 02 / 07$ & $27 / 04 / 09$ & AY167820.1 & Paenibacillus pasadenensis strain SAFN-007 & $99 \%$ & 453 & 1,40 & 0,00 & 0,00 & & \\
\hline CHZ240 & Santos & $13 / 02 / 07$ & $27 / 04 / 09$ & X74683 & Aeromonas sobria ATCC43979T & $100 \%$ & 436 & 5,76 & 0,35 & 0,055 & 0,00 & 0,00 \\
\hline CHZ248 & Ubatuba & $13 / 02 / 07$ & $27 / 04 / 09$ & AJ781355 & Streptomyces nojiriensis LMG 20094; & $98 \%$ & 492 & 1,20 & 0,00 & 0,072 & & \\
\hline CHZ253 & Santos & $13 / 02 / 07$ & 27/04/09 & AY439226 & Paenibacillus sp. GIC16 & $100 \%$ & 453 & 2,77 & 0,00 & 0,009 & & \\
\hline CHZ254 & São Sebastião & $13 / 02 / 07$ & $27 / 04 / 09$ & EF028080 & Paenibacillus curdlanolyticus MP-1 & $96 \%$ & 453 & 1,77 & 0,00 & 0,00 & & \\
\hline CHZ257 & Ubatuba & 13/02/07 & $27 / 04 / 09$ & AB045095 & Bacillus sp. HSCC 1474 & $97 \%$ & 460 & 2,70 & 0,00 & 0,00 & & \\
\hline CHZ274 & São Sebastião & $16 / 03 / 07$ & 27/04/09 & AY439226 & Paenibacillus sp. GIC16 & $100 \%$ & 453 & 4,68 & 0,00 & 0,021 & & \\
\hline CHZ276 & São Sebastião & $16 / 03 / 07$ & $27 / 04 / 09$ & AJ781357 & Streptomyces mutomycini LMG20098 & $99 \%$ & 490 & 1,31 & 0,00 & 0,00 & & \\
\hline CHZ289 & São Sebastião & $16 / 03 / 07$ & $27 / 04 / 09$ & AB008509 & Stenotrophomonas maltophilia ATCC 13637T & $99 \%$ & 474 & 1,20 & 0,00 & 0,018 & & \\
\hline CHZ294 & Ubatuba & $16 / 03 / 07$ & $27 / 04 / 09$ & EU239193 & Stenotrophomonas sp. KNUC283 & $99 \%$ & 474 & 4,59 & 0,00 & 0,00 & & \\
\hline CHZ298 & Ubatuba & $16 / 03 / 07$ & $27 / 04 / 09$ & EU239193 & Stenotrophomonas sp. KNUC283 & $99 \%$ & 474 & 2,62 & 0,00 & 0,00 & & \\
\hline
\end{tabular}

(continua) 
ANEXO II - Bactérias quitinolíticas isoladas de amostras plâncton do mar do Canal de São Sebastião, Baixada Santista e Ubatuba.

\begin{tabular}{|c|c|c|c|c|c|c|c|c|c|c|c|c|}
\hline $\mathbf{N}^{\mathbf{o}}$ & Local & $\begin{array}{l}\text { Data da } \\
\text { Coleta }\end{array}$ & $\begin{array}{l}\text { Data de } \\
\text { acesso } \\
\text { (RDP) }\end{array}$ & $\begin{array}{c}\mathbf{N}^{\circ} \text { de Acesso } \\
\text { (RDP) }\end{array}$ & Identificação pelo RDP & $\begin{array}{c}\text { Similari } \\
\text { dade } \\
\text { (RDP) }\end{array}$ & $\begin{array}{c}\mathbf{N}^{\circ} \mathrm{de} \\
\mathbf{p b}\end{array}$ & $\begin{array}{l}\text { Halo } \\
(\mathbf{m m})\end{array}$ & GIcNAc & $\begin{array}{c}\beta-N- \\
\text { acetyl- } \\
\text { glicosa } \\
\text { minidase }\end{array}$ & $\begin{array}{c}\text { Quito- } \\
\text { biosidase }\end{array}$ & $\begin{array}{c}\text { Endo- } \\
\text { quitinase }\end{array}$ \\
\hline CHZ299 & Ubatuba & $16 / 03 / 07$ & $27 / 04 / 09$ & X95922 & Xanthomonas populi LMG5743-T & $99 \%$ & 481 & 5,24 & 0,00 & 0,00 & & \\
\hline CHZ304 & Santos & $27 / 03 / 07$ & $27 / 04 / 09$ & X74683 & Aeromonas sobria ATCC43979T & $100 \%$ & 436 & 4,07 & 0,56 & 0,422 & & \\
\hline CHZ305 & Santos & $27 / 03 / 07$ & $27 / 04 / 09$ & X74683 & Aeromonas sobria ATCC43979T & $100 \%$ & 436 & 1,98 & 1,36 & 0,099 & & \\
\hline CHZ306 & Santos & $27 / 03 / 07$ & $27 / 04 / 09$ & X74683 & Aeromonas sobria ATCC43979T & $100 \%$ & 436 & 2,68 & 7,80 & 0,411 & 1,421 & 1,120 \\
\hline CHZ308 & Santos & $27 / 03 / 07$ & $27 / 04 / 09$ & X74683 & Aeromonas sobria ATCC43979T & $98 \%$ & 436 & 1,58 & 0,00 & 0,042 & & \\
\hline CHZ310 & Santos & $27 / 03 / 07$ & $27 / 04 / 09$ & X74683 & Aeromonas sobria ATCC43979T & $100 \%$ & 436 & 1,69 & 0,00 & 0,026 & & \\
\hline CHZ312 & Santos & $27 / 03 / 07$ & $27 / 04 / 09$ & X74683 & Aeromonas sobria ATCC43979T & $100 \%$ & 436 & 4,96 & 0,85 & 0,033 & & \\
\hline CHZ313 & Santos & $27 / 03 / 07$ & $27 / 04 / 09$ & X74683 & Aeromonas sobria ATCC43979T & $100 \%$ & 436 & 1,11 & 0,00 & 0,00 & & \\
\hline CHZ318 & Santos & $27 / 03 / 07$ & $27 / 04 / 09$ & X74683 & Aeromonas sobria ATCC43979T & $100 \%$ & 436 & 5,88 & 6,20 & 0,085 & 1,051 & 0,806 \\
\hline CHZ319 & Santos & $27 / 03 / 07$ & $27 / 04 / 09$ & X74683 & Aeromonas sobria ATCC43979T & $97 \%$ & 420 & 5,13 & 0,00 & 0,042 & & \\
\hline CHZ320 & Santos & $27 / 03 / 07$ & $27 / 04 / 09$ & X74683 & Aeromonas sobria ATCC43979T & $100 \%$ & 436 & 1,94 & 0,00 & 0,103 & & \\
\hline CHZ324 & Santos & $27 / 03 / 07$ & $27 / 04 / 09$ & EF513610 & Bacillus cereus M2 & $97 \%$ & 412 & 2,29 & 0,00 & 0,00 & & \\
\hline CHZ327 & Santos & $27 / 03 / 07$ & $27 / 04 / 09$ & AF290545 & Bacillus thuringiensis (T) ATCC 10792 & $100 \%$ & 449 & 2,94 & 0,00 & 0,003 & & \\
\hline CHZ329 & Santos & $27 / 03 / 07$ & $27 / 04 / 09$ & X74683 & Aeromonas sobria ATCC43979T & $100 \%$ & 436 & 2,04 & 1,75 & 0,327 & & \\
\hline CHZ339 & Santos & $27 / 03 / 07$ & $27 / 04 / 09$ & X74683 & Aeromonas sobria ATCC43979T & $100 \%$ & 436 & 4,89 & 0,00 & 0,049 & & \\
\hline CHZ342 & Santos & $27 / 03 / 07$ & $27 / 04 / 09$ & AF290545 & Bacillus thuringiensis (T) ATCC 10792 & $100 \%$ & 449 & 3,89 & 0,00 & 0,018 & & \\
\hline
\end{tabular}

